
Fabiane dos Santos

(Organizadora)

\title{
Meio Ambiente em Foco Volume 13
}

\author{
1a Edição
}

Belo Horizonte

Poisson

2021 
Editor Chefe: Dr. Darly Fernando Andrade

\section{Conselho Editorial}

Dr. Antônio Artur de Souza - Universidade Federal de Minas Gerais Msc. Davilson Eduardo Andrade

Dra. Elizângela de Jesus Oliveira - Universidade Federal do Amazonas

Msc. Fabiane dos Santos

Dr. José Eduardo Ferreira Lopes - Universidade Federal de Uberlândia

Dr. Otaviano Francisco Neves - Pontifícia Universidade Católica de Minas Gerais

Dr. Luiz Cláudio de Lima - Universidade FUMEC

Dr. Nelson Ferreira Filho - Faculdades Kennedy

Msc. Valdiney Alves de Oliveira - Universidade Federal de Uberlândia

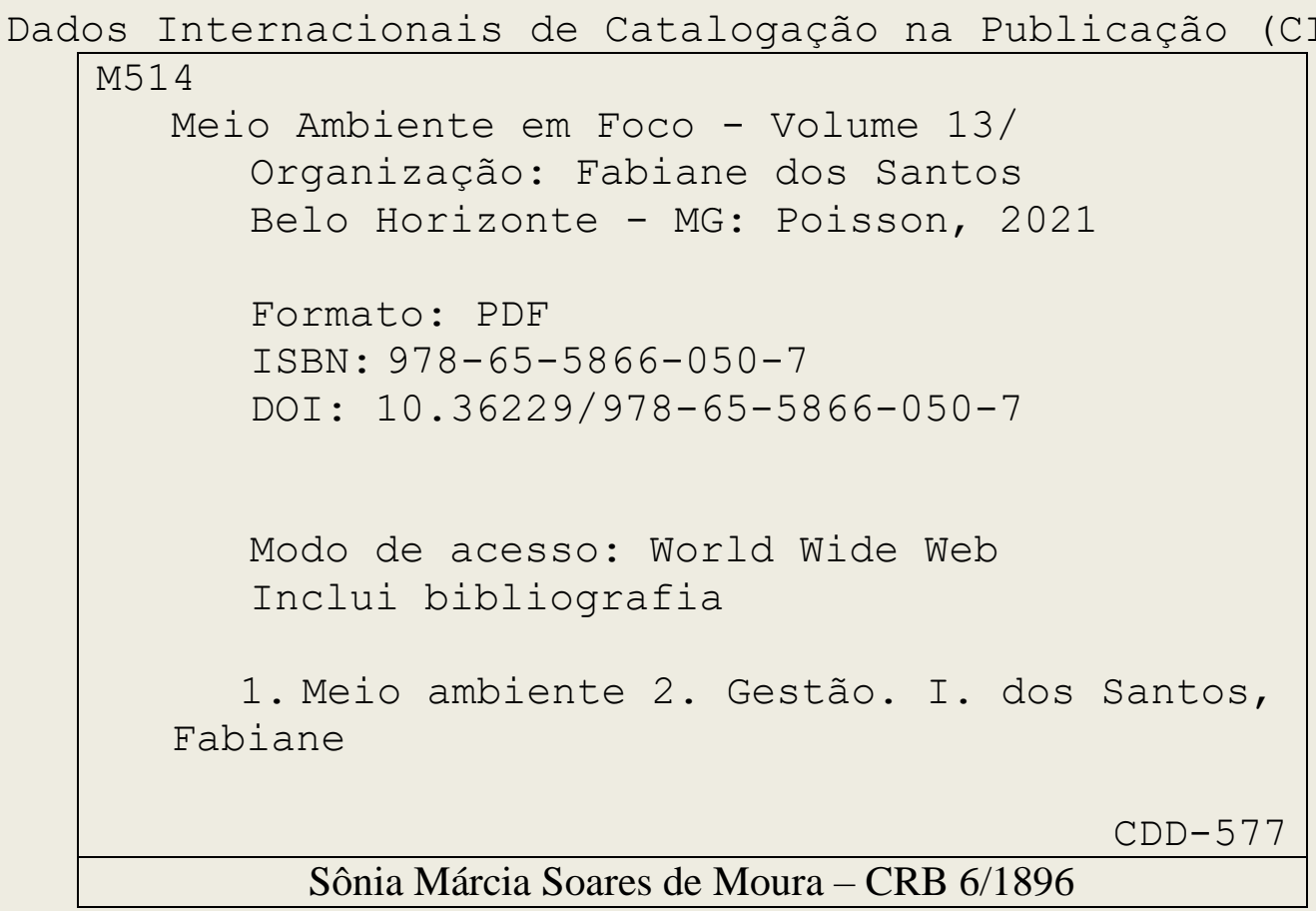

O conteúdo dos artigos e seus dados em sua forma, correção e confiabilidade são de responsabilidade exclusiva dos seus respectivos autores.

Baixe outros títulos gratuitamente em www.poisson.com.br contato@poisson.com.br 


\section{APRESENTAÇÃO}

Há uma exigência imperiosa em ligarmos as relações humanas com as bases da sustentabilidade para a vida em nosso planeta. Ressignificar, no sentido de atribuir o que se conhece à nossa visão sobre o meio do qual somos integrantes, é um dos caminhos para a percepção ambiental mais eficiente e ativa em prol da educação e da qualidade de vida que constitui a essência de qualquer ser vivo. Para tal, requer-se mudar as perspectivas e alterar os resultados, além das escolhas e dos comportamentos.

Formar entendimento e conectar o ser humano com o meio ambiente apazigua e restaura os valores, as escolhas e as atitudes ambientais, transformando a sociedade e a cultura além das necessidades. É com esse viés que se pode chegar à tomada de consciência e às mudanças significativas.

Ao ampliarmos os conhecimentos e levá-los adiante cumprimos com o desafio de coordenar a riqueza ambiental do país de forma mais equitativa e descentralizada, assegurando a reflexão e o debate com justiça socioambiental. Desenvolvendo, portanto, a clareza do papel de cada um nesse processo.

Alinhar ao que o caro leitor espera, surpreendê-lo e estimulá-lo a compartilhar com o maior número de pessoas, desde estudantes, profissionais, a tomadores de decisões, se propaga nas próximas páginas, recheadas de bons conteúdos, comprometimento dos autores e amplas vias de conhecimento.

Aproveite a leitura!

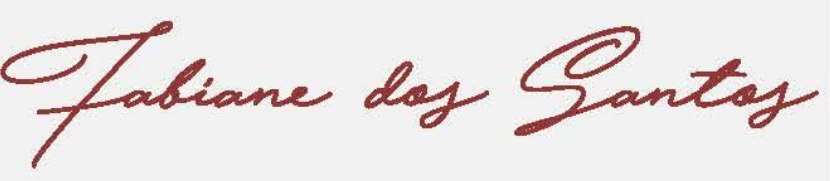




\section{SUMÁRIO}

Capítulo 1: 0 papel das Unidades de Conservação na educação ambiental por meio do uso público 09

Aline Aparecida Pereira

DOI: 10.36229/978-65-5866-050-7.CAP.01

Capítulo 2: Análise da Participação Social voltada para a Educação Ambiental 12

Letícia Paschoaletto Dias, Jane Margaret Costa de Frontin Werneck

DOI: $10.36229 / 978-65-5866-050-7 . C A P .02$

Capítulo 3: A mobilização social em questões ambientais no Paraná: 0 caso da APA da Escarpa Devoniana e o Projeto de Lei 527/2016 20

Lia Maris Orth Ritter Antiqueira, Katya Cristina de Lima Picanço, Danislei Bertoni

DOI: 10.36229/978-65-5866-050-7.CAP.03

Capítulo 4: Evolução temporal do uso e ocupação do solo no município de Teixeira de Freitas, Bahia. 29

Emilly da Silva Farias, Joscélia Monteiro Santos de Brito, Raquel Viana Quinelato, João Batista Lopes da Silva, Laylane Pinheiro Alves

DOI: $10.36229 / 978-65-5866-050-7 . C A P .04$

Capítulo 5: Biopirataria: Impacto socioambiental no Brasil. 33 Amanda Cerqueira dos Santos, Eduarda Cristina Da Vinha, Mayara dos Santos Pereira, Wilton Silva de Souza, Bárbara Maria Borges Ribeiro

DOI: $10.36229 / 978-65-5866-050-7 . C A P .05$

Capítulo 6: A proteção dos animais no ordenamento Jurídico Brasileiro 38 Graciela Flávia Hack, Ozana Rodrigues Boritza, Camila Ferreira Ribeiro DOI: 10.36229/978-65-5866-050-7.CAP.06

Capítulo 7: Agroecologia em prosa virtual: Uma extensão universitária possível no contexto de pandemia 42 Maria Luiza Andrade de Farias Aires, Gabrielle Custódio Melo, Luciano Majolo, Shirleyde Alves dos Santos DOI: 10.36229/978-65-5866-050-7.CAP.07 


\section{SUMÁRIO}

Capítulo 8: A compostagem como prática pedagógica para a efetivação da educação ambiental no ambiente escolar: Uma revisão de literatura.

Benedito Aparecido de Castro, Francisco Giovani Souza Laércio, Lincoln de Souza Lopes, Thiago José

Pimenta Alves, Letícia Rodrigues da Fonseca

DOI: $10.36229 / 978-65-5866-050-7 . C A P .08$

Capítulo 9: Compostagem da cama de aviário após recria de poedeiras 58

Karoll Andrea Alfonso Torres-Cordido, Fernanda Gomes Linhares, João Pedro de Barros Reicao Cordido, Caroline Campelo da Silva Ribeiro, Guilherme Ribeiro, Pedro Cassuce Brandão

DOI: 10.36229/978-65-5866-050-7.CAP.09

Capítulo 10: Caracterização de cinza de casca como precursor de sílica 67

Paula Irigon de Irigon, Mirian Dosolina Fuzinatto, Pedro José Sanches Filho, Lucas Bonan Gomes, Amanda Ramos Pauletto

DOI: $10.36229 / 978-65-5866-050-7 . C A P .10$

Capítulo 11: Uso das cinzas de casca de arroz para obtenção de sílica pelo processo solgel

Mirian Dosolina Fuzinatto, Paula Irigon de Irigon, Pedro José Sanches Filho

DOI: 10.36229/978-65-5866-050-7.CAP.11

Capítulo 12: Tratamento de efluentes das indústrias têxteis: Revisão de literatura ..81

Gabriel Oliveira Roque, Yuri Fernando Dubbern, Victor José dos Santos Baldan, Bárbara Maria Borges Ribeiro

DOI: $10.36229 / 978-65-5866-050-7 . C A P .12$

Capítulo 13: Influência de condições operacionais no processo de pervaporação aplicado a efluentes têxteis sintéticos com corantes reativo 86

Gabriela Simon, Miriam Albara, Rita de Cássia Siqueira Curto Valle, Ricardo Antonio Francisco Machado, Cintia Marangoni

DOI: 10.36229/978-65-5866-050-7.CAP.13 


\section{SUMÁRIO}

Capítulo 14: Resíduos sólidos domesticos em Comunidades Rurais: A realidade da Escola Municipal Ângelo Ricardo em Frutal - MG. 92

Eliana Gomes de Paula e Silva, Aline Nunes de Souza, Lidiane Aparecida Alves, Adriano Reis de Paula e Silva, Fábio Rodrigues da Silva

DOI: $10.36229 / 978-65-5866-050-7 . C A P .14$

Capítulo 15: Estudo da composição gravimétrica de resíduos sólidos produzidos pelo restaurante da Universidade Federal de Viçosa - Campus Florestal 96

Brenda Silva Soares, Laiane Ferreira da Silva, Matheus Morais de Souza, Hygor Aristides Victor Rossoni DOI: $10.36229 / 978-65-5866-050-7 . C A P .15$

Capítulo 16: Os poluentes e a toxicidade dos rejeitos de mineração de ferro: Efeitos do rompimento das barragens em Mariana e Brumadinho - MG 100

Jocimara Camargo da Silva, Carolina Carneiro de Freitas Scaquetti, Leonardo Granziera, Renata Kelly Mendes, Regina Marcia Longo

DOI: $10.36229 / 978-65-5866-050-7 . C A P .16$

Capítulo 17: Avaliação da erodibilidade de solos na área urbana de João Monlevade MG 103

Maísa Comar Pinhotti Aguiar, Jean Aparecido Viegas

DOI: $10.36229 / 978-65-5866-050-7 . C A P .17$

Capítulo 18: Análise de risco e susceptibilidade a erosão com auxílio do Sensoriamento Remoto 110

Diogo Caio Rocha Amorim, Abílio Silva Nunes, Eula Paula Oliveira Silva, Guilherme Coelho Araujo, Jhenifer Stefany Eloi de Paulo, Lorena Lopes Gonçalves

DOI: $10.36229 / 978-65-5866-050-7 . C A P .18$

Capítulo 19: Construção de uma matriz de ponderação para análise integrada dos aspectos e impactos ambientais em parque eólico 123

Lucidalva Rodrigues de Souza Nogueira, Admilson Írio Ribeiro, Gerson Araújo de Medeiros

DOI: $10.36229 / 978-65-5866-050-7 . C A P .19$ 


\section{SUMÁRIO}

Capítulo 20: Avaliação técnica visual das condições fitossanitárias das árvores do centro a do município de Governador Valadares-MG 127

Rafael Teixeira Coelho, Maria Luiza de Melo Vieira, Marlon Campos Coelho

DOI: 10.36229/978-65-5866-050-7.CAP.20

Capítulo 21: Produção de flores e frutos de Bertholletia excelsa em ambientes florestais e desmatados do Noroeste do Pará, Brasil 131

Amauri José Pereira, Susan Aragón Carrasco, Troy Patrick Beldini, Ricardo Scoles

DOI: $10.36229 / 978-65-5866-050-7 . C A P .21$

Capítulo 22: Diagnóstico do nível de pressão sonora no núcleo urbano do município de Capanema - PA. 146

Mateus Lopes Moreira, Thais Gleice Martins Braga, Eduarda Randel Guimarães Souza, Ricardo Cunha de Oliveira, Evellem Vitória de Souza Freitas, Igor de Souza Gomide

DOI: $10.36229 / 978-65-5866-050-7 . C A P .22$

Autores: 


\section{Capítulo 1}

\section{O papel das Unidades de Conservação na educação ambiental por meio do uso público}

\section{Aline Aparecida Pereira}

Resumo: 0 papel de uma Unidade de Conservação (UC) não se resume apenas em conservar áreas legalmente delimitadas com rica biodiversidade silvestre e, incentivar o extrativismo sustentável pelas populações locais. Sua atuação está muito além desses limitantes geográficos. Um dos objetivos das UCs é a educação ambiental, que ocorre por meio de palestra e práticas educativas de grande interação homem-natureza. 0 uso público é uma das formas de propiciar esta educação, e tende a agregar não apenas o conhecimento, mas também, o despertar para o ambiental. Essa prática de visitação e recreação nessas unidades é de fundamental importância também para a preservação do local, pois, inibe a caça ilegal, a invasão e o desmatamento da área além, de qualquer outro comportamento ilícito que acarrete em intensos impactos negativos. A educação ambiental atual tem engatinhado para alcançar a eficiência, estando legalmente presente nos currículos escolares, mas, por ser um processo contínuo e, que envolve o despertar intrínseco do ser humano, essa estratégia adotada nem sempre funciona. A vivência em meio a ambientes silvestres proporcionado pelas UCs, atrelado a educação ambiental acumulada e, a praticada durante a visitação, possibilita o alcance de uma grande eficácia no processo, pois trabalha a sensibilidade do visitante durante o processo de interpretação ambiental gerada pelo contato com a natureza. Com isso, a educação ambiental tem maiores possibilidades de atingir seus objetivos fundamentais além de despertar na sociedade, o seu pertencimento no natural e aumentar os envolvimentos em causas de caráter ambientais e socioambientais.

Palavras chave: Educação Ambiental; Visitação; Unidade de Conservação; Sensibilidade Ambiental. 


\section{INTRODUÇ̃̃O}

As Unidades de Conservação (UC) desempenham um grande papel para a conservação do patrimônio biológico. Segundo BRASIL (2012), as UCs são espaços territoriais, com características naturais relevantes em termos de biodiversidade e beleza cênica, que assegurar amostras ecologicamente significativas e viáveis das diferentes populações, habitat e ecossistemas do território nacional e das águas jurisdicionais. De acordo com BRASIL (2000) em sua lei 9985/2000, as UCs são divididas em 12 categorias de acordo com os seus objetivos específicos que, se diferenciam pela forma de conservação e usos permitidos.

Excetuando-se as Estações Ecológicas e Reservas Biológicas, a Lei 9985/2000 no capítulo II, artigo quatro, tem como um dos objetivos, favorecer e promover a educação e interpretação ambiental que, de certa forma, estão diretamente ligadas à recreação nesses locais.

A educação ambiental é uma das bases que garante a qualidade ambiental, saúde e bem estar da população além, do fortalecimento da economia. Promovida legalmente há muitas décadas, ela foi se moldando e ganhando espaço com o passar dos anos. Por possuir um caráter multidisciplinar, a educação ambiental passou a ser frequentemente inserida nas Diretrizes Pedagógicas ou Curriculares de acordo com a Resolução no 2/2012 pelo Conselho Nacional de Educação além, de adquirir uma lei própria como é o caso da Lei 9795/1999 regulamentada pelo Decreto no 4281.

Ainda em 1981, a Lei 6938 que instituiu a política Nacional do Meio Ambiente, já enunciava a Educação Ambiental como um dos princípios para a preservação, melhoria e qualidade ambiental. A própria Constituição Federal de 1988, em seu artigo 225, no inciso VI, do parágrafo primeiro do capítulo VI, incube o poder público de promover "a educação ambiental em todos os níveis de ensino e a conscientização pública para a preservação do meio ambiente".

A educação ambiental praticada nas UCs é considerada, segundo a Lei 9795/1999 em seu artigo 13, uma educação ambiental não formal, onde as ações e práticas educativas são voltadas para a sensibilização das pessoas, fornecendo diferentes percepções ambientais que possibilitam o resgate do elo entre homem e natureza. Com tudo o que foi descrito, objetiva-se com esse trabalho ressaltar a importância da educação ambiental através do uso público nas UCs.

\section{METODOLOGIA}

Trata-se de um estudo bibliográfico sobre a contribuição do uso público nas UCs para a educação ambiental do ser humano. Para tal, utilizaram-se as Legislações Ambientais Brasileiras e artigos publicados em Anais, entre 2011 e 2013, disponíveis eletronicamente de forma gratuita, acerca das percepções e sensibilidades adquiridas ao longo do processo de educação ambiental, tanto em indivíduos que possuíam convivência em áreas verdes, quanto naqueles que não a detinham.

\section{RESULTADOS E DISCUSSÃO}

O ritmo acelerado do dia a dia da população urbana tem causado cada vez mais o distanciamento das mesmas com a natureza como um todo. Muito comumente, a sociedade não se considera como parte da natureza e muito menos consegue enxergar a sua ligação com a mesma, o que a faz distinguir meio ambiente e meio urbano.

A educação ambiental quando apenas verbalizada gera na sociedade a percepção do respeito ao ambiente mais natural, mas não a faz se sentir integrada a ele. HOEFFEL et al. (2004), em sua pesquisa prática na Bacia Hidrográfica do Rio Atibainha, constatou que a população residente do local, considera a educação ambiental como um processo no qual as pessoas são ensinadas a cuidar e respeitar a natureza mas não necessariamente se inserir a ela.

Apesar dessas "distorcidas" percepções, a sociedade comumente busca o contato com ambientes naturais para relaxamento psicológico e diminuição do estresse. Segundo Valejo (2013), para fugir dos espaços urbanos, as pessoas buscam áreas que estimulam o contato com o silvestre, seja para a prática de um esporte, busca pelo silêncio, ar puro ou contemplação. 
O uso público nas UCs, é capaz de atender essa busca do ser humano pelo natural e, tem em sua composição a educação ambiental que, se conjuntamente praticada e vivenciada, tende a causar no indivíduo, um grau de comprometimento maior com o natural que, ao ser agregado em seu comportamento, é refletida em suas ações. Além disso, Valejo (2013), afirma que o contato de visitantes com áreas preservadas trazem não apenas benefícios à saúde, mas também, estimula o engajamento nos movimentos sociais em prol da preservação e consequente valorização desses espaços.

Para PONTES (2013), a conservação da biodiversidade nas UCs para visitação permite, além da visualização da beleza cênica, a compreensão da função ecológica no ambiente natural e da importância atrelada a espécie humana.

Por outro lado, há quem critica a visitação nas UCs devido aos impactos negativos causados pelo homem mas, é importante ressaltar que com um bom plano de manejo elaborado, esses impactos podem ser minimizados. Para VALEJO (2013), os potenciais impactos causados em uma área de vegetação silvestre estão diretamente ligados ao volume e frequência de visitação e, a natureza das atividades desenvolvidas.

Além do mais, quanto melhor a qualidade da educação ambiental recebida e, maior a vivência em meio natural, melhor será a interpretação ambiental da sociedade e consequentemente, haverá uma menor tendência de impactos negativos já que ao longo desse processo, ocorrerá uma alteração comportamental no indivíduo.

\section{CONCLUSÃO}

As UCs exercem um papel que vai muito além da proteção da fauna e flora. 0 uso público quando bem gerenciado, é uma importante ferramenta para promover a educação ambiental através de percepções ambientais bem como a resgatar o pertencimento homem-natureza de quem a visita.

A vivência em meio a áreas silvestres atrelada a educação ambiental, possibilitam despertar nos visitantes um maior grau de sensibilidade ambiental do que a educação ambiental apenas verbalizada com leituras, palestras ou ainda, punições (multas, suspensão, detenções) quando na ocorrência de um crime ambiental.

Por ser um processo de construção intrínseca, a educação ambiental requer tempo, ações integradas no dia a dia da sociedade e principalmente, de vivências práticas em meio natural com relevante preservação, como ocorre nas UCs.

\section{REFERÊNCIAS}

[1] BARBOSA, R. A; SANTOS, C. S; RITÁ, F. S. Manual básico para elaboração do resumo completo. 3. ed. Poços de Caldas: Congresso Nacional do Meio Ambiente. 2020. 10 p., ISSN on-line N² 2317-9686 - V. 12 N.12020

[2] BRASIL. Lei no 9795, de 27 de abril de 1999. Dispõe sobre a educação ambiental, institui a Política Nacional de Educação Ambiental e dá outras providências. Lei 9795. Brasília, DF, 28 abr. $1999 . \quad$ Disponível em: https://wp.ufpel.edu.br/educambiental/files/2017/05/LEI-FEDERAL-No-9795-DE-27-DE-ABRIL-DE-1999-Politica-Nacional-deEducacao-Ambiental.pdf. Acesso em: 21 jul. 2020.

[3] _. MINISTÉRIO DO MEIO AMBIENTE. Unidades de Conservação: O que são. 2012. Disponível em: https://www.mma.gov.br/informma/itemlist/category/34-unidades-de-conservacao. Acesso em: 21 jul. 2020.

[4] BRASIL. Ministério do Meio Ambiente. SNUC - Sistema Nacional de Unidades de Conservação da Natureza: Lei no 9.985, de 18 de julho de 2000; Decreto no 4.340, de 22 de agosto de 2002; Decreto no 5.746, de 5 de abril de 2006.

[5] BRASIL. Resolução no 2, de 30 de janeiro de 2012. Define Diretrizes Curriculares Nacionais para o Ensino Médio. Resolução № 2, de 30 de Janeiro 2012. Brasilia, DF, 31 jan. 2012. Seção 1, p. 20-28. Disponível em: http://portal.mec.gov.br/index. php?option=com_docman\&view=download\&alias=9864-rceb002-12\&Itemid=30192. Acesso em: 20 jul. 2020

[6] HOEFFEL, J. L.; SORRENTINO, M.; MACHADO, M. K. Concepções sobre a natureza e sustentabilidade: um estudo sobre percepção ambiental na Bacia do Rio Atibainha-Nazaré Paulista/SP. 2º Encontro da Associação Nacional de Pós-Graduação e Pesquisa em Ambiente e Sociedade. Anais... ANPPAS, $2011 . \quad$ Disponível em: http://www. anppas.org.br/encontro_anual/encontro2/GT/GT10/luis_hoffel.pdf. Acesso: 22 Jul. 2020.

[7] Pontes, J. A. L.; Mello, F. A. P. Uso público em unidades de conservação de proteção integral: considerações sobre impactos na biodiversidade. Revista Eletrônica Anais Uso Público em Unidades de Conservação. V.1. n.1, p.221-232.2013. Disponível em: https://www.researchgate.net/profile/Flavio_Augusto_Mello/publication/282669434_Uso_publico_em_unidades_de_conservacao_d e_protecao_integral_consideracoes_sobre_impactos_na_biodiversidade/links/5617beb308ae3eadf96af97b.pdf. Acesso em: 22 jul. 2020 .

[8] Vallejo, L. R. Uso público em áreas protegidas: atores, impactos, diretrizes de planejamento e gestão. Revista Eletrônica Anais Uso Público em Unidades de Conservação. V.1. n.1, p.13-26.2013. Disponível em: 
Meio Ambiente em Foco - Volume 13

https://periodicos.uff.br/uso_publico/article/view/28674/16633\#. Acesso em: 21 jul. 2020. 


\section{Capítulo 2}

\section{Análise da Participação Social voltada para a Educação Ambiental}

\section{Letícia Paschoaletto Dias}

Jane Margaret Costa de Frontin Werneck

Resumo: As questões ligadas ao meio ambiente passaram a ter maior destaque a partir de três grandes eventos: a Conferência das Nações Unidas sobre o Meio Ambiente Humano (Conferência de Estocolmo); a Conferência das Nações unidas para o Meio Ambiente e Desenvolvimento (Rio-92) e a Cúpula Mundial sobre Desenvolvimento Sustentável (Rio+10). Estas conferências marcaram a era do desenvolvimento sustentável, e desde então, a educação ambiental e a participação social nas questões ambientais ganharam grande foco para alcançarmos uma gestão pública eficaz, além de propiciar uma conexão do cidadão com o meio ambiente. Sendo assim, este trabalho teve como objetivo analisar o engajamento das pessoas às questões ambientais através de um questionário on-line, contendo 10 perguntas e disponibilizado nas redes sociais por uma semana. Dentre as 83 pessoas que participaram da pesquisa, 76 são do RJ, 3 de MG, e 1 pessoa de cada estado a seguir: ES, AL, CE e SP. Mais da metade dos participantes disseram saber pouco sobre meio ambiente, entretanto, 81,9\% acreditam poder praticar hábitos sustentáveis no seu dia-a-dia. Frequentemente, $61,1 \%$ se deparam com questões ambientais em sua vivência diária, todavia 48,2\% dizem se envolver com essas questões apenas eventualmente. Metade dos participantes apontaram não ter nenhum projeto ambiental em seu bairro, mas todos (100\%) acham a educação ambiental muito importante nos dias atuais. E 64,6\% acham a sociedade em si, pouco engajada com os assuntos relacionados ao meio ambiente. Com esse estudo, foi possível evidenciar que grande parte das pessoas assume não conhecer propriamente questões relacionadas ao meio ambiente, e se envolve pouco nas questões ambientais, porém, todos os participantes acreditam na importância da educação ambiental para criação de pensamento consciente e atitudes visando a preservação e conservação da natureza. Conclui-se que ações de educação ambiental vem sendo cada vez mais necessárias para promover conhecimento a respeito da sustentabilidade, incentivando a participação da sociedade.

Palavras-Chave: conscientização; meio ambiente; sociedade, sustentabilidade. 


\section{INTRODUÇ̃̃OO}

A população humana era quantificada em 27 milhões há 2.000 a.C, e o impacto ambiental, portanto, era mínimo se comparado ao atual, com 7,8 bilhões de pessoas no planeta Terra. A relação entre o homem e a natureza gera grandes conflitos socioambientais, e no Brasil, isso é visto de forma clara a partir da exploração e contrabando de animais e recursos naturais. (Dias, 2013)

Entre 1959 e 1964, alguns autores deram início aos debates referentes às modificações na natureza feitas pelo homem, entre eles, Charles Darwin ao publicar o livro "A Origem das Espécies"; Thomas Huxley em sua publicação de "Evidence as to man's place in nature" (Evidências sobre o Lugar do Homem na Natureza) e George Perkin Marsh em seu livro "Man and nature: physical geography as modified by human action" (O Homem e a Natureza: a Geografia Física Modificada pela Ação do Homem). (Diegues, 2001)

No Brasil, em 1920, o Pau-Brasil já era considerado extinto, e não tínhamos códigos florestais voltados para seu uso e exploração. Por conta do modo extensivo de utilização das terras com o gado, cafeicultura e silvicultura, em 1934 foi feito um decreto que, posteriormente se transformou na Lei no 4.771 , definindo o Código Florestal Brasileiro, tendo grande efeito positivo, o que levou à criação da primeira Unidade de Conservação do país. (Dias, 2013)

Em 1962, a bióloga Rachel Carson publicava seu livro intitulado "Silent Spring" (Primavera Silenciosa), um clássico que trouxe os primeiros alertas de agravamento dos impactos ambientais e uso de pesticidas, além das consequências destes para a qualidade de vida de diversos ecossistemas e da sociedade de forma geral. E em 1968, um grupo de cientistas se reuniram em Roma para discutir sobre a crise ambiental, o que definiu este marco como "Clube de Roma". (Dias, 2013. Barbieri \& Silva, 2017)

Na Conferência das Nações Unidas sobre o Meio Ambiente Humano (posteriormente chamada de Conferência de Estocolmo), realizada em Estocolmo, no ano de 1972, um evento que reuniu 113 países a fim de tentar fazer com que a relação homem-natureza fosse mais harmoniosa, foi gerado um documento chamado "Declaração Sobre o Ambiente Humano". E neste difícil momento de discussão voltado para a crise ambiental, o Brasil foca no modelo de desenvolvimento econômico, restrito que não procura condições favoráveis e sustentáveis para a população. (Dias, 2016; Barbieri \& Silva, 2011; Queiroz \& Camacho, 2016)

Apenas em 1977 ocorreu o evento importante para a Educação Ambiental (EA), que foi a Conferência Intergovernamental de Tbilisi sobre Educação Ambiental, na Georgia, e tinha como finalidade dar continuidade nas discussões promovidas em Estocolmo, determinando as características da EA e as estratégias que precisariam ser tomadas para incluir essa questão na educação escolar. (Queiroz \& Camacho, 2016)

A Lei 6.938 foi sancionada em 1981, que determina a Política Nacional do Meio Ambiente, além de criar o Conselho Nacional do Meio Ambiente (CONAMA), e apenas sete anos mais tarde foi instituída a Lei 7.735, criando o Instituto Brasileiro do Meio Ambiente (IBAMA). (Dias, 2013)

Já em 1992, ocorreu a Conferência da ONU sobre Meio Ambiente e Desenvolvimento (RIO 92), e nela foi evidenciado como o modelo de desenvolvimento vigente era insustentável, nomeando a Agenda 21 como plano de ação. Nesse contexto, a EA foi de fato reconhecida como estratégia para o desenvolvimento, e a partir disso, diferentes documentos foram propostos, como "Declaração sobre Desenvolvimento e Meio Ambiente", "Carta da Terra" e o "Tratado de Educação Ambiental para Sociedades Sustentáveis e Responsabilidade Global". No Brasil, a EA ganha ênfase em termos legais apenas em 1994, com a formulação do Programa Nacional de Educação Ambiental (PRONEA). (Dias, 2017; Hoshi, 2012)

No ano de 1999 ocorreu o evento da I Conferência Nacional de Educação Ambiental, sendo um marco na EA do Brasil, já que contou com quase 3 mil participantes, além de mobilizar estudantes, professores e autoridades do país. Após isso, o MEC introduziu o meio ambiente como temática transversal nos novos Parâmetros Curriculares Nacionais. E nesse mesmo ano, em Kyoto no Japão, ocorria um evento que gerou na assinatura do Protocolo de Kyoto, onde os países que possuíam as maiores porcentagens referentes a poluição e industrialização se comprometerem a reduzir as emissões de gases estufa. (Barbieri \& Silva, 2011)

A Cúpula Mundial sobre Desenvolvimento Sustentável, conhecida também como Rio+10, aconteceu em 2002 e tinha como objetivo discutir e renovar os compromissos feitos pelos países na Rio-92. (Dias, 2017) 
A Conferência de Estocolmo, a Rio-92 e a Rio+10 foram eventos importantes para a temática ambiental pois marcaram a era do desenvolvimento sustentável e permitiram que a educação ambiental fosse discutida e aprofundada, tornando-a uma meta central na busca da sustentabilidade e na proteção e cuidado com a natureza. Nesse sentido, a EA é necessária para formação de crianças, adultos e jovens promotores de conhecimento e críticos com relação às questões ambientais.

Pelo breve histórico aqui apresentado, e tendo em vista a relevância do mesmo no contexto atual, a introdução dos temas ambientais de forma mais efetiva na sociedade pode ser intensificada e melhor implementada através da EA. Desta forma, o trabalho em questão procurou analisar o engajamento das pessoas frente às questões ambientais, com a finalidade de compreender se essa temática chega na população e como ela chega, enfatizando a EA para promoção de conhecimento.

\section{METODOLOGIA}

\subsection{APLICAÇÃO DE QUESTIONÁRIO}

Foi criado um questionário on-line através do Google Forms, contendo dez perguntas, e o mesmo foi disponibilizado em três redes sociais, sendo elas: Instagram, Facebook e Whatsapp. As perguntas do questionário estavam voltadas para a temática da sustentabilidade e para o engajamento da sociedade referente a esse assunto.

\subsection{ANÁLISE DOS QUESTIONÁRIOS}

Uma planilha foi construída com as respostas das 83 pessoas participantes, o que possibilitou quantificar tais respostas e elaborar gráficos para melhor visualização do que se foi obtido em cada uma delas, além de expor o percentual de cada alternativa.

Tabela 1. Quantidade de participantes por Estado.

\begin{tabular}{|l|c|}
\hline \multicolumn{1}{|c|}{ ESTADOS } & N \\
\hline Rio de Janeiro & 76 \\
\hline Minas Gerais & 3 \\
\hline São Paulo & 1 \\
\hline Espírito Santo & 1 \\
\hline Ceará & 1 \\
\hline Alagoas & 1 \\
\hline \multicolumn{1}{|c|}{ Total } & 83 \\
\hline
\end{tabular}

\section{RESULTADOS}

Os resultados a seguir apresentam algumas das perguntas abordadas no questionário.

Observamos grande participação de professores de nível básico/médio, pessoas outras profissões não determinadas no questionário, e alunos de graduação, como mostra o gráfico abaixo. (Figura 1) 
Figura 1. Gráfico referente a pergunta: Você se enquadra em alguma dessas opções? * Marque mais de uma opção se for o caso.

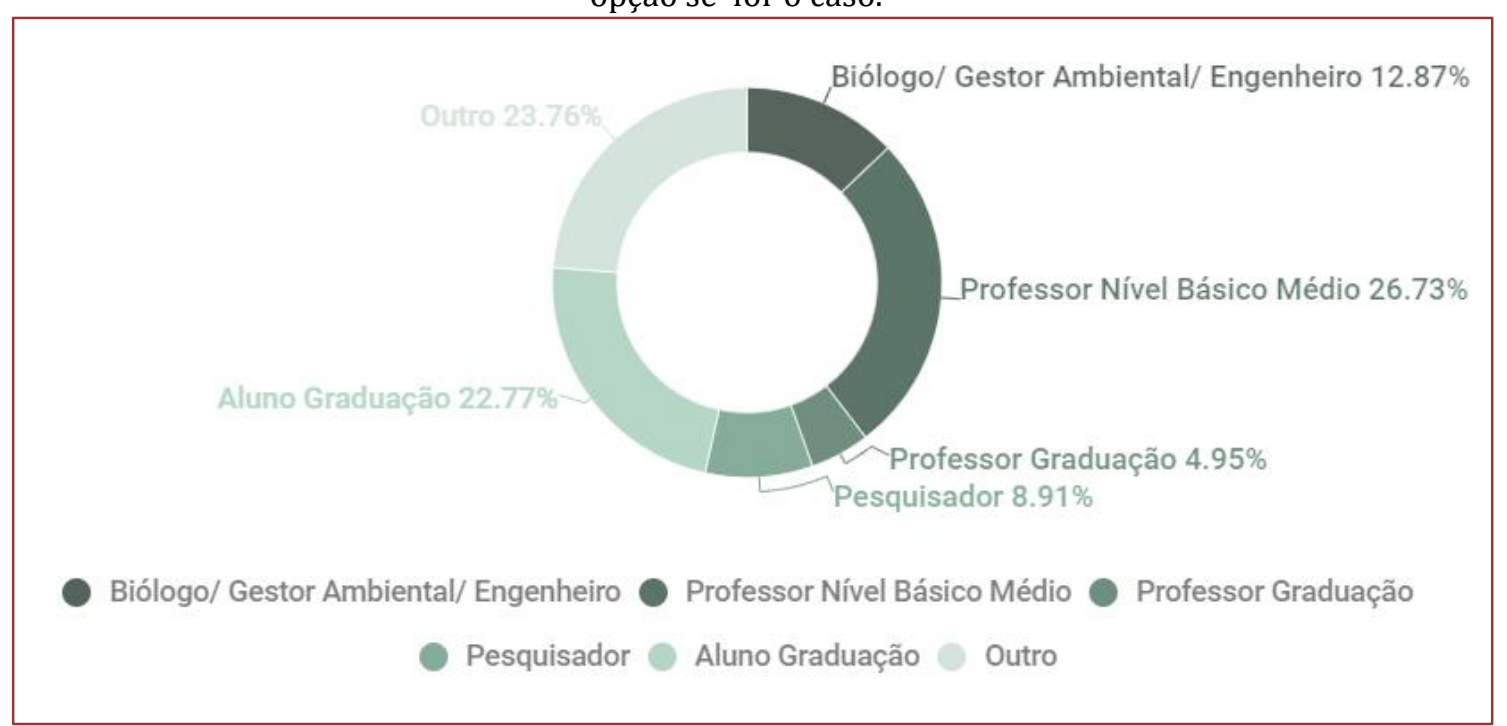

Ao perguntarmos aos participantes se eles sabiam sobre questões voltadas para ambiente, relação homem $\mathrm{x}$ natureza, reciclagem e cuidados com solo, água e animais, mais da metade dos participantes disse que Sim, enquanto $41 \%$ deles mostrou Não saber, e uma pequena parcela demonstrou saber Um pouco, evidenciando que poderia saber mais. (Figura 2)

Figura 2. Gráfico referente a pergunta: Você acredita saber bastante coisas sobre o meio ambiente e coisas correlatas como: reciclagem, relação homem x natureza, importância da natureza, cuidados com solo, água e animais de forma geral?

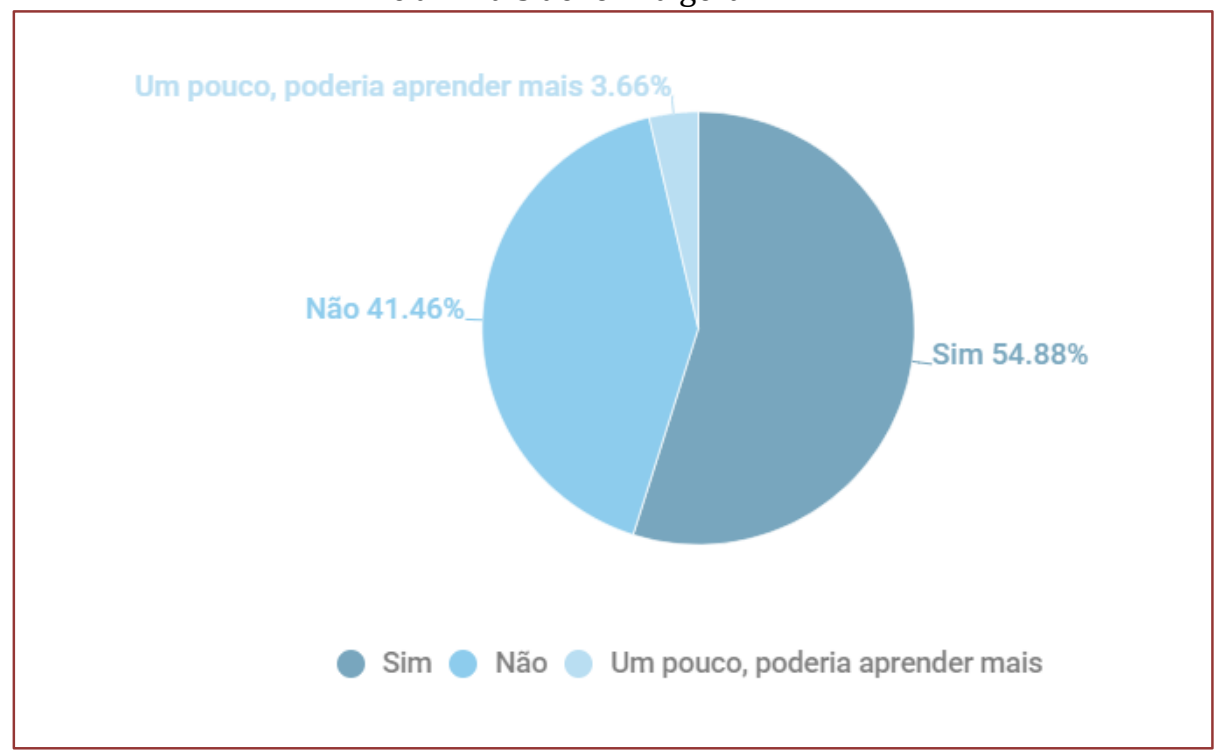

Sobre o tema sustentabilidade, $97 \%$ disseram saber o que é, enquanto apenas duas pessoas escolheram a alternativa Não, afirmando não entender o que é sustentabilidade.

Quando perguntamos aos participantes sobre a possibilidade de conseguirem praticar hábitos sustentáveis em seu dia-a-dia, grande parte das respostas evidenciou que Sim, é possível ter essa prática, já 16,87\% mostrou que Não, e 1,20\% Talvez. (Figura 3) 
Figura 3. Gráfico referente a pergunta: Você acredita poder praticar hábitos sustentáveis no seu dia-adia?

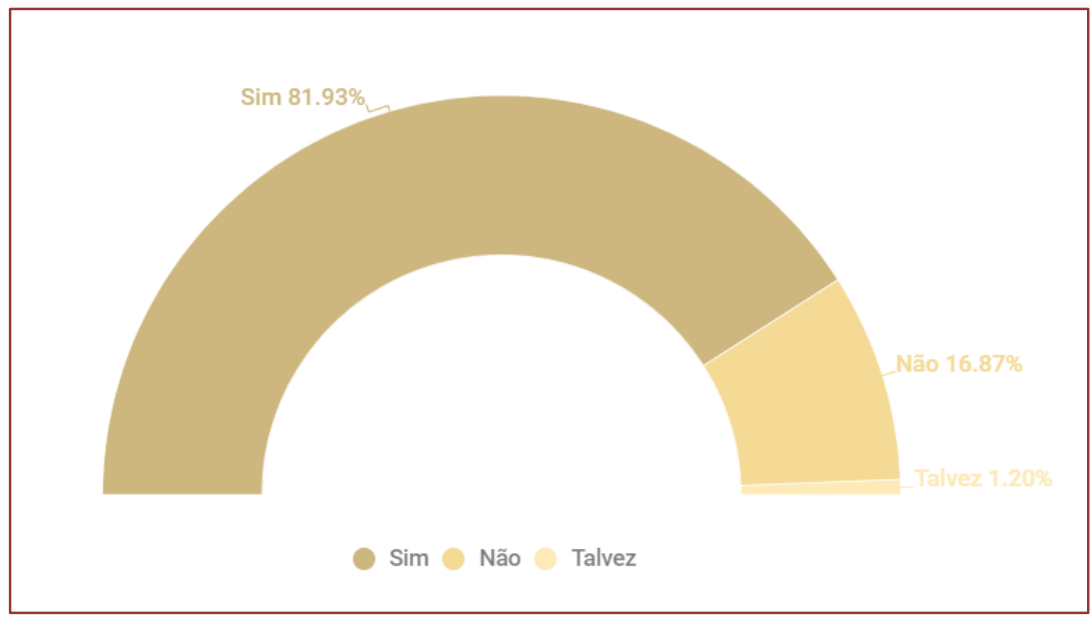

No gráfico abaixo é possível observar as respostas referentes às duas frentes analisadas: 1) se diariamente as pessoas se deparam com questões ambientais, ou seja, se as pessoas ouvem, leem e veem informações sobre a questão ambiental; e 2) se diariamente as pessoas se envolvem com questões ambientais, ou seja, se elas debatem sobre, postam na internet e/ou estimulam tais questões em seu dia-a-dia.

O gráfico evidenciou que referente a resposta Frequentemente, a proposta 1 apresentou 51\% de marcações, enquanto a proposta 2, apenas 27\%, mostrando que, nem todas as pessoas que frequentemente se deparam com tais questões, de fato se envolvem. Sobre a alternativa Às vezes, é possível visualizar 25\% na proposta 1 e $40 \%$ na proposta 2, onde fica claro que as pessoas preferem se envolver as vezes nessa temática. Os participantes marcaram a opção Raramente em 7\% na proposta 1 e $12 \%$ na proposta 2, e $4 \%$ dos participantes disseram Nunca se envolver com as questões ambientais.

Figura 4. Gráfico referente a pergunta: 1- Em sua vivência diária, você se depara com questões ambientais? e 2- Em sua vivência diária, você se envolve com questões ambientais?

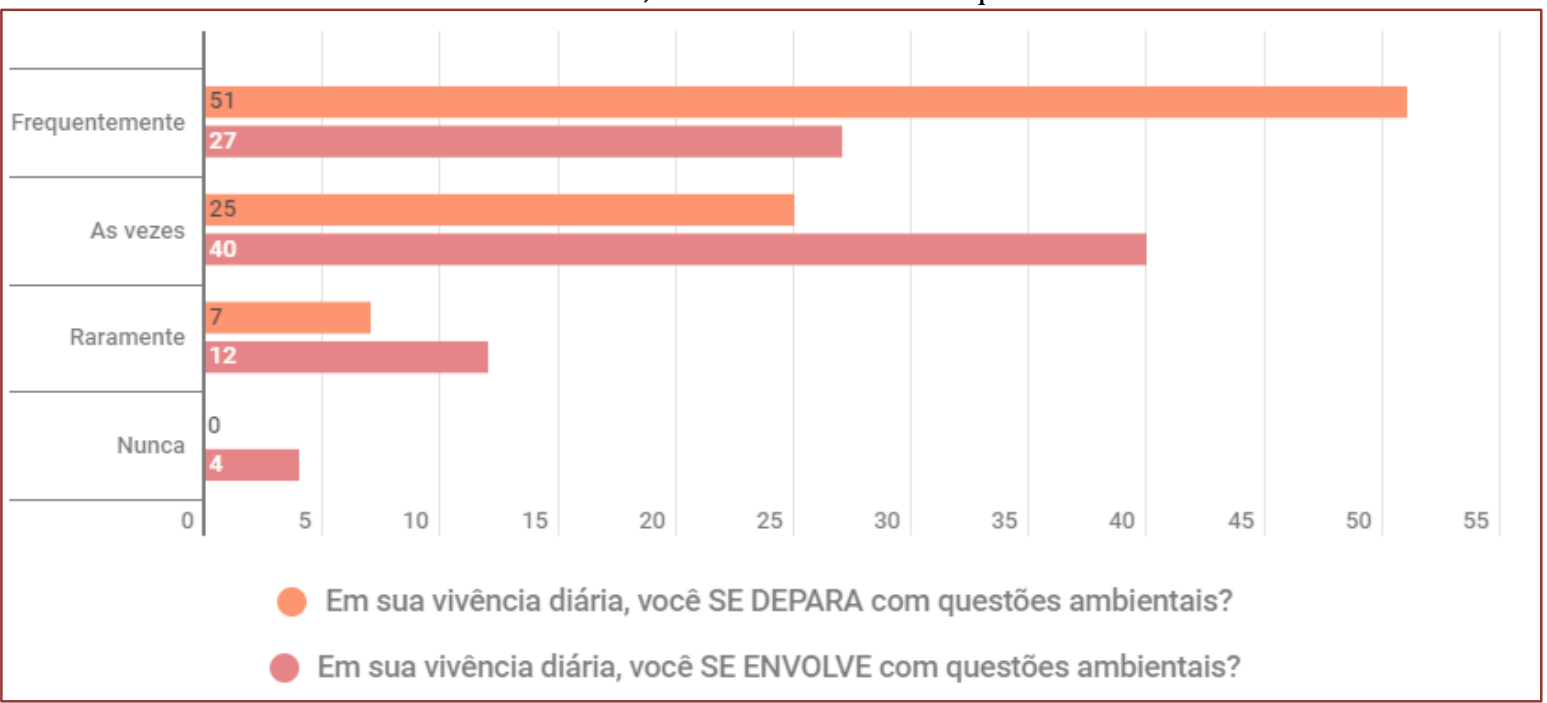

Quando perguntamos aos participantes se existem projetos nos bairros onde eles moram que sejam voltados para sustentabilidade, reciclagem, conservação ou afins, metade deles disse que Não, 28,92\% disse que Sim, e 20,48\% dos entrevistados disse não saber. (Figura 5) 
Figura 5. Gráfico referente a pergunta: No seu bairro há algum projeto voltado para sustentabilidade, conservação, reciclagem ou afins?

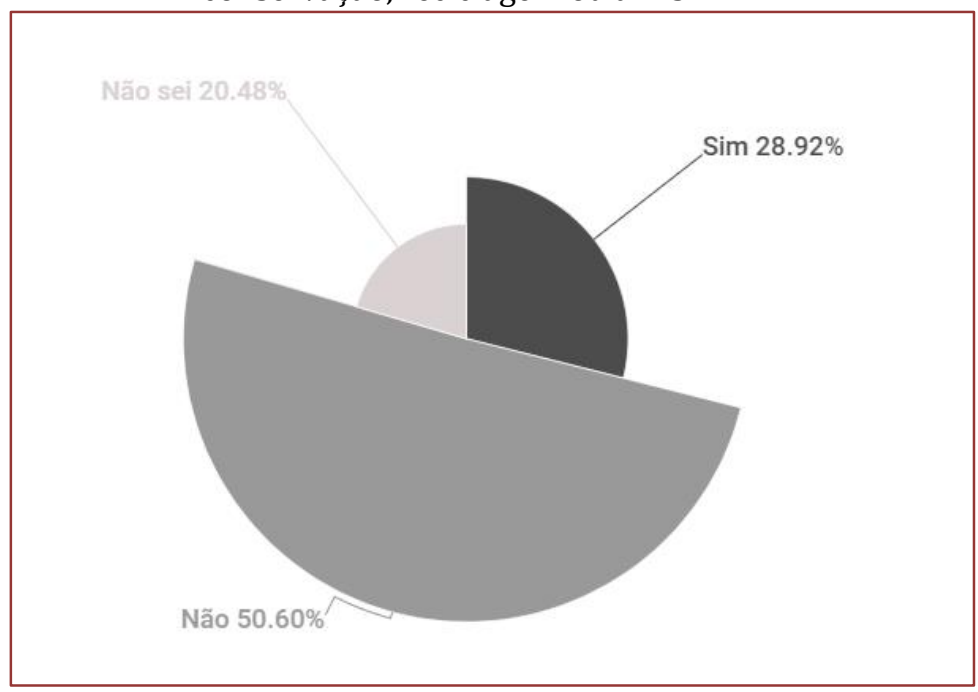

Quando perguntamos aos participantes se eles viam a sociedade engajada com as questões ambientais, apenas 1 pessoa (1,2\%) respondeu Muito, 17 (13,41\%) responderam Razoavelmente, 53 pessoas $(64,63 \%)$ marcou a alternativa Pouco e 11 afirmou que a sociedade Não é engajada.

Figura 6. Gráfico refere a pergunta: Você vê a sociedade engajada com as questões ambientais?

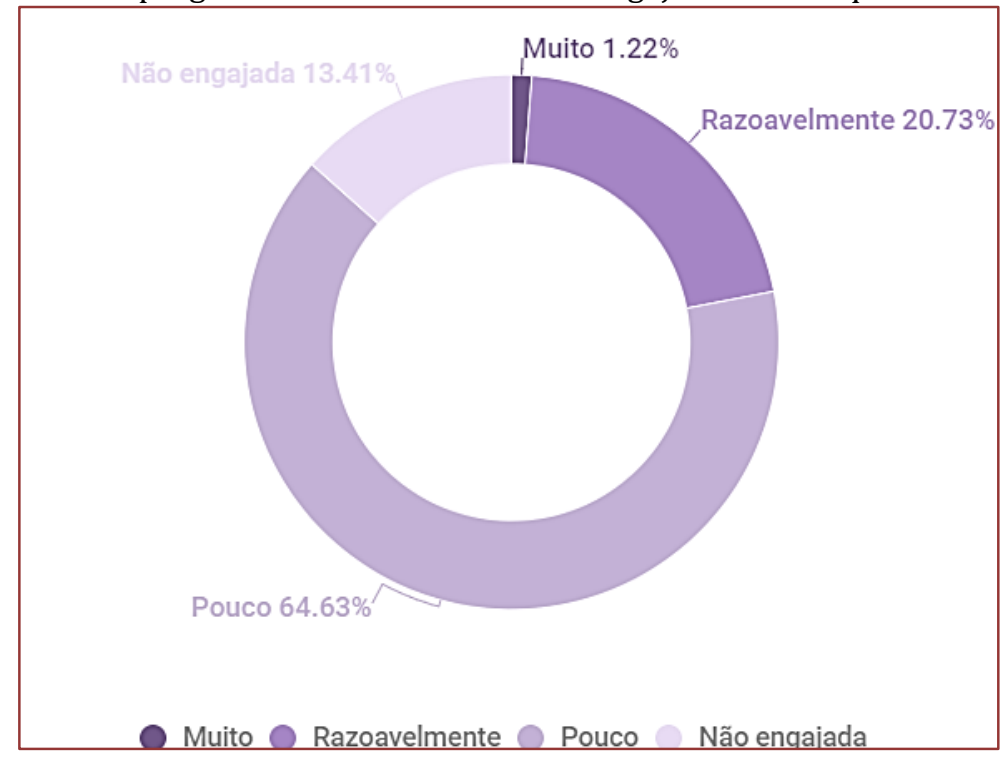

E, por fim, ao perguntarmos quão importante a educação ambiental é nos dias atuais, todos os participantes do estudo responderam que consideram a EA importante. 


\section{DISCUSSÃO}

Atualmente, o conhecimento da população sobre a temática ambiental não apresenta os melhores resultados, entretanto, evidencia uma crescente tanto na aquisição de conhecimento como nas práticas diárias voltadas para natureza e para minimizar os impactos causados pelo ser humano.

Parte desse avanço se deu pelas tecnologias digitais, que permitem uma aproximação das pessoas a determinados assuntos, já que através dos noticiários, posts em redes sociais, sites e até mesmo desenhos infantis, conseguimos obter informações e conhecimentos mais gerais. Com intenção pedagógica ou não, os assuntos referentes ao meio ambiente têm conseguido atingir o expectador, como também foi explorado por Marchiorato (2018). Isso também pôde ser evidenciado nos resultados que obtivemos, onde grande parte dos participantes mostrou conhecer temas ligados ao meio ambiente, além de compreenderem o que é sustentabilidade e mostrarem-se dispostos a praticar hábitos mais sustentáveis, que pode ter tido influência da mídia.

Esse estudo retratou bem como a sociedade tem dificuldade de se envolver em questões ambientais, o que pode ter sua motivação ligada à política, ideologias e até mesmo culturas. E a percepção de grande parte dos participantes sobre o pouco engajamento da sociedade nos assuntos ligados ao meio ambiente pode ter relação com o distanciamento ainda existente entre a sociedade e práticas educativas ambientais, além da falta de uma gestão pública e ambiental eficaz e o modelo de desenvolvimento capitalista atual, onde a natureza é vista apenas como recurso para obtenção de lucro. Oliveira (2005) e Bezerra et al. (2013) desenvolveram, em seus estudos, paradoxos do desenvolvimento econômico e político em detrimento das condições ambientais e mostraram como é necessária a mudança no sistema de produção, além de diálogos entre todos.

Por todos os participantes concordarem com a importância da educação ambiental nos dias atuais, acredita-se que, mesmo não tendo conhecimentos aprofundados por cada temática explicitada nem mesmo terem vivenciado tais questões de forma prática, as pessoas entendem a importância da educação ambiental nos dias atuais. Bortolon \& Mendes (2014) realizaram um estudo que procurou entender se a EA tem importância para o alcance de discussões sobre um desenvolvimento sustentável e comprovaram a eficácia dessa disciplina em escolas, da mesma forma que Silva \& Santos (2017) confirmaram a mesma questão, agora voltada para graduandos.

Conclui-se que ações de educação ambiental vem sendo cada vez mais necessárias para promover conhecimento a respeito da sustentabilidade, incentivando e potencializando a participação da sociedade. 0 respectivo trabalho também mostra como há muito poucos estudos sobre o engajamento ambiental, sendo assim, ele colabora para um maior conhecimento sobre o assunto, além de trazer questões relevantes.

Todas as esferas, desde o empresariado até crianças, devem estar unidas para entender as necessidades atuais que prejudicam o planeta, propondo mudanças às grandes corporações, produtores rurais e trabalhadores no geral, para que juntos, possamos construir uma ponte que esteja focada em um desenvolvimento mais sustentável. (Roos \& Becker, 2012)

\section{REFERÊNCIAS}

[1] Barbieri JC, Da Silva D. Desenvolvimento sustentável e educação ambiental: uma trajetória comum com muitos desafios. RAM Rev Adm Mackenzie 2011; 3(12).

[2] Bezerra CAB, Costa TC, Da Silva VM, Do Nascimento RGF, Araújo MPM. Desenvolvimento Sustentável na Sociedade Capitalista: os rumos da energia renovável no RN. VI Internacional de Políticas Públicas 2013.

[3] Bortolon B, Mendes MSS. A importância da Educação Ambiental para o Alcance da Sustentabilidade. Rev Eletrônica de Iniciação Científica 2014; (5):118-136.

[4] Dias SE. Os (des) encontros internacionais sobre meio ambiente: Da conferência de Estocolmo à Rio+20 expectativas e Contradições. Caderno Prudentino de Geografia 2017; 39(1):06-33.

[5] Donaldo BS, Novicki VA. A Participação Social na Questão Ambiental: limites e possibilidades nos Conselhos de Meio Ambiente no Brasil. Fundação Cesgranrio 2011; (3)7.

[6] Marchiorato HB. Educação Ambiental: A tecnologia a favor da natureza. Kínesis 2018; (23):85-99.

[7] Oliveira LD. A Ideologia do Desenvolvimento Sustentável: notas para reflexão. Ver Tamoios 2005; (2):41.

[8] Queiroz FLL, Camacho RS. Considerações acerca do debate da educação ambiental presente historicamente nas conferências ambientais internacionais. Fórum Ambiental da Alta Paulista 2016; 1(12). 
[9] Roos A, Becker LSP. Educação Ambiental e Sustentabilidade. Rev Eletrônica em Gestão, Educação e Tecnologia Ambiental 2012; (5):857-866.

[10] Santos FR, Silva AM. A importância da educação ambiental para graduandos da Universidade Estadual de Goiás: Campus Morrinhos. Interações 2017; 18(2):71-85. 


\section{Capítulo 3}

\section{A mobilização social em questões ambientais no Paraná: O caso da APA da Escarpa Devoniana e o Projeto de Lei 527/2016}

\section{Lia Maris Orth Ritter Antiqueira}

Katya Cristina de Lima Picanço

\section{Danislei Bertoni}

Resumo: A Área de Proteção Ambiental da Escarpa Devoniana é a maior Unidade de Conservação do estado do Paraná, abrigando a biogeodiversidade da região dos Campos Gerais, sob a formação geológica de mesmo nome. Por meio de um Projeto de Lei apresentado à Assembleia Legislativa do Estado do Paraná, em 2016, foi proposta a redução de $70 \%$ da área, a fim de atender interesses do agronegócio. Objetiva-se neste capítulo discutir o envolvimento da sociedade nesta questão que trouxe implicações diretamente sobre os direitos de milhares de cidadãos residentes nos 13 municípios perpassados pela APA. Este envolvimento contou com a sociedade civil, instituições, grupos de pesquisa, coletivos, universidades e organizações não governamentais. Dentre as ações mais expressivas da coletividade, foram enviados mais de 167 mil e-mails aos parlamentares, além de mais de cinco mil assinaturas em um abaixo assinado manifestando indignação com relação à inconstitucionalidade da proposta. 0 movimento contou, também, com a participação voluntária de personalidades da mídia nacional, que aderiram à campanha do curta metragem "Os Últimos Campos Gerais", promovida pelo Observatório de Justiça e Conservação, e de um clipe musical intitulado "Pare, Preste Atenção". Em outubro de 2018, o projeto de lei foi retirado de tramitação pelos próprios proponentes, entendendo que o interesse de poucos não pode se sobressair ao de muitos, e que a sociedade deve se posicionar ativamente nas discussões e decisões relacionadas com as questões socioambientais, a conservação do patrimônio natural e a sustentabilidade.

Palavras Chave: Campos Gerais. Conservação da natureza. Sustentabilidade. 


\section{INTRODUÇÃO ${ }^{1}$}

Os eventos decorrentes das transformações produtivas, a partir da Terceira Revolução Industrial e a Globalização, intensificaram os processos de manipulação tecnológica e a exploração dos recursos naturais. Os derramamentos de petróleo, o envenenamento de milhares de pessoas por Mercúrio no Japão (desastre de Minamata), além de tragédias previstas com antecedência (como os efeitos deletérios dos pesticidas ao ambiente, denunciados pela bióloga Raquel Carson, em seu livro Primavera Silenciosa), entre outros desastres socioambientais, criam um panorama insustentável.

A consequência dos processos antrópicos na natureza já vem sendo relatada de maneira minuciosa em pesquisas científicas desde meados do século XX. Porém, inicialmente, os estudos eram realizados de forma isolada, considerando aspectos de fauna e flora, ou mesmo de forma restrita a uma determinada espécie ou um ecossistema de interesse. Embora importantes, esses resultados colocaram a crise ambiental sob uma perspectiva fragmentada: ao se analisar uma faceta do problema por vez, não era possível dimensionar de maneira abrangente a catástrofe iminente.

Visando preencher estas lacunas, a Biologia da Conservação surgiu no final da década de 1970, como uma tentativa interdisciplinar de conciliar a atuação de biólogos e ecólogos de diferentes áreas em prol de um objetivo comum: a conservação de espécies e ecossistemas, com base no entendimento das consequências da ação antrópica sobre os mesmos. Sua configuração como ciência foi motivada pela grave crise ambiental iniciada com a revolução industrial que cresceu exponencialmente, levando muitas espécies à extinção.

Segundo Primack e Rodrigues (2001), a Biologia da Conservação é guiada por pressupostos básicos que garantem à todas as espécies o direito de existir, pois são frutos da história evolutiva à qual se adaptaram. Além disso, são interdependentes, pois interagem de modo complexo no mundo natural e a perda de uma espécie influencia as demais.

Os seres humanos se encaixam nestas mesmas limitações e, portanto, devem zelar pela coexistência, para não prejudicar sua própria existência e nem a de outras formas de vida. Desta forma, a sociedade tem a responsabilidade de proteger o Planeta, usando os recursos de forma que não os esgotem e garantam seu fornecimento para as próximas gerações. Além disso, a natureza tem um valor estético e espiritual que transcende seu valor econômico e isso deve ser mantido (PRIMACK; RODRIGUES, 2001).

Pautadas nestes pressupostos, as iniciativas relacionadas à conservação ganharam força mundialmente, sendo que a emergência do ambientalismo contemporâneo se institui na medida em que sobressaem uma série de movimentos sociais de massa. 0 movimento ambientalista não começou em um lugar específico para depois se expandir por lugares, tempos e motivos diferentes, mas sim por meio de questões locais, com repercussão de maiores dimensões, gerando um movimento mais intenso e global.

Este movimento permitiu a mobilização e organização social e política, com olhares atenciosos para os problemas socioambientais, para a conservação do ambiente explorado, e para a preservação da natureza. Esta percepção foi crescendo e se popularizando mundialmente, a ponto de criar grandes ações de ativismo ecológico por parte de simpatizantes do tema. Surgem embasadas em informações científicas que as sustentam e tomam formato político e de resistência, quando confrontam os interesses dos grupos favorecidos economicamente com a degradação ambiental.

No entanto, no Brasil, as ações ambientalistas sempre conviveram com contradições: ao mesmo tempo em que se criavam parques nacionais, Brasília foi arquitetada no meio do Cerrado. Após a institucionalização do Parque Nacional do Iguaçu, foi construída na área uma das maiores usinas hidrelétricas do mundo. Estes exemplos ilustram claramente a falta de um princípio norteador das ações no país.

Porém, um marco histórico para o contexto ambiental foi a Constituição Federal de 1988, mais precisamente no Art. 225, ao estabelecer que todos têm direito ao meio ambiente ecologicamente equilibrado, impondo-se ao poder público e à coletividade o dever de defendê-lo e preservá-lo para as presentes e futuras gerações. Posteriormente, a instituição do Sistema Nacional de Unidades de Conservação (SNUC), no ano 2000, legitimou os espaços naturais protegidos sob a forma de parques, florestas e outras categorias de uso sustentável ou de proteção integral.

\footnotetext{
1 Versão reduzida deste capítulo foi apresentada no Congresso Nacional de Meio Ambiente (2020). A convite da editora os autores publicam agora a versão estendida.
} 
Em 2007 foi criado o Instituto Chico Mendes de Conservação da Biodiversidade (ICMBio), uma autarquia em regime especial vinculada ao Ministério do Meio Ambiente (MMA) e integrante do Sistema Nacional do Meio Ambiente (SISNAMA) com a função de executar as ações do Sistema Nacional de Unidades de Conservação, podendo propor, implantar, gerir, proteger, fiscalizar e monitorar as UCs instituídas pela União e garantir a integridade da biodiversidade do país.

Assim, a compreensão sobre a conservação da natureza passa a fazer parte da institucionalidade oficial no país, mas também de movimentos e mobilizações, que se desenvolvem localmente, com as contradições, mas, também com os avanços observados.

Há que se incluir nesse contexto, o imaginário social, cotidianamente composto por inúmeras situações que vão tecendo redes complexas. 0 cenário cinematográfico com os filmes catastróficos, os movimentos ambientalistas em todas suas vertentes, as polêmicas que envolvem as reuniões dos países mais desenvolvidos e suas buscas de protocolos e acordos, a educação ambiental nas escolas, os planos municipais de gestão dos resíduos, a história local e uma lista infinita de temáticas relativas a essa complexidade. Interesses divergentes, que impulsionam projetos de toda ordem, mas que tem na conservação ambiental a sua centralidade.

\section{IMPORTÂNCIA DA ÁREA DE PROTEÇÃO AMBIENTAL DA ESCARPA DEVONIANA E O PL DA DESTRUIÇÃO}

A Área de Proteção Ambiental (APA) da Escarpa Devoniana foi criada em 1992 com o objetivo de assegurar a proteção do limite natural entre o Primeiro e o Segundo Planaltos Paranaenses, inclusive a faixa de Campos Gerais, que se constitui em ecossistema peculiar que alterna capões da floresta de araucária, matas de galerias e afloramentos rochosos, além de locais de beleza cênica como os canyons e de vestígios arqueológicos e pré-históricos (PARANÁ, 1992).

É a maior Unidade de Conservação do estado, com 392 mil hectares de uso sustentável, englobando parte dos municípios da Lapa, Balsa Nova, Porto Amazonas, Palmeira, Campo Largo, Ponta Grossa, Carambeí, Castro, Tibagi, Piraí do Sul, Arapoti, Jaguariaíva e Sengés (Figura 1). Dentro dos limites da APA encontramse outras dez Unidades de Conservação de uso mais restrito, incluindo quatro parques estaduais e um nacional. Porém, o uso do solo no entorno e as irregularidades cometidas dentro da própria APA a colocam em situação de constante pressão antrópica com risco de extinção de espécies e ecossistemas.

Com intuito de assegurar a conservação deste patrimônio natural de peculiaridade indescritível, além dos estudos realizados e da busca constante de sensibilização para as questões ambientais, pesquisadores da Universidade Estadual de Ponta Grossa propuseram, no ano de 2012, à Secretaria de Estado e Cultura do Paraná, o tombamento da referida área, com objetivo de preservar os remanescentes naturais da região dos Campos Gerais (PARANÁ, 2012).

Em contraponto a estas questões e atendendo ao interesse do setor de agronegócio, foi proposto o Projeto de Lei (PL) no 527, em novembro de 2016, que previa a redução da área da APA em aproximadamente 70\% de sua extensão, configurando-a em 126 mil hectares (PARANÁ, 2016). O "PL da Destruição" tramitou por dois anos até ser discutida pela Comissão de Ecologia, Meio Ambiente e Proteção aos Animais, e posteriormente ser encaminhada para votação em Plenário. 
Figura 1: Delimitação da APA da Escarpa Devoniana no Estado do Paraná.

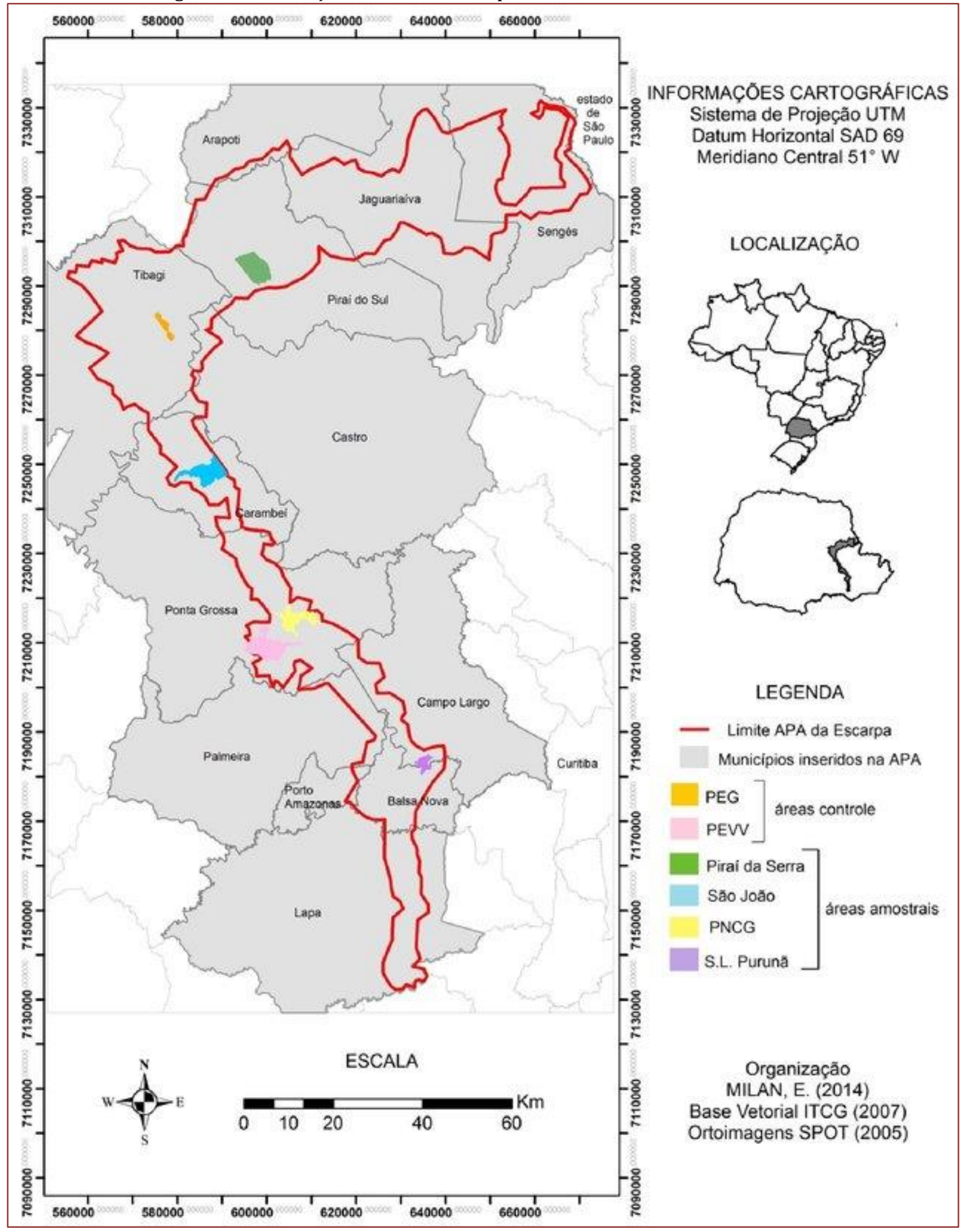

Fonte: MILAN (2014)

O projeto embasava-se na justificativa que a criação da APA da Escarpa Devoniana baseou-se em tecnologia pouco avançada na época, e com a disponibilidade de recursos atuais foi possível reexaminar os limites da UC e propor nova delimitação. Além de reduzir a área preservada, impunha ao entorno da nova configuração uma condição de extrema pressão antrópica, ao permitir que se tornassem áreas de cultivo regular de espécies exóticas e outras formas de exploração comercial. 
Como fundamentação técnica, o PL apresentava um único estudo realizado pela Fundação ABC - Pesquisa e Desenvolvimento Agropecuário, Mapeamento, Classificação e Uso do Solo, justificando a "necessidade, conveniência, e oportunidade da presente proposição" (PARANÁ, 2016). Não incluía dados de pesquisa de diversos grupos de profissionais que estudam o patrimônio natural da referida área há mais de 30 anos, nem mesmo o parecer de especialistas da área de Conservação de Recursos Naturais, muito menos manifestação do Conselho Gestor da Unidade de Conservação ou sequer do Instituto Ambiental do Paraná (IAP), autarquia na ocasião responsável por organizar e manter o Sistema Estadual de Unidades de Conservação.

0 referido PL apontou inconstitucionalidade sobre a redução dos limites da APA, "sob pena de ferir gravemente o princípio da vedação do retrocesso em matéria ambiental" (FEDER; MATTOS, 2019, p. 15). No âmbito do Direito Ambiental, a proteção do meio ambiente deve ter prioridade em relação à exploração econômica, mais ainda se esta tende a agredir e danificar a natureza (FEDER; MATTOS, 2019).

Parte-se agora, para análise do envolvimento social de estudantes, profissionais, pesquisadores, enfim, de cidadãos engajados no movimento ambiental contra o PL 527/2016 que propôs a redução da referida APA. Isto para entender como se deu a intensa mobilização, tomando conta da Sociedade Civil que se posicionou frente a uma ação concreta, que propunha a diminuição de grande parte da área protegida, contribuindo para que o projeto fosse retirado de tramitação pelos seus proponentes, com apoio unânime dos demais parlamentares.

A interpretação dos acontecimentos desde a instituição do processo em novembro de 2016 até outubro de 2018, com o ápice da mobilização na região dos Campos Gerais no ano de 2017, permitiram observar os laços com a história, a cultura e a biodiversidade. Estes laços foram elementos-chave na mobilização e propiciaram aos diversos atores sociais se posicionarem em defesa da APA.

\section{A MOBILIZAÇÃO: DOS PRIMEIROS PASSOS ATÉ O DESFECHO VITORIOSO}

Desde que começou a tramitar na Assembleia Legislativa do Paraná, o PL 527/2016 causou verdadeiro incômodo em diversos setores da sociedade. Pesquisadores, professores, ambientalistas, moradores dos 12 municípios perpassados pela APA, simpatizantes de movimentos de todos os tipos, inclusive religiosos, se uniram frente a um objetivo comum: questionar e argumentar contra a tramitação e aprovação da referida proposta, que do ponto de vista geral atendia a um pequeno grupo de proprietários de áreas na APA, atualmente limitados em suas práticas de agronegócio pelo Plano de Manejo da Unidade de Conservação. O PL apresentou fundamentos questionáveis, uma vez que diminuir a área beneficiaria diretamente a atividade de monocultura, acarretando degradação ao meio ambiente com fins voltados basicamente ao lucro (FEDER; MATTOS, 2019).

A primeira intervenção popular realizada foi a criação de um abaixo-assinado on-line, que em pouco tempo somou mais de 5 mil assinaturas de cidadãos indignados e com posicionamento contrário à proposição e aprovação do PL. Em seguida, surgiram manifestações de grupos de pesquisa, instituições e da própria Ordem dos Advogados do Brasil (OAB), que considerou a proposta inconstitucional, por ferir o artigo 225 da Constituição Federal, que trata do direito dos cidadãos a viver em um ambiente sadio e equilibrado (BRASIL, 1988).

No dia 10 de março de 2017, foi realizada uma audiência pública no Cine Teatro Ópera, em Ponta Grossa/PR, para debater o PL 527/2016. As ruas próximas foram tomadas por manifestantes contra a proposta e o local do evento foi isolado devido à superlotação, com necessidade de policiamento. A audiência ocorreu de forma tumultuada, abafada pelo coro externo de manifestantes pedindo pela sua transferência para um local maior, a fim de que pudessem participar. Dentro do teatro lotado, mais de dez profissionais pesquisadores e estudiosos da APA da Escarpa Devoniana, deputados que propuseram o projeto, representantes da Fundação ABC, do IAP, da SANEPAR, do ICMBio, professores de universidades, advogados, dentre outros, apresentando os prós e contras. Por mais de quatro horas, o assunto foi debatido de forma tensa, com manifestações inclusive de intolerância à participação popular no ato (ANTIQUEIRA, 2017a).

A maioria massiva criticou a proposta sob diversos pontos de vista, apontando erros técnicos na proposição dos novos limites e consequências envolvendo aspectos ecológicos, geológicos, biológicos, culturais e econômicos. 0 termo mais comum aplicado para definir a questão foi "retrocesso ambiental". 
A audiência pública repercutiu na mídia televisiva e impressa por vários dias, fomentando mais ainda a discussão sobre o tema e a necessidade de não se tomar nenhuma decisão precipitada sobre um tema de interesse de milhares de pessoas. 0 assunto que já era instigante, se tornou pauta nas salas de aula (ANTIQUEIRA, 2017b), em grupos ambientalistas (DIARIO DOS CAMPOS, 2017) e gerou novos posicionamentos contra, inclusive do Conselho Municipal do Meio Ambiente de Ponta Grossa (PARANÁ, 2017)

A primeira resposta da mobilização veio por meio de um dos deputados proponentes do projeto, que retirou seu nome dizendo que a pressão popular o fez pensar, segundo sua comunicação pessoal a diversos órgãos de imprensa. A audiência fez eco na sociedade. Esse fato demonstra claramente a importância da educação científico-tecnológica na formação cidadã e crítica da sociedade, para participação pública em decisões políticas.

A mobilização tomou rumos nacionais, ganhando mais espaço nas mídias sociais com o lançamento do clipe musical "Pare, Preste Atenção" (Figura 2), iniciativa do Observatório de Justiça e Conservação (OJC), junto com um curta-metragem intitulado "Os Últimos Campos Gerais", abordando o tema de forma transparente e crítica. Em poucas semanas, estes materiais receberam mais de um milhão e meio de visualizações somente no Facebook, além da divulgação paralela em outras redes sociais, grupos de WhatsApp, listas de e-mail e até mesmo exibições públicas em eventos relacionados ao tema ${ }^{2}$. Dentre os mais significativos, foi realizada uma aula pública na Câmara de Vereadores de Ponta Grossa, com participação de professores, pesquisadores, ambientalistas, autoridades políticas e estudantes de escolas, colégios e universidades (Figura 3).

Importante ressaltar que mais de 40 músicos participaram voluntariamente da composição e gravação do single da campanha ${ }^{3}$, assim como personalidades que cederam sua imagem e aderiram à causa.

Figura 2: Slogan da campanha "Pare, Preste Atenção" e logomarca do movimento.

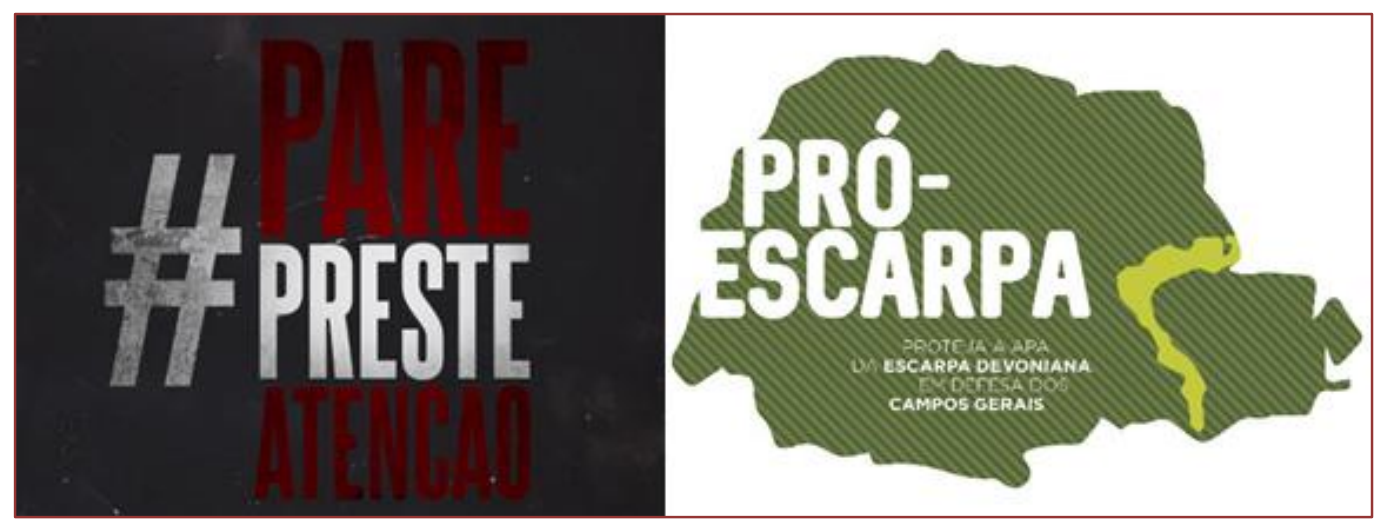

Fonte: https://www.justicaeco.com.br

Figura 3: Aula pública na Câmara de Vereadores de Ponta Grossa.

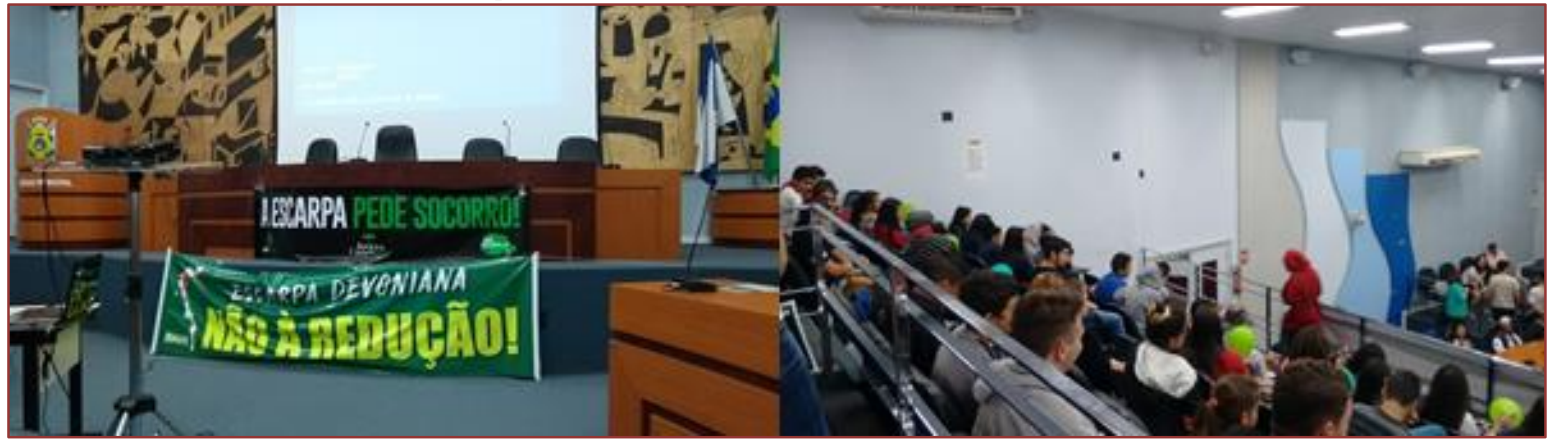

Fonte: os autores

\footnotetext{
2 Para mais informações consultar: https://www.justicaeco.com.br/musica-em-defesa-da-maior-area-de-protecaoambiental-do-sul-do-brasil-viraliza-e-supera-um-milhao-de-visualizacoes-em-duas-semanas/

3 Para mais informações consultar: https://www.bemparana.com.br/noticia/musicos-se-unem-em-defesa-daescarpa-devoniana--\#.XyB2DZ5KjIU
} 
Por meio de um site criado para a campanha, a sociedade foi estimulada a enviar e-mails ao poder público estadual, totalizando 167 mil envios somente no primeiro semestre de 2018. Cedendo ao clamor da mobilização da sociedade, em outubro de 2018 o PL 527/2016 foi arquivado a pedido dos próprios deputados proponentes, com apoio unânime dos parlamentares da Assembleia Legislativa do Paraná.

Os fatos aqui apresentados abrem a perspectiva de discursos contemporâneos sobre a natureza, apresentados por Reigota (2010), ao afirmar que a biodiversidade atualmente ocupa uma posição de destaque na Educação Ambiental. Segundo o autor, o termo que antes era considerado um recurso natural, hoje em dia inclui componentes éticos, políticos e culturais, trazendo uma renovação temática e conceitual.

Este pressuposto atende diretamente à situação aqui discutida, quando a redução de uma área de proteção, e a consequente perda de biodiversidade, ganha importância na vida de cidadãos, estudantes, moradores da região e instituições de ensino e pesquisa. Ou seja: há um imaginário local atento à biodiversidade e a cultura da região. Para Feder e Matos (2019), trata-se do caminho para presenciar a instauração de um paradigma mais biocêntrico do que antropocêntrico.

Porém, este ainda é um caminho em construção. Reigota (2010) afirma que a Educação Ambiental deve colaborar com a formação dos cidadãos e a autonomia para participarem de debates públicos e exercitar seus direitos políticos. Neste sentido, deve haver diálogo com a bioética, pautado em conhecimentos aprofundados e processos dialógicos (e não dogmáticos) de forma que se construa uma sociedade sustentável e democrática.

Este processo pode ser observado na prática, quando as questões relacionadas à APA da Escarpa Devoniana deixam de ser tratadas como acadêmicas e passam a ser um campo plural e diferenciado que, segundo Lima (2009), reúne contribuições de diversas disciplinas científicas, matrizes filosóficas, posições político-pedagógicas, atores e movimentos sociais.

Amaral et al. (2018), analisando processos de formação em Educação Ambiental, reforçam este raciocínio ao afirmar que na atualidade é imprescindível não somente teorizar sobre os problemas ambientais, mas também criar e aplicar dispositivos interventivos e práticas que permitam avançar na resolução destes. Para os autores, compreende uma construção de concepções que vão desde a conscientização dos sujeitos, percorrendo um trajeto de mobilização, manifestação (em que a teoria influencia a prática e vice-versa) e existe um movimento contínuo de desconstrução e criação.

Para Saito (2002), promover a sensibilização das pessoas, reestabelecer a ligação homem-natureza e estimular a sua proteção já não bastam mais para a tomada de decisões acerca dos problemas ambientais. A degradação causada pela utilização até o esgotamento dos recursos naturais e o modo de vida orientado pelo consumismo desenfreado, exigem abordagens mais ativistas em educação que visem transformar as relações entre sociedade, ser humano e natureza. Ou seja: requer mobilização.

Castell (2013) aponta o quanto as mobilizações, quando tomam o espaço urbano, caminham junto com uma espontaneidade latente, como observado durante a audiência pública ocorrida em março de 2017. Percebe-se que a existência de um imaginário, que estabelece uma ligação histórica e cultural com a APA, permitiu que a mobilização, durante a audiência pública, tivesse um impacto nas ações que se instauraram.

No entendimento de Toro (1996), mobilizar consiste em convocar voluntários para um propósito de interpretação e sentidos compartilhados. Compreende um tipo de atividade compartilhada diferente de qualquer tipo de manipulação ou chantagem, visto que é um ato de liberdade que só ocorre se existe participação consciente e espontânea dos sujeitos envolvidos. Para o autor, a mobilização só se torna concreta quando atende três condições: (i) a existência de um propósito preciso que corresponda às expectativas e percepções do grupo; (ii) a existência de pessoas qualificadas atuando como multiplicadoras; e (iii) a coletivização das práticas.

Analisando a questão da manifestação contrária ao PL 527/2016, se reconhece que o propósito de conservação da APA da Escarpa Devoniana atende à percepção de todo o grupo envolvido. Assim, nota-se que o movimento ambientalista organizado ao redor desta questão obteve êxito. Este tipo de situação já vem ocorrendo há alguns anos em diversas situações no mundo todo. Castells (2013) afirma que mais do que força social, há capacidade de adaptação às condições de comunicação e mobilização apresentadas pelo novo paradigma tecnológico. Para o autor, junto a isso, há também o elemento emocional, que como catalisador, pode ampliar a mobilização, com a utilização da tecnologia. Desta forma, pode-se afirmar que as mídias digitais foram significativas para que a mobilização fosse ampliada para além dos municípios que abrigam a APA. 
Para Mochiutti e Guimarães (2018), é um desafio de comunicação fazer chegar à sociedade a real importância da biogeodiversidade e a necessidade de sua preservação. Há que se destacar aqui a atuação das organizações não governamentais (ONGs) que são formadas por pessoas da sociedade civil, sem influências partidárias. No caso do PL 527/2016, o OJC teve um papel fundamental desde o início do processo, buscando disseminar conhecimento científico sobre o tema, permitindo que a população formasse opinião coerente sobre os fatos. As chamadas "fake news", notícias falsas que costumam ser disseminadas sobre temas importantes foram derrubadas uma por uma com argumentos coerentes.

A conjunção desses fatos contribuiu para evidenciar a inconstitucionalidade do PL e os proponentes recuaram devido à pressão popular. A razão pela qual essa questão se configura, se aproxima do que apontam Feder e Mattos (2019) a respeito do princípio de participação e informação, atrelado à necessidade de realização de audiências públicas, assegurando não somente o conhecimento e a participação da população, mas inserindo a sociedade no contexto dos debates relacionados ao meio ambiente, destacando a efetividade da realização e participação da sociedade na audiência pública realizada em 2017, em Ponta Grossa/PR, como início da mobilização social que se estendeu e se fortaleceu enquanto o PL tramitou por Comissões parlamentares na Assembleia Legislativa do Paraná.

\section{CONSIDERAÇÕES FINAIS}

A mobilização social foi fundamental para a defesa da APA da Escarpa Devoniana. As ONGs tiveram papel singular em conduzir as discussões e apresentar fatos sem influências partidárias, diferentemente do que estava ocorrendo na Assembleia Legislativa, por influência partidária e sob efeito coercitivo dos agentes do agronegócio situados nos limites da Área.

No relato aqui apresentado, o OJC teve um papel fundamental desde o início do processo, buscando disseminar conhecimento científico construído sobre o tema, permitindo que a população formasse opinião coerente sobre os fatos. As notícias falsas que costumam ser disseminadas, muitas vezes intencionalmente, sobre temas importantes, foram derrubadas uma por uma com argumentos coerentes, apresentados de forma clara e transparente à sociedade.

Os cidadãos, a partir do momento que se encontram munidos desses conhecimentos e argumentos, compreendendo os riscos envolvidos na aprovação do PL 527/2016, se sentiram confiantes em expressar seu posicionamento, indo além dos motivos culturais e da ligação sentimental com o patrimônio natural da região dos Campos Gerais. Tornaram-se cidadãos conscientes, parte responsável do processo.

De posse desta responsabilidade, a atuação e a rede de ação que se desenvolveu - escolas e universidades, Câmaras de vereadores, artistas, pesquisadores, imprensa, as ONGs foram múltiplas, e acionais. Para além da defesa da institucionalidade da APA, essa rede acional atingiu o cotidiano e o imaginário local e as emoções. Catalisador e aglutinador, deu vazão ao sentimento de pertencimento e responsabilidade sobre a conservação da APA.

Essas mobilizações, nos cenários complexos que envolvem a questão ambiental, convertem ações difusas em mobilizações conscientes. A mobilização em defesa da APA, nos Campos Gerais, demonstrou que esse imaginário, ao se converter em ação efetiva, política cultural e organizativa, configurou processos de formação da consciência ambiental e, portanto, cidadã.

\section{REFERÊNCIAS}

[1] AMARAL, Augusto Luis Medeiros; GENTINI, Alfredo Guillermo Martin; AMARAL, Raquel Avila. Grupo como dispositivo: a microintervenção ecosófica nos processos de formação em educação ambiental. Educação e Pesquisa, São Paulo, v. 44, 2018. Disponível em:

http://www.scielo.br/scielo.php?script=sci_arttext\&pid=S151797022018000100438\&lng=pt\&nrm=iso. Acesso em: 03 dez. 2020.

[2] ANTIQUEIRA, Lia Maris Orth Ritter. Lugar de aluno é na audiência pública sim! Bem Paraná. 2017 a. Disponível em: http://www.bemparana.com.br/noticia/496446/lugar-de-aluno-e-na-audiencia-publica-sim. Acesso em: 03 dez. 2020.

[3] ANTIQUEIRA, Lia Maris Orth Ritter. APA da Escarpa Devoniana: uma verdadeira sala de aula. O ECO. 2017b. Disponível em: http://www.oeco.org.br/colunas/colunistas-convidados/apa-da-escarpa-devoniana-uma-verdadeirasala-de-aula/. Acesso em: 03 dez. 2020. 
[4] BRASIL. Senado Federal. Constituição Federal. Promulgada em 5 de outubro de 1988. Disponível em: http://www.planalto.gov.br/ccivil_03/constituicao/ constituição.htm. Acesso em: 03 dez. 2020.

[5] CASTELLS, Manuel. Redes de indignação e esperança: movimentos sociais na era da internet. Rio de Janeiro: Zahar, 2013

[6] DIARIO DOS CAMPOS. Movimento protesta contra redução da APA da Escarpa Devoniana. Diário dos Campos. 2017. Disponível em: http://www.diariodoscampos.com.br/ cidades/2017/06/movimento-protesta-contrareducao-de-apa-da-escarpa-devoniana/2383338/. Acesso em: 03 dez. 2020.

[7] FEDER, Marcela Macedo; MATTOS, Mariana Maria de Carvalho. Análise do Projeto de Lei Estadual n 527 - É constitucional a Alteração da Área de Proteção Ambiental da Região da Escarpa Devoniana? Revista dos Estudantes Direito UFES - REDUFES, v. 1, n. 1, 2019. Disponível em: https://periodicos.ufes.br/redufes/article/view/23356. Acesso em: 03 dez. 2020.

[8] LIMA, Gustavo Ferreira da Costa. Educação ambiental crítica: do socioambientalismo às sociedades sustentáveis. Educação e Pesquisa. São Paulo, v. 35, n. 1, p. 145-163, 2009. Disponível em: https://www.scielo.br/pdf/ep/v35n1/a10v35n1.pdf. Acesso em: 03 dez. 2020.

[9] MILAN. Elizana. Ecótonos campo-floresta na Área de Proteção Ambiental da Escarpa Devoniana, Campos Gerais do Paraná, Brasil. Orientadora: Rosemari Moro. 2014. 91 f. Dissertação (Mestrado em Gestão do Território) Universidade Estadual de Ponta Grossa, Ponta Grossa, 2014. Disponível em: https://tede2.uepg.br/jspui/handle/prefix/627. Acesso em: 03 dez. 2020.

[10] MOCHIUTTI, Nair Fernanda Burigo; GUIMARÃES, Gilson Burigo. A comunicação para a conservação: o caso do movimento em prol da APA da Escarpa Devoniana (Paraná, Brasil). Terræ Didatica, 14(4):455-462, 2018. Disponívem el: http://www.ige.unicamp. br/terraedidatica/. Acesso em: 03 dez. 2020.

[11] PARANÁ. Conselho Municipal de Meio Ambiente de Ponta Grossa. Diário Oficial do Município. Edição 2078, 2017. Disponível em: http://www.pontagrossa.pr.gov.br/files/diario-oficial/2017-06-020-ed2078.pdf. Acesso em: 03 dez. 2020.

[12] PARANÁ. Assembleia Legislativa. Decreto Estadual número 1231, de 27 de março de 1992. Institui a Área de Proteção Ambiental denominada APA da Escarpa Devoniana. Disponível em: http://www.iap.pr.gov.br/arquivos/File/Plano_de_Manejo/APA_Escarpa_Devoniana/anexos/1_Decreto_n_1231_27_ marco_1992.pdf. Acesso em: 03 dez. 2020.

[13] PARANÁ. Assembleia Legislativa. Projeto de Lei número 527, de 07 de novembro de 2016. Altera os limites da APA da Escarpa Devoniana. Disponível em:

http://portal.alep.pr.gov.br/index.php/pesquisalegislativa/proposicao?idProposicao=66840. Acesso em: $03 \mathrm{dez}$. 2020.

[14] PARANÁ. Secretaria de Estado da Cultura. Autos 08/2012. Termo de Abertura de Processo para tombamento da área denominada APA da Escarpa Devoniana. Disponível em: http://www.patrimoniocultural.pr.gov.br/arquivos/ File/Leis_e_Decretos/Documentos_do_Processo_de_Tombamento_da_Escarpa_Devoniana_30_jun_2015.PDF. Acesso em: 03 dez. 2020.

[15] PRIMACK, Richard; RODRIGUES, Efraim. Biologia da conservação. Londrina: Vida, 2001.

[16] REIGOTA, Marcos. A Educação Ambiental frente aos desafios apresentados pelos discursos contemporâneos sobre a natureza. Educação e Pesquisa. São Paulo, v. 36, n. 2, p. 539-570, 2010. Disponível em: https://www.scielo.br/pdf/ep/v36n2/a08v36n2.pdf. Acesso em: 03 dez. 2020.

[17] SAITO, Carlos Hiroo. Política Nacional de Educação Ambiental e construção da cidadania: desafios contemporâneos. In: RUSHEINSKY, Aloisio (Org.). Educação ambiental: abordagens múltiplas. Porto Alegre: Artmed; 2002. p. 47-72.

[18] TORO, José Bernardo. Mobilização social: uma teoria para universalização da cidadania. In: MONTORO, Tania Siqueira. (Cord.). Comunicação e mobilização social. Brasília: UnB, 1996, p. 26 a 40. 


\section{Capítulo 4}

Evolução temporal do uso e ocupação do solo no município de Teixeira de Freitas, Bahia

\section{Emilly da Silva Farias \\ Joscélia Monteiro Santos de Brito \\ Raquel Viana Quinelato \\ João Batista Lopes da Silva \\ Laylane Pinheiro Alves}

Resumo: 0 processo de substituição de áreas de vegetação nativa por culturas antrópicas vem se intensificando desde o início da ocupação da região do extremo sul da Bahia, sendo motivo para preocupação em relação a forma de ocupação das regiões de Mata Atlântica. Assim, objetivou-se com este trabalho identificar a alteração do uso e ocupação do solo entre os anos de 1990 e 2018 no município de Teixeira de Freitas. Para avaliação do uso do solo foram utilizados os dados de uso e ocupação disponibilizados pelo Fórum Florestal do Extremo Sul da Bahia para os anos de 1990, 1994, 2002, 2006, 2013 e 2018. As imagens foram classificadas utilizando o método de classificação automática supervisionada com visita a campo, e posterior cálculo do índice Kappa para validação. A partir dessas imagens, foram gerados mapas de uso e ocupação do solo para cada ano estudado por meio da utilização do software QGIS. Com base nos resultados, é possível observar a redução significativa das áreas de vegetação nativa em virtude do aumento das áreas de culturas antrópicas, principalmente a pecuária e a silvicultura. Portanto, torna-se necessário a adoção de práticas de manejo e políticas públicas a fim de equilibrar os objetivos econômicos com os prejuízos ambientais.

Palavras-chave: Geoprocessamento; Mata Atlântica; Vegetação Nativa; Pecuária; Silvicultura. 


\section{INTRODUÇ̃̃O}

O município de Teixeira de Freitas está localizado no Território de Identidade do Extremo Sul da Bahia e atualmente apresenta áreas reduzidas de vegetação nativa, dispersas entre áreas de cultivos agropecuários e áreas urbanas, que segundo Ribeiro et al. (2011) são características frequentemente observadas no bioma Mata Atlântica.

Sabe-se que atividades agropecuárias, agrícolas e florestais são viáveis economicamente, especialmente para a exploração do eucalipto no Extremo Sul da Bahia, entretanto, tais atividades são grandes responsáveis pelo processo desordenado de substituição da vegetação nativa e, consequentemente podem afetar tanto a quantidade, quanto a qualidade dos recursos hídricos, ar, solo e promover a diminuição de habitats e a biodiversidade da fauna e da flora (BITTENCOURT, 2009; FAO, 2013).

Uma vez que os usos e ocupações do solo impactam de forma direta e indireta as características ambientais e sociais dos municípios, e sendo o seu mapeamento e monitoramento técnicas eficazes para conhecer e mitigar os danos ambientais atuais e futuros, objetiva-se com este trabalho identificar a alteração do uso e ocupação do solo entre os anos de 1990 e 2018 no município de Teixeira de Freitas, Bahia.

\section{METODOLOGIA}

O município de Teixeira de Freitas está localizado na região do Extremo Sul Baiano sob as coordenadas: latitude $17^{\circ} 32^{\prime} 06^{\prime \prime} \mathrm{S}$ e longitude $39^{\circ} 44^{\prime} 31^{\prime \prime} 0$. 0 município possui área estimada em $1.165 \mathrm{~km}^{2} \mathrm{e}$ população de 160.487 habitantes em 2019 (IBGE, 2020).

Para avaliação do uso do solo foram utilizados os dados de uso e ocupação disponibilizados pelo Fórum Florestal do Extremo Sul da Bahia para os anos de 1990, 1994, 2002, 2006, 2013 e 2018. As imagens utilizadas na classificação foram entre 1990 e 2006 da plataforma Landsat 5, sensor TM, enquanto 2013 foram utilizadas imagens RapidEye e 2018 imagens Spot. As imagens foram classificadas utilizando o método de classificação automática supervisionada com visita a campo e, posterior cálculo do índice Kappa para validação.

A análise temporal do período de estudo (1990 a 2018) foi realizada a partir da comparação dos mapas de uso e ocupação do solo e das áreas ocupadas pelas 14 classes analisadas, verificando-se assim, as mudanças ocorridas em cada período. Para todas as etapas citadas, bem como para a elaboração dos mapas, foi utilizado o software livre de informações geográficas QGIS 3.4®.

\section{RESULTADOS E DISCUSSÃO}

O município de Teixeira de Freitas é ocupado em sua maior parte pelas classes de pastagens, que juntas, pasto limpo e pasto sujo, correspondem a $62,91 \%$ da área total do município, tendo crescido $68,2 \mathrm{~km}^{2}$ entre os anos de 1990 e 2018, equivalente a uma taxa de crescimento de 10,4\% (tabela 1). 
Tabela 1. Classes de uso e ocupação do solo, em $\mathrm{km}^{2}$ e \%, do município de Teixeira de Freitas, durante o período de 1990 a 2018

\begin{tabular}{|c|c|c|c|c|c|c|c|c|c|c|c|c|}
\hline \multirow{2}{*}{ Classes } & \multicolumn{2}{|c|}{1990} & \multicolumn{2}{|c|}{1994} & \multicolumn{2}{|c|}{2002} & \multicolumn{2}{|c|}{2006} & \multicolumn{2}{|c|}{2013} & \multicolumn{2}{|c|}{2018} \\
\hline & $\mathrm{km}^{2}$ & $\%$ & $\mathrm{~km}^{2}$ & $\%$ & $\mathrm{~km}^{2}$ & $\%$ & $\mathrm{~km}^{2}$ & $\%$ & $\mathrm{~km}^{2}$ & $\%$ & $\mathrm{~km}^{2}$ & $\%$ \\
\hline $\mathrm{AV}$ & 5,8 & 0,5 & 5,8 & 0,5 & 6,0 & 0,5 & 7,8 & 0,7 & 11,6 & 1,0 & & - \\
\hline AU & 15,0 & 1,3 & 16,5 & 1,4 & 19,9 & 1,7 & 24,1 & 2,1 & 32,5 & 2,8 & 29,9 & 2,6 \\
\hline $\mathrm{AF}$ & 9,1 & 0,8 & 9,1 & 0,8 & 8,8 & 0,8 & 6,3 & 0,5 & 1,9 & 0,2 & 3,1 & 0,3 \\
\hline $\mathrm{AG}$ & 40,3 & 3,5 & 115,0 & 10,0 & 250,2 & 21,7 & 23,6 & 2,0 & 56,8 & 4,9 & 46,7 & 4,0 \\
\hline CA & 232,1 & 20,1 & 230,6 & 20,0 & 223,8 & 19,4 & 210,9 & 18,3 & 142,9 & 12,4 & 31,2 & 2,7 \\
\hline EU & 16,9 & 1,5 & 12,8 & 1,1 & 28,6 & 2,5 & 223,1 & 19,3 & 178,0 & 15,4 & 181,3 & 15,7 \\
\hline FI & 95,6 & 8,3 & 66,0 & 5,7 & 26,5 & 2,3 & 10,6 & 0,9 & 4,1 & 0,4 & 33,4 & 2,9 \\
\hline FM & 73,4 & 6,4 & 41,2 & 3,6 & 114,2 & 9,9 & 30,3 & 2,6 & 56,3 & 4,9 & 93,1 & 8,1 \\
\hline IR & 0,3 & 0,0 & 0,3 & 0,0 & 0,6 & 0,1 & 1,3 & 0,1 & 10,9 & 0,9 & 1,5 & 0,1 \\
\hline $\mathrm{CH}$ & 3,8 & 0,3 & 3,8 & 0,3 & 3,8 & 0,3 & 4,2 & 0,4 & 3,0 & 0,3 & 5,6 & 0,5 \\
\hline PL & 49,5 & 4,3 & 18,9 & 1,6 & 103,1 & 8,9 & 101,4 & 8,8 & 381,6 & 33,1 & 587,3 & 50,9 \\
\hline PS & 607,8 & 52,7 & 630,0 & 54,6 & 364,7 & 31,6 & 505,9 & 43,9 & 238,9 & 20,7 & 138,1 & 12,0 \\
\hline SV & 3,0 & 0,3 & 3,0 & 0,3 & 2,9 & 0,3 & 3,2 & 0,3 & & - & 2,2 & 0,2 \\
\hline SE & & - & & - & & - & 0,4 & 0,0 & 34,5 & 3,0 & & - \\
\hline
\end{tabular}

Em que: AF - Afloramento rochoso; AG - Agricultura; AU - Área Urbana; AV - Áreas Úmidas/Várzea; CA - Comunidade Aluvial Arbórea; EU - Eucalipto; FI - Floresta Estágio Inicial; FM - Floresta Estágio Médio/Avançado; IR - Instalações Rurais; CH - Corpos Hídricos; PL - Pasto Limpo; PS - Pasto Sujo; SV - Sistema Viário; e SE - Solo Exposto.

Apesar de não ocupar grandes extensões do município em questão, a cultura do Eucalipto apresentou a maior taxa de crescimento entre os anos do estudo, correspondendo a 975,7\% de aumento, passando de $16,9 \mathrm{~km}^{2}$ em 1990, para 181,3 km² em 2018. Em relação as áreas de vegetação nativa, consideradas nesse estudo as classes Comunidade Aluvial Arbórea, Floresta Estágio Inicial e Floresta Estágio Médio, ao longo dos anos analisados, apresentaram juntas uma taxa de redução de $60,7 \%$, equivalente a $243,4 \mathrm{~km}^{2}$ (figura 1).

Figura 1. Classes de uso e ocupação do solo do município de Teixeira de Freitas, Bahia

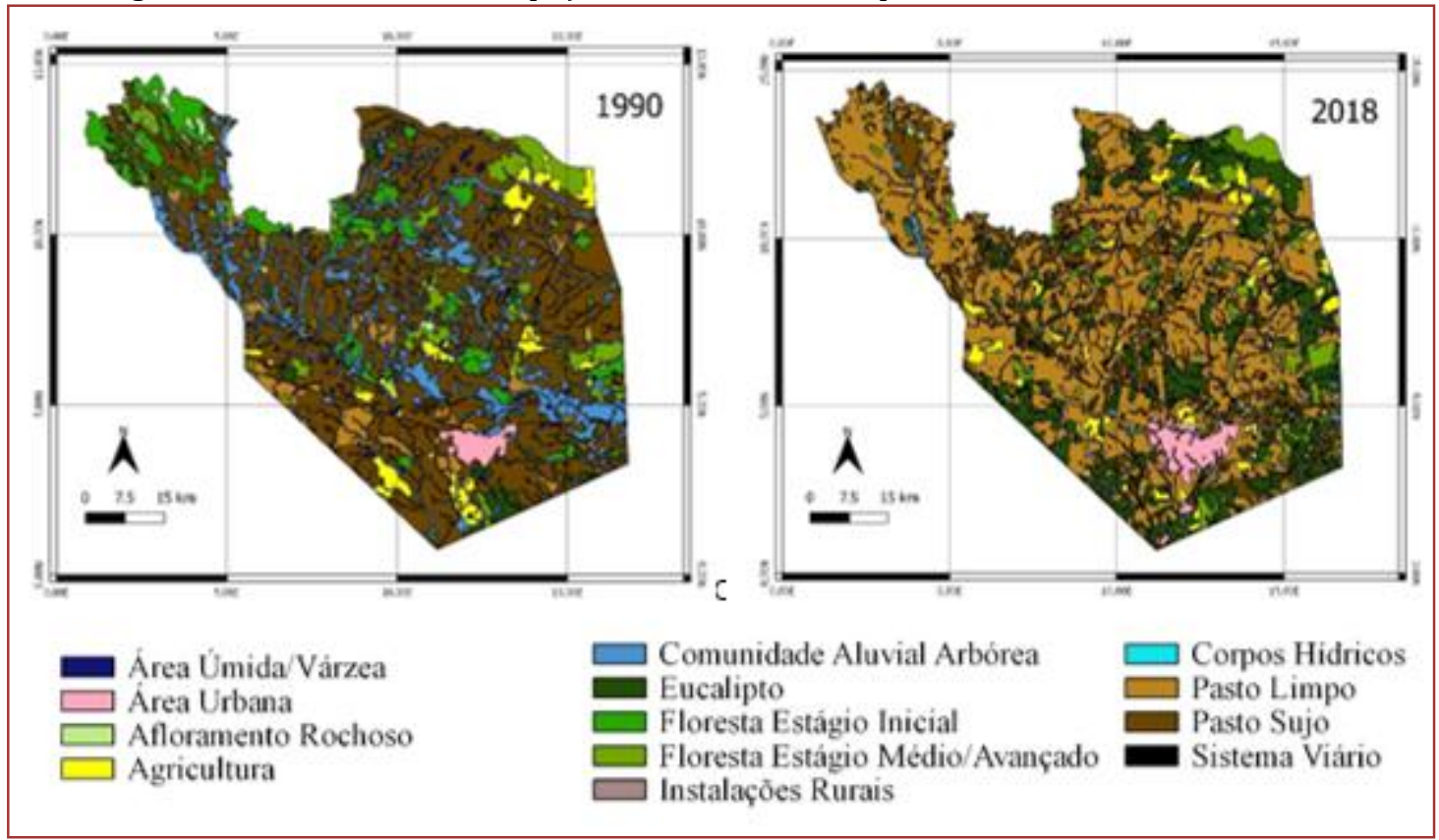


Diante do cenário apresentado, acredita-se que a redução significativa das áreas de vegetação nativa esteja diretamente relacionada ao aumento das áreas de culturas antrópicas, como a pecuária e a silvicultura. Cenário similar também foi observado no estudo realizado por Araújo Neto et al. (2017), no vale do rio Trussu - Ceará, onde foi visto que as atividades antrópicas passaram a ocupar 40,7\% da área estudada, gerando uma redução de $38,7 \%$ para $11,2 \%$ das áreas florestais para uso em atividades humanas como agricultura, pastoreio e urbanização.

Em relação aos danos causados pelas extensas áreas de pastagens, tem-se como alternativa de mitigação os sistemas agroflorestais nas suas diferentes modalidades, podendo promover a proteção da vegetação nativa, conservação dos solos e dos recursos hídricos, além de propiciar o sequestro de carbono, o aumento da biodiversidade e o desenvolvimento socioeconômico da região (KICHEL et al. 2019). Em termos econômicos, a adoção dos sistemas agroflorestais permite que sejam cultivados diferentes produtos, como leguminosas, grãos, fibras, carne, leite e agroenergia. Deste modo, as atividades nas propriedades rurais podem ser diversificadas garantindo maior produtividade e lucratividade (MBOW et al., 2014; MEIJERA et al., 2015).

\section{CONSIDERAÇÕES FINAIS}

O munícipio de Teixeira de Freitas é ocupado predominantemente por culturas antrópicas, principalmente a pecuária e a silvicultura (que embora ocupem áreas ainda pequenas, tem apresentado alta taxa de crescimento). Logo, se faz necessário que o poder público intervenha para que empresas responsáveis por cultivos comerciais, implantem plano de manejo adequado, garantindo o equilíbrio econômico e ambiental, sem esquecer da relevância socioeconômica que essa cultura representa para a população local.

\section{REFERÊNCIAS}

[1] ARAUjO NETO, J. R.; ANDRADE, E. M.; PALÁCIO, H. A. Q.; SALES, M. M.; MAIA, A. R. S. Influence of land use/occupation on water quality in the Trussu river valley, Ceará, Brazil. Revista Ciência Agronômica, v. 48, n. 1, p. 59$69,2017$.

[2] BITTENCOURT, M. V. L. Impactos da agricultura no meio-ambiente: Principais tendências e desafios (Parte 1). Revista Economia \& Tecnologia, Curitiba, v.5, n.3, p. 133-146, 2009.

[3] FOOD AND AGRICULTURE ORGANIZATION OF UNITED STATIONS, FAO. Livestock and Environment, 2013. Disponível em: <http://www.fao.org/ag/againfo/themes/en/Environment.html>. Acesso em: 10 nov. 2019.

[4] INSTITUTO BRASILEIRO DE GEOGRAFIA E ESTATÍSTICA, IBGE. Panorama [Internet]. Disponível em: <https://cidades.ibge.gov.br/ >. Acesso em: 20 jun. 2020.

[5] KICHEL, A. N.; BUNGENSTAB, D. J.; ZIMMER, A. H.; SOARES, C. O.; ALMEIDA, R. G. ILPF: Inovação com Integração de Lavoura, Pecuária e Floresta. Brasília, DF: Embrapa, 2019.

[6] MBOW, C.; SMITH, P.; SKOLE, D.; DUGUMA, L.; BUSTAMANTE, M. Achieving mitigation and adaptation to climate change through sustainable agroforestry practices in Africa. Current Opinion in Environmental Sustainability, v. 6, p. 8-14, 2014.

[7] MEIJERA, S. S.; CATACUTAN, D.; AJAYI, O. C.; SILESHI, G. W.; NIEUWENHUIS, M. The role of knowledge, attitudes and perceptions in the uptake of agricultural and agroforestry innovations among smallholder farmers in sub-Saharan Africa. International Journal of Agricultural Sustainability, v. 13, n. 1, p. 40-54, 2015.

[8] RIBEIRO, M. C.; MARTENSEN, A. C.; METZGER, J. P.; TABARELLI, M.; SCARANO, F.; FORTIN, M. J. The Brazilian Atlantic Forest: a shrinking biodiversity hotspot. In: Zachos FE, Habel JC, editores. Biodiversity hotspots: distribution and protection of conservation priority areas. Heidelberg: Springer; 2011. 


\section{Capítulo 5}

\section{Biopirataria: Impacto socioambiental no Brasil}

\section{Amanda Cerqueira dos Santos}

\section{Eduarda Cristina Da Vinha}

Mayara dos Santos Pereira

Wilton Silva de Souza

Bárbara Maria Borges Ribeiro

Resumo: Sabe-se que o Brasil é um dos países com a maior biodiversidade biológica do planeta. A sua vasta riqueza faz com que seja alvo constante de biopirataria, com alta relevância financeira. Neste sentido, o objetivo do trabalho é demonstrar os recursos naturais da fauna e da flora, que sofrem e já sofreram com este ato de exploração ilegal. Para isso foram realizadas buscas literárias sobre o tema Biopirataria, em plataformas do Google acadêmico e sites de ONGs. Foi observado que dentre todos os biomas brasileiros, a Amazônia é a mais afetada por ser detentora da maior parte da fauna e da flora que são diariamente alvo dos praticantes assíduos da Biopirataria, devida à falta de uma legislação penal rígida aos praticantes deste ato ilícito.

Palavras-chave: Biopirataria; Amazônia; Biodiversidade; Impactos Ambientais. 


\section{INTRODUÇÃO}

O Brasil é considerado o país com a maior diversidade biológica do planeta, com cerca de $22 \%$ das espécies nativas mundiais. A vasta riqueza vegetal e animal faz com que o Brasil seja alvo constante de Biopirataria (GOMES, 2007). Além da relevância financeira do bioma brasileiro, que desperta o interesse pela busca por material genético para desenvolvimento de produtos diversos, como medicamentos e cosméticos (VALÉRIO et al.,2010), a inexistência de um ordenamento legal para regulamentar o acesso à biodiversidade brasileira, de uma tipificação legal de criminalização da Biopirataria, e diante das possibilidades do esgotamento dos recursos naturais, são fatores que estimulam a Biopirataria no Brasil (VALÉRIO et al.,2010).

A Biopirataria é utilizada para explicar a manipulação ilegal das diversas formas de vidas encontradas no meio ambiente, sendo tratada como crimes contra o Meio Ambiente (ALVEZ,2007). E, ao contrário de outras formas de contrabando ou reprodução ilegal de conhecimentos sem autorização de seus proprietários ou detentores, a Biopirataria não é caracterizada como ilícito criminal, mas apenas administrativo, com aplicação de multas que, excepcionalmente, são recolhidas pelo infrator (GOMES, 2007).

Com avanço da biotecnologia e a fragilidade dos marcos legais de proteção da biodiversidade, expõem perigosamente o conhecimento tradicional a ações de Biopirataria (IZIQUE,2002). Sendo assim, nosso patrimônio genético é colocado em risco, sendo levado de forma clandestina, e sem proteção legal, ou, qualquer quantia e/ou sem autorização, do Brasil e do Estado do Amazonas (POZZETTI; MENDES,2014). Os recursos vegetais com maior interesse econômico seriam as plantas medicinais, aromáticos, inseticidas e corantes naturais. E durante as tentativas dos exploradores de levar as sementes por diversas vezes e não terem êxito, se infiltraram nas comunidades indígenas e ribeirinhas, para adquirir os conhecimentos acerca de como conservar as sementes por longo tempo. Assim, levaram não só os recursos vegetais, mas o saber das populações tradicionais da Amazônia (POZZETTI; MENDES,2014). A Biopirataria da fauna é para fins científicos, fornecendo substâncias que promovem uma base à pesquisa e à produção de medicamentos. Esta modalidade movimenta altos valores, como por exemplo, o veneno da aranhaarmadeira, Phoneutria sp, que foi estudada para dar origem a um analgésico eficaz (COUTINHO,2001; apud Rel. RENCTAS 2001).

0 potencial da biodiversidade precisa ser transformado em algo concreto, no qual há necessidade de conexão com identificação, seleção de variedades de interesse produtivo, domesticação, plantio e industrialização. Os acervos botânicos das instituições de pesquisa regionais precisam transformar os recursos da biodiversidade econômica, colocando a serviço de geração de renda e emprego, pois é a melhor forma de combater a Biopirataria na Amazônia. Para isso, é necessário identificar os recursos genéticos, analisar seus componentes, proceder a sua domesticação, a produção em bases racionais e a verticalização na região. Pois, a fragilidade da economia extrativa em que se baseia a maioria dos produtos da biodiversidade amazônica constitui um convite à Biopirataria (HOMMA,2005).

Diante do apresentado, objetiva-se com esse trabalho demonstrar os recursos naturais da fauna e da flora que sofrem e já sofreram com este ato de exploração ilegal.

\section{METODOLOGIA}

Para o desenvolvimento do trabalho, fez-se uma busca literária sobre Biopirataria da flora e fauna brasileira, utilizando as palavras-chaves: Biopirataria; Amazônia; Biodiversidade; Impactos Ambientais. Consideraram-se publicações dos últimos 20 anos (de 2000 a 2020), utilizando a base de dados do Google Acadêmico; e relatório de ONGs como a RENCTAS.

\section{RESULTADOS E DISCUSSÃO}

Diversos autores buscaram entender o motivo do aumento da prática Biopirataria, analisando a fiscalização, leis, tecnologias, investimentos, considerando as questões de extensão territorial e socioeconômica do país. Eles mostram que a falta de tipificação penal dos crimes de Biopirataria, dificulta o combate a esta guerra contra o ilícito ambiental. Países como a Alemanha evidenciam que o combate contra esta prática é bem-sucedida quando este igualmente apresenta a natureza de infração penal. Além da legislação, também é perceptível a falta de uma política ocupacional do território, de modo que ocorra preservação do ambiente e uma exploração de forma sustentável. 
O Quadro 1 apresenta algumas espécies que são alvo de Biopirataria no Brasil, as que mais sofrem com essa prática são representantes da flora, por causa da sua vasta utilidade como: na indústria farmacêutica, alimentícias e práticas culturais. Em relação à fauna, o extravio se dá, principalmente, para fabricação de novos medicamentos, feitos através de animais venenosos e outras espécies como animais de estimação.

Quadro 1-Espécies patenteados fora do Brasil

\begin{tabular}{|c|c|c|c|}
\hline Nome científico & Nome popular & Uso da substância & $\begin{array}{l}\text { Países que possuem } \\
\text { patente }\end{array}$ \\
\hline Theobroma galndiflorun & Cupuaçu & $\begin{array}{l}\text { Indústria alimentícias e } \\
\text { medicinal } 4\end{array}$ & EU, Inglaterra e Japão ${ }^{1}$ \\
\hline Carapa guianensis aubi & Andiroba & Cosmético e medicinal 4 & EU, EUA, França e Japão ${ }^{1}$ \\
\hline Copaifeira sp. & Copaíba & $\begin{array}{l}\text { Cosmético, medicinal e } \\
\text { combustível }{ }^{4}\end{array}$ & EU, França e WIPO ${ }^{1}$ \\
\hline Banisteripsi caapi & Ayahuasca & Bebidas $^{4}$ & EUA $^{1}$ \\
\hline Várias espécies & Curare & $\begin{array}{l}\text { Medicinal e armamento } \\
\text { indígena } 4\end{array}$ & Inglaterra e EUA ${ }^{1}$ \\
\hline Aniba rosaedora & Pau-de-rosa & Cosmético $^{2}$ & Europa e EUA 5 \\
\hline Pilocarpus jaborandi & Jaborandi & Medicinal $^{5}$ & $\begin{array}{l}\text { EUA, Itália, Rússia e entre } \\
\text { outros } 1\end{array}$ \\
\hline Euterpe precatoria & Açaí & $\begin{array}{l}\text { Indústria alimentícias e } \\
\text { medicinal } 4\end{array}$ & Alemanha, EUA e Japão 4 \\
\hline Chinchona afficinalis & Quinina & Medicinal ${ }^{4}$ & Inglaterra 4 \\
\hline Rã Phillomedisa bicolor & Sapo Kambô & Medicinal $^{4}$ & EU, EUA e Japão ${ }^{4}$ \\
\hline Bothrops jararaca & Jararaca & Medicinal $^{3}$ & EUA $^{3}$ \\
\hline
\end{tabular}

Fonte: 1HOMMA, 2005 Adaptado; 2ALENCAR Et.Al, 2008; 3OLIVEIRA Et.Al;4 MEDINA Et.Al;5 GALDINO

Mesmo que as pesquisas brasileiras tenham melhorado sua qualidade, instituições brasileiras de pesquisas vêm estudando fármacos e químicos, na tentativa de revelar medicamentos, fitoterápicos, cosméticos, porém, ainda faltam recursos financeiros. Devido a isso, diversos países internacionais, estudam e sabem suas existências, antes que os pesquisadores brasileiros, e com isso, o Brasil perde o seu direito de usá-la e patentear, pois já possuem patentes estrangeiras (QUEROZ et al., 2020).

Casos como este, o Theobroma grandiflorum, mais conhecido como cupuaçu, este fruto de origem amazônica, tem a sua polpa podendo ser usada para preparo de alimentos como: bolos, sucos, geleias; através de um processamento nas semente, se obtém como produto o "cupulate", que se assemelha ao chocolate. Todavia foi patenteado por uma empresa japonesa (Ashi Foods), podendo ser usada como marca na União Europeia, Japão e Estados Unidos. Mais tarde, pelo Escritório de Patentes japonês, anulouse esse registro, após recurso contra a aprovação da patente (YANAI et al., 2010).

Outro caso famoso de biopirataria, foi do veneno da jararaca da espécie Bothrops jararaca. Existe indícios que foi descoberto por brasileiro, mas que foi registrado e patenteado por uma empresa americana (Squibb) (FERNANDES, 2017). Descobriu-se que seu veneno da Jararaca potencializava a produção da substância. No ano de 1960, ela serviu de base para o desenvolvimento de Captopril, um medicamento utilizado para tratamento da hipertensão, casos de insuficiência cardíaca. (GOMES; SAMPAIO, 2019).

Outro caso de biopirataria: a Copaifeira sp, conhecida como Copaíba, é uma espécie de planta que possui estudos ligados à ciência a etnobotânica. (Rosa et al.,2009).Seu óleo extraído do tronco da árvore, podendo ser usado para fins medicinais, indicado para doenças como gonorreia, bronquite, dores em geral, antisséptico, (VARGAS et al., 2015) para cicatrização de cortes na pele; usado como combustível de lamparina, usado na calafetação do casco de pequenas embarcações.(Rosa et al.,2009). Em 2002, foi divulgado que o óleo tinha alto poder de antibiótico e anti-inflamatório, estaria sendo pesquisado por uma indústria alemã, podendo resultar em um novo antibiótico (FILHO, 2003 apud VARGAS et al., 2015).

Há também o sapo Phyllomedusa bicolor, encontrado na Amazônia, e é caracterizado pela sua utilização na medicina tradicional de alguns povos indígenas. Suas secreções são bem utilizadas pelos povos indígenas, onde são causadas intencionalmente lesões nos braços e pernas, aplicando posteriormente a secreção. (LIMA et al., 2019). Estudos realizado na secreção cutânea desta espécie de rã, criou-se vários produtos farmacológico. Entre as doenças tratada estão o Mal de Parkinson, AIDS, câncer e depressão, também usados em composto analgésico, fortalecimento do sistema imunológico. Seu registro aparece em torno de dez patentes espalhadas entre Estados Unidos, União Europeia e Japão (MEDINA; ALMEIDA, 2020). 
Diante deste presente artigo, os exemplos sobre algumas espécies que foram biopiratiadas, e mesmo que existem organizações coligadas a $\mathrm{ONU}$, que tenta proteger a biodiversidade brasileira, ainda há uma necessidade de uma legislação mais organizada e específica para esta prática ilícita, impedindo que empresas estrangeiras retirem as matérias-primas brasileiras, acarretando um prejuízo ao País. É de grande importância que este assunto fosse discutido em âmbito escolar, melhorar o acesso à educação ambiental, na tentativa de amenizar essas situações no futuro.

\section{CONCLUSÕES}

O Brasil é um dos países com maior biodiversidade do planeta, porém, não valoriza seus recursos. Sendo perceptível que, a maioria dos materiais retirados são para fins fitoterápicos, cosméticos, entre outros, mas, sem que ocorra um retorno financeiro ao País. No Brasil, ainda não apresenta uma tipificação penal congruente a quem praticar esse ato ou auxiliar esta prática. Falta uma legislação mais rígida que defenda a preservação da biodiversidade amazônica e que a exploração seja de maneira sustentável. E são necessários mais investimentos em pesquisas e proteção aos conhecimentos indígenas.

\section{AGRADECIMENTOS}

Agradecemos a Faculdade Integradas Einstein de Limeira, por nos oferecer o conhecimento necessário para realizar este artigo.

\section{REFERÊNCIAS}

[1] ALENCAR, Aline Ferreira de; DANTAS, Fernando Antônio de Carvalho; MINAHIM, Maria Auxiliadora. A NECESSIDADE DE TUTELA PENAL CONTRA A BIOPIRATARIA NA AMAZÔNIA. In: CONGRESSO NACIONAL DO CONPEDI, 17. 2008, Brasília. Anais [...]. Brasília:CONPEDI,2008.p.1429-1458.Disponívelem: http://www.publicadireito.com.br/conpedi/manaus/arquivos/anais/brasilia/02_897.pdf. Acesso em: 23 jun. 2020.

[2] ALVES, A. W. (2007). A Ineficácia da Legislação no Combate à Biopirataria na Amazônia.XVICongresso Nacional do CONPEDI, 2007, Belo Horizonte. Anais.(FundaçãoBoiteux),3750.Disponívelem:http://www.publicadireito.com.br/conpedi/manaus/arquivos/anais/bh/anna_walleria_guerra_alve s.pdf. Acesso em: 22 maio 2020.

[3] DENER GIOVANINI. RENCTAS (org.). 1o Relatório Nacional sobre o Tráfico de Animais Silvestres.Brasília:RENCTAS,2001.108p. Disponível em: http://www.renctas.org.br/trafico-de-animais/. Acesso em: 22 maio 2020

[4] FERNANDES, David Augusto et al. SOBERANIA PERMANENTE E A PROTEÇÃO AMBIENTAL. Rev. Fac. Direito UFMG, Belo Horizonte, v. 70, n. 22, p. 227-248, 9 jan. 2017. Disponível em: https://web.direito.ufmg.br/revista/index.php/revista/article/view/1847. Acesso em: 1 dez. 2020

[5] GALDINo, Valéria Silva. DAS PLANTAS MEDICINAIS E A BIOPIRATARIA. Disponível em:http://www.publicadireito.com.br/conpedi/manaus/arquivos/anais/manaus/direito_ambiental_valeria_silva_gal dino.pdf. Acesso em: 23 jun. 2020.

[6] GOMES, Magno Federici; SAMPAIO, José Adércio Leite. BIOPIRATARIA E CONHECIMENTOS TRADICIONAIS: as faces do biocolonialismo e sua regulação. Veredas do Direito: Direito Ambiental e Desenvolvimento Sustentável, [S.L.], v. 16, n. 34, p. 91-121, 31 maio 2019. Editora Dom Helder. http://dx.doi.org/10.18623/rvd.v16i34.1274.

[7] GOMES, R. Controle e a Repreensão da Biopirataria no Brasil, 2007. Disponível em: https://bd.tjmg.jus.br/jspui/bitstream/tjmg/555/1/D3v1832007.pdf. Acesso em: 22/05/2020

[8] HOMMA, Alfredo Kingo Oyama. BIOPIRATARIA NA AMAZÔNIA: como reduzir os riscos? Amazônia: CIÊNCIA \& DESENVOLVIMENTO, Belém, v. 1, p. 47-60, jul./dez. 2005.

[9] IZIQUE, Claudia. Ações contra a biopirataria: ompi estuda medidas para proteger culturas e recursos genéticos. Pesquisa FAPESP, São Paulo, n. 76, p. 14-17, jun. 2002. Disponível em: https://revistapesquisa.fapesp.br/folheie-a-ed-76/. Acesso em: 24 jun. 2020

[10] LIMA, Luan Lucas Cardoso et al. Características gerais dos anfíbios anuros e sua biodiversidade. Diversitas Journal, Santana do Ipanema, v. 4, n. 15, p. 774-789, out.

2019.Disponívelem:https://periodicos.ifal.edu.br/diversitas_journal/article/view/844/862. Acesso em: 2 dez. 2020.

[11] MEDINA, Luis Felipe Avelino; ALMEIDA, Maria Suely Cruz de. BIOPIRATARIA: A EXPLORAÇÃO DA BIODIVERSIDADE NO ESTADO DO AMAZONAS E A NECESSIDADE DE REGULAMENTAÇ̃̃O. Disponível em: http://publicadireito.com.br/conpedi/manaus/arquivos/anais/manaus/propried_intelectual_luis_medina_e_maria_d 
e_almeida.pdf. Acesso em: 23 jun. 2020.

[12] OLIVEIRA, Natiela Beatriz de; PIRES JÚNIOR, Osmindo Rodrigues. Venenos e peçonhas animais: aplicações tecnológicas e biopirataria. aplicações tecnológicas e biopirataria. Disponível em: http://www.cpgls.pucgoias.edu.br/6mostra/artigos/SAUDE/NATIELA\%20BEATRIZ\%20DE\%200LIVEIRA\%20E\%20 OSMINDO\%20RODRIGUES\%20PIRES\%20J\%C3\%9ANIOR.PDF. Acesso em: 24 jun. 2020

[13] PANCHERI, I. Biopirataria: Reflexões sobre o tipo penal. Revista da faculdade de direito, Universidade de São Paulo. v.108, p.448 - 478, 2013. Disponível em: https://www.revistas.usp.br/rfdusp/article/view/67993. Acesso em $22 / 05 / 2020$

[14] POZZETTI, Valmir César; MENDES, Máryka Lucy da Silva. Biopirataria na Amazônia e a ausência de proteção jurídica. Revista Direito Ambiental e Sociedade, Caxias do Sul, v. 4, p. 209-234, dez. 2014.

[15] QUEROZ, Danilo et al (org.). Biopirataria. Consciência: revista de divulgação cientifica, Taguatinga, v. 6, p. 34, ago. 2020. Disponível em: https://observatorio.sescdf.com.br/noticias/SiteAssets/Paginas/Sala-deCi\%C3\%AAncias-do-Sesc-DF-lan\%C3\%A7a-sexta-edi\%C3\%A7\%C3\%A3o-de-revista-com-o-temabiopirataria/Consciencia\%20\%286\%29.pdf. Acesso em: 02 dez. 2020.

[16] ROSA, Júlio Cardoso et al. OS ASPECTOS ETNOBOTANICOS DA COPAÍBA. Revista Geografar: Revista Eletrônica do Programa de Pós-graduação em Geografia -UFPR, Curitiba, v.4, p. 59-77, jan. 2009. Disponível em: https://revistas.ufpr.br/geografar/article/view/14428/9696. Acesso em: 02 dez. 2020.

[17] VALÉRIO, Cristine Quebin et al. A BIOPIRATARIA: problemas da mordenidade. In: CONGRESSO INTERNACIONAL DE TECNOLOGIAS PARA O MEIO AMBIENTE - FIEMA, 2, 2010, Bento Gonçalves. Anais [...]. Bento Gonçalves: $\quad$ Fiema, $2010 . \quad$ p. $\quad 1-15 . \quad$ Disponível em:https://siambiental.ucs.br/congresso/getArtigo.php?id=37\&ano=_segundo. Acesso em: 22 maio 2020.

[18] VARGAS, Xangai Gustavo et al. Produtos Brasileiro patenteados por estrangeiros: biopirataria - um estudo bibliografia. Intesa - Informativo Técnico do Semiárido, Pombal, v. 9, p. 30-36, jun. 2015. Disponível em: https://editoraverde.org/gvaa.com.br/revista/index.php/INTESA/article/view/3999. Acesso em: 02 dez. 2020.YANAI, Angela Emi et al. PATENTEAMENTO NA AMAZÔNIA: ANÁLISE BIBLIOMÉTRICA DO CUPUAÇU (THEOBROMA GRANDIFLORUM). In: XI ENCONTRO NACIONAL DE PESQUISA EM CIêNCIA DA INFORMAÇ̃̃̂O INOVAÇÃO E INCLUSÃO SOCIAL: QUESTÕES CONTEMPORÂNEAS DA INFORMAÇÃO, 9, 2010, Rio de Janeiro. Anais

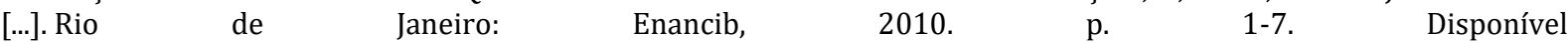
em:http://repositorios.questoesemrede.uff.br/repositorios/bitstream/handle/123456789/1922/Patenteamento\%2 0-\%20Yanai.pdf?sequence=1. Acesso em: 1 dez. 2020. 


\section{Capítulo 6}

\section{A proteção dos animais no ordenamento Jurídico brasileiro}

\section{Graciela Flávia Hack \\ Ozana Rodrigues Boritza \\ Camila Ferreira Ribeiro}

Resumo: A presente pesquisa tem por objetivo realizar uma análise sobre a proteção constitucional e legal conferida aos animais pelo ordenamento jurídico brasileiro. Por meio de revisão bibliográfica foi possível averiguar que a legislação infraconstitucional confere tratamento diverso dependendo da classificação empregada: doméstico ou silvestre. Constatou-se, ainda, a importância do papel desempenhado pelo Supremo Tribunal Federal, que, em diversos julgamentos, declarou a inconstitucionalidades de leis que permitiam direta e indiretamente a submissão de animais a tratamento cruel, em desacordo com o artigo 225, §1ํㅡㄴ, VII, da Constituição Federal de 1988.

Palavras-chave: Proteção; Direito dos Animais; Supremo Tribunal Federal. 


\section{INTRODUÇ̃̃O}

O desenvolvimento do senso de justiça pelos direitos dos animais, aos poucos, vem logrando êxito na elaboração de normas protetivas, isto porque a luta contra maus- tratos e crueldade contra animais é recente, pois somente após a segunda metade do século XX, que a causa ecológica ganhou maior engajamento (LEVAI, 1998).

Como reflexo desta participação ativa em prol do bem ecológico, a Constituição Federal de 1988 (CRFB/1988), de forma inovadora, elevou a tutela ambiental ao patamar constitucional. E, ainda, trouxe em seu art. $225, \S 1^{\circ}$, inciso VII, a expressa vedação quanto às práticas que submetam os animais à crueldade.

Esta matéria é regulada por intermédio de uma gama de leis esparsas, e algumas delas em dado momento conflitam com o texto constitucional. Assim, mostra-se essencial o estudo conjunto da jurisprudência do tema.

Desta forma, o presente trabalho tem como objetivo analisar o tratamento protetivo conferido aos animais no ordenamento jurídico brasileiro, incluindo as decisões proferidas pelo Supremo Tribunal Federal nesta temática.

\section{METODOLOGIA}

A metodologia de pesquisa adotada para a realização do presente trabalho baseia-se na revisão bibliográfica, com caráter exploratório, tendo em vista a busca por informações quanto ao tratamento protetivo legal conferido aos animais, por meio da análise de doutrina e artigos científicos especializados sobre o tema em comento.

\section{RESULTADOS E DISCUSSÃO}

A tutela constitucional protetiva dos animais vem estampada no artigo 225 , §1ํㅡㄴ, VII, da CRFB/1988, mas os mais diversos textos legais tangenciam o assunto, inclusive leis anteriores e à atual Constituição Federal, trazendo tratamento diferenciado entre eles.

À luz do Código Civil de 2002 (CC/02), os animais são considerados como propriedade, natureza jurídica que viabiliza maiores abusos contra os animais. Os animais domésticos são tutelados pela Lei de Crimes Ambientais (Lei no 9.605/98), enquanto os animais silvestres possuem proteção na Lei de Proteção à Fauna (Lei no $5.197 / 67$ ).

Porém, em setembro de 2020, houve alteração da Lei no 9.605/98 pela Lei no 14.064/2020, aumentando a pena de maus-tratos, com pena de reclusão, de dois a cinco anos, multa e proibição de guarda, exclusivamente quando se tratar de cães e gatos.

No entanto, em razão do tratamento constitucional que lhe é conferido, mostram- se possíveis análises acerca da constitucionalidade de normas infraconstitucionais que versam sobre matéria ambiental ou que de alguma forma, influam neste âmbito ou na esfera protetiva dos animais não humanos.

Neste sentido, manifesta-se a competência do Supremo Tribunal Federal (STF), que apresenta importantes decisões, em controle de constitucionalidade quanto ao status jurídico dos direitos dos animais previsto em normas infraconstitucionais, levando-se em consideração o fato de que as decisões judiciais desempenham um papel na orientação de práticas cotidianas concernentes aos seres humanos e aos animais.

A luta pelos direitos e dignidade dos animais faz-se imprescindível, pois a ética animal fortalece o combate de práticas abusivas aos seres-humanos. 0 protecionismo animal não discrimina e não exclui. (ANDRADE, 2016)

Assim, passa-se a analisar as principais decisões do STF. Inicialmente, tem-se a Ação Direta de Inconstitucionalidade (ADI) no 1856/RJ, cujo objeto era a declaração da inconstitucionalidade da Lei no 2.895/1998, do Estado do Rio de Janeiro, que permitia a prática da rinha de galo, em que estes animais combatiam até a morte em cruéis condições (LIMA, 2009; ESCOBAR, 2014).

A Suprema Corte sopesou, neste julgamento, dois valores constitucionais, quais sejam o direito à cultura e a vedação à crueldade animal, restando, ao final, a inconstitucionalidade da lei fluminense. 
O julgamento do Recurso Extraordinário no 153.531-8, também configura uma importante decisão para a causa animal. Nesta oportunidade, o STF analisou a constitucionalidade da expressão cultural denominada Farra do Boi, em que uma multidão agride o animal quebrando-lhe os chifres, perfurando os seus olhos, além da quebradura de ossos, para só então ser abatido (DIAS, 2000; LEVAI, 2006).

E novamente, seguindo a mesma ponderação anterior, houve a declaração de inconstitucionalidade pautada na vedação à crueldade aos animais.

Em 2016, na ADI no 4983, que versou sobre a compatibilidade constitucional da lei cearense no 15.299/2013, responsável pela regulamentação da tradição da vaquejada, que consiste no emparelhamento do animal por dois vaqueiros, que segurando seu rabo, buscando derrubá-lo no chão, provocando severas lesões nos animais utilizados (GORDILHO \& FIGUEIREDO, 2016; DIAS, 2000; LEVAI, 2006).

Restou a decisão final do STF, por seis votos a cinco, por considerar inconstitucional a prática da vaquejada, haja vista sua violação de princípios constitucionais do meio ambiente.

Ressalta-se que esta decisão protetiva ambiental refletiu em questões econômicas, já que a vaquejada movimenta grandes quantias, bem como a promoção de empregos nas regiões em que é praticada. Assim, houve uma reação legislativa do Congresso Nacional, advinda de efeito denominado blacklash, contramovimento que busca resgatar preceitos conservadores diante de uma mudança de paradigma em tradições enraizadas da sociedade, culminando na Emenda Constitucional no 96/2017, que elevou a vaquejada ao status de expressão de manifestação cultural.

O STF julgou o Recurso Extraordinário n.494.601 acerca do uso de animais em cultos de religiões de matrizes africanas, litígio entre dois direitos constitucionais, ao exercício da liberdade religiosa e à proteção ao meio ambiente ecologicamente equilibrado. Fundando-se na intolerância religiosa existente contra as religiões de matrizes africanas, a Suprema Corte julgou ser constitucional o abate de animais em cultos de matrizes africanas, motivada pelo fato de ser esta a religião mais condenada pela sociedade que desconhece a estrutura destes credos.

\section{CONSIDERAÇÕES FINAIS}

Por todo o exposto, pode-se concluir que os direitos dos animais alcançaram o patamar máximo dentro do ordenamento jurídico brasileiro, isto é, com a CRFB/88 houve a sua constitucionalização, logo se apresentando como parâmetro na análise de constitucionalidade das normas infraconstitucionais.

Observa-se que os julgados referentes aos animais vêm sendo por considerar o panorama biocêntrico que assegura a salvaguarda de todas as espécies como partes importantes para um meio ambiente ecologicamente equilibrado. Por este motivo, importante se dá a atuação jurisprudencial na luta contra práticas abusivas aos animais.

\section{REFERÊNCIAS}

[1] AGUIAR, José Otávio; ESCOBAR, Marco Lunardi. Aspectos histórico-legais das rinhas de galo na paraíba: uma prática cultural e problema socioambiental. Revista Memória em rede, 2014, n. 10, p. 2, 2014.

[2] ANDRADE, Fernanda. ZAMBAM Neuro José. A condição de sujeito de direitos dos animais humanos e nãohumanos e o critério da senciência. Revista Brasileira de Direito Animal, Bahia, v. 11, n. 23, p. 143-171, 2016.

[3] BRASIL. Constituição. Brasília: Senado Federal, 1988

[4] BRASIL. Lei n. 10.406, de 10 de janeiro de 2002. Institui o Código Civil. Disponível em: http://www.planalto.gov.br/ccivil_03/leis/2002/l10406.htm. Acesso em: 04 mar. 2020.

[5] BRASIL. Supremo Tribunal Federal. ADI n. 1856. Relator Ministro Celso de Mello. DJ:26/05/2011. STF, 2011.Disponível em: < http://redir.stf.jus.br/paginadorpub/paginador.jsp?docTP=AC\&docID=628634>. Acesso em 23 nov. 2019.

[6] BRASIL. Supremo Tribunal Federal. ADI n. 4983. Relator: Ministro Marco Aurélio. DJ: 06/10/2016. Disponível em <http://redir.stf.jus.br/paginador.pub/paginador.jsp?docTP=TP\&docID=12798874> Acesso em 11 mar. 2020.

[7] BRASIL. Supremo Tribunal Federal. Recurso Extraordinário 153.531 -8. Relator Ministro Marco Aurélio. DJ: 13/03/99. Disponível em <http://redir.stf.jus.br/paginadorpub/paginador.jsp?docTP=AC\&docID=211500> Acesso em 10 mar. 2020. 
[8] BRASIL. Supremo Tribunal Federal. Recurso Extraordinário n. 494.601. Relator Ministro Marco Aurélio. DJ: 28/03/2019. Disponível em:<http://redir.stf.jus.br/paginadorpub/paginador.jsp?docTP=TP\&docID=751390246> Acesso em: 30 mar. 2020.

[9] DECLARAÇÃO de Cambridge Sobre a Consciência em Animais Humanos e Não Humanos. Universidade de Cambridge, 7 de julho de 2012. Disponível em:< http://www.ihu.unisinos.br/172- noticias/noticias-2012/511936declaracao-de-cambridge-sobre-a-consciencia-em-animais- humanos-e-nao-humanos>. Acesso em: 30 mar. 2020.

[10] DIAS, Edna Cardozo. A tutela jurídica dos animais. Belo Horizonte: Mandamentos, 2000, p.80- 81.

[11] GORDILHO, Heron Jose de Santana; FIGUEIREDO, Francisco José Garcia. A Vaquejada à Luz da Constituição Federal. Revista de Biodireito e Direito dos Animais. Curitiba, Volume 2, Número 2, 2016, p. 79.

[12] LEVAI, Laerte Fernando. Direito dos animais: o direito deles e o nosso direito sobre eles. Campos do Jordão, SP: Mantiqueira, 1998. p. 20.

[13] LEVAI, Laerte Fernando. Crueldade Consentida - Critica à razão antropocêntrica -. Revista Brasileira de Direito Animal. Salvador, volume I, 2006.

[14] LIMA, Racil. Direito dos Animais: Aspectos Históricos, Éticos e Jurídicos. Brasília: Associação Nacional dos Analistas do Poder Judiciário e do Ministério Público da União, 2009. 


\section{Capítulo 7}

\section{Agroecologia em prosa virtual: Uma extensão universitária possível no contexto de pandemia}

\section{Maria Luiza Andrade de Farias Aires \\ Gabrielle Custódio Melo \\ Luciano Majolo \\ Shirleyde Alves dos Santos}

Resumo: O Núcleo de Extensão Rural Agroecológica (NERA) da Universidade Estadual da Paraíba reúne diversos projetos de extensão do Campus II da UEPB, sendo uma de suas principais atividades durante a pandemia da covid-19 a promoção de prosas virtuais sobre saúde, educação e agroecologia na chamada "Agroecologia em Prosa Virtual". Os temas são discutidos em uma sala virtual privada através da conta institucional do NERA/UEPB na plataforma Google Meet, onde as conversas podem ser gravadas para serem disponibilizadas posteriormente. 0 público integrante das prosas é bastante variado, uma vez que elas são abertas a quem manifestar interesse em participar, mas é composta em sua maioria por agricultores e agricultoras, professores/as, pesquisadores/as e estudantes de várias regiões do país. Nesse contexto de distanciamento social, o projeto oferece interação com pessoas residentes em diferentes lugares do Brasil e do mundo de forma online, ampliando a possibilidade de contatos com especialistas nos assuntos propostos nas prosas. Esta plataforma aumenta o alcance dos debates sobre saúde humana e ambiental, educação e agroecologia. Assim, a proposta da Agroecologia em Prosa Virtual surge como um meio para difusão e fortalecimento da agroecologia, e dos diálogos entre agroecologia e saúde, tendo a internet como uma aliada para ajudar a manter, renovar e formar novas redes de apoio entre professores/as, alunos/as, agricultores/as, técnicos/as, entusiastas e consumidores/as de alimentos provenientes da agricultura familiar. 


\section{INTRODUÇ̃̃OO}

Após a paralisação das atividades presenciais devido à pandemia da covid-19, os projetos e as atividades desenvolvidas pelo programa de extensão "Agroecologia, Saúde e Cidadania: ações do Núcleo de Extensão Rural Agroecológica (NERA) pelo bem viver" passaram a ocorrer através das plataformas digitais (FIGURA 1).

Figura 1. Card de divulgação da Agroecologia em Prosa, promovida pelo programa de extensão "Agroecologia, saúde e cidadania: Ações do Núcleo de Extensão Rural Agroecológica (NERA) pelo bem viver" da Universidade Estadual da Paraíba (UEPB).

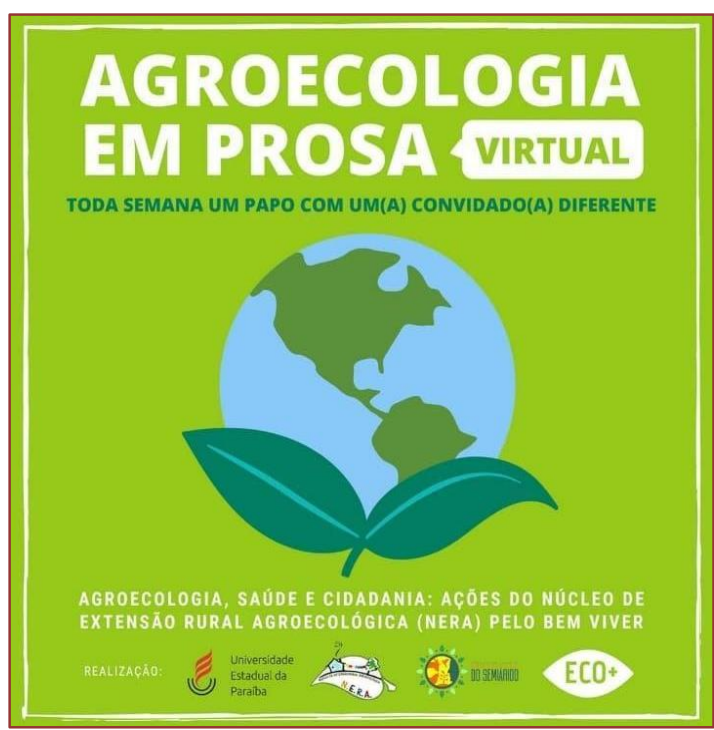

(Fonte: www.instagram.com/nera.uepb)

A atividade "Agroecologia em Prosa" já acontecia presencialmente, mas limitava-se a convidadas/os da região local ou próximas ao Campus II da UEPB, em Lagoa Seca, na Paraíba. Partindo do princípio de que a agroecologia é fomentada pelas trocas e diálogos de saberes, o modelo adotado para as prosas possibilita que não somente o/a convidado/a experiente no assunto debata, mas também as pessoas interessadas no tema abordado. A prosa virtual oportuniza que diversas pessoas de todo o território brasileiro participem dos debates, o que aumenta o círculo de troca de conhecimento entre os/as envolvidos/as, algo que não aconteceria no modelo presencial devido às distâncias geográficas. É possível perceber essa abrangência da Agroecologia em Prosa Virtual analisando os estados onde os/as convidados/as e participantes se situam, como Paraná, Rio Grande do Norte, Rio de Janeiro, Minas Gerais, entre outros estados (FIGURA 2).

Figura 2. Mapeamento das localidades de onde o público participante das prosas vivem.

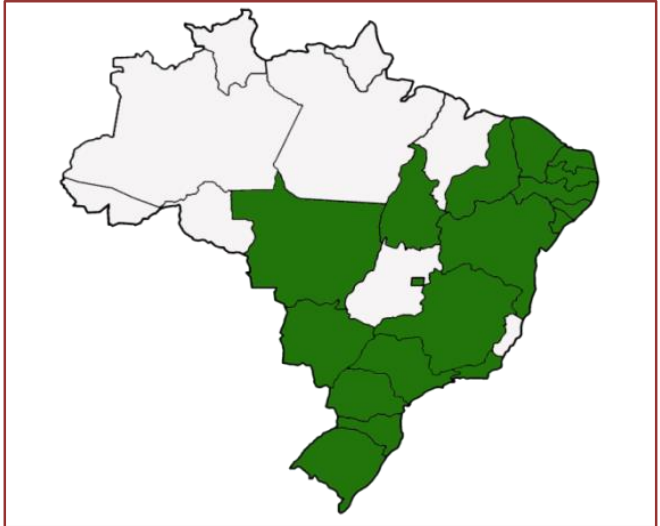

(Fonte: imagem da autoria própria). 
Os cards com informações sobre as prosas (tema, convidados/as, dias e horários) são compartilhados e divulgados através das redes sociais do NERA, no Instagram e Whatsapp. Os/as interessados/as podem acessar a sala através de um link que é disponibilizado no card e cada prosa tem por volta de duas horas de duração, podendo os/as participantes solicitarem um certificado de participação ao final do evento, através de e-mail.

Objetiva-se com este trabalho relatar as atividades desenvolvidas pelo Programa de Extensão em tempos de pandemia, seus alcances e suas conquistas, ressaltando a importância da dialogicidade na construção dos saberes sobre saúde humana e ambiental, educação e sobre os ensinamentos profundos que o contato com a agroecologia proporciona.

\section{METODOLOGIA}

As ações educativas do NERA são realizadas através de metodologias participativas, fundamentadas na pedagogia dialógica de Paulo Freire que prioriza o diálogo de saberes, através do encontro de sujeitos interlocutores que buscam conjuntamente a significação dos significados (FREIRE, 1983).

Em vista disso, a atividade Agroecologia em Prosa Virtual é fundamentada na horizontalidade de expressão e comunicação entre o público e as pessoas convidadas a conduzirem os debates, uma vez que os saberes empíricos, experienciados em vivências pessoais ou coletivas, não são menos importante do que os saberes técnicos e academicistas, mas são saberes que se constroem e se aperfeiçoam juntos, através do diálogo.

Segundo FREIRE (1983, p. 15) "educar e educar-se, na prática da liberdade, é tarefa daqueles que sabem que pouco sabem - por isso sabem que sabem algo e podem assim chegar a saber mais - em diálogo com aqueles que, quase sempre, pensam que nada sabem, para que estes, transformando seu pensar que nada sabem em saber que pouco sabem, possam igualmente saber mais".

É exatamente neste sentido de diálogo dos saberes que a Agroecologia em Prosa Virtual é expandida para além dos muros da academia e da relação docente-discente, possibilitando que a comunicação seja nivelada entre todas as pessoas que compõem juntas essas trocas.

\section{RESULTADOS E DISCUSSÃO}

O projeto da Agroecologia em Prosa Virtual já viabilizou vinte e duas (22) prosas sobre diferentes temas dentro do eixo saúde humana/ambiental, educação e agroecologia, mediadas pelas professoras Shirleyde Santos, Élida Corrêa e Rita de Cássia e pelo professor Leandro de Oliveira Andrade, do curso de bacharelado em agroecologia da UEPB.

A programação teve início no dia 4 de junho de 2020 com a participação da primeira convidada, Fernanda Savicki, agrônoma e pesquisadora em Saúde Pública na Fundação Oswaldo Cruz (Fiocruz-MS) e vicepresidenta da Associação Brasileira de Agroecologia (ABA), há 20 anos trabalhando com agricultura familiar e agroecologia. Além de promover um debate muito relevante sobre a importância da soberania alimentar e nutricional, Fernanda trouxe também reflexões significativas sobre a perda da biodiversidade dentro de um sistema convencional de produção de alimentos. A convidada trouxe a máxima de que "comidas são commodities, come quem tem dinheiro", apontando que a questão da fome no mundo não é devida a uma suposta "falta de disponibilidade de alimentos", mas ocasionada pela má distribuição dos mesmos, e pelo modelo produtivo vigente em nosso país.

Já na segunda prosa promovida pelo projeto, que aconteceu no dia 10 de junho de 2020, contamos com contribuições das convidadas Fernanda Maria Coutinho de Andrade, agrônoma e professora doutora na Universidade Federal de Viçosa, e a agrônoma e professora doutora da Universidade Estadual da Paraíba, Élida Barbosa Corrêa. Ambas partilharam estudos e técnicas sobre a homeopatia na agroecologia e sobre o controle biológico de doenças de plantas, ressaltando o valor da homeopatia como prática de independência dos agricultores e como pilar da agricultura orgânica.

No terceiro encontro da Agroecologia em Prosa, que ocorreu no dia 11 de junho de 2020, tivemos a presença brilhante da Valdirene Militão, que trabalha na Fiocruz Mata Atlântica e é moradora da comunidade da Maré, no Rio de Janeiro. Ela trouxe falas muito importantes sobre a produção alternativa de alimentos por meio da agricultura urbana e nos relatou que, no contexto de pandemia, além de produzir uma diversidade de alimentos e ervas na laje de sua própria casa, também tem produzido máscaras de pano para doar às pessoas em situação de vulnerabilidade social na área em que reside. 
No quarto encontro da Agroecologia em Prosa, ocorrido no dia 18 de junho de 2020, contamos com a presença do André Burigo, sanitarista da Fiocruz e membro do GT-Saúde da Associação Brasileira de Agroecologia (ABA). André fez observações pertinentes sobre a importância da articulação entre profissionais da saúde e da agroecologia, principalmente no âmbito do SUS, para atuação na saúde e bem estar geral da sociedade. 0 convidado evidenciou o impacto nocivo dos agrotóxicos, aproximando os temas da agroecologia e da saúde pública. Também foi enfatizado que a busca por alimentos saudáveis passa por sistemas agroecológicos de produção e que a agroecologia atinge não somente uma, mas todas as metas do Objetivo de Desenvolvimento Sustentável (ODS). Ressaltou que, ao contrário, a agricultura convencional com o uso intensivo de agrotóxicos e sementes transgênicas para a produção de commodities gera diversos impactos negativos sobre o meio ambiente, a economia, a saúde e a sociedade. A prosa foi finalizada reforçando a importância de um alimento saudável, tanto no sentido social e ambiental, quanto econômico, compondo uma alimentação que colabora para a saúde planetária.

A quinta prosa, no dia 26 de junho de 2020, contou com a presença da engenheira agrônoma, fundadora do projeto Caminhos da Roça (rede de delivery de alimentos orgânicos em São Paulo/SP), Marina Pascon, e com a nutricionista e membra do GT-Saúde da ABA, Adriana Adell. Foi discutida a fome como uma questão política, expondo questões como a produção e a oferta dos alimentos, principalmente o acesso a alimentos orgânicos e agroecológicos para pessoas que vivem à margem da sociedade. Também foi ressaltada a importância da oportunidade de escolha pelos indivíduos sobre a sua alimentação e de como isso os torna agentes de mudança do sistema produtivo. Identificou-se os impactos positivos dos circuitos curtos de produção e consumo dos alimentos, introduzindo a participação da sociedade na transição agroecológica e evidenciando a Agroecologia como promotora de Saúde, Soberania e Segurança Alimentar.

A sexta prosa, que aconteceu no dia 01 de julho de 2020, contou com a participação da Maria Amália da Silva Marques, agrônoma e mestre em Extensão Rural e Desenvolvimento Local, assessora técnica em Sistema de Produção Agroecológica e Orgânica, agricultora e sócia do Sistema Participativo de Garantia Rede Borborema de Agroecologia. Amália explicou de forma bastante acessível a legislação e os mecanismos de certificação de orgânicos no Brasil, enfatizando os Sistemas Participativos de Garantia (SPG) como instrumentos fundamentais para a transição agroecológica, por darem acesso à certificação aos agricultores familiares.

Na sétima prosa, ocorrida no dia 02 de julho de 2020, contamos com as contribuições da epidemiologista do Instituto Nacional do Câncer (INCA) e membra do GT-Saúde da ABA, Fernanda Nogueira. Fernanda trouxe dados muito impactantes que mostram a correlação entre casos de câncer e a exposição aos agrotóxicos (por via oral, por inalação, por ingestão ou por contato com a pele), deixando claro que a produção convencional de alimentos feita pelo agronegócio não prejudica somente as esferas ambientais (contaminando solo, água, ar, fauna e flora), como também é um grande risco à saúde humana.

Na oitava edição da Agroecologia em Prosa tivemos uma conversa muito interessante e edificante sobre a presença de agrotóxicos na água e sobre seu perfil de potabilidade. 0 debate teve a participação do Claudiomir Silva Santos, professor doutor e pesquisador do Instituto Federal Sul de Minas, Campus Muzambinho, e contamos também com a participação do enfermeiro, biólogo, mestre em Plantas Medicinais e Doutor em Promoção da Saúde, Fabrício Santos Ritá, que atualmente também é docente e coordenador do Curso Técnico em Vigilância em Saúde do Instituto Federal Sul de Minas, Campus Muzambinho. Os convidados expuseram dados que alertam sobre a quantidade de agroquímicos encontrados na água potável de diversas cidades brasileiras, especialmente naquelas localizadas próximas à grandes cultivos. Também ressaltaram que não há dose segura para sua aplicação e que sua utilização tem efeito acumulativo no meio ambiente e no organismo dos seres vivos, evidenciando assim a importância da comunicação com os agricultores e agricultoras sobre a realidade nociva do uso de agrotóxicos.

A nona edição do projeto teve como tema a psicoterapia em tempos de covid-19 e contou com a participação das psicólogas Andreza Santos e Maria Luiza Medeiros, dessa vez com mediação feita pelo engenheiro agrônomo e professor doutor Leandro Oliveira de Andrade, docente do curso de Bacharelado em Agroecologia, graduando no curso de Psicologia pela Universidade Federal de Campina Grande (UFCG) e pós-graduando em Saúde Mental. Essa prosa, em especial, não foi gravada, para que o público participante se sentisse mais à vontade para partilhar questionamentos e desabafos sobre como o isolamento social tem afetado psicologicamente e emocionalmente cada pessoa que marcou presença nesse encontro virtual.

A décima edição teve como tema "a agroecologia em ambientes sujeitos à estiagem" e contou com a presença de Leonardo Tinoco, que é engenheiro agrônomo, doutor em Ciência do Solo, pesquisador e 
membro do projeto ZIKA/UEPB e que atualmente trabalha no desenvolvimento de projetos de aquaponia integrados a sistemas agroecológicos em ambientes com restrições hídricas. Ele trouxe falas sobre a importância de proteger o solo do semiárido do empobrecimento causado por processos de lixiviação e pelos problemas gerados pela irradiação solar. Tinoco também enfatizou a seca como uma adversidade agravada pela má gestão dos governantes e não somente pela estiagem, frisando a importância da soberania hídrica assegurada através de cisternas e meios de reservas da água da chuva. Foi ressaltada a importância da utilização correta da água a fim de garantir a sustentabilidade dos sistemas de produção de alimentos. Os participantes ainda discutiram sobre a utilização de peixes em reservatórios de água como controladores biológicos, reduzindo a incidência do Aedes aegypti, transmissor das arboviroses dengue, zika e chikungunya.

Na décima primeira prosa, ocorrida no dia 30 de julho de 2020, contamos com a participação de Rodrigo Machado e Beatriz Stamato, no diálogo intitulado "Bases teóricas e metodológicas da agroecologia". 0 Rodrigo Machado é doutor em Agroecologia, Sociologia e Desenvolvimento Rural Sustentável, pela Universidade Córdoba na Espanha. A Beatriz Stamato, atualmente é professora na Faculdade Galileu e pesquisadora e membro do conselho gestor do INTERSSAN/UNESP - Botucatu. Ambos foram fundadores do Núcleo de Extensão Rural Agroecológica (NERA), da UEPB. Inicialmente, foi defendida a importância da ciência e problematizado a forma como hoje ela é produzida, racionalizada e positivista, o que acarreta em uma centralização do saber e desvalorização do conhecimento popular. Ao longo do diálogo a agroecologia foi posta como uma ciência co-evolucionista, que une as ciências naturais e sociais, descentralizando assim o conhecimento. Também, os sistemas agroecológicos foram enfatizados como vanguardistas de um desenvolvimento rural sustentável e equitativo.

A prosa seguinte, aconteceu no dia 5 de agosto de 2020, contou com a participação da Naiara Bitterncourt, advogada popular na Terra de Direitos, integrante do GT Biodiversidade da Articulação Nacional de Agroecologia (ANA) e da Campanha Permanente Contra os Agrotóxicos e Pela Vida; o Leonardo Melgarejo, doutor em Engenharia de Produção, membro da ABA Agroecologia, do fórum gaúcho Contra os Impactos dos Agrotóxicos e do Movimento Ciência Cidadã; e de Euzébio Cavalcanti, agricultor, poeta, presidente do Sindicato dos Trabalhadores e Trabalhadoras Rurais de Remígio/PB, faz parte da Coordenação da Rede de Bancos Comunitários de Sementes do Polo da Borborema. A roda de conversa teve como tema "Agrotóxicos e transgênicos x Comida de Verdade" e foi transmitida em uma live pelo canal da UEPB, no Youtube. A prosa trouxe diversas informações importantes sobre os impactos gerados à saúde e ao meio ambiente pelo uso de agrotóxicos e transgênicos. Por fim, foi enfatizado a importância da valorização das sementes crioulas na construção de uma alimentação acessível, justa e sustentável. Essa atividade foi uma articulação NERA/CVT/UEPB, a ASA PB, o CONSEA PB, a Campanha Permanente Contra os Agrotóxicos e Pela Vida PB, e o Forum Paraibano de Segurança e Soberania Alimentar e Nutricional.

A décima terceira prosa, realizada no dia 07 de Agosto de 2020, contou com a participação de Cristiane Coradin, Lorena Portela Soares, Claudemar Santos e Shirleyde Santos. Diferentemente das outras conversas, essa teve como finalidade orientar as organizações, movimentos populares e grupos de pesquisa, para realização do cadastramento das práticas e experiências em saúde e agroecologia, desenvolvidas nos seus territórios, na plataforma "Agroecologia em Rede". 0 Agroecologia em Rede, tem como uma de suas finalidades realizar o mapeamento das experiências agroecológicas , a fim de fortalecer os movimentos e amplificar a agroecologia para o Brasil e América Latina

No décimo quarto encontro, feito no dia 20 de agosto de 2020, contamos com a participação do André Ferreira, Mestre em Filosofia e Doutor em Filosofia da Educação pela UFPE; do Euriko Santos Yogi, Engenheiro Agronômo, Mestre em Agroecologia e Desenvolvimento Rural pela UFSCar, e doutorando em Extensão Rural pela UFSM; e da Albertina Maria Ribeiro Brito de Araújo, graduada em Administração, Mestra em Educação e Políticas Públicas e Doutora em Educação Popular. A mediação foi feita pela professora Rita de Cássia Cavalcante, graduada em Pedagogia e Mestra em Educação. A conversa foi guiada pelo tema "Educar para a agroecologia segundo a perspectiva de Freire", onde foi debatida a importância de uma visão Freireana na construção da agroecologia e como base das extensões rurais. Dialogar Freire e Agroecologia foi e é tomar consciência do outro e do ser com o outro para transformação da realidade juntos, onde as relações sociais, culturais e ambientais são consideradas nesse fortalecimento das lutas.

Na prosa intitulada "PANC e suas possibilidades culinárias nutritivas", que aconteceu no dia 21 de agosto de 2020, contamos com as participações da Neuza Durães e Katiane Machado da Silva. A Neuza Durães é pós-graduada em Nutrição Clínica Funcional, possui capacitação em imersão culinária PANC e é pesquisadora em alimentação agroecológica sustentável com enfoque em PANC, flores comestíveis e nutrição evolutiva. A Katiane Machado é filha de assentados na Reforma Agrária, Militante Social e Pedagoga da terra. As convidadas expuseram sobre a importância das Plantas Alimentícias Não 
Convencionais (PANC), na garantia da soberania alimentar, sendo elas fontes acessíveis de nutrientes. Também foi abordado a importância das PANC como meio de resistência a um sistema alimentação tão monocultural. Ao longo da prosa, foi apresentada algumas PANC, suas utilizações e preparos culinários.

A décima sexta edição teve como tema "Um olhar psicanalítico sobre a racialidade e racismo" e contou com a presença de Nilton da Silva Nunes Junior, psicanalista e pesquisador. A prosa debateu assuntos importantes na luta anti-racista, estruturando um diálogo a partir da construção histórica da marginalização dos/as pretos/as, desde o período pré-abolicionista, até os dias atuais, o que reflete em danos físicos e mentais. A agroecologia não existe sem uma sociedade justa e igualitária, e a discussão sobre o racismo e outras formas de violência precisam estar presentes.

A décima sétima edição aconteceu com a participação da Wanessa Gomes, que apresentou um projeto de residência com ênfase em Agroecologia para formação multiprofissional para profissionais da área de saúde, em Pernambuco. Um projeto de extrema importância que traz a discussão da Agroecologia para os cursos da área de saúde. A saúde e a agroecologia não se dissociam e esta discussão precisa estar presente na formação de profissionais da área de saúde. . A residência iniciará no ano de 2021 e tem como público alvo: profissionais da atenção básica como dentistas, enfermeiros, médicos, farmacêuticos, entre outros.

Na décima oitava prosa, o médico Elver Moronte trouxe uma fala impactante sobre a relação entre agrotóxicos e saúde mental, além de relatar um episódio de intoxicação por agrotóxicos que ele mesmo teve, quando criança. No curso de medicina ele percebeu que tratar sobre agrotóxicos e sua relação direta com a saúde não era algo que fazia parte da realidade do curso, então só depois, já formado, que ele começou a se aprofundar no assunto. Relatou que no Paraná há grandes cultivos de fumo e que muitos dos agricultores estavam sendo diagnosticados com depressão, pensamentos suicidas, etc. e por isso ele começou a difundir o diálogo sobre os malefícios do uso de agrotóxicos para a saúde mental especialmente de quem trabalha com essas substâncias, destcando o trabalho desenvolvido pelo Observatório do Agrotóxico, uma parceria entre o Núcleo de Estudos em Saúde Coletiva - NESC, da Universidade Federal do Paraná, a Centro de Apoio Operacional das Promotorias de Justiça de Proteção ao Meio Ambiente do Ministério Público do Paraná e o Ministério Público do Trabalho no Paraná - PRT 9ạ Região.

A décima nona prosa aconteceu como uma conversa sobre assédio às mulheres nos ambientes familiares, de trabalho, e acadêmicos. Essa prosa não foi gravada, como de costume, uma vez que gravar poderia intimidar as participantes a interagirem sobre um tema tão delicado e difícil. As participantes relataram várias situações de abusos que viveram, enquanto o professor Leandro e a professora Shirleyde mediaram com comentários sobre construção histórica e social da mulher. Outro tema relevante e que não pode estar ausente das discussões sobre agroecologia.

A vigésima prosa, realizada no dia 11 de novembro de 2020, teve como tema "Plantas sagradas no curandeirismo popular" e contou com a participação do Oliveiros de Oliveira Freire, graduado em Agroecologia pela UEPB. O convidado trouxe levantamentos importantes que relacionam o uso de plantas no curandeirismo com suas propriedades medicinais e fisiológicas, além de espirituais. Ressaltando assim, a amplitude do conhecimento popular, da religiosidade, dos saberes tradicionais e da ciência.

A vigésima primeira prosa contou com a participação do Alan Tygel, engenheiro de computação e comunicador popular, membro da Campanha Permanente Contra os Agrotóxicos e Pela Vida. 0 convidado fez uma contextualização histórica do uso dos agrotóxicos no Brasil e de como surgiu a Campanha, trouxe também dados muito importantes sobre a utilização dos agrotóxicos no cultivos dos nossos alimentos, deixando claro que a agroecologia deve ser cada vez mais fortalecida e difundida como o modelo de produção capaz de alimentar toda a população de modo economicamente viável, ecologicamente correto, cultural e socialmente justo.

Por fim, a vigésima segunda prosa contou com a participação do Ricardo Lopes Machado, médico veterinário homeopata e extensionista rural da EMATER RS, que trouxe contribuições valiosas sobre a produção animal agroecológica, feita de forma respeitosa e humanizada, visando o bem-estar animal, sobre o Pastoreio Racional Voisin, e sobre suas experiências com homeopatia e fitoterapia animal em propriedades rurais.

A Agroecologia em Prosa Virtual é fundamentada na pedagogia dialógica de Paulo Freire, na qual o ato de ensinar e o ato de aprender não são independentes e bastantes em si, mas se constroem juntos, em uma troca potente de saberes. Saberes esses que acontecem tanto em esfera acadêmica, quanto nos demais ambientes, para além da universidade e resultantes de experiências coletivas e pessoais que todo ser humano vivencia. 
"No fundo, passa despercebido a nós que foi aprendendo socialmente que mulheres e homens, historicamente, descobriram que é possível ensinar. Se estivesse claro para nós que foi aprendendo que percebemos ser possível ensinar, teríamos entendido com facilidade a importância das experiências informais nas ruas, nas praças, no trabalho, nas salas de aulas das escolas, nos pátios dos recreios, em que variados gestos de alunos, de pessoal administrativo, de pessoal docente se cruzam cheios de significação." (FREIRE, 2019, p. 44)

Isto posto, fazer parte de projetos como o da Agroecologia em Prosa Virtual, especialmente nesse contexto de pandemia causada pelo covid-19 que nos obriga a viver um distanciamento social difícil e muitas vezes solitário, torna muito clara a importância das redes sociais e da internet como ferramentas de apaziguamento social. Os diálogos fortaleceram a importância da agroecologia não só como uma alternativa para produção saudável e sustentável de alimentos, mas como uma técnica de recuperação de áreas degradadas pelo agronegócio e pelo uso de agrotóxicos. Construíram-se diálogos e saberes muito importantes, que consolidam a agroecologia como promotora de segurança e soberania alimentar e nutricional no mundo e como resistência que resgata e preserva os saberes populares, respeitando os costumes culturais dos diferentes povos, mesmo em um mundo que atravessa graves crises sociais, políticas, culturais, ambientais e econômicas.

\section{CONSIDERAÇÕES FINAIS}

A partir do trabalho apresentado fica visível a importância das plataformas digitais, especialmente no presente contexto de distanciamento social, não só como um meio para manter a comunicação com nossos familiares e amigos, mas como um recurso significativo para a promoção de reflexões bastante válidas sobre os mais diversos temas, além da promoção e construção do conhecimento.

No caso específico da Agroecologia em Prosa, percebe-se que o engajamento do público participante nos debates conduzidos por convidados/as experientes, são como diferentes fios que tecem a teia tão importante de rede de apoio, necessária para a consolidação cada vez mais forte da agroecologia no Brasil. Percebe-se os vínculos construídos na luta por uma sociedade mais justa e igualitária, onde todos possam ter acesso à alimentos de qualidade e livres de agrotóxicos e transgênicos. São laços que se fortalecem ainda mais a cada debate e a cada troca que são experimentadas durante o projeto.

\section{REFERÊNCIAS}

[1] ALTIERI, Miguel A.; NICHOLLS, Clara Inés; DE INVESTIGACIONES AGROECOLÓGICAS, Centro Latinoamericano. La Agroecología en tiempos del COVID-19. (Tradução de Romier Sousa) University of California, Berkeley. Centro Latinoamericano de Investigaciones Agroecológicas CELIA, 2020, 1-6. (Disponível em: https://aba-agroecologia.org.br/a-agroecologia-em-tempos-de-covid-19/. Acesso em: 24 jun. 2020).

[2] FREIRE, Paulo. Pedagogia da Autonomia: saberes necessários à prática educativa. 62 ${ }^{\underline{a}}$ ed. Rio de Janeiro/São Paulo: Paz e Terra, 2019.

[3] FREIRE, Paulo. Extensão ou comunicação? 8aa ed. Rio de Janeiro: Paz e Terra, 1983. 


\section{Capítulo 8}

A compostagem como prática pedagógica para a efetivação da educação ambiental no ambiente escolar: Uma revisão de literatura

Benedito Aparecido de Castro

Francisco Giovani Souza Laércio

Lincoln de Souza Lopes

Thiago José Pimenta Alves

Letícia Rodrigues da Fonseca

Resumo: 0 ambiente escolar é um espaço onde a maioria dos assuntos da sociedade deve ser tratados. Dentre eles, destaca-se a Educação Ambiental e a temática de ações sustentáveis para a promoção de hábitos saudáveis levando a uma boa qualidade de vida. 0 estudo realizou-se com uma revisão de literatura no segmento de compostagem e resíduos orgânicos com o objetivo de analisar e discutir a produção científica brasileira sobre os processos de compostagem nas unidades escolares. Para isso foram selecionados dez artigos sobre o tema, publicados na base de dados da plataformas Scielo, Google Acadêmico e Portal Capes no período de 2015 a 2020. Por meio de técnicas de compostagem, os alunos compreendem a importância da separação dos resíduos orgânicos no ambiente escolar e na sociedade em geral. As atividades pedagógicas bem como ações interdisciplinares nas escolas, favorecem novas metodologias em favor da educação ambiental para a melhoria da qualidade de vida. Ações sustentáveis devem ser valorizadas dentro do espaço educacional, propondo uma melhor percepção do meio ambiente, e em especial o ciclo da matéria orgânica. As práticas de Educação Ambiental podem ser grandes aliadas como uma excelente metodologia no aprendizado, transformando em uma nova percepção de cuidados com o meio ambiente e assim ser replicadores de uma fator social favorável ao meio ambiente. Fatores como cuidados ambientais, estilo de vida e tratamento inadequado dos alimentos podem geram impactos no meio ambiente e atividades humanas, por isso a necessidade de propor novas ações pedagógicas e sustentáveis para uma melhoria da sociedade.

Palavras chave: Compostagem, Educação Ambiental, Resíduos Orgânicos, Ações Sustentáveis. 


\section{INTRODUÇÃO}

A compostagem pode ser definida como uma decomposição aeróbica acelerada e controlada de substratos orgânicos que permitam a ação de microorganismos, o produto final deste processo é enriquecedor ao solo, podendo ser aplicado para melhorar a qualidade do solo, sem contaminação ao meio ambiente.

Segundo VALENTE et .al (2009) os resíduos orgânicos compostáveis podem ser divididos em dois grupos. 0 grupo verde são aqueles que têm maior proporção de nitrogênio (C/N inferior a 30:1), alto teor de umidade e decomposição mais rápida que os castanhos; por exemplo: cascas de batata, resto de vegetais crus, restos de cascas de frutos, resto de pão, arroz e massas cozidas, restos de comidas cozinhadas e cascas de ovos esmagadas. Já o grupo castanho são aqueles que contêm maior proporção de carbono em relação ao nitrogênio ( $\mathrm{C} / \mathrm{N}$ superior a 30:1), cor acastanhado, baixo teor de umidade e de decomposição lenta; por exemplo: feno, palha, aparras de madeira e serragem, aparas de relva e erva seca, folhas secas, ramos pequenos e pequenas quantidades de cinza de madeira.

A construção de uma composteira de resíduos orgânicos no ambiente escolar, tem a finalidade de envolver toda a comunidade em questões ambientais e atitudes sustentáveis, principalmente com a justificativa sobre a disposição inadequadas dos resíduos orgânicos provenientes no espaço escolar.

Uma abordagem semelhante foi realizada por Costa e Silva (2012) que analisou a importância da compostagem na conservação da natureza, trazendo à tona a reflexão sobre o papel do método de reciclagem no cuidado com o ecossistema, tornando-se, assim, indivíduos mais críticos, melhorando suas atitudes e corrigindo hábitos errôneos acerca do meio ambiente. A proposição de temas relacionados a reciclagem tem o papel de despertar o pensamento ecológico dos estudantes com a introdução do pensamento de que todos nós fazemos parte do meio e o universo é o nosso ambiente. E ainda a compostagem como um instrumento pedagógico no ambiente escolar, engloba os princípios da educação ambiental, uma vez que, uma educação que se denomina ambiental deve ser pautada na visão sistêmica, onde todas as formas de vida e sistemas estão interligadas e interdependentes (CAPRA, 2006).

A compostagem como uma ação interdisciplinar no processo de aprendizagem devem unir a teoria com a prática, permitindo que o aluno seja o protagonista de ações sustentáveis e que possam ser considerados suas habilidades e competências no ambiente escolar, quando a relação entre conteúdo e cotidiano acontece o aluno sente -se motivado a prender e desenvolver o conhecimento, como elo de ligação para a estruturação de sua reflexão; seja social, cultural e ambiental. Em contrapartida, a separação dos resíduos orgânicos possibilita a realização da compostagem e, assim, a diminuição do descarte diário de resíduos orgânicos nos domicílios.

0 objetivo dessa pesquisa é realizar um levantamento bibliográfico que permita descrever como a compostagem pode ser utilizada para a efetivação da educação ambiental no ambiente escolar.

\section{REFERENCIAL TEÓRICO}

\subsection{EDUCAÇÃO AMBIENTAL CRÍTICA}

De acordo Pelicioni (1998), a Educação Ambiental tem o objetivo fundamental de transformar a mentalidade dos cidadãos de forma a enfatizar a importância e ao cuidado com o meio ambiente para a vida do ser humano e, principalmente, possibilitar a mudança do comportamento dos cidadãos, sendo esta transformação realizada através de ações. Além disso, a Educação Ambiental deve ser orientada para a formação do homem como cidadão e para contribuir com a melhora da qualidade de vida da própria população. E que segundo Reigota (2009), a Educação Ambiental inclui os princípios da sustentabilidade, da complexidade e da interdisciplinaridade.

A Educação Ambiental Crítica é uma vertente da Educação Ambiental visando formar o indivíduo na sua consciência plena sobre o meio do qual faz parte, sobre as causas e consequências da organização social no meio em que esse cidadão está inserido, transformando em um sujeito crítico social (GUIMARÃES, 2004).

A Educação Ambiental Crítica não está preocupada apenas com a preservação de espécies biológicas e com o equilíbrio biológico dos ecossistemas, que são aspectos importantíssimos, mas ela vai muito além disso, objetiva a reflexão das relações políticas, sociais, econômicas e culturais entre humanidade e natureza e as relações entre os seres humanos, no sentido de proporcionar aos indivíduos, o exercício da livre cidadania, capacitando-os a participem ativamente na busca de soluções que permitam a convivência digna de todas as espécies biológicas (REIGOTA, 2014). 
De acordo com Lima (2009), essa dissociação que estão envolvidas entre os aspectos biológicos e ecológicos juntamente com os aspectos políticos e sociais de uma crise ambiental devem ser argumentos centrais da Educação Ambiental Crítica que, partindo de outro fator, destacava o caráter estrutural e civilizatório da crise ambiental e a necessidade de mudanças e de respostas transformadoras tanto políticas, quanto éticas da questão ambiental de forma crítica. Segundo compreensão do indíviduo, os impactos ecológicos são apenas os efeitos de causas muito mais profundas que indicavam a degeneração de todo um modelo da civilização, baseado em opções políticas e valorativas predatórias e nocivas à vida social e natural, mas com um caráter crítico esse indivíduo passa a entender e compreender a importância a relação entre o ter e preservar o meio em que vive.

\subsection{O USO DA COMPOSTAGEM COMO PRÁTICA PEDAGÓGICA PARA A EFETIVAÇÃO DA EDUCAÇÃO AMBIENTAL}

O marco regulatório que diz respeito ao gerenciamento de Resíduos sólidos no Brasil foi a Política Nacional de Resíduos Sólidos (PNRS), aprovada em em 2010.

A partir da implementação da legislação, é dever dos municípios a procura de soluções a médio e longo prazo, para resíduos orgânicos e recicláveis que não deverão mais seguir para os aterros sanitários que estarão, por sua vez, autorizados a receber somente rejeitos. Os materiais orgânicos poderão ser encaminhados para a compostagem, respeitando a hierarquia da PNRS: "não geração, redução, reutilização, reciclagem e tratamento dos resíduos sólidos bem como a disposição final ambientalmente adequada dos rejeitos" (BRASIL, 2010, art. 3).

De acordo com Polzer apud Abrelpe (2014), o resíduo sólido doméstico típico de um brasileiro contém $51 \%$ do seu total composto por fração orgânica, o que representa um quantitativo significativo do total destinado aos aterros sanitários, ou mesmo lixões, ainda comumente utilizados para deposição de resíduos. Se esses materiais fossem desviados do aterro para a compostagem, poderiam gerar emprego e renda (por meio da venda) e principalmente, como a proposição aqui apresentada, interferir na conscientização da população, sobretudo crianças e adolescentes, na questão da sustentabilidade, com o reaproveitamento desses resíduos como fertilizantes em hortas, reduzindo custos e minimizando o impacto ambiental provocado pelo aterramento da matéria orgânica.

Os resíduos domésticos, são compostos por basicamente três frações em sua composição: sendo: matéria orgânica, materiais recicláveis, e, por fim, os rejeitos, que são aqueles resíduos que não podem ser encaminhados para a reciclagem ou para a compostagem.

Como exemplo de matéria orgânica, podem ser citados restos de comida, vegetais, cascas de fruta, borra de café, cascas de ovos, guardanapos sujos e outros, já os materiais recicláveis são compostos por papel, papelão, metais, vidros e plásticos. Neste estudo será aborda o processo de compostagem em ambiente escolar, portanto serão tidos como matéria prima para o processo de compostagem os resíduos orgânicos produzidos dentro da própria instituição de ensino.

De acordo com Vilela e Piesanti (2015) apude Kiehl (1998), "o processo de compostagem pode ser dividido em duas fases, denominadas degradação ativa e maturação ou cura. Alguns autores dividem esse mesmo processo em três fases distintas, conhecidas como decomposição, semimaturação e maturação ou humificação. A fase de semimaturação envolve o final da fase de degradação ativa e grande parte da fase de maturação, quando comparada às divisões em apenas duas fases. A compostagem envolve microorganismos bastante heterogêneos como fungos, bactérias, actinomicetos e anelídeos. Cada fase é assinalada pela ação principal desses micro-organismos numa certa temperatura."

Há uma variedade enorme de métodos para execução da compostagem que variam de acordo com o material utilizado. Segundo Vilela e Piesanti (2015) 0 método de compostagem em leiras estáticas com aeração natural se caracteriza pelo emprego de técnicas específicas, como o formato das leiras, o método estático e a cobertura das leiras. 0 diferencial deste método em relação ao formato das leiras são as paredes retas em relação ao solo, com formato retangular. Há também o sistema de leiras revolvidas que, de acordo com Crivelaro et al(2018), exige baixos valores de investimentos em sua implantação além de operar em baixos custos, entretanto deve-se destacar que o tamanho da leira deve ser dimensionado de tal maneira que haja capacidade de minimizar a perda de calor. 0 sistema de reatores biológicos é mais tecnificado, e exige maior capacidade técnica para operá-lo. 
Vale mencionar que em qualquer processo de compostagem é importante se ater a alguns parâmetros durante o processo. A decomposição da matéria orgânica depende do tempo e ainda de diversos fatores. À medida que o controle da compostagem aumenta, aumentará também a rapidez do processo. Todavia, essa influência não ocorre apenas no tempo de decomposição, mas também na maturação e qualidade do produto final. Destes fatores, destacam-se principalmente aqueles relacionados à inibição e/ou desenvolvimento da atividade microbiana, tais como, a umidade, a temperatura, o pH, a relação $\mathrm{C} / \mathrm{N}$, a aeração e a granulometria (PEDROSA ET. AL 2013).

De toda maneira, a ideia proposta é criar uma alternativa para reaproveitamento de restos de alimentos em uma unidade escolar, para tanto não é necessário altos investimentos e sim algo que realmente cubra essa lacuna do desperdício e aflore nos estudantes envolvidos, o sentimento da sustentabilidade.

\section{MATERIAL E MÉTODOS}

\subsection{PROCEDIMENTOS METODOLÓGICOS}

Segundo Richardson (1999) os procedimentos metodológicos são os caminhos previstos e percorridos pelo método científico durante uma pesquisa a partir da problematização de um tema. Em seguida a fase de justificativa da pesquisa os caminhos a serem tomados devem ser: a coleta , a observação, a interpretação e os resultados dos dados da pesquisa.

A pesquisa bibliográfica desse trabalho em Educação Ambiental tem o foco em ações sustentáveis com o tema de compostagem no ambiente escolar, justificando a formação profissional e pessoal de alunos da educação básica, afim de torná-los adultos e profissionais críticos e com responsabilidade ambiental e social.

A prática de compostagem de resíduos orgânicos como interdisciplinaridade deve ter uma estruturação dentro no ambiente escolar de acordo com a Figura 1.

Figura 1 - Sistematização do processo de compostagem

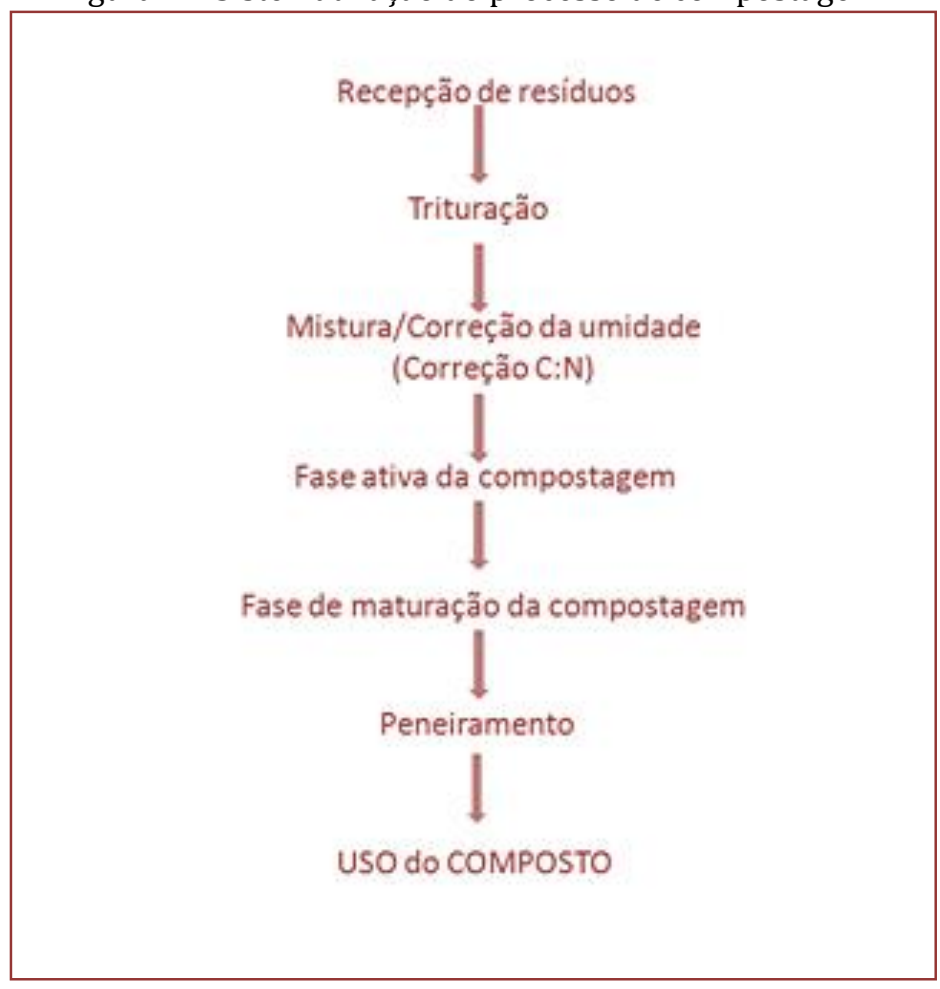

Fonte: Elaborado pelos autores 


\subsection{ABORDAGEM E TIPO DE PESQUISA}

0 tipo de pesquisa desse artigo quanto aos procedimentos é uma revisão de literatura. Uma pesquisa de revisão de literatura é um processo pelo qual se busca por análise e descrição, sobre um material científico ou tema relevante que foi publicado em artigos, periódicos, teses e dissertações. Para esse trabalho a pesquisa foi realizada em artigos científicos e periódicos sobre o tema de compostagem de resíduos orgânicos no ambiente escolar, como novas práticas e metodologias de educação, relacionando a produção científica em periódicos.

Segundo ALVEZ-MAZZOTTI (2002) a pesquisa de revisão de literatura, também conhecida por revisão bibliográfica tem dois propósitos fundamentais: a construção de um contexto para a justificativa do problema apresentado e a análise de possibilidades do tema presentes na literatura científica, seja para a produção de um referencial teórico ou estudo que já foi publicado sobre o tema. E ainda de acordo com França et al (2012) a partir da busca por revisão de literatura que favorecem a elaboração, validação e investigação sobre o tema a ser pesquisado.

\subsection{CARACTERIZAÇÃO DO LOCAL DA PESQUISA:}

Foi realizada uma busca de artigos científicos e ou artigos periódicos empregando a base de dados da biblioteca eletrônica SciELO, GOOGLE ACADÊMICO e PORTAL CAPES a fim de identificar artigos científicos publicados no período de 2015 a 2020 relacionados com o tema de compostagem de resíduos orgânicos no ambiente escolar, como forma de ações sustentáveis e trabalhando a interdisciplinaridade envolvendo a Educação Ambiental no ensino básico.

\subsection{MÉTODOS PARA COLETA DE DADOS}

A busca nas fontes supracitadas foi realizada tendo como os termos ligados aos indexadores das palavras chaves do tema proposto, descrito no resumo desse artigo . Os artigos referidos foram selecionados no idioma português (Brasil) . As publicações foram pré-selecionadas pelos títulos, os quais contém como o primeiro critério, o termo completo e ou com referências próximo do contexto do tema do referido artigo. A pesquisa foi realizada utilizando termos como "Compostagem e Resíduos Orgânicos", "Educação Ambiental" , "Ações Sustentáveis" e "Esses termos foram pesquisados separadamente e também a junção desses termos.

\subsection{MÉTODOS PARA ANÁLISE DE DADOS}

A pesquisa no portais das plataformas/portais Scielo, Google Acadêmico e Portal Capes foi feita com o intenção de conhecer os assuntos interligados direta e indiretamente com o tema proposto na pesquisa . A busca por esses artigos sobre o tema teve como intuito de ampliar o campo de conhecimento sobre o assunto. Ao final, serão pré selecionados 20 artigos mais relevantes sobre o tema e selecionados 10 artigos para compor esta revisão de literatura. Os artigos pré selecionados foram escolhidos de acordo com pesquisas e ligações próximas ao do tema e finalmente os artigos selecionados foram escolhidos pela importância do tema e ligação direta ao assunto da revisão de literatura que foi o objeto da pesquisa da revisão bibliográfica, obtendo informações relevantes sobre a percepção da iniciativa da compostagem na educação. Os 10 artigos selecionados para essa revisão de literatura estão numerados e descritos no Quadro 1. 
Quadro 1: Quadro dos artigos de revisão de literatura

\begin{tabular}{|c|c|c|c|c|c|}
\hline TÍTULO DO ARTIGO & $\begin{array}{l}\text { ANO - } \\
\text { Public } \\
\text { ação }\end{array}$ & $\begin{array}{l}\text { PORTAL DE } \\
\text { PESQUISA }\end{array}$ & $\begin{array}{l}\text { LOCAL REALIZAÇÃO } \\
\text { PESQUISA }\end{array}$ & $\begin{array}{c}\text { TIPO DE } \\
\text { PESQUISA }\end{array}$ & $\begin{array}{l}\text { PERÍODO } \\
\text { PESQUISA }\end{array}$ \\
\hline $\begin{array}{l}\text { Oficinas de compostagem: uma } \\
\text { proposta de educação } \\
\text { ambiental no IFPB - Campus } \\
\text { Cajazeiras e na ASCAMARC }\end{array}$ & 2015 & $\begin{array}{c}\text { Google } \\
\text { Acadêmico }\end{array}$ & $\begin{array}{l}\text { IFPB - Campus } \\
\text { Cajazeiras - PB }\end{array}$ & $\begin{array}{c}\text { Pesquisa } \\
\text { Experimental }\end{array}$ & 2012 \\
\hline $\begin{array}{l}\text { Conscientização ambiental em } \\
\text { escolas de educação básica por } \\
\text { meio da compostagem } \\
\text { transformando resíduos } \\
\text { orgânicos em húmus. }\end{array}$ & 2014 & $\begin{array}{c}\text { Google } \\
\text { Acadêmico }\end{array}$ & $\begin{array}{l}\text { Escola Estadual de } \\
\text { Ensino Médio } \\
\text { Cardeal Roncalli - } \\
\text { Frederico } \\
\text { Westphalen - RS }\end{array}$ & $\begin{array}{l}\text { Pesquisa } \\
\text { Experimental e de } \\
\text { Levantamento. }\end{array}$ & $\begin{array}{l}\text { Março de } \\
2012\end{array}$ \\
\hline $\begin{array}{l}\text { Plantando saúde: disseminando } \\
\text { técnicas de compostagem e } \\
\text { horta caseira em Mossoró/RN. }\end{array}$ & 2018 & $\begin{array}{l}\text { Portal Capes } \\
\text { - Periódicos. }\end{array}$ & $\begin{array}{l}\text { Instituto Federal do } \\
\text { Rio Grande do Norte } \\
\text { (IFRN) - Campus } \\
\text { Mossoró - RN }\end{array}$ & $\begin{array}{c}\text { Pesquisa de } \\
\text { Desenvolvimento. }\end{array}$ & $\begin{array}{l}\text { Outubro de } \\
\quad 2015\end{array}$ \\
\hline $\begin{array}{l}\text { Compostagem como uma } \\
\text { estratégia de redução dos } \\
\text { resíduos sólidos descartados } \\
\text { no ambiente escolar. }\end{array}$ & 2019 & $\begin{array}{c}\text { Google } \\
\text { Acadêmico }\end{array}$ & $\begin{array}{l}\text { Laboratório } \\
\text { Desenvolvimento } \\
\text { Infantil - Campus } \\
\text { UFV, Viçosa - MG }\end{array}$ & $\begin{array}{l}\text { Pesquisa Estudo } \\
\text { de Caso e } \\
\text { Experimental }\end{array}$ & $\begin{array}{l}\text { Junho de } \\
2018\end{array}$ \\
\hline $\begin{array}{l}\text { Promovendo a Educação } \\
\text { Ambiental através da } \\
\text { compostagem domiciliar }\end{array}$ & 2018 & $\begin{array}{l}\text { Portal Capes } \\
\text { - Busca } \\
\text { avançada }\end{array}$ & $\begin{array}{l}\text { "Projeto Solidário", } \\
\text { realizado pelo } \\
\text { Colégio Santa } \\
\text { Teresinha - Campo } \\
\text { Bom/RS }\end{array}$ & $\begin{array}{l}\text { Pesquisa de } \\
\text { levantamento }\end{array}$ & $\begin{array}{l}\text { Março de } \\
2018\end{array}$ \\
\hline $\begin{array}{l}\text { Horta viva: além dos muros da } \\
\text { Escola }\end{array}$ & 2016 & $\begin{array}{l}\text { Portal Capes } \\
\text { - Busca } \\
\text { avançada }\end{array}$ & $\begin{array}{l}\text { Escola Municipal } \\
\text { Nossa Senhora de } \\
\text { Fátima, localizada na } \\
\text { Zona da Mata de } \\
\text { Minas Gerais - } \\
\text { Muriaé - MG }\end{array}$ & $\begin{array}{l}\text { Pesquisa de } \\
\text { Campo }\end{array}$ & $\begin{array}{l}\text { Sem } \\
\text { informações } \\
\text { período } \\
\text { pesquisa. }\end{array}$ \\
\hline $\begin{array}{l}\text { Minicompostagem ecológica: } \\
\text { uma estratégia de educação } \\
\text { ambiental em escolas de } \\
\text { Educação Básica no município } \\
\text { de Lages/SC. }\end{array}$ & 2019 & $\begin{array}{c}\text { Google } \\
\text { Acadêmico }\end{array}$ & $\begin{array}{l}\text { Escolas de Educação } \\
\text { Básica da cidade de } \\
\text { Lages, no estado de } \\
\text { Santa Catarina. }\end{array}$ & $\begin{array}{l}\text { Pesquisa de } \\
\text { levantamento e } \\
\text { Experimental }\end{array}$ & $\begin{array}{l}\text { Entre } 2013 \\
\quad \text { e } 2015\end{array}$ \\
\hline $\begin{array}{l}\text { Compostagem versus } \\
\text { vermicompostagem: } \\
\text { comparação das técnicas } \\
\text { utilizando resíduos vegetais, } \\
\text { esterco bovino e serragem. }\end{array}$ & 2015 & Portal Scielo & $\begin{array}{l}\text { Faculdade de } \\
\text { Engenharia da } \\
\text { Universidade do } \\
\text { Estado de Minas } \\
\text { Gerais (UEMG), no } \\
\text { município de João } \\
\text { Monlevade (MG) }\end{array}$ & $\begin{array}{c}\text { Pesquisa } \\
\text { Experimental }\end{array}$ & $\begin{array}{l}\text { Sem } \\
\text { informações } \\
\text { período } \\
\text { pesquisa }\end{array}$ \\
\hline $\begin{array}{l}\text { Educação ambiental: a } \\
\text { conscientização sobre o destino } \\
\text { de resíduos sólidos, o } \\
\text { desperdício de água e o de } \\
\text { alimentos no município de } \\
\text { Cametá/PA }\end{array}$ & 2019 & Portal Scielo & $\begin{array}{l}\text { Área urbana do } \\
\text { município de } \\
\text { Cametá, estado do } \\
\text { Pará, região do Baixo } \\
\text { Tocantins, }\end{array}$ & $\begin{array}{l}\text { Pesquisa } \\
\text { Documental }\end{array}$ & 2016 \\
\hline $\begin{array}{l}\text { A prática da compostagem } \\
\text { como instrumento no ensino de } \\
\text { conteúdos e na Educação } \\
\text { Ambiental Crítica }\end{array}$ & 2019 & Portal Scielo & $\begin{array}{l}\text { Escola Municipal de } \\
\text { Ensino Fundamental } \\
\text { São Marcos, situada } \\
\text { no bairro São } \\
\text { Marcos, no } \\
\text { município da Serra - } \\
\text { ES }\end{array}$ & $\begin{array}{l}\text { Pesquisa de } \\
\text { Levantamento e } \\
\text { Experimental }\end{array}$ & $\begin{array}{l}\text { Maio a } \\
\text { Agosto de } \\
2017\end{array}$ \\
\hline
\end{tabular}




\section{RESULTADOS E DISCUSSÕES}

A principal intenção dessa revisão de literatura foi descrever uma ação sustentável que poderá ser praticada por escolas e que influenciará na conscientização acerca da importância da reutilização de resíduos orgânicos.

Dos artigos levantados (Tabela 1), todos atenderam aos quesitos propostos com o tema que envolve compostagem de resíduos orgânicos no ambiente escolar, proporcionado ações sustentáveis . Todos os artigos foram realizados no âmbito escolar envolvendo: alunos, professores, comunidade escolar e funcionários e gestores. Foram desenvolvidos em diferentes etapas do ensino e comunidades: três no Ensino Fundamental, três no Ensino Médio, três em Ambiente Familiar (em torno de Unidade Educacional) e um no Ensino Superior.

Os artigos desenvolvidos em ambientes educacionais, se destacaram por observações importantes:

- Apresentaram a interdisciplinaridade, explorando diversas áreas do conhecimento escolar como objetivo importante;

- Enfatizaram a compostagem como uma ferramenta metodológica que envolve a prática por uma ação protagonista do aluno e

- A composteira como instrumento pedagógico no ambiente escolar possibilitou também a disseminação da prática na comunidade em torno das unidades escolares, levando essa prática para o seu ambiente familiar.

Já os artigos que foram discutidos e envolvidos em comunidades/ ambientes familiar ( em torno de unidades escolares) destacou-se a importância dos cuidados com o meio ambiente e formas de renda para as famílias.

Os artigos que fizeram parte dessa revisão de literatura foram pesquisados em três plataformas de dados :SCIELO, GOOGLE ACADÊMICO e PORTAL CAPES. A pesquisa nesses portais/banco de dados levaram em conta a busca avançada. Foi feita a pesquisa levando em conta a forma de busca em todos portais, tais como:

- Todas palavras da pesquisa;

- $\quad$ Título de artigo;

- $\quad$ Exibir arquivos entre as datas (2015 - 2020);

- $\quad$ Pesquisar páginas em português (Brasil).

De acordo com a Quadro 2, apresenta o números de artigos encontrados entre os plataformas/portais descritos.

Quadro 2: Pesquisa/Plataformas no período (2015-2020) dos temas por palavras chaves

\begin{tabular}{|l|c|c|c|}
\multicolumn{1}{c|}{ TEMAS: PALAVRAS-CHAVES } & $\begin{array}{c}\text { PLATAFORMA } \\
\text { SCIELO }\end{array}$ & $\begin{array}{c}\text { PLATAFORMA } \\
\text { GOOGLE } \\
\text { ACADÊMICO }\end{array}$ & $\begin{array}{c}\text { PLATAFORMA } \\
\text { PORTAL CAPES }\end{array}$ \\
\hline $\begin{array}{l}\text { COMPOSTAGEM E RESÍDUOS } \\
\text { ORGÂNICOS }\end{array}$ & 37 & 10.900 & 52 \\
\hline $\begin{array}{l}\text { COMPOSTAGEM E EDUCAÇÃO } \\
\text { AMBIENTAL }\end{array}$ & 2 & 8.190 & 60 \\
\hline $\begin{array}{l}\text { COMPOSTAGEM E AÇÕES } \\
\text { SUSTENTÁVEIS }\end{array}$ & 2 & 7.960 & 40 \\
\hline $\begin{array}{l}\text { COMPOSTAGEM NO AMBIENTE } \\
\text { ESCOLAR }\end{array}$ & 3 & 6.540 & 19 \\
\hline
\end{tabular}

Fonte: Elaborado pelos autores

A justificativa para esses números em quantidade de publicações que se resgata no portal Google Acadêmico em relação a outros bancos de dados é porque é amplamente aceito pela comunidade científica. já o número do portal Scielo é menor, pelo fato de uma qualificação mais restrita pela classificação de aperfeiçoamento de pessoal de nível superior, Qualis/Capes. 


\section{CONSIDERAÇÕES FINAIS}

Após a pesquisa de revisão de literatura com o tema de Compostagem no ambiente escolar, podemos concluir:

- A compostagem de resíduos orgânicos representa um instrumento pedagógico importante e inovador dentro de uma unidade escolar;

- O levantamento bibliográfico indica que a compostagem é uma ferramenta de apoio e interdisciplinar durante o processo de aprendizagem, para a construção de uma Educação Ambiental Crítica;

- A compostagem promove uma excelente interação entre a comunidade escolar, provocando uma mudança de atitudes saudáveis, e em alguns momentos o fortalecimento da abertura de uma agricultura familiar e

- A atividade de Educação Ambiental como metodologia de ensino estimula hábitos saudáveis e contribui para a formação de cidadãos mais preocupados com a preservação do meio ambiente, em específico a preocupação em reaproveitamento dos resíduos orgânicos pelo processo de compostagem.

- $\quad$ Pretende-se com fundamento teórico aplicar com essa prática de educação ambiental como forma de efetivação de ações sustentáveis no ambiente escolar.

\section{REFERÊNCIAS}

[1] ALVES-MAZZOTTI, A. J. A "revisão bibliográfica" em teses e dissertações: meus tipos inesquecíveis - o retorno. In: BIANCHETTI, L.; MACHADO, A. M. N. (Org.). A bússula do escrever: desafios e estratégias na orientação de teses e dissertações. São Paulo: Cortez, 2002. p. 25-44

[2] BRASIL. Lei n. 12.305, de 2 de agosto de 2010. Institui a Política Nacional de Resíduos Sólidos; altera a Lei no 9.605, de 12 de fevereiro de 1998; e dá outras providências. Disponível em: . Acesso em: 05 Jul. 2020.

[3] CAPRA, F. Alfabetização Ecológica: A educação das crianças para um mundo sustentável. 1. ed. São Paulo: Cultrix, 2006.

[4] Costa, A.P. ; SILVA, W.S.M. Oficinas de Compostagem: uma proposta de educação ambiental no IFPB- Campus Cajazeiras e na ASCAMARC. Periodícos Instituto Federal da Paraíba. Divulgação Científica e Tecnologia do IFPB. João Pessoa - PB. № 21, dez,2012

[5] CRIVELARO, A. L.; MOREIRA, M. A.; DA SILVA, J. A. Gestão de Resíduos Sólidos e Compostagem Orgânica: Estudo de Caso para Escolha de Tecnologia de Processo em Macaé, Brasil. Boletim do Observatório Ambiental Alberto Ribeiro Lamego, v. 12, n. 1, p. 89-110, 20 jul. 2018.

[6] FRANÇA, C. L.; MATTA, K. W.; ALVES, E. D. Psicologia e educação a distância: uma revisão bibliográfica. Psicologia: Ciência \& Profissão, v. 32, n. 1, p. 4-15, 2012.

[7] GUIMARÃES M. Educação Ambiental Crítica. In: Layrargues PP, editor. Identidades da educação ambiental brasileira. Diretoria de Educação Ambiental. Brasília: Ministério do Meio Ambiente; 2004. p. 25-34.

[8] LIMA, G. F.C. Educação Ambiental Crítica: do Socioambientalismo ás sociedades sustentáveis. Educação e Pesquisa, São Paulo - SP, v35, n1, p 145- 163. Jan/Abr.2009.

[9] Pedrosa, T. D., Farias, C. A. S., Pereira, R. A., \& do Rêgo Farias, E. T. (2013). Monitoramento dos parâmetros físico-químicos na compostagem de resíduos agroindustriais. Nativa, 1(1), 44-48.

[10] PELICIONI, Maria Cecília Focesi. Educação ambiental, qualidade de vida e sustentabilidade. Saude soc., São Paulo, v. 7, n. 2, p. 19-31, dez. 1998.

[11] POLZER, V. COMPOSTAGEM: UMA NECESSIDADE DOS CENTROS URBANOS. Revista Brasileira de Ciências Ambientais (Online), n. 40, p. 124-136, 30 jun. 2016.

[12] REIGOTA, M. (Org.) Verde Cotidiano: o meio ambiente em discussão. 3. ed. Petrópolis: DP et Alii, 2008.

[13] REIGOTA, M. 0 que é Educação Ambietal. 2ª. ed. São Paulo: Brasiliense, 2014. - Coleção Primeiros Passos;

292.

[14] RICHARDSON, Roberto Jarry et al. Pesquisa Social : Métodos e Técnicas. 3a edição. Revista e Ampliada. São Paulo- SP, ATLAS, 1999

[15] TRIVELLA, Renato Barretto Barbosa et al. A Compostagem Termofilica como metodologia para restauração de áreas degradadas dentro de uma Unidade de Conservação, Florianópolis (SC). Cadernos de Agroecologia, [S.I.], v. 
10, n. 3, may 2016. ISSN 2236-7934. Disponível em: http://revistas.abaagroecologia.org.br/index.php/cad/article/view/19456 Acesso em: 06 july 2020.

[16] VALENTE, B.S.; XAVIER, E.G.; MORSELLI, T.B.G.A.; JAHNKE, D.S., BRUM Jr, B.S.; CABRERA, B.R.; MORAES, P. O.; LOPES, D.C.N. (2009) Fatores que afetam o desenvolvimento da compostagem de resíduos orgânicos. Archivos de Zootecnia, v. 58, p. 59-85.

[17] Vilela, D., \& Piesanti, J. (2015). Gerenciamento de resíduos sólidos orgânicos da UFGD em compostagem. $\begin{array}{lllll}\text { Revista Ciência } & \text { em } & \text { 28-39. } & \text { Recuperado }\end{array}$ https://ojs.unesp.br/index.php/revista_proex/article/view/1201/1166 


\title{
Capítulo 9
}

\section{Compostagem da cama de aviário após recria de poedeiras ${ }^{4}$}

\author{
Karoll Andrea Alfonso Torres-Cordido \\ Fernanda Gomes Linhares \\ João Pedro de Barros Reicao Cordido \\ Caroline Campelo da Silva Ribeiro \\ Guilherme Ribeiro \\ Pedro Cassuce Brandão
}

Resumo: A avicultura brasileira exerce grande participação na economia do país com grande participação em carne de frango e ovos. 0 resíduo das excretas de aves é muito rico em $\mathrm{N}$ e na fase de recria de poedeiras para produção de ovos, o estrume é incorporado à maravalha, tornando um material com uma relação $\mathrm{C} / \mathrm{N}$ muito interessante. $\mathrm{O}$ objetivo deste trabalho foi avaliar a eficiência do processo de compostagem, para a destinação correta da cama de aviários. Com isso, foi montada uma pilha de compostagem, no campo experimental da Universidade Estadual do Norte Fluminense - UENF, onde foi monitorado por 90 dias e foram avaliadas a temperatura, as características químicas e biológicas do produto. A temperatura manteve-se dentro do esperado, com valores mais altos na fase termofílica e depois decresceram até próximo da temperatura ambiente no final. A umidade manteve-se em $60 \%$. Quanto à composição química, ressalta-se que a relação $\mathrm{C} / \mathrm{N}$ ficou acima da ideal, porém com bons resultados de nutrientes como P205 e Ca. A redução dos microrganismos termotolerantes e a ausência de Salmonela sp., demostraram resultados satisfatórios do tratamento. Portanto, conclui-se que através do processo de compostagem é possível tratar o resíduo oriundo da fase de cria e recria de galinhas e dar uma destinação final correta, e que o composto obtido do processo, apresenta grande potencial agronômico, sendo necessários outros estudos com aplicabilidade deste nas diferentes culturas.

Palavras-chave: Ciclagem de nutrientes; Resíduos da Avicultura; Temperatura da compostagem.

\footnotetext{
${ }^{4}$ Capítulo formado por: A Introdução foi extraída da revisão da literatura da tese de uma das autoras: Linhares F.G. "Detecção de amônia em granja avícola e análise de gases estufa da compostagem de cama de frango", Tese de Doutorado apresentada ao Programa de Pós-Graduação em Ciências Naturais, do Centro de Ciência e Tecnologia da Universidade Estadual do Norte Fluminense Darcy Ribeiro, Campos dos Goytacazes, RJ. 2019.

A metodologia descrita, os dados de temperatura e composição do composto foram previamente publicados pelos autores no resumo "Tratamento de cama de frango através da compostagem" no $7^{\circ}$ Congresso Nacional do Meio Ambiente. 23 a 24 de setembro 2020 Poços de Caldas - MG - Brasil ISSN on-line $\mathrm{N}^{\circ}$ 2317-9686 - V. 12 N.1 2020, com alterações.

A análise dos dados de temperatura por modelagem matemática é original deste capítulo de livro
} 


\section{INTRODUÇÃO}

A atividade avícola brasileira exerce grande impacto na economia do país com grande participação no PIB nacional, pela produção de carne de frango e ovos, com mercados interno e externo. De acordo com a Associação Brasileira de Proteína Animal (ABPA) a produção de ovos no Brasil teve um crescente avanço na última década, com o equivalente a 28.851.931,850 unidades de ovos em 2010 para 49.055.709,215 unidades de ovos produzidos no último ano (2019). Em paralelo a isso, o consumo per capita dessa proteína também subiu nesse período de 148 / ano para 230 ovos / ano (ABPA, 2020).

0 resíduo das excretas de aves é muito rico em N. Na produção de ovos, quando a fase de recria (aves com até 17 semanas) é realizada no piso, em sistema de criação livre de gaiola (cage free) ou no tipo caipira, utiliza-se cama para cobrir o piso do galpão, usando-se como substrato geralmente a maravalha (serragem de madeira). Denomina-se cama todo o material distribuído em um galpão para servir de leito aos animais, de modo a evitar o contato direto deste com o piso. A cama absorve umidade do ambiente, e incorpora fezes, urina, penas, descamações da pele e restos de alimento que caem do comedouro. Outro papel da cama é contribuir para a redução das variações de temperatura do ambiente (ARAUJO; OLIVEIRA; BRAGA, 2007; AVILA; MAZZUCO; FIGUEIREDO, 1992). Este material deve apresentar propriedades como: ser de tamanho médio cerca de 3 a $4 \mathrm{~cm}$, material picado ou triturado, ter capacidade de absorver a umidade sem empastar e liberar facilmente para o ar essa umidade, ter baixa condutividade térmica, ter capacidade de amortecimento, mesmo sob alta densidade, ter baixo custo e disponibilidade (AVILA; MAZZUCO; FIGUEIREDO, 1992).

A demanda por técnicas para o destino correto dos resíduos da criação de aves cresce junto com os índices produtivos, e mitigar os efeitos das criações intensivas de aves sobre o meio ambiente é uma necessidade de muitas propriedades, principalmente de cunho familiar. Nesse tipo de propriedade a disposição dos resíduos gerados, como a cama e as carcaças das aves mortas, muitas vezes tornam-se um grande problema, pois o descarte inapropriado pode ocasionar a proliferação de vetores, como animais e insetos e de doenças indesejáveis, além de odores desagradáveis, que poluem o ambiente.

A compostagem é uma excelente estratégia para o uso desses resíduos, pois facilita o manejo, reduz o volume dos resíduos e a perda de nitrogênio. Um composto bem feito apresenta matéria orgânica transformada em húmus e atua, no solo, melhorando sua estrutura e dando a ele condições de armazenar maior quantidade de água, de ar e de nutrientes, para a nutrição das plantas (LUCON; CHAVES, 2004). É empregada desde os tempos antigos, nos quais gregos, romanos e povos orientais, empiricamente, sabiam que os resíduos orgânicos podiam ser retornados ao solo, contribuindo para a fertilidade deste. Somente a partir de 1920, o processo passou a ser pesquisado cientificamente por Albert Howard.

Esse sistema de reciclagem dos nutrientes é uma forma de acelerar a decomposição da matéria orgânica em relação ao que ocorreria no meio ambiente, melhorando as condições de atividade dos microrganismos (bactérias e fungos). Nesse processo, ocorre intensa proliferação, o que provoca aumento brusco na temperatura, momento chamado de fase termofílica da compostagem, a qual possui alto poder de destruir patógenos e sementes de plantas daninhas (ORRICO JÚNIOR; ORRICO; DE LUCAS JÚNIOR, 2009). Os sólidos biodegradáveis da matéria orgânica são convertidos para um estado estável que pode ser manejado, estocado e aplicado como adubo orgânico, sem efeitos nocivos ao meio ambiente, desde que utilizado na dosagem adequada (ORRICO; DE LUCAS JÚNIOR; ORRICO JÚNIOR, 2007).

Porém, para que a técnica da compostagem seja realmente eficiente no tratamento desses resíduos, é necessário ter um bom controle de parâmetros como a umidade e a temperatura. É importante que a temperatura se eleve até aproximadamente $60{ }^{\circ} \mathrm{C}$, pois assim será possível a eliminação dos microrganismos patogênicos e das sementes, porém se passar disto pode ocorrer a diminuição de fungos e bactérias que auxiliam na decomposição do material. A umidade e a aeração também são fatores que podem ter efeitos positivos ou negativos na compostagem.

A umidade do material em processo de compostagem pode ser medida indiretamente usando o método qualitativo e de uso prático chamado teste de mão, o qual indica a aridez ou escorrimento da amostra e é realizado da seguinte forma: Aperta-se uma amostra do material com a mão, e se a amostra estiver pulverulenta ao abrir a mão e não retiver a forma da sua mão, significa que está muito seco. Ao apertar a amostra, se escorrer líquido entre os dedos, significa que está muito úmido. Se ao abrir a mão a amostra for moldável e se fragmentar em apenas dois pedaços, significa que a umidade é ideal (SILVA, 2008). Sempre que necessário deve-se irrigar a pilha com água e revolver, para manter as condições umidade e temperatura adequadas. 
Os materiais para compostagem se dividem em duas categorias: os materiais ricos em carbono, que incluem lenhosos, como palhas, casca de árvores, podas do jardim, aparas de madeira, galhos de árvores, que são os responsáveis por fornecer a matéria orgânica e a energia para a compostagem. Enquanto a função dos materiais ricos em nitrogênio como as folhas verdes, estrumes de animais, urina, solos, restos de vegetais hortícolas e ervas é acelerar o processo de compostagem, porque o nitrogênio é necessário para o crescimento dos micro-organismos. A tabela 1 apresenta o teor de matéria orgânica (MO), relação $\mathrm{C} / \mathrm{N}$, concentração de Carbono $(\mathrm{C})$, Nitrogênio $(\mathrm{N})$, Pentóxido de fósforo $\left(\mathrm{P}_{2} \mathrm{O}_{5}\right)$ e Óxido de potássio $\left(\mathrm{K}_{2} \mathrm{O}\right)$ de alguns resíduos da agropecuária considerados como compostáveis (OLIVEIRA; SATORI; GARCEZ, 2008).

Tabela 1. Composição de alguns materiais empregados no preparo do composto (resultados em material seco a $\left.110^{\circ} \mathrm{C}\right)$.

\begin{tabular}{|lcccccc|}
\hline \multicolumn{1}{|c}{ MATERIAL } & $\begin{array}{l}\text { M.O. } \\
(\mathrm{g} / \mathrm{kg})\end{array}$ & $\mathrm{C} / \mathrm{N}$ & $\begin{array}{c}\mathrm{C} \\
(\mathrm{g} / \mathrm{kg})^{*}\end{array}$ & $\begin{array}{c}\mathrm{N} \\
(\mathrm{g} / \mathrm{kg})\end{array}$ & $\begin{array}{c}\mathrm{P}_{2} \mathrm{O}_{5} \\
(\mathrm{~g} / \mathrm{kg})\end{array}$ & $\begin{array}{c}\mathrm{K}_{2} \mathrm{O} \\
(\mathrm{g} / \mathrm{kg})\end{array}$ \\
\hline Ábacaxi (fibras) & 714,1 & $44 / 1$ & 396,0 & 9.0 & - & 4,6 \\
A.rroz (cascas) & 850,0 & $63 / 1$ & 472,5 & 7,5 & 1,5 & 5,3 \\
A.rroz (palhas) & 543,4 & $39 / 1$ & 304,2 & 7,8 & 5,8 & 4,1 \\
Bagaço de carne & 585,0 & $22 / 1$ & 327,8 & 14,9 & 2,8 & 9,9 \\
Bagaço de laranja & 225,1 & $18 / 1$ & 127,8 & 7,1 & 1,8 & 4,1 \\
Borra de café & 867,9 & $25 / 1$ & 477,5 & 19,1 & 1,7 & 0,2 \\
Capim-colonião & 910,3 & $27 / 1$ & 504,9 & 18,7 & 5,3 & - \\
Esterco de gado & 621,1 & $18 / 1$ & 345,6 & 19,2 & 10,1 & 16,2 \\
Esterco de galinha & 540.0 & $10 / 1$ & 304.0 & 30,4 & 47.0 & 18,9 \\
Feijão guandu & 959.0 & $29 / 1$ & 524,9 & 18,1 & 5,9 & 11,4 \\
Grama batatais & 908.0 & $36 / 1$ & 500,4 & 13,9 & 3,6 & - \\
Serrapilheira & 306,8 & $17 / 1$ & 163,2 & 9,6 & 0,8 & 1,9 \\
Serragem de madeira & 934,5 & $865 / 1$ & 519.0 & 0,6 & 0,1 & 0,1 \\
Torta de usina de açúcar & 787,8 & $20 / 1$ & 438.0 & 21,9 & 23,2 & 12,3 \\
Turfa & 398,9 & $57 / 1$ & 222,3 & 3,9 & 0,1 & 3,2 \\
\hline
\end{tabular}

M.O. - matéria orgânica; $\mathrm{C} / \mathrm{N}$ - relação carbono/nitrogênio.

Fonte: Adaptado de Kiehl (1981 e 1985) por (OLIVEIRA; SATORI; GARCEZ, 2008)

* o teor de C $(\mathrm{g} / \mathrm{kg})$ foi calculado com base na relação $\mathrm{C} / \mathrm{N}$ e teores de $\mathrm{N}$ informados pelo autor.

Oliveira e colaboradores explicam que a relação $\mathrm{C} / \mathrm{N}$ (peso em peso) ideal para a compostagem é frequentemente considerada como 30. Dois terços do carbono são liberados como dióxido de carbono $\left(\mathrm{CO}_{2}\right)$ que é utilizado pelos micro-organismos para obter energia e o outro terço do carbono em conjunto com o nitrogênio é utilizado para constituir as células microbianas (OLIVEIRA; SATORI; GARCEZ, 2008).

As perdas de nitrogênio durante o processo de compostagem dos materiais orgânicos podem ser muito altas (cerca de 50\%) principalmente em materiais com relação C/N baixa. Para Lampkin (1992 apud OLIVEIRA; SATORI; GARCEZ, 2008) uma boa compostagem necessita de uma relação C/N de 25 a 35 . Para relações $\mathrm{C} / \mathrm{N}$ inferiores, o nitrogênio ficará em excesso e poderá ser perdido como amônia causando odores desagradáveis. Para relações $\mathrm{C} / \mathrm{N}$ mais elevadas a falta de nitrogênio limitará o crescimento microbiano, o carbono não será todo degradado conduzindo a que a temperatura não aumente, e a que a compostagem se processe mais lentamente.

Quanto à umidade, é conveniente iniciar o processo de compostagem com umidade superior a 50\%, porque no processo ocorre secagem devido à evaporação de água pelo calor. 0 monitoramento da umidade é de extrema importância, pois se estiver baixa, a atividade biológica ficará reduzida, por outro lado, se estiver alta, a geração biológica será prejudicada, podendo ocorrer anaerobiose (respiração celular na ausência de oxigênio). Neste último caso, há mais produção de chorume, líquido resultante da atividade enzimática natural de resíduos orgânicos, podendo causar lixiviação (VILHENA, 2018).

Observando a composição do esterco de galinha, percebe-se que este resíduo tem o maior índice dentre os outros da Tabela 1 em nitrogênio, cerca de $30 \mathrm{~g}$ de $\mathrm{N}$ para cada kg de esterco. Além disso, tem maior teor de fósforo e potássio. 
Há três fases durante o processo de compostagem: uma primeira inicial e rápida do composto cru ou imaturo, seguida de uma segunda fase de semi-cura ou bioestabilização, a fim de atingir finalmente a terceira fase, a humificação, acompanhada da mineralização de determinados componentes da matéria orgânica. A Figura 1 relaciona essas fases com a temperatura do composto no tempo (KIEHL, 1998). Exibe também a relação da temperatura, o processo inicia à temperatura ambiente (fase mesófila). À medida que a ação microbiana se intensifica, a temperatura se eleva, atingindo $60^{\circ} \mathrm{C}$ (fase termófila). Neste momento são eliminados os micróbios patogênicos e sementes. Após esta etapa, a temperatura desce até a temperatura ambiente.

Figura 1. Evolução da cura do composto

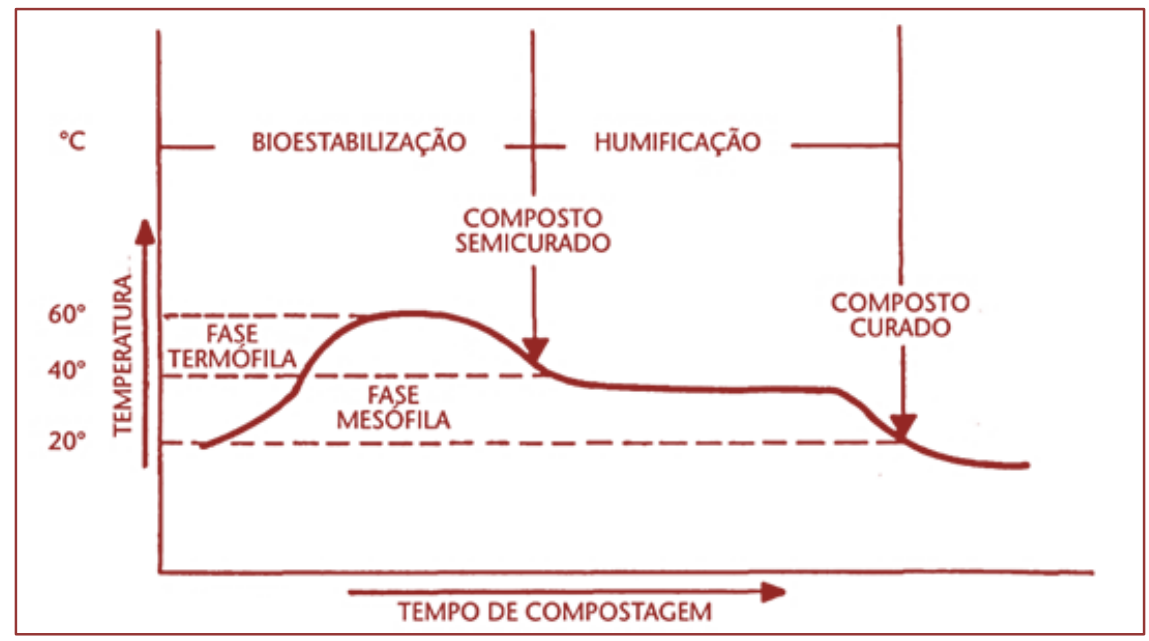

Fonte: (BELUSSO; HESPANHOL, 2010; KIEHL, 1998; VILHENA, 2018)

De acordo à Tabela 1, a serragem de madeira, também conhecido por maravalha, possui alto teor de matéria orgânica, ademais tem alta razão $\mathrm{C} / \mathrm{N}$, ajustando bem com o esterco de galinha que tem alto teor de nitrogênio, como já dito anteriormente.

Com base no exposto, foi avaliada a eficiência do processo de compostagem, para a destinação correta da cama de aviário utilizada nas fases de cria e recria de galinhas poedeiras, sendo, portanto, uma mistura composta principalmente de maravalha e esterco de galinha.

\section{METODOLOGIA}

\subsection{INSTALAÇÕES E MATERIAIS}

0 experimento foi realizado na Unidade de Apoio à Pesquisa (UAP) em Zootecnia da Universidade Estadual do Norte Fluminense Darcy Ribeiro (UENF), localizada na latitude 2119'23" (S) e longitude 411'ㄹ'” (W), no município de Campos do Goytacazes - RJ. O processo de compostagem foi conduzido por 92 dias, de 11 de julho a 11 de outubro de 2019.

A cama de aviário utilizada, foi proveniente da criação de 600 pintainhas, da linhagem de poedeiras comerciais NovoGen Brown, a partir do 1 dia de idade e pelo período de 100 dias, em densidade de 6 aves por $\mathrm{m}^{2}$. 0 substrato utilizado como cama foi maravalha de pinus, adquirida de fábrica comercial.

Depois da criação das aves foi confeccionada uma pilha com as seguintes dimensões: $2 \mathrm{~m}$ de largura, $1 \mathrm{~m}$ de comprimento e 1,2 m de altura. A pilha de compostagem foi montada a céu aberto, sendo coberta com uma lona e em contato direto com o solo. 
Figura 2. Maravalha de pinus usada como substrato para a cama do aviário onde foram recebidas pintainhas de um dia da linhagem Novogem. A profundidade da cama foi de $10 \mathrm{~cm}$. As aves permaneceram no aviário durante 14 semanas, correspondendo às fases de cria e recria.

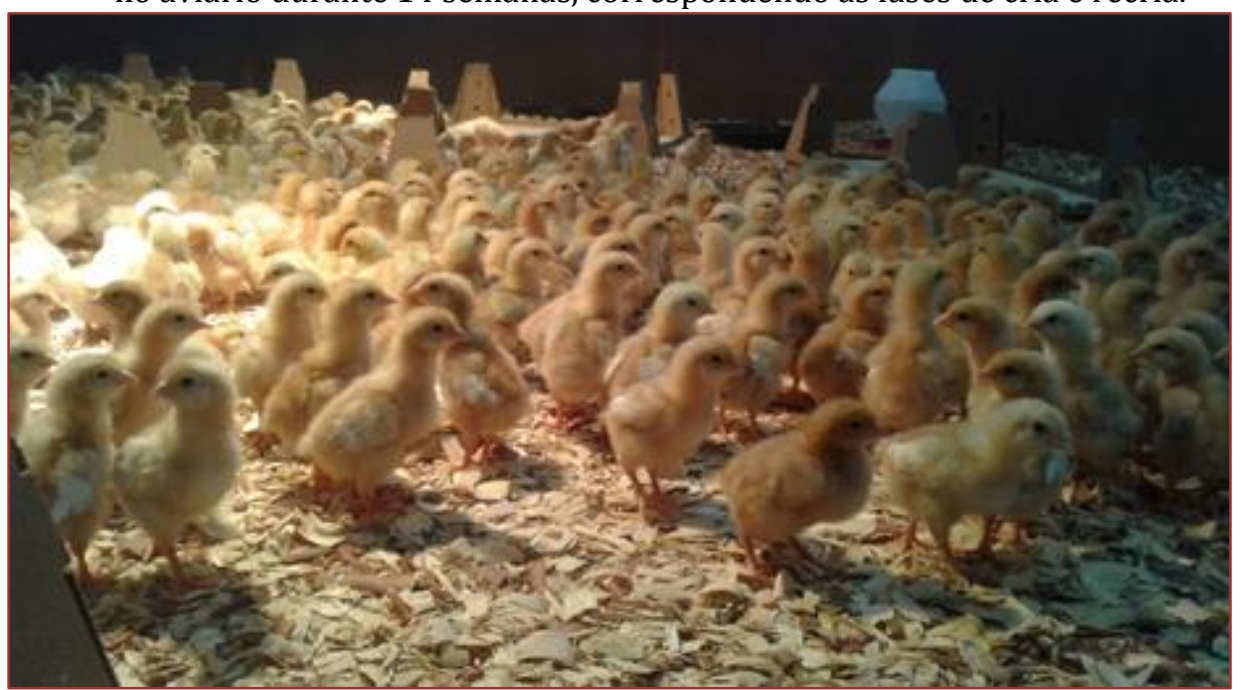

Figura 3. Pilha da cama do aviário no início do processo de compostagem

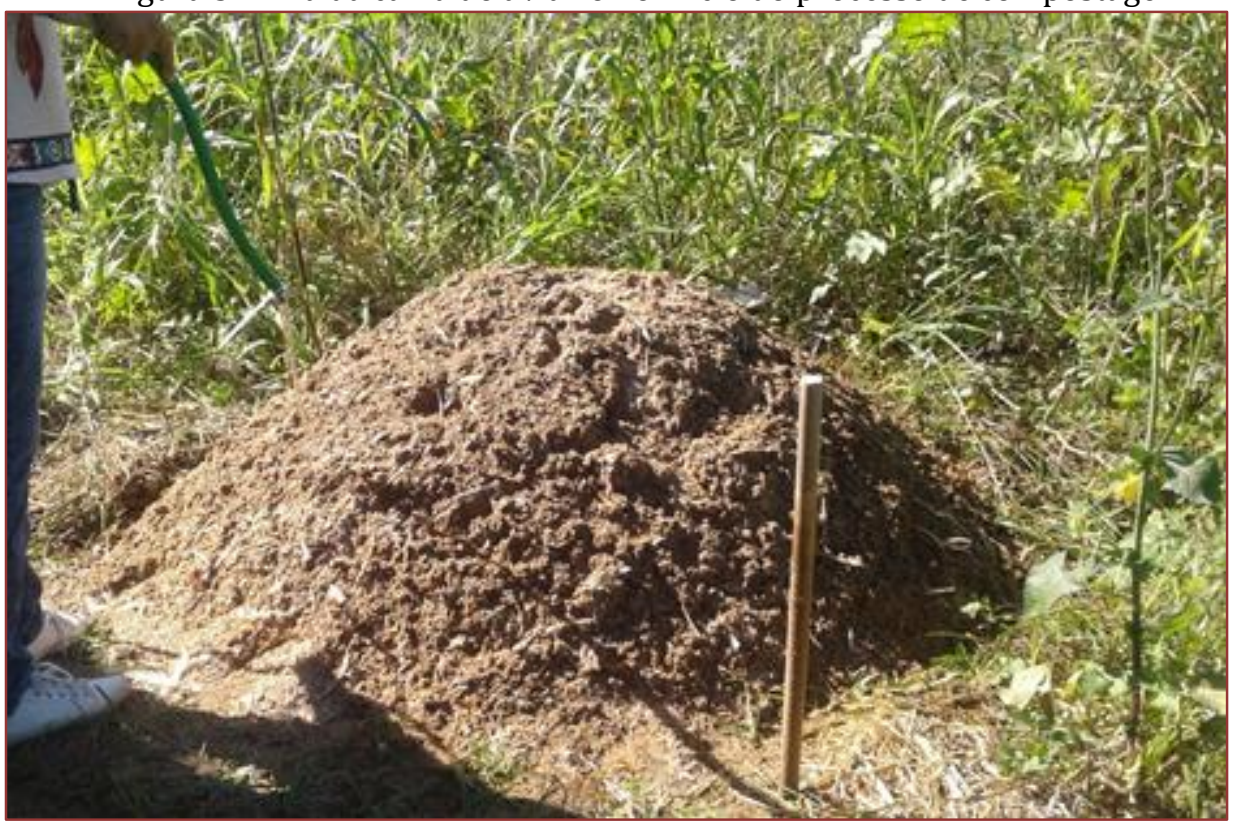

\subsection{TEMPERATURA DO COMPOSTO}

Aferiu-se a temperatura da pilha utilizando um termômetro digital, cujo sensor externo foi introduzido em um orifício feito na pilha, com o auxílio de uma haste de madeira, à profundidade de 0,5 m. Os registros de temperatura foram obtidos a cada 3 a 4 dias, partir da montagem até obter valores próximos à temperatura do ambiente. No final foram realizados registros mais espaçados para ter certeza da estabilização e que não houvesse novo ciclo de atividade. Foi realizado um estudo descritivo do comportamento da temperatura ao longo do tempo de compostagem. Os valores de temperatura foram transformados para inferir o crescimento dos micro-organismos, bem como a produção de biomassa destes. 


\subsection{COMPOSIÇÃO E QUALIDADE MICROBIOLÓGICA DO PRODUTO DA COMPOSTAGEM}

Uma vez concluído o período de compostagem coletou-se uma amostra do produto para análise da composição química e da presença de micro-organismos patógenos no composto. As amostras foram processadas por Laboratório comercial.

\section{RESULTADOS E DISCUSSÃO}

\subsection{TEMPERATURA}

Na Figura 4 são apresentados os valores observados da temperatura da pilha durante o período experimental. Na primeira semana, quatro dias depois da formação da pilha, a temperatura atingiu a fase termofílica, com o registro da temperatura média de $65,9^{\circ} \mathrm{C}$ e manteve-se nessa fase durante 35 dias, apresentando temperatura média e desvio padrão de $65,4 \pm 5$ ํㅡ, e valores mínimo e máximo de $57,7^{\circ} \mathrm{C}$ e $75,7^{\circ} \mathrm{C}$, respectivamente, durante a fase. 0 pico de temperatura de $75,7^{\circ} \mathrm{C}$ foi registrado aos 21 dias do início da fase termofílica, antes do revolvimento da pilha nesse dia, indicando a necessidade desse manejo, porque em temperatura muito alta pode ocorrer morte de micro-organismos benéficos para o processo de compostagem, o que não é interessante já que impede que a compostagem culmine todas as fases. Quando ocorreu o revolvimento e a irrigação da massa, os valores de temperatura retornaram aos esperados para fase termofílica. A segunda fase da compostagem iniciou após 42 dias de formação da pilha, e foi caracterizada pelo registro de queda gradativa da temperatura de $61^{\circ} \mathrm{C}$ a $33^{\circ} \mathrm{C}$, o que aconteceu ao longo de 53 dias, atingindo assim, a fase de cura, também chamada de humificação, de acordo com (KIEHL, 1998).

Figura 4. Valores observados de temperatura de uma pilha de cama de aviário à profundidade de $0,5 \mathrm{~m}$.

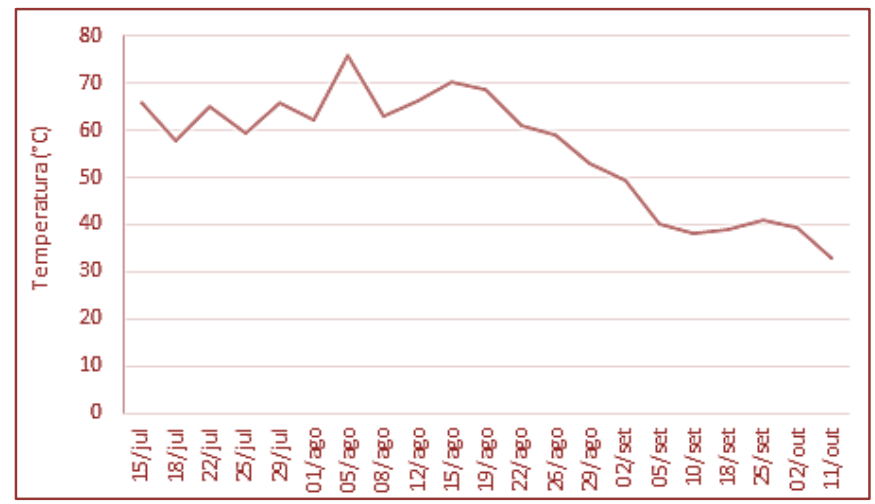

\subsection{COMPOSIÇÃO QUÍMICA E RELAÇÃO C/N}

Os resultados obtidos da relação $\mathrm{C} / \mathrm{N}$, nos indicam valores um pouco acima do ideal. Este fato pode estar relacionado a utilização da cama, pois ela foi utilizada na fase de cria, por um período de 100 dias, conforme mencionado na metodologia e no início do experimento era possível identificar uma grande quantidade de serragem no material.

Segundo Kiehl (1998), o acompanhamento da relação C/N durante a compostagem permite conhecer o andamento do processo, pois quando o composto atinge a semicura, ou bioestabilização, a relação $\mathrm{C} / \mathrm{N}$ se situa em torno de 18/1, e quando atinge a maturidade, ou seja transformou-se em produto acabado ou humificado, a relação $\mathrm{C} / \mathrm{N}$ se situa em torno de 10/1.

Ao avaliarem a compostagem dos resíduos da produção avícola como cama de frangos e carcaças de Aves, Orrico Junior et al. (2010), observaram as maiores perdas de N $(54,1 \%)$, na fase termofílica, onde ocorrem as temperaturas mais elevadas.

Tabela 2. Composição química ( $\mathrm{g} \mathrm{kg}^{-1}$ ) e pH do composto orgânico.

\begin{tabular}{|l|l|l|l|l|l|l|l|l|l|l|l|l|l|l|}
\hline $\mathrm{N}$ & $\mathrm{P}_{2} \mathrm{O}_{5}$ & $\mathrm{~K}_{2} \mathrm{O}$ & $\mathrm{Ca}$ & $\mathrm{Mg}$ & $\mathrm{Fe}$ & $\mathrm{Cu}$ & $\mathrm{Zn}$ & $\mathrm{Mn}$ & $\mathrm{S}$ & $\mathrm{B}$ & $\mathrm{CO}$ & $\mathrm{U}$ & $\mathrm{pH}$ \\
12,5 & 34 & 98 & 20 & 6,0 & 21,6 & 0,1 & 0,3 & 0,5 & 0,2 & 0,02 & 224,4 & 310,8 & 8,6 \\
\hline
\end{tabular}


Conforme os resultados apresentados na Tabela 2, os valores indicam que o composto produzido a partir da cama de frango, tem um grande potencial de uso agronômico, devendo ser realizados ensaios posteriores, pois o composto orgânico pode ser usado como um condicionador de solo, melhorando as características físicas, químicas e biológicas e garantido reforço e fertilidade do solo.

\subsection{MICROBIOLOGIA DO PRODUTO DA COMPOSTAGEM}

Os resultados demostraram a eficiência da compostagem no tratamento do resíduo (cama de frango), pois houve a remoção dos coliformes durante o período de enleiramento, com valores finais igual $1 \mathrm{NMP} / \mathrm{g}$ MS de coliformes termotolerantes e sem presença de Salmonella sp.

A redução dos números de patógenos no produto final, que será retornado ao solo, é um fator importante, pois a ocorrência de altos níveis de bactérias do grupo coliformes, na água de consumo, pode sujeitar as propriedades a maiores taxas de incidência de doenças nos animais, com consequente aumento da mortalidade e diminuição da produtividade (SALMINEN; RINTALA, 2002).

\section{ESTUDO DOS REGISTROS DE TEMPERATURA}

A temperatura do composto reflete a energia biotérmica gerada pelo crescimento microbiano, por isso, a sua mensuração ao longo do processo é uma forma indireta de determinar as fases de crescimento microbiano durante a compostagem. Por outro lado, o valor absoluto da leitura corresponde à somatória da temperatura do ambiente mais a energia metabólica, o que em condições experimentais seria possível separar, usando um tratamento controle no qual seriam dadas as mesmas condições da pilha para compostagem, porém sem desenvolvimento microbiano.

Esta foi uma experiencia de campo, por tanto, foi necessário criar uma estratégia para se aproximar da temperatura basal, que consistiu na correção das leituras efetuadas. A menor leitura do período foi considerada a temperatura basal, e cada valor transformado correspondeu à diferença do respectivo valor observado menos a temperatura basal. Posteriormente, com os valores transformados foram calculados os valores acumulados ao longo do tempo. Com os dados transformados foi gerado um modelo sigmoidal logístico e obtidos as fases de interesse biológico pela determinação dos pontos P1, P2 e P3, descritos por Cordido (2019): 1) Fase inicial, que neste caso corresponderá à fase de latência do crescimento microbiano, onde há maior disponibilidade de nutrientes e pouca produção de biomassa, e ocorre do início do processo até o ponto ou momento P1.2) Intermediária, fase com maior produção de biomassa, que ocorre entre o P1 e o P3, há um instante nesta fase que a velocidade de produção de biomassa é máxima (P2). 3) Final, onde há estabilização da produção de biomassa e esgotamento de recursos do meio, ocorre após o P3 (Figura 5).

Figura 5. Estimativa do crescimento microbiano ao longo da compostagem a partir dos valores transformados da temperatura da compostagem.

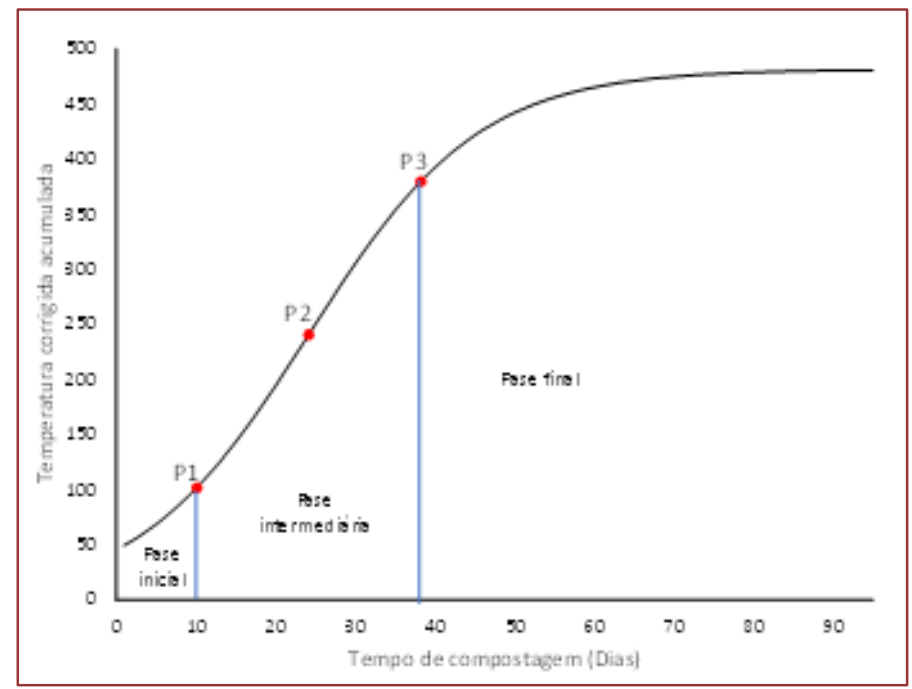


Quadro 1. Parâmetros da curva do modelo sigmoidal logístico

\begin{tabular}{|c|c|c|c|}
\hline a & b & C & R2 \\
\hline 481,108678 & 9,604890 & 0,093658 & 0,998 \\
\hline
\end{tabular}

Quadro 2. Pontos de interesse biológico para delimitação das fases de crescimento (Cordido, 2019).

\begin{tabular}{|c|c|c|}
\hline P1 & P2 & P3 \\
\hline 10,09 & 24,15 & 38,22 \\
\hline
\end{tabular}

Por fim, quando cruzados os dados observados e os gerados pelo modelo (Figuras 4 e 5) se observou que as tendências são coincidentes, o P3 e a fase de estabilização ocorreram no mesmo momento, a partir do qual começou a diminuição da temperatura observada e a curva gerada pelo modelo refletiu o início da fase de esgotamento de recursos do meio, inferindo-se como consequência, a redução da taxa de crescimento microbiano (Figura 6).

Figura 6. Estimativa dos valores transformados de temperatura (curva azul) e dados observados (pontos pretos) da temperatura da pilha durante a compostagem

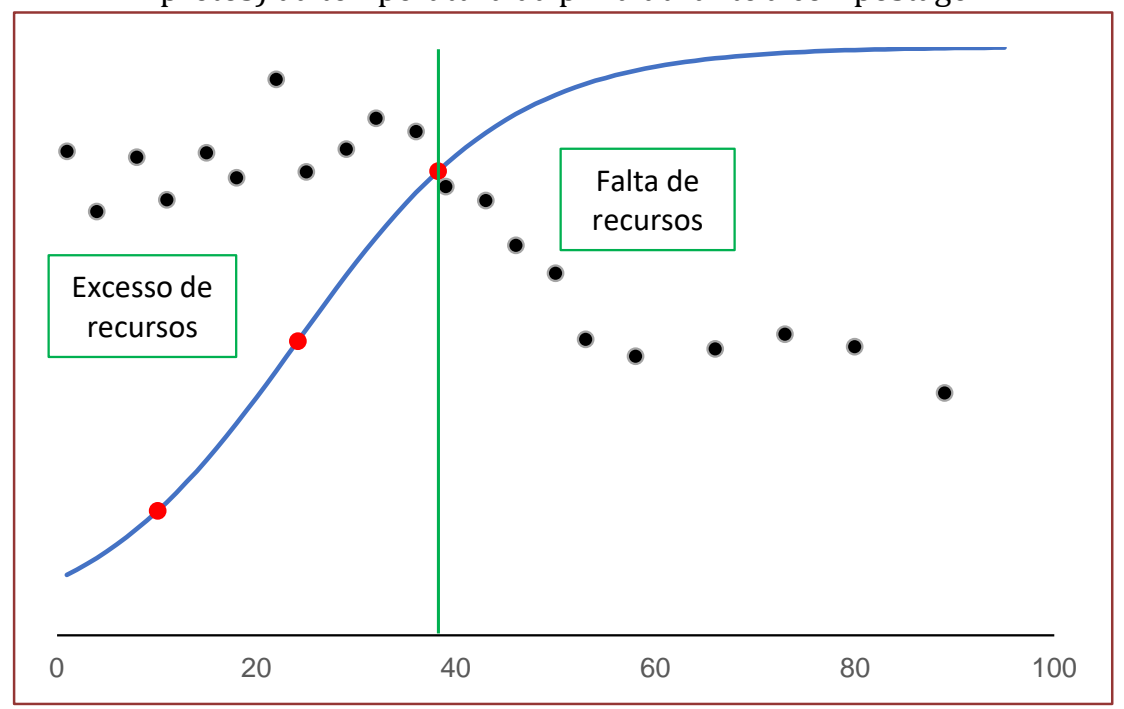

\section{CONSIDERAÇÕES FINAIS}

De acordo com o objetivo proposto, foi possível através do processo de compostagem tratar o resíduo oriundo da recria de galinhas e dar uma destinação final correta.

Os resultados demonstram que o composto obtido do processo, apresenta grande potencial agronômico, sendo necessários outros estudos com aplicabilidade deste nas diferentes culturas.

Com relação ao material utilizado, cama de aviário após períodos de cria e recria de galinhas poedeiras, foi possível concluir que, a cama quando não estiver saturada pelo uso, ou seja, pouco dejeto das galinhas devido à faixa etária e tempo de alojamento, pode ser misturada com outros resíduos mais ricos em nitrogênio, para que o composto tenha uma relação $\mathrm{C} / \mathrm{N}$ mais baixa.

A compostagem de resíduos é uma prática que permite combater problemas ambientais, relacionados ao destino e uso desses resíduos, e ao mesmo tempo prover para a agricultura grandes quantidades de adubo orgânico com a qualidade e benefícios relatados anteriormente.

\section{AGRADECIMENTOS}

Aos produtores de ovo caipira da região Norte Fluminense. À Universidade Estadual do Norte Fluminense Darcy Ribeiro -UENF pelo apoio e espaço cedido para a realização do trabalho e à Pró-reitoria de Extensão e Assuntos Comunitários da UENF pelas bolsas concedidas. 


\section{REFERÊNCIAS}

[1] ABPA. Relatório Anual. Associação Brasileira de Proteína Animal, p. 160, 2020.

[2] ARAUJO, J. DOS S.; OLIVEIRA, V. DE; BRAGA, G. C. Desempenho de frangos de corte criados em diferentes tipos de cama e taxa de lotação. Ciência Animal Brasileira, v. 8, n. 1, p. 59-64, 2007. AVILA, V. S. DE; MAZZUCO, H.; FIGUEIREDO, E. A. P. DE. Cama de aviário: Materiais, reutilização, uso como alimento e fertilizante: Circular Técnica. Concórdia, SC: [s.n.].

[3] BELUSSO, D.; HESPANHOL, A. N. A evolução da avicultura industrial brasileira e seus efeitos territoriais. Revista Percurso, v. 2, n. 1, p. 25-51, 2010.

[4] CORDIDO J.P.B.R. Eficiências nutricionais máximas e mínimas em povoamentos de eucalipto no brasil e sua modelagem. Tese de doutorado em Solos e Nutrição de Plantas. Universidade Federal de Viçosa. Viçosa, MG. 2019.

[5] KIEHL, E. J. Manual de Compostagem - Maturação e Qualidade do composto. Editado pe ed. Piracicaba, SP: [s.n.]. LUCON, C. M. M.; CHAVES, A. L. R. Horta orgânica. Biológico, v. 66, n. 1, p. 59-62, 2004.

[6] MORAES, T. P. D. E. Estudo Dos Aspectos Físico-Químicos Da Compostageme à Base da Casca de Mandioca. [s.l.] Universidade Tecnológica Federal do Paraná, 2014. OLIVEIRA, E. C. A. DE; SATORI, R. H.; GARCEZ, T. B. Compostagem. Piracicaba, SP: [s.n.].

[7] ORRICO, A. C. A.; DE LUCAS JÚNIOR, J.; ORRICO JÚNIOR, M. A. P. Alterações físicas e microbiológicas durante a compostagem dos dejetos de cabras. Engenharia Agricola, v. 27, n. 3, p. 764-772, 2007.

[8] ORRICO JÚNIOR, M. A. P.; ORRICO, A. C. A.; DE LUCAS JÚNIOR, J. COMPOSTAGEM DA FRAÇÃO SÓLIDA DA ÁGUA RESIDUÁRIA DE SUINOCULTURA. Engenharia Agricola, v. 29, n. 3, p. 483-491, 2009.

[9] ORRICO JÚNIOR, M. A. P.; ORRICO, A. C. A.; DE LUCAS JÚNIOR, J. COMPOSTAGEM DOS RESÍDUOS DA PRODUÇÃO AVÍCOLA: CAMA DE FRANGOS E CARCAÇAS DE AVES. Engenharia Agricola, v. 30, n. 3, p. 538-545, 2010.

[10] SALMINEN, E.; RINTALA, J. Anaerobic digestion of organic solid poultry slaughterhouse waste - A review. Bioresource Technology, v. 83, n. 1, p. 13-26, 2002.

[11] SERPA FILHO, R. et al. Compostagem de Dejetos de Suínos. Revista em Agronegocio e Meio Ambiente, v. 6, n. 1, p. 47-78, 2013.

[12] SILVA, L. R. E. COMPACTAÇÃo DO SOLO. [s.l.] Universidade São Francisco, 2008.

[13] VILHENA, A. Lixo Municipal: Manual de Gerenciamento Integrado. 4a ed. ed. São Paulo: CEMPRE, 2018. 


\section{Capítulo 10}

\section{Caracterização de cinza de casca como precursor de sílica}

\section{Paula Irigon de Irigon \\ Mirian Dosolina Fuzinatto \\ Pedro José Sanches Filho \\ Lucas Bonan Gomes \\ Amanda Ramos Pauletto}

Resumo: A casca de arroz é um resíduo produzido em quantidades significativas em nível global. Embora utilizado como combustível em fornos de engenho, cinzas provenientes desse processo constituem um passivo ambiental, em virtude da baixa reatividade pozolânica e alto potencial de lixiviação. Uma alternativa, que vem sendo testada com diversos tipos de cinzas, com bastante sucesso, é a obtenção de sílica pelo método sol-gel. Este método de extração alcalina baseia-se no comportamento de solubilização (hidrólise) e condensação do ácido silícico, portanto, diretamente relacionado ao teor de sílica amorfa do material. 0 principal objetivo deste estudo é determinar o percentual amorfo da sílica contida em dois tipos de cinza de casca de arroz e, assim, definir o rendimento máximo da extração de sílica pelo método sol-gel, para cada resíduo. A cinza de pirólise foi obtida a partir da termo conversão, em reator de leito fixo aquecido a $650{ }^{\circ} \mathrm{C}$ e atmosfera de nitrogênio com fluxo de $35 \mathrm{~mL}$.min-1. A cinza de engenho provém da queima direta, não controlada e temperatura aproximada de $800{ }^{\circ} \mathrm{C}$, nos fornos de engenho. 0 teor de sílica amorfa é calculado pelo Método de Rietveld, em conjunto com método do Padrão Interno, baseados na difratometria de raios X das cinzas. Os resultados apontam cinzas de pirólise 100\% amorfas e índice de amorfismo superior a $87 \%$ nas cinzas de engenho. Conclui-se que a cinza de pirólise apresenta maior grau de amorfismo e que ambas as cinzas apresentam potencial como precursores de sílica pelo processo sol-gel.

Palavras-chave: Cinza de casca de arroz; Método Rietveld; Análise quantitativa; Sílica amorfa. 


\section{INTRODUÇÃO}

A cinza de casca de arroz (CCA) queimada nos engenhos é um passivo ambiental. Uma alternativa que vem sendo usada para o reaproveitamento de cinzas é a obtenção de sílica pelo processo sol-gel. (ADEBISI et al., 2019; ASIM et al., 2019; IMOISILI; UKOBA; JEN, 2020; IRIGON et al., 2019). A extração de sílica pelo método sol-gel está intimamente ligada aos mecanismos de dissolução da sílica. Em água pura a solubilidade da sílica cristalina $\left(25^{\circ} \mathrm{C}\right)$ apresenta-se na ordem de $6 \mathrm{mg} / \mathrm{L}$, enquanto a sílica amorfa anidra e não porosa apresenta solubilidade de $70 \mathrm{mg} / \mathrm{L}$ e sílicas amorfas em pó apresentam solubilidade entre 100 - $130 \mathrm{mg} / \mathrm{L}$ de $\mathrm{SiO}_{2}$. Em soluções de pH superior a 10,7 a solubilidade da sílica amorfa chega a $876 \mathrm{mg} / \mathrm{L}$ (ILER, 1979). Portanto, para caracterização de CCA a determinação da quantidade de sílica amorfa é fundamental.

Este estudo analisa a CCA obtidos em dois tipos de queima distintos: a queima direta, em fornos de engenho e a queima pelo processo de pirólise. A determinação do percentual amorfo da sílica contida nas cinzas é obtida com base nos resultados das análises de Difração de Raios X (DRX) e o método Rietveld em conjunto com o método do padrão interno.

O principal objetivo desta pesquisa é quantificar o percentual de sílica amorfa nas cinzas de casca de arroz para avaliar o potencial das mesmas como material precursor de nano sílica pelo método sol-gel.

\section{METODOLOGIA}

A amostra de pirólise é oriunda de um projeto piloto do IFSUL/Campus Pelotas, onde a casca de arroz é submetida a termo conversão, sob fluxo de nitrogênio, em temperatura controlada $\left(650^{\circ} \mathrm{C}\right)$. A amostra de cinza de engenho foi fornecida por uma indústria de beneficiamento de arroz local. A queima acontece a aproximadamente $800^{\circ} \mathrm{C}$, de forma menos controlada e desigual.

A determinação do teor de sílica amorfa foi realizada com base na análise DRX, através do método de Rietveld em conjunto com o método do padrão interno. Ambos processos foram realizadas no Instituto de Geociências da Universidade Federal do Rio Grande do Sul (UFRGS).

O Método de Rietveld é reconhecido como uma ferramenta poderosa na análise estrutural de materiais policristalinos, baseado no refinamento de parâmetros instrumentais e da amostra, definidos a partir de modelos matemáticos (GOMES, 2016). Contudo, o método de Rietveld não possibilita o cálculo de percentual de fase amorfa presente na amostra. Por isso, foi utilizado o método do Padrão Interno, para auxiliar na quantificação de fases das amostras estudadas, já que estas apresentam amorfismo.

0 método do padrão interno consiste na adição de uma substância de referência, para auxiliar no refinamento do cálculo do percentual amorfo (CORDEIRO; MASUERO; DAL MOLIN, 2014). Para as análises deste trabalho, o padrão interno utilizado foi a zincita ( $\mathrm{ZnO}$ ), com percentual de $60 \%$ de massa da amostra (figura 01).

Figura 2: Difratograma da zincita (ZnO) (SHINDE et al., 2018)

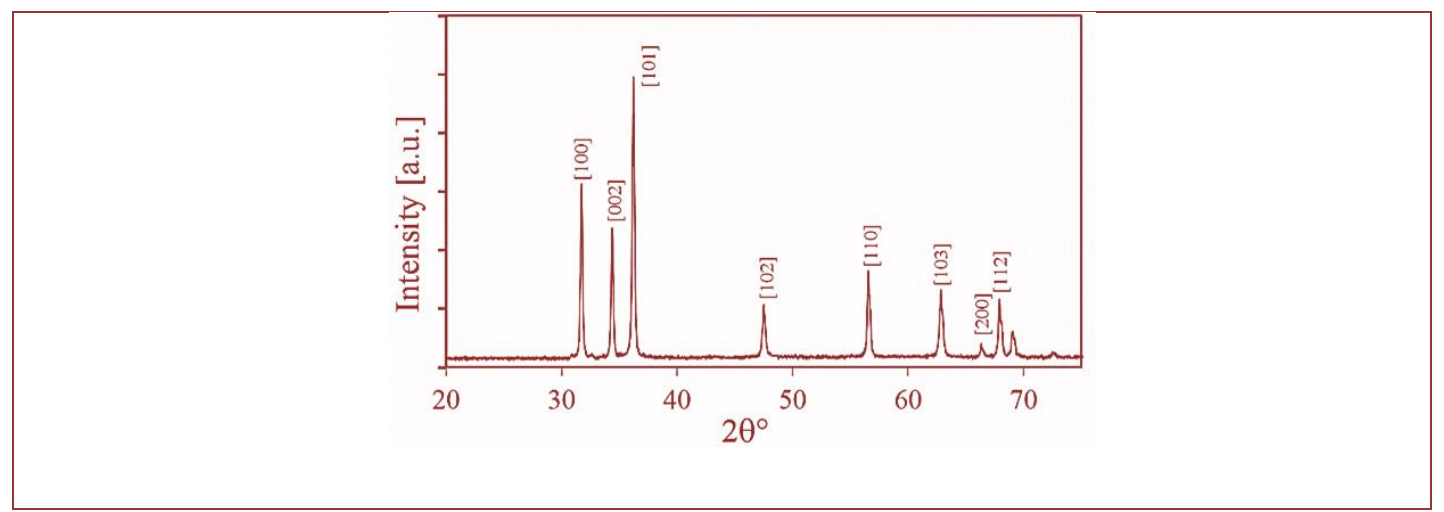




\section{RESULTADO E DISCUSSÃO}

0 resultado da análise de DRX da cinza de engenho (CCAE) é apresentado na figura 2, onde se identifica os picos cristalinos referentes ao padrão interno $(60 \% \mathrm{ZnO})$, além do halo característico da presença de sílica amorfa localizado entre as posições $2 \theta 15^{\circ} \mathrm{e} 30^{\circ}$.

Figura 2 - Difratograma da amostra CCAE

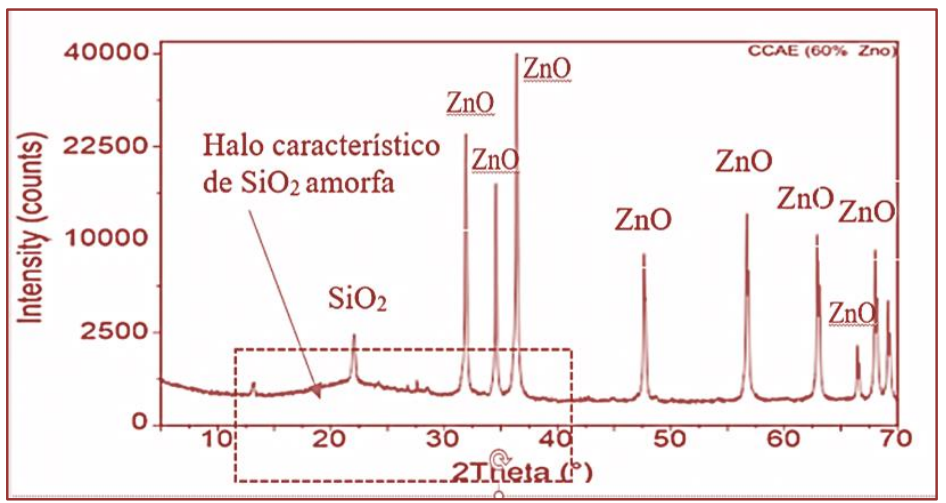

Pesquisas com cinza de casca de arroz identificam sílica amorfa em CCA pela presença de três ondulações, com picos definidos em torno de $2 \theta=16,22$ e $35^{\circ}$, típicos de celulose I, não hemicelulose e lignina, em fase amorfa. (JOHAR; AHMAD; DUFRESNE, 2012; SANTANA COSTA; PARANHOS, 2018). Muitos autores ressaltam que um longo tempo e uma alta temperatura de calcinação causam a cristalização da sílica amorfa, devido à presença de potássio e sódio nas cinzas, que acelera a fusão das partículas e a cristalização do cristobalita (DELLA; KÜHN; HOTZA, 2005).

Apesar de ser identificado pequeno teor de cristobalita, a CCAE apresenta-se predominantemente amorfa $(87,92 \%)$. Esse resultado pode ser justificado pela queima em temperatura relativamente baixa, pois conforme apontam alguns autores, a cristalização da sílica ocorre em temperatura superior a $800^{\circ} \mathrm{C}$ (GHORBANI et al., 2013; SANTANA COSTA; PARANHOS, 2018; SOLTANI et al., 2015).

O difratograma da cinza de pirólise é apresentado na Figura 03, onde não é visível nenhum pico cristalográfico, halo de amorfismo característico da sílica com pico centralizado na posição $2 \theta 22^{\circ}$. Confirmando que a amostra é $100 \%$ amorfa.

Da mesma forma que a cinza de engenho, atribui-se o alto grau de amorfismo às condições de queima, com temperatura controlada e queima completa.

É interessante ressaltar que apesar do alto grau de amorfismo, o índice de reação pozolânica das cinzas de engenho é bastante baixo, provavelmente em virtude de outros fatores, como heterogeneidade, granulometria e teor de material incombusto, como vem sendo relatado em muitos trabalhos ao longo dos anos (PINHEIRO, 2009; SANTOS; MOREIRA; SILVA JUNIOR, 2020).

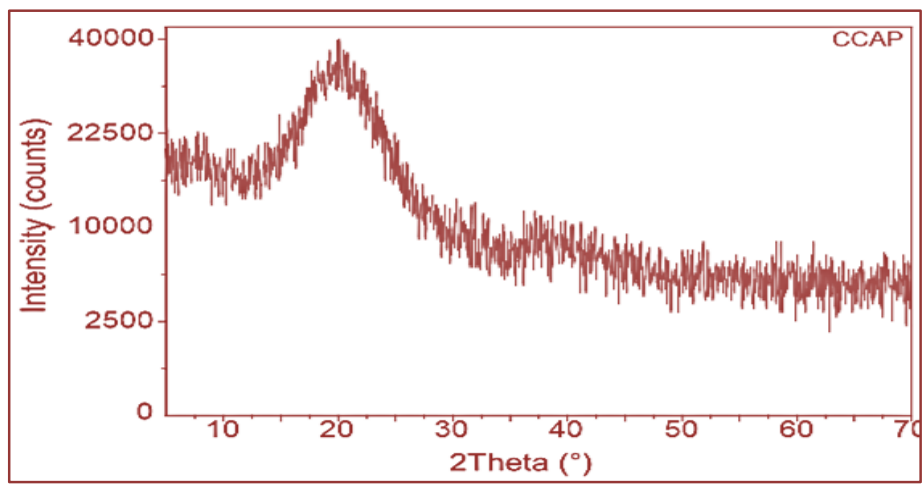


Figura 3 - Difratograma da amostra CCAP.

\section{CONSIDERAÇÕES FINAIS}

Os resultados apontam cinzas de pirólise $100 \%$ amorfas e índice de amorfismo superior a $87 \%$ nas cinzas de engenho. Esses resultados são considerados extremamente promissores, e permitem afirmar que ambas as cinzas apresentam potencial como precursores de sílica pelo processo sol-gel.

O método adotado para a determinação do teor de sílica amorfa nas cinzas mostrou-se bastante interessante, e uma alternativa aos métodos baseados na reação pozolânica, bastante usuais.

\section{REFERÊNCIAS}

[1] ADEBISI, J. A. et al. Green production of silica nanoparticles from maize stalk. Particulate Science and Technology, v. 0, n. 0, p. 1-9, 11 mar. 2019.

[2] ASIM, N. et al. Biomass and Industrial Wastes as Resource Materials for Aerogel Preparation: Opportunities, Challenges, and Research Directions. Industrial and Engineering Chemistry Research, v. 58, n. 38, p. 17621-17645, 2019.

[3] CORDEIRO, L. DE N. P.; MASUERO, Â. B.; DAL MOLIN, D. C. C. Análise do potencial pozolânico da cinza de casca de arroz (CCA) através da técnica de Refinamento de Rietveld. Matéria (Rio de Janeiro), v. 19, n. 2, p. 150-158, jun. 2014.

[4] DELLA, V. P.; KÜHN, I.; HOTZA, D. Reciclagem de Resíduos Agro-Industriais : Cinza de Casca de Arroz como Fonte Alternativa de Sílica. Cerâmica Industrial, v. 10, n. 2, p. 22-25, 2005.

[5] GHORBANI, F. et al. Preparation and characterization of highly pure silica from sedge as agricultural waste and its utilization in the synthesis of mesoporous silica MCM-41. Journal of the Taiwan Institute of Chemical Engineers, v. 44, n. 5, p. 821-828, set. 2013.

[6] GOMES, L. B. Estudo da formação do AlNb04 no sistema (x Al203 + 1-x Nb205) por técnicas de difração de Raios X e microscopia eletrônica em função da composição e temperatura de tratamento térmico. [s.l.] Universidade Federal do Rio Grande do Sul, 2016.

[7] ILER, R. K. The chemistry of silica: solubility, polymerization, colloid and surface properties, and biochemistry. Lavoisierfr, p. 892 pp, 1979.

[8] IMOISILI, P. E.; UKOBA, K. O.; JEN, T.-C. Green technology extraction and characterisation of silica nanoparticles from palm kernel shell ash via sol-gel. Journal of Materials Research and Technology, v. 9, n. 1, p. 307313, jan. 2020.

[9] IRIGON, P. I. DE; et al. Extraction of Silica from the residue of Thermoelectric Power Plants. Revista IberoAmericana de Ciências Ambientais, v. 10, n. 3, p. 103-113,17 jul. 2019.

[10] JOHAR, N.; AHMAD, I.; DUFRESNE, A. Extraction, preparation and characterization of cellulose fibres and nanocrystals from rice husk. Industrial Crops and Products, v. 37, n. 1, p. 93-99, maio 2012.

[11] PINHEIRO, D. G. L. Avaliação da atividade pozolânica em cinza de casca de arroz (CCA) com diferentes teores de sílica amorfa. [s.l.] Universidade de Brasília, 2009.

[12] SANTANA COSTA, J. A.; PARANHOS, C. M. Systematic evaluation of amorphous silica production from rice husk ashes. Journal of Cleaner Production, v. 192, n. 4, p. 688-697, ago. 2018.

[13] SANTOS, S. F. DOS; MOREIRA, L. D. A.; SILVA JUNIOR, L. A. Análise experimental da influência da cinza de casca de arroz sem queima controlada como adição mineral ao concreto. Research, Society and Development, v. 9, n. 1, p. 51911586, 1 jan. 2020.

[14] SHINDE, D. et al. Experimental and theoretical study of 1, 4-naphthoquinone based dye in dye-sensitized solar cells using ZnO photoanode. Materials Science-Poland, v. 35, n. 4, p. 746-754, 20 mar. 2018.

[15] SOLTANI, N. et al. Review on the physicochemical treatments of rice husk for production of advanced materials. Chemical Engineering Journal, v. 264, p. 899-935, mar. 2015. 


\section{Capítulo 11}

\section{Uso das cinzas de casca de arroz para obtenção de sílica pelo processo sol-gel}

\section{Mirian Dosolina Fuzinatto \\ Paula Irigon de Irigon \\ Pedro José Sanches Filho}

Resumo: A crescente preocupação com o meio ambiente vem mudando o comportamento da indústria e abrindo frente para o desenvolvimento de novos produtos a partir de resíduos potencialmente tóxicos ao meio ambiente. Neste contexto encontra-se a cinza de casca de arroz (CCA), protagonista deste projeto, reconhecidamente, um passivo ambiental do Rio Grande do Sul. As CCA são ricas em sílica, contendo de 90 a $97 \%$ em massa, deste composto. Neste projeto o objetivo é a extração de sílica de dois tipos de CCA: as cinzas provenientes de um Engenho da região de Pelotas (CCAC) e as cinzas de pirólise (CCAP) obtidas no IFSUL - campus Pelotas, através do método Sol-Gel. As CCAC e CCAP foram caracterizadas segundo a norma ASTM D1762, para determinar umidade, teor de voláteis, e cinzas. Na sequência foi realizada a extração da sílica pelo processo sol-gel seguindo o método de extração indicado na bibliografia. Foi testado também, uma adaptação do método com aumento superior a 3 vezes o volume de hidróxido de sódio. Os resultados apontam que ambos os resíduos são passíveis de extração de sílica pelo método sol-gel. 0 aumento de hidróxido de sódio promoveu o incremento do rendimento que chegou ao percentual de 93\%.

Palavras-Chave: Sustentabilidade, reaproveitamento, tratamento de resíduos sólidos. 


\section{INTRODUÇ̃̃O}

O arroz é um dos produtos agrícolas de maior produção e consumo no mundo. No mercado internacional, segundo dados da Agricultural Market Information System (FAO-AMIS, 2020) a produção mundial de arroz safra 2018/2019 foi de 506,31 milhões de toneladas. No Brasil a produção nacional da safra 2018/2019 foi de 10.483,6 mil toneladas e o Rio Grande do Sul (RS) foi responsável por 70,5\% (CONAB, 2020). A distribuição da produção gaúcha está demonstrada na figura 1. A cidade de Pelotas, que faz parte da regional Zona Sul, possui algumas das maiores Indústrias beneficiadoras de arroz do estado (IRGA, 2019).

Figura 3- Produção de arroz nas regiões do Rio Grande do Sul Safra 2018/2019 - IRGA-RS.

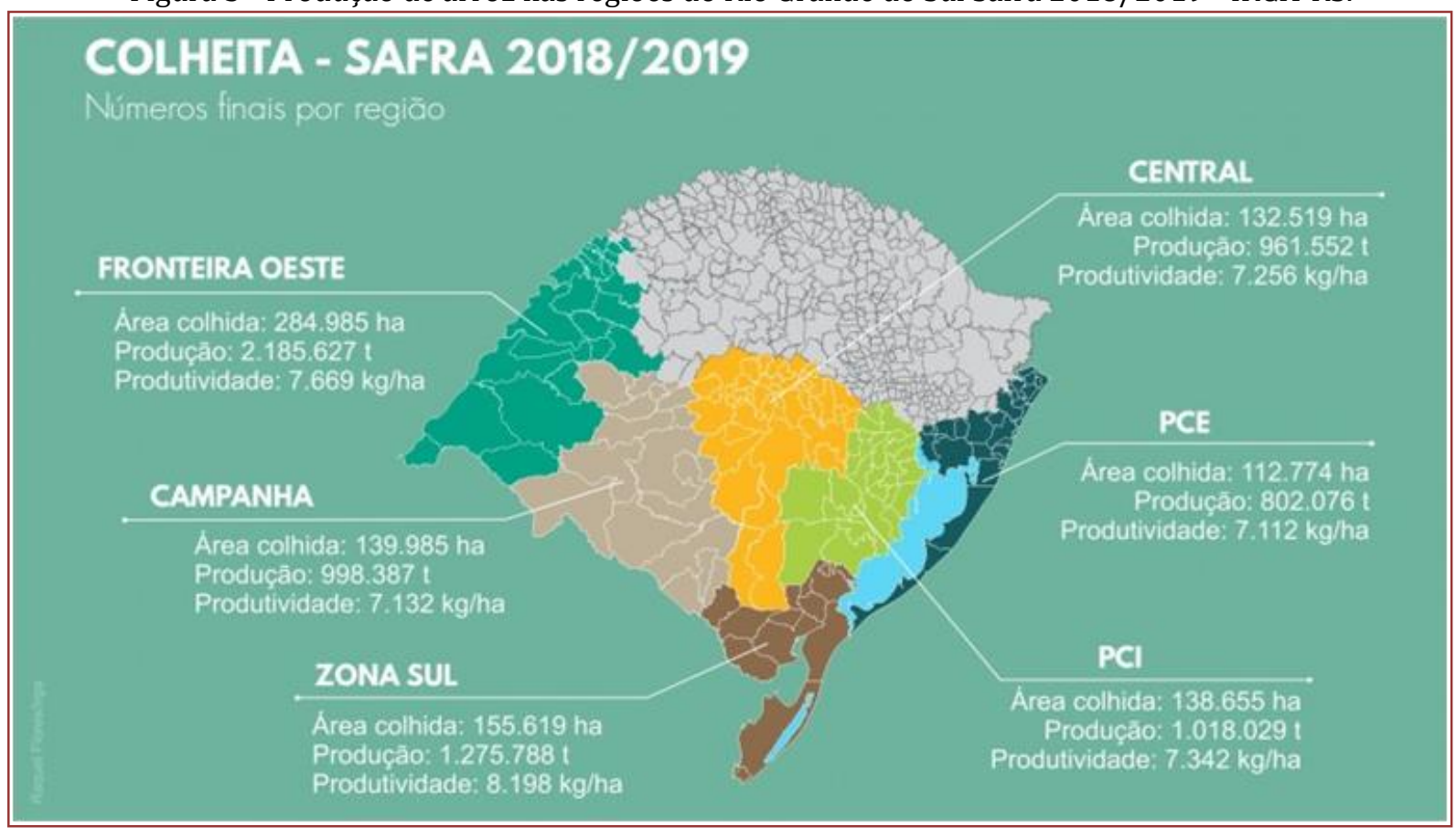

Visto a grande produção e beneficiamento de arroz na região, e considerando que aproximadamente $20 \%$ em massa do arroz é casca, este é um dos resíduos em maior abundância na Zona Sul do estado do Rio Grande do Sul. Para as arrozeiras a casca de arroz (CA) representa um grande problema ambiental e econômico. Uma alternativa para reduzir os impactos causados pela CA é a utilização desta como combustível para queima nas caldeiras, nos processos de geração de energia, segundo Huang et al.(2018) a CA possui poder calorífico de aproximadamente $16,25 \mathrm{MJ} / \mathrm{kg}$, o que proporciona a utilização como biomassa, através de processos termoquímicos (ADAMS et al., 2018).

Outra alternativa possível é a pirólise, que também é um processo termoquímico de conversão de biomassa, que está sendo muito estudado nas últimas décadas, principalmente pela facilidade de armazenamento e transporte do produto líquido (bio-óleo) que pode ser utilizado como combustível (DHYANI; BHASKAR, 2019). Os produtos obtidos por pirólise podem ser classificados em voláteis condensáveis, voláteis não condensáveis e "biochar".

Os voláteis condensáveis são aqueles produtos de pirólise que podem ser facilmente convertidos em líquido pela condensação (vapores), que é chamado de bio-óleo (BO) (BETEMPS et al., 2017; SILVEIRA, 2019). Os voláteis não condensáveis são os gases liberados pelo processo e, finalmente, o "biochar" é o produto sólido da queima da casca de arroz (cinza) em condições específicas, caracterizados pelo processo termoquímico controlado, como rampa de aquecimento, fluxo de gás, temperatura, granulometria e ausência de oxigênio.

O BO é uma mistura complexa de compostos aromáticos e alifáticos oxigenados que pode ser utilizado para obtenção de produtos químicos de valor agregado. E ele possui um importante conteúdo energético, podendo ser aproveitado em câmaras de combustão, motores a diesel e turbinas, entre outros (LORA, E.E ; VENTURINI, 2012). 
O produto gasoso também é combustível, composto basicamente por hidrogênio, monóxido de carbono, dióxido de carbono, metano e outros hidrocarbonetos gasosos com baixo peso molecular (ADHIKARI; NAM; CHAKRABORTY, 2018).

O biochar (sólido) é constituído essencialmente de carbono, oxigênio e rico em sílica, pode ser usado como fonte de energia em sistemas de combustão, sendo uma alternativa aos combustíveis sólidos, ou na remoção de contaminantes em função de suas propriedades adsorventes (GOSWAMI; KUMAR, 2018). Neste estudo o biochar é avaliado como material precursor para a obtenção de sílica.

As cinzas de casca de arroz estão associadas a efeitos cancerígenos, bioacumulativos, e a silicose, podendo resultar em problemas respiratórios, falta de ar, perda de apetite, síndrome de fadiga em humanos e também em animais (MOR et al., 2017; SOLTANI et al., 2015). Entre as opções de reutilização da CCAC e CCAP encontra-se a utilização como pozolana artificial, inclusive para produção de cimento. Porém, esta aplicação é limitada devido a quantidade de material incombusto das CCA . O que faz com que as indústrias tenham que pagar para a disposição destas cinzas em aterros, como um passivo ambiental.

Considerando o alto teor de sílica apresentado por ambos os resíduos, o reaproveitamento destes, como precursor para extração de sílica pelo método sol-gel representa tanto uma alternativa econômica como ambiental.

O sol-gel é um método físico-químico, baseado na capacidade de dissolução e precipitação da sílica (SOLTANI et al., 2015), que tem sido testado com diversos resíduos, com grande sucesso (EBISIKE; OKORONKWO; ALANEME, 2020; IRIGON et al., 2020; MOURHLY et al., 2019). As CCA possuem percentual de sílica em torno de 90 a 97\% em massa (FERNANDES et al., 2016). 0 método consiste em dispersar a CCA em uma solução alcalina de hidróxido de sódio, onde vai ocorrer a dissolução da sílica amorfa, através da conversão em silicato de sódio solúvel, conforme reação 1. Em uma segunda etapa, através da redução do pH com auxílio de um ácido, estes silicatos são convertidos e há a formação do ácido silícico, conforme reação 2. Os ácidos silícicos condensam e polimerizam ligados por ligações siloxanas, de acordo com a reação 3 (MOR et al., 2017).

$$
\begin{array}{lr}
\mathrm{SiO}_{2}+2 \mathrm{NaOH} \leftrightarrow \mathrm{Na}_{2} \mathrm{SiO}_{3} & \text { reação 1 } \\
\mathrm{Na}_{2} \mathrm{SiO}_{3}+2 \mathrm{HCl}+\mathrm{H}_{2} \mathrm{O} \leftrightarrow \mathrm{Si}(\mathrm{OH})_{4}+2 \mathrm{NaCl} & \text { reação 2 } \\
\equiv \mathrm{Si}-\mathrm{OH}+\equiv \mathrm{Si}-\mathrm{OH} \leftrightarrow \equiv \mathrm{Si}-\mathrm{O}-\mathrm{Si} \equiv+\mathrm{H}_{2} \mathrm{O} & \text { reação 3 }
\end{array}
$$

A sílica contida na casca do vegetal pode apresentar duas fases: parte amorfa e parte cristalina. 0 teor de sílica amorfa depende da temperatura e das condições de queima. Queima com temperaturas mais amenas produz sílica amorfa, enquanto temperaturas superiores a $800{ }^{\circ} \mathrm{C}$ produz sílica cristalina (SANTANA COSTA; PARANHOS, 2018). A sílica amorfa é uma forma alotrópica de silício que não possui orientação cristalográfica (CETEM/MCTIC, 2019), é mais reativa e pode ser extraída com o método sol-gel com maior facilidade.

Muitas investigações científicas foram publicadas, sobre as aplicações das cinzas de casca de arroz, algumas partiram da casca de arroz e outras direto das cinzas da casca de arroz, o assunto ainda está muito em alta conforme pode ser evidenciado pela pesquisa realizada na base de dados do Scopus, que está apresentada na figura 2. 
Figura 2: Número de publicações envolvendo as palavras: cinzas de casca de arroz e sol-gel.

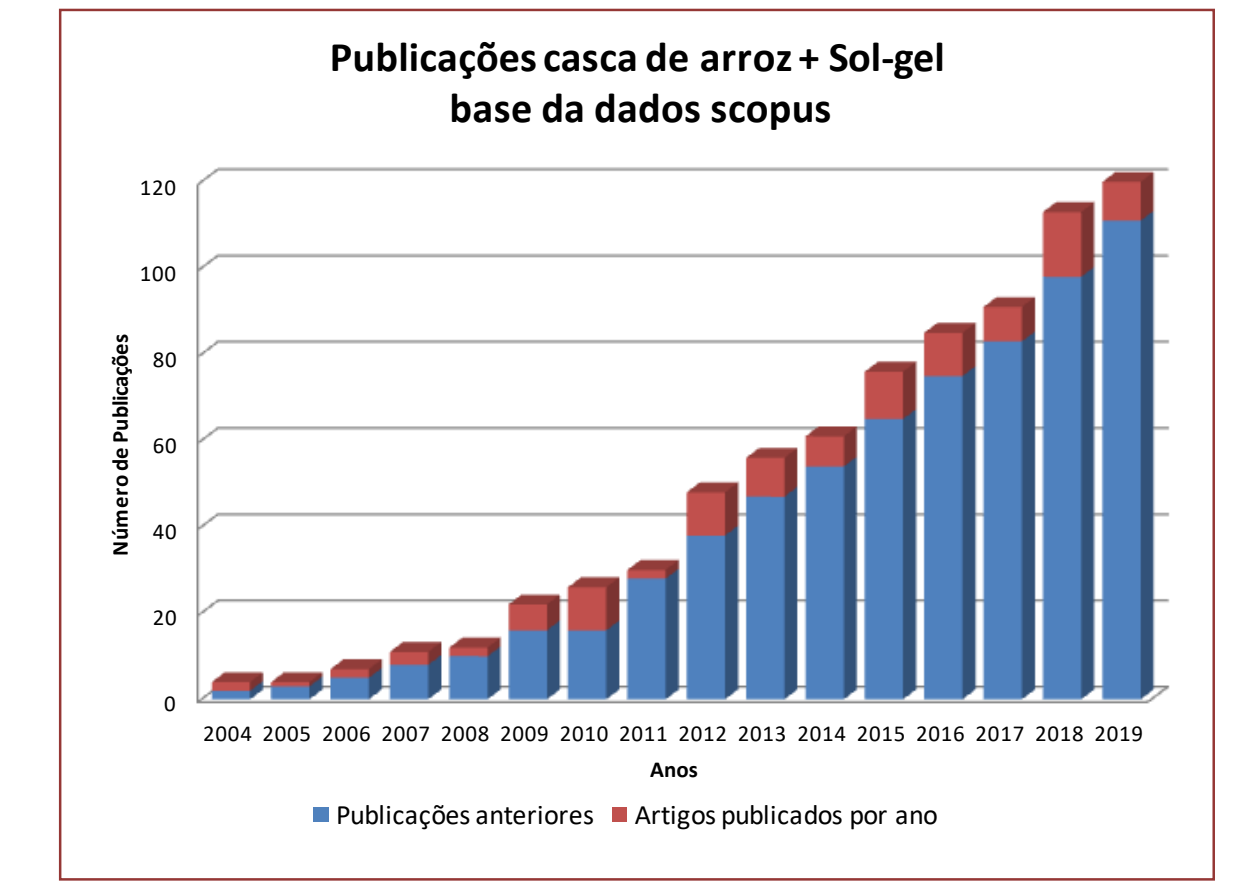

https://www.sciencedirect.com/search/advanced?qs=rice\%20husk\%20ash. Site visitado em 28/10/2019.

As propriedades da sílica obtida das cinzas de casca de arroz, tais como pureza, microestrutura, cristalinidade, alta resistência química, térmica, e mecânica, bem como alta refratariedade, possibilitam um espectro de aplicações muito vasto. Na tabela 1 estão demonstrados algumas das principais aplicações da sílica.

Tabela 1 Algumas aplicações da sílica das cinzas de casca de arroz

\begin{tabular}{|c|c|}
\hline Referência & Aplicação \\
\hline $\begin{array}{l}\text { (KAUR; REDDY; PANDEY, 2020);(CHEN } \\
\text { et al., 2017) }\end{array}$ & Vidro bioativo \\
\hline (HU; HE; ZHANG, 2020) & Material base de cimento \\
\hline (NASSAR; AHMED; RAYA, 2019) & Capacidade de adsorção para a remoção do antibiótico ciprofloxacino \\
\hline (ALMEIDA et al., 2019) & Pigmento inorgânico preto \\
\hline $\begin{array}{l}\text { (BOONMEE; SABSIRIROHT; } \\
\text { JARUKUMJORN, 2019) }\end{array}$ & Filler em borracha natural \\
\hline (ABBAS et al., 2019) & $\begin{array}{l}\text { Agregado substituto para Compósitos à base de cimento e com } \\
\text { isolamento térmico }\end{array}$ \\
\hline (PRESTIANGGI et al., 2019) & $\begin{array}{l}\text { Síntese de Santa Bárbara Amorfa-15 (SBA-15) a partir de cinza de } \\
\text { casca de arroz }\end{array}$ \\
\hline (ZHANG; LI; BAO, 2019) & Síntese de zeólita ZSM-5 a partir de cinza de casca de arroz \\
\hline
\end{tabular}

Contudo, o presente trabalho consiste na avaliação da viabilidade de aplicar o método sol-gel na extração de sílica a partir de resíduos locais, ainda sem aproveitamento adequado, obtidos em condições de queima bastante distintas: queima por pirólise (CCAP) e queima por combustão na fornalha de caldeira (CCAC).

\section{METODOLOGIA}

Este estudo está sendo desenvolvido nas dependências do Instituto Federal de Educação, Ciência e Tecnologia Sul-Rio-Grandense (IFSUL)- Campus Pelotas, no laboratório de Contaminantes Ambientais (LACA), no laboratório Análise de Combustíveis 2 (LACOM 2) e no Laboratório de Processos da Engenharia Química. 
O estudo consiste em realizar a extração da sílica de duas amostras obtidas em condições de queima bastante distintas: queima por pirólise (CCAP) e queima por combustão na fornalha da caldeira da Indústria de Beneficiamento de Arroz e seus derivados (CCAC).

\subsection{OBTENÇÃO DAS CINZAS DA CASCA DE ARROZ}

A CCAC foi fornecida por uma Indústria arrozeira da cidade de Capão do Leão, RS, obtida da queima da casca de arroz por combustão, na fornalha da caldeira do engenho, com sistema de grelha móvel e temperaturas de operação na faixa de $800^{\circ} \mathrm{C}$.

A CCAP foi produzida em planta piloto instalada no IFSUL - campus Pelotas.

\subsubsection{PROCESSO DE PIRÓLISE}

A pirólise da CA foi realizada em escala semi-industrial na planta piloto SIVOMO-250 (Sistema de Volatilização de Materiais Orgânicos), representada Figura 3, composta por um reator de aço inox, um condensador, dois coletores de BO e uma saída para gases. 0 sistema contém ainda cinco termopares (T1, T2, T3, T4 e T5), quatro registrando a temperatura no interior do reator e um na saída do condensador, um medidor de pressão, um conjunto de resistências para o aquecimento do reator e um controlador de temperatura (marca NOVUS, modelo N480D) para as resistências. Para o registro das temperaturas, a planta utiliza um sistema de aquisição de dados de 8 canais de entrada com software de monitoramento on-line e coleta de dados. Utilizou-se o software Field Chart Lite, da empresa NOVUS, para este fim.

0 processo foi realizado em leito fixo e em batelada, com a massa de $150 \mathrm{~g}$ de casca de arroz seca, com granulometria entre 24 e 16 mesh, adicionada diretamente ao reator no início do experimento. Como gás de arraste é utilizado o nitrogênio e o ajuste da vazão do gás é realizada utilizando um rotâmetro. Para condensação dos compostos voláteis gerados, o condensador é mantido em temperatura inferior a $10{ }^{\circ} \mathrm{C}$ através da circulação de água em sistema fechado e contracorrente. Compostos não condensados são considerados como fração gasosa. Esta fração é borbulhada em Diclorometano( DCM) a baixa temperatura visando a captura de voláteis solúveis neste solvente e que não condensaram durante o processo.

A temperatura utilizada para os experimentos foi de $600^{\circ} \mathrm{C}$ e taxa média de aquecimento de $25^{\circ} \mathrm{C} \min ^{-1}$. Esta temperatura foi escolhida considerando a análise termogravimétrica (TGA) da casca de arroz e limitações do processo.

Figura 3 SIVOMO com seus componentes identificados

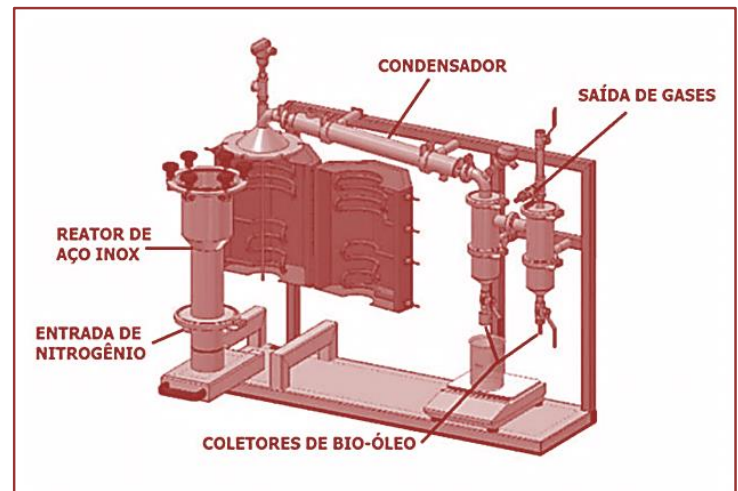

. Fonte: Silveira, 2019.

\subsection{CARACTERIZAÇÃO DAS (CCAC) E DAS (CCAP)}

As CCAC e as CCAP foram preparadas e analisadas em triplicata, segundo a norma ASTM D1762 (ASTM, 2007). A amostra foi moída até passante em peneira ABNT de malha igual a \# 20 mesh, em seguida armazenada para as análises. A sequência de análises foi realizada conforme figura 4. 
Figura 4 Sequência de analises conforme norma ASTM D1762 (2007).

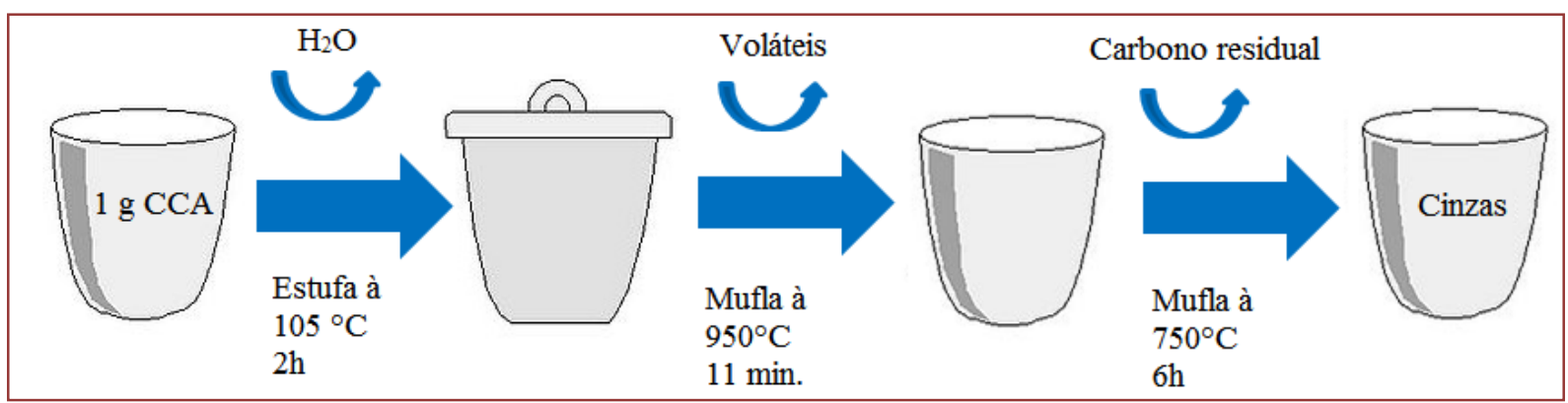

A amostra foi seca em estufa a $105{ }^{\circ} \mathrm{C}$ e após peso constante foi transferida para a Mufla para determinação do material volátil, seguindo os seguintes passos: com a porta do forno aberta, deixar o cadinho com tampa por 2 minutos na parte externa da Mufla, em temperatura de aproximadamente 300 ${ }^{\circ} \mathrm{C}$ e depois, por 3 minutos, na borda da Mufla em temperatura de aproximadamente $500{ }^{\circ} \mathrm{C}$. Em seguida, mover o cadinho com tampa para a parte traseira da Mufla por 6 minutos e com a porta fechada, por fim a amostra foi esfriada no dessecador por $1 \mathrm{~h}$ e em seguida pesada. As cinzas foram obtidas do resíduo da determinação do material volátil, a $750^{\circ} \mathrm{C}$ por $6 \mathrm{~h}$ e até peso constante. Para a determinação do teor de Carbono fixo foi considerado o carbono que não volatiliza, obtido matematicamente, subtraindo de 100 os teores de umidade, materiais voláteis e cinzas das amostras, conforme Fernandes (2015).

\subsection{METODOLOGIA DE EXTRAÇÃo DA SÍLICA DAS (CCAC) E (CCAP)}

O processo de extração da sílica foi realizado por dois procedimentos, o primeiro seguindo o método de Kalapathy et.al. (2001), e o segundo uma adaptação do método anterior, porém alterando o volume de $\mathrm{NaOH}$ na extração, de $60 \mathrm{ml}$ para $200 \mathrm{ml}$, conforme, figura 5.

Todas as amostras sofreram um pré-tratamento de lavagem ácida, com $\mathrm{HCl} 1 \mathrm{M}$ até pH 5, em agitação constante por $2 \mathrm{~h}$ a $80^{\circ} \mathrm{C}$. Filtradas em filtro quantitativo onde o líquido foi descartado e o retido foi seco a $80^{\circ} \mathrm{C}$ por $24 \mathrm{~h}$.

As condições de extração aplicadas no primeiro método foram: $60 \mathrm{ml}$ de $\mathrm{NaOH} 1 \mathrm{M}$, por 1 hora à $90^{\circ} \mathrm{C}$, com agitação constante, nas amostras CCAP 1 e CCAC 1.

No segundo método as condições de extração aplicadas nas amostras CCAC 2 foram: $200 \mathrm{ml}$ de NaOH 1M, por 1 hora a $90^{\circ} \mathrm{C}$ com agitação constante.

Após a extração foi realizada a filtragem em papel filtro quantitativo, o resíduo carbônico foi reservado para posterior análise e o filtrado foi para a etapa de redução de $\mathrm{pH}$ com $\mathrm{HCl} 1 \mathrm{M}$.

Todas as amostras foram tituladas com HCL $1 \mathrm{M}$ até pH 7, envelhecidas por 18h, lavadas com água deionizada e centrifugadas 15 minutos à $2500 \mathrm{rpm}$, até elimina ção do $\mathrm{NaCl}$, com ausência de turvação pela adição de Nitrato de Prata. Em seguida foram secas em estufa à $80^{\circ} \mathrm{C}$, por $24 \mathrm{~h}$, obtendo-se a sílica xerogel.

A determinação do rendimento foi calculada a partir do teor de cinzas das amostras obtidos na caracterização imediata, como segue:

$$
\% \eta=\left(\mathrm{SiO}_{2} /(\mathrm{TC} \times \mathrm{MO})\right) * 100
$$

Onde: $\mathrm{SiO}_{2}=$ Peso final da sílica Xerogel, em gramas; $\mathrm{MO}=$ massa de amostra inicial, em gramas ; e TC = Teor de cinzas, em fração mássica. 
Figura 5 - Diagrama esquemático do processo sol-gel para obtenção de sílica das CCA

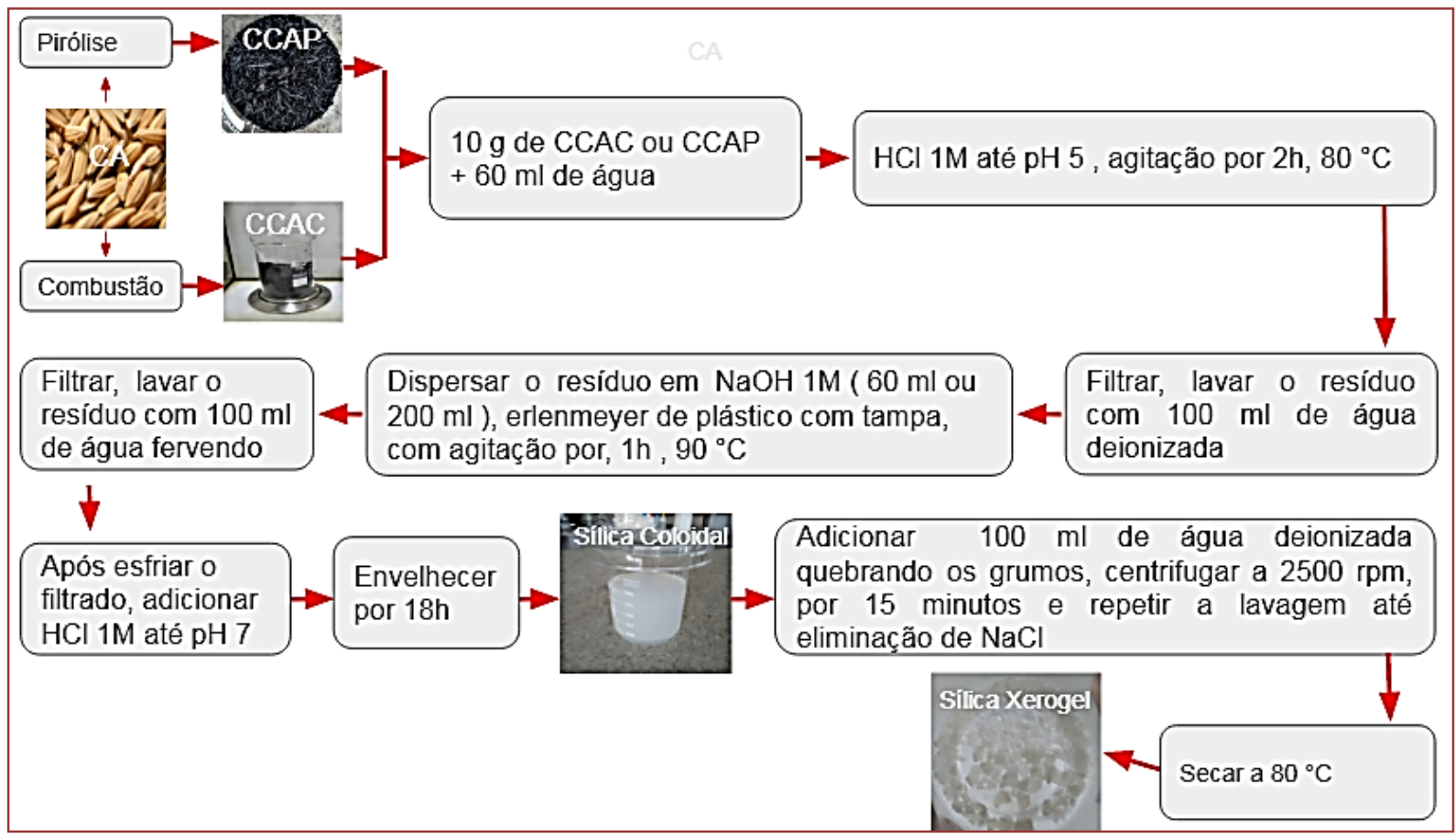

\section{RESULTADOS E DISCUSSÕES}

\subsection{CARACTERIZAÇÃO DAS (CCAC) E DAS (CCAP)}

A tabela 2 apresenta os resultados da caracterização pela análise imediata quanto a \% de umidade, \% de material volátil, \% de cinzas e o cálculo do carbono fixo.

Tabela 2 - Características gerais das cinzas da casca de arroz

\begin{tabular}{|ccc|}
\hline Análise Imediata ( \% peso) & CCAC & CCAP \\
\hline Umidade & $4,9 \pm 0,1$ & $2,2 \pm 0,03$ \\
Material Volátil & $7,9 \pm 0,4$ & $4,0 \pm 0,4$ \\
Carbono Fixo * & 42,0 & 5,6 \\
Cinzas & $45,2 \pm 0,2$ & $88,2 \pm 0,1$ \\
\hline${ }^{*}$ O Carbono fixo é obtido matematicamente: 100 menos a \% umidade, \% Material Volátil e \% cinzas \\
\hline
\end{tabular}

Pelos dados da tabela 2, podemos verificar que as CCAC possuem ainda muito material incombusto (42\%), já na CCAP é bem menor, apesar de apresentar ainda uma coloração escura. Isso pode ser explicado baseado nos estudos de Krishnarao et al., (2001) que atribui ao óxido de potássio como um dos principais responsáveis pela coloração escura das cinzas de casca de arroz. No processo de queima não há tempo suficiente para todo o carbono ser liberado antes que a temperatura alcance uma temperatura superior a $347^{\circ} \mathrm{C}$, que é a temperatura de decomposição do $\mathrm{K}_{2} \mathrm{O}$ em potássio, com a qual provoca o derretimento da sílica e com isso parte deste carbono fica retido nos poros das cinzas da casca de arroz. Para que este óxido seja removido os autores indicam um tratamento inicial do resíduo com ácido (lavagem ácida). 
Em relação ao CCAC conforme já descrito, ela é obtida por combustão na fornalha de caldeira, com sistema de grelha móvel, segundo estudos de Fernandes et al.,(2016) o sistema de grelha móvel comparado com a tecnologia do leito fluidizado possui menor eficiência no processo de queima, a vantagem do leito fluidizado é explicada por haver menores gradientes de temperatura ou pontos de estagnação dentro do sistema, a fluidização proporciona excelentes condições de contato entre a fase sólida e o fluído, com tempos de permanência mais longos das partículas dentro do reator, esta técnica possibilita baixos níveis de carbono nas CCA.

\subsection{RENDIMENTO DA EXTRAÇÃO DA SÍLICA DAS (CCAC) E DAS (CCAP)}

Os resultados dos rendimentos da sílica estão listados na tabela 3, onde pode ser verificado que com o aumento da adição de $\mathrm{NaOH} 1 \mathrm{M}$ foi possível incrementar o rendimento, obtendo valores muito significativos. Análises de FRX e de EDX devem ser realizadas para complementar o trabalho e indicar a pureza desta sílica.

0 rendimento da extração conforme literatura está diretamente ligado a dosagem de $\mathrm{NaOH}$ utilizada, a temperatura e o tempo da reação de formação do silicato de sódio. No trabalho atual, foi fixada a temperatura e o tempo e ajustado a dosagem de $\mathrm{NaOH}$, foi mantida a concentração de $1 \mathrm{M}$, e aumentado o volume de 60ml para $200 \mathrm{ml}$ (HESSIEN et al., 2009; KALAPATHY; PROCTOR; SHULTZ, 2001; SANTANA COSTA; PARANHOS, 2018). A definição da dosagem foi calculada por estequiometria, considerando excesso de reagente $(\mathrm{NaOH})$. Os resultados até o momento comprovam o aumento do rendimento em função do aumento de reagente $\mathrm{NaOH}$.

Tabela 3 - Rendimento da Extração de Sílica

\begin{tabular}{|ccc|}
\hline Produto & Extração & Rendimento da Sílica (\%) \\
\hline CCAP 1 & $60 \mathrm{ml}$ de NaOH $1 \mathrm{M}, 1 \mathrm{~h}, 90^{\circ} \mathrm{C}$ com agitação & $58,36 \pm 0,82$ \\
$\mathrm{CCAC} 1$ & $60 \mathrm{ml}$ de NaOH $1 \mathrm{M}, 1 \mathrm{~h}, 90^{\circ} \mathrm{C}$ com agitação & $60,89 \pm 0,78$ \\
$\mathrm{CCAC} 2$ & $200 \mathrm{ml}$ de $\mathrm{NaOH} 1 \mathrm{M}, 1 \mathrm{~h}, 90^{\circ} \mathrm{C} \mathrm{com}$ agitação & $92,96 \pm 0,84$ \\
\hline
\end{tabular}

\section{CONSIDERAÇÕES FINAIS}

Através deste estudo foi possível confirmar a viabilidade da extração de sílica de ambos as cinzas estudadas, não houve diferença significativa entre os rendimentos da CCAP e CCAC. $\mathrm{O}$ aumento da quantidade de $\mathrm{NaOH}$ com a CCAC levou o aumento do rendimento, o que comprova a necessidade de adequação do processo as características das cinzas avaliadas, indicado pela melhora do rendimento.

Com base nos dados apresentados, foi possível observar que é possível conseguir um rendimento significativo na produção de sílica a partir de cinzas de casca de arroz, chegando a um valor de $93 \%$ de rendimento. Os resultados aqui apresentados constituem o primeiro passo de uma pesquisa promissora. Na sequência devem ser analisadas condições ideais de extração, bem como a caracterização da sílica produzida.

\section{REFERENCIAS}

[1] ABBAS, N. et al. Silica aerogel derived from rice husk: an aggregate replacer for lightweight and thermally insulating cement-based composites. Construction and Building Materials, v. 195, p. 312-322, 20 jan. 2019.

[2] ADAMS, P. et al. (EDS.). Biomass Conversion Technologies. In: Greenhouse Gas Balances of Bioenergy Systems. United Kingdom: Elsevier Inc., 2018. p. 107-139.

[3] ADHIKARI, S.; NAM, H.; CHAKRABORTY, J. P. Conversion of solid wastes to fuels and chemicals through pyrolysis. In: Waste Biorefinery: Potential and Perspectives. [s.l.] Elsevier B.V., 2018. p. 239-263.

[4] ALMEIDA, S. R. et al. Black SiO 2 nanoparticles obtained by pyrolysis of rice husk. Dyes and Pigments, v. 164, p. 272-278, 1 maio 2019.

[5] ASTM. Standard Test Method for Chemical Analysis of Wood Charcoal - Designation: D 1762 - 84 (Reapproved 2007). Annual Book of ASTM Standards, v. 84, n. 2, p. 292-293, 2007.

[6] BETEMPS, G. R. et al. Chromatographic characterization of bio-oil generated from rapid pyrolysis 
of rice husk in stainless steel reactor. Microchemical Journal, v. 134, p. 218-223, 2017.

[7] BOONMEE, A.; SABSIRIROHT, P.; JARUKUMJORN, K. Preparation and characterization of rice husk ash for using as a filler in natural rubber. Materials Today: Proceedings. Anais...Elsevier Ltd, 1 jan. 2019

[8] CETEM/MCTIC. Silício grau solar: uma revisão das tecnologias de produção. Rio de Janeiro: Silvia Cristina Alves França, 2019.

[9] CHEN, S. Y. et al. Preparation and characterization of mesoporous bioactive glass from agricultural waste rice husk for targeted anticancer drug delivery. Ceramics International, v. 43, n. 2, p. 2239-2245, 1 fev. 2017.

[10] CONAB. Conab - Série Histórica das Safras. Disponível em: <https://www.conab.gov.br/infoagro/safras/serie-historica-das-safras?start=10>. Acesso em: 27 nov. 2020.

[11] DHYANI, V.; BHASKAR, T. Pyrolysis of biomass. Biomass, Biofuels, Biochemicals: Biofuels: Alternative Feedstocks and Conversion Processes for the Production of Liquid and Gaseous Biofuels, p. 217-244, 2019.

[12] EBISIKE, K.; OKORONKWO, A. E.; ALANEME, K. K. Synthesis and characterization of Chitosansilica hybrid aerogel using sol-gel method. Journal of King Saud University - Science, v. 32, n. 1, p. 550-554, 2020.

[13] FAO-AMIS. Agricultural Market Information System (AMIS), 2020. Disponível em: $<$ https://app.amis-outlook.org/\#/market-database/supply-and-demand-overview>. Acesso em: 27 nov. 2020

[14] FERNANDES, I. J. et al. Characterization of rice husk ash produced using different biomass combustion techniques for energy. Fuel, v. 165, p. 351-359, 2016.

[15] GOSWAMI, R.; KUMAR, M. Removal of fluoride from aqueous solution using nanoscale rice husk biochar. Groundwater for Sustainable Development, v. 7, p. 446-451, 1 set. 2018.

[16] HESSIEN, M. M. et al. Controlling the synthesis conditions for silica nanosphere from semi-burned rice straw. Materials Science and Engineering B: Solid-State Materials for Advanced Technology, v. 162, n. 1, p. 14-21, 2009.

[17] HU, L.; HE, Z.; ZHANG, S. Sustainable use of rice husk ash in cement-based materials: Environmental evaluation and performance improvement. Journal of Cleaner Production, v. 264, p. 121744, 10 ago. 2020.

[18] HUANG, Y. F.; LO, S. L. Utilization of rice hull and straw. [s.l.] AACCI. Published by Elsevier Inc. in cooperation with AACC International, 2018.

[19] IRGA. Irga divulga lista das 50 maiores beneficiadoras de arroz do RS - IRGA. Disponível em: $<$ https://irga.rs.gov.br/irga-divulga-lista-das-50-maiores-beneficiadoras-de-arroz-do-rs>. Acesso em: 27 nov. 2020.

[20] IRIGON, P. I. DE et al. Extraction of Silica from the residue of Thermoelectric Power Plants. Revista Ibero-Americana de Ciências Ambientais, v. 10, n. 3, p. 103-113, 2020.

[21] KALAPATHY, U.; PROCTOR, A.; SHULTZ, J. A simple method for production of pure silica from rice hull ash. Fuel and Energy Abstracts, v. 42, n. 1, p. 45, 2001.

[22] KAUR, D.; REDDY, M. S.; PANDEY, O. P. Synthesis, characterization, drug loading and in-vitro bioactivity studies of rice husk derived SiO2-P2O5-MgO-CaO-SrO bio-active glasses. Journal of Drug Delivery Science and Technology, p. 102154, 15 out. 2020.

[23] KRISHNARAO, R.V. * J. SUBRAHMANYAM, T. J. K. On the Characteristics of Clusters Produced in $400 \mathrm{GeV}$ p-N Interactions. Journal of the European Ceramic Society, v. 21, p. 99-104, 2001.

[24] LORA, E.E ; VENTURINI, O. J. Biocombustíveis. 1, volume. ed. Rio de Janeiro: Interciência, 2012.

[25] MOR, S. et al. Nanosilica extraction from processed agricultural residue using green technology. Journal of Cleaner Production, v. 143, p. 1284-1290, 2017.

[26] MOURHLY, A. et al. Highly efficient production of mesoporous nano-silica from unconventional resource: Process optimization using a Central Composite Design. Microchemical Journal, v. 145, n. July 2018, p. 139-145, 2019. 
[27] NASSAR, M. Y.; AHMED, I. S.; RAYA, M. A. A facile and tunable approach for synthesis of pure silica nanostructures from rice husk for the removal of ciprofloxacin drug from polluted aqueous solutions. Journal of Molecular Liquids, v. 282, p. 251-263, 15 maio 2019.

[28] PRESTIANGGI, Y. et al. Adsorption of toluene and xylene from aqueous solution on SBA-15 from rice husk. Journal of Physics: Conference Series, v. 1277, n. 1, 2019.

[29] SANTANA COSTA, J. A.; PARANHOS, C. M. Systematic evaluation of amorphous silica production from rice husk ashes. Journal of Cleaner Production, v. 192, p. 688-697, 2018.

[30] SILVEIRA, L. A. Estudo de parâmetros operacionais do processo de pirólise da casca de arroz e caracterização do bio-óleo obtido. Trabalho de Conclusão de Curso (Curso Superior de Engenharia Química)—Pelotas: Instituto Federal Sul-Rio-Grandense - Campus Pelotas, 2019.

[31] SOLTANI, N. et al. Review on the physicochemical treatments of rice husk for production of advanced materials. Chemical Engineering Journal, v. 264, p. 899-935, 2015.

[32] ZHANG, C.; LI, S.; BAO, S. Sustainable Synthesis of ZSM-5 Zeolite from Rice Husk Ash Without Addition of Solvents. Waste and Biomass Valorization, v. 10, n. 10, p. 2825-2835, 2019. 


\section{Capitulo 12}

\section{Tratamento de efluentes das indústrias têxteis: Revisão de literatura}

\section{Gabriel Oliveira Roque}

Yuri Fernando Dubbern

Victor José dos Santos Baldan

Bárbara Maria Borges Ribeiro

Resumo: Os residuos da contrução civil e a coloração de tecidos é um dos grandes causadores de contaminação em corpos hídricos e do meio ambiente, por conta disso há muita preocupação em relação ao tratamento dos efluentes utilizados na tinturaria das indústrias têxteis. 0 objetivo deste trabalho foi realizar uma revisão de literatura sobre os métodos de tratamento de efluentes das indústrias têxteis e uso de RCC's. Para isto, utilizam-se a plataforma Google Acadêmico e Scielo para fundamentação teórica, na qual se explica os principais métodos e seu custo-benefício de implementação. Verificou-se que os processos de adsorção aplicados juntamente ou não de outros mecanismos de tratamento se tornam eficazes e rentáveis, obtendo um efluente tratado de boa qualidade e com um custo não elevado.

Palavras-chave: Efluentes; indústrias têxteis; tratamento; adsorção. 


\section{INTRODUÇ̃̃O}

Os efluentes líquidos gerados pela atividade das indústrias têxteis causam severos impactos no meio ambiente, especialmente nos corpos hídricos por descarte de efluentes que possuem elevadas concentrações de compostos químicos e orgânicos. Dentre os principais compostos dos efluentes gerados por esta indústria têm-se os corantes que são altamente tóxicos e de difícil degradação. (ALMEIDA e CORSO, 2014).

Para lidar com este problema, atualmente, existe uma grande variedade de métodos de tratamentos de efluente, cada qual com seu rendimento, particularidade e custo de operação, dentre eles têm-se: adsorção, oxidação e bio-degradação. Normalmente, o tratamento de efluentes possui uma ou mais etapas como: coagulação/floculação seguida por filtros de carvão ativado ou resinas adsorventes, ou combinações destes com processos biológicos e osmose reversa, respeitando-se as especificações desejadas em cada processo. (ALMEIDA e CORSO, 2014).

Logo, objetiva-se com este estudo apresentar e comparar os métodos de tratamento de efluentes de indústria têxteis, e avaliar qual processo tem melhor custo-benefício de operação, custo e implementação. Neste sentido, o presente trabalho mostra-se importante e propõe métodos utilizados para reduzir o impacto ambiental causado pelos efluentes avaliados e os resíduos da construção civil que podem ser usado como materiais adsorventes nos filtros utilizados.

\section{METODOLOGIA}

Foi realizada a revisão de literatura para comparação entre os métodos de tratamentos de efluentes provenientes de indústrias têxteis. Para isto, utilizaram-se base de dados Google Acadêmico e Scielo, considerando os trabalhos publicados no período de 20 anos (de 2000 a 2020). Para a busca consideraram-se as palavras-chaves: indústria têxtil, corante, tratamento de efluentes, textile industry, dye e waste treatment.

\section{RESULTADOS E DISCUSSÃO}

Os principais efluentes da indústria têxtil são os corantes que podem ser classificados em corantes ácidos, azóicos, branqueadores, a cuba, diretos, dispersivos, de enxofre, pré-metalizados e reativos. (GUARATINI e ZANONI, 2000). Devido à sua estrutura química, os corantes são moléculas de difícil degradação e podem possuir compostos inibidores de micro-organismos diminuindo ainda mais a degradação natural no meio ambiente. (ALMEIDA e CORSO, 2014).

De acordo com Almeida e Corso (2014), quando a degradação é realizada de forma incompleta, são gerados subprodutos, ou seja, compostos químicos altamente tóxicos que agravam a poluição ao homem e nos corpos hídricos, motivo este que gera interesse à comunidade cientifica e aos órgãos ambientais.Sendo assim, a preservação do meio ambiente é uma questão de grande preocupação social e legislativa que promove a busca por abordagens e projetos para o descarte de poluentes biodegradáveis e tóxicos. Não existe um sistema geral de tratamento destes, mas há muitas formas de tratamento, nenhuma totalmente eficaz e algumas precisam de associação de técnicas que elevam o custo, tornando-se inviável em alguns casos. (ALMEIDA e CORSO, 2014).

Dentre os métodos de tratamento de efluentes provenientes de indústrias têxteis abordados neste trabalho estão: adsorção, oxidação e biodegradação, que são os mais utilizados. A adsorção é um método de remoção de poluentes em fluidos, passa-se o fluido contaminado por um leito, onde se encontra material adsorvente. Existem diversos materiais que podem ser utilizados como adsorventes, mas, na maioria dos casos, utiliza-se carvão ativado. Neste processo, remove- se a maior parte dos poluentes existentes na água em tratamento, o composto retirado é chamado adsorbato. (NASCIMENTO et al, 2014). A adsorção é considerada um tratamento físico-químico, pois retém os poluentes por quimissorção, onde há ligação entre as moléculas do adsorvente e do adsorbato, ou então, por fisissorção, retendo o adsorbato de forma mecânica, tendo interação baixa entre as moléculas do adsorvente do adsorbato, isso vai depender dos materiais envolvidos, dos componentes a serem retirados do fluido e do adsorvente utilizado. (NASCIMENTO et al, 2014). 
A biodegradação é outra técnica utilizada no tratamento de efluentes. Neste processo, são empregados micro-organismos, comumente fungos e bactérias, com capacidade de converter moléculas químicas complexas em moléculas mais simples, degradando assim as moléculas poluentes. (ALMEIDA e CORSO, 2014)

Já o processo oxidativo se caracteriza pela produção de radicais hidroxilas $(\cdot \mathrm{OH})$ que mineraliza qualquer molécula orgânica gerando água, dióxido de carbono $\left(\mathrm{CO}_{2}\right)$ e íons orgânicos com baixa toxicidade. (MALDONADO et al., 2007). Afirma Saratale et al. (2011), que o método de oxidação eletroquímica usa o elétron e catalisadores que geram subprodutos inofensivos, mas o alto custo de implementação dificulta a operação em escala industrial.

Dentre os principais tipos de tratamento, têm-se combinações e subdivisões como, por exemplo, membranas, coagulação/floculação, radiação ultravioleta, fotoquímica, dentre outros (SILVA, 2013). Verifica-se, no Quadro 1, a comparação entre os métodos, considerando-se a qualidade do efluente tratado e o custo operacional.

Quadro 1: Comparativo de alguns métodos de tratamentos de efluentes de indústrias têxteis

\begin{tabular}{|l|c|c|}
\multicolumn{1}{|c}{ Processos } & $\begin{array}{c}\text { Qualidade do } \\
\text { efluente } \\
\text { tratado }\end{array}$ & Custo \\
\hline Coagulação/ floculação+filtro de carvão ativado & Boa & Muito elevado \\
\hline Coagulação/ floculação+filtro+resinas adsorventes & Boa & Muito elevado \\
\hline Processo biológico+coagulação/floculação+filtração & Boa/ Muito boa & Elevado \\
\hline Processo biológico+coagulação/ floculação+resinas iônicas líquidas+filtro & Muito boa & Elevado \\
\hline Processo biológico+coagulação/ floculação+osmose reversa & Muito boa & Muito elevado \\
\hline Processo biológico+filtro+resinas adsorventes & Muito boa & Elevado \\
\hline Processo biológico+filtro+carvão ativado granular & Muito boa & Elevado \\
\hline Processo biológico de lodos ativados+carvão ativado em pó & Muito boa & Moderado \\
\hline
\end{tabular}

Fonte: adaptação de Leão et al. (2002)

Observa-se, no Quadro 1, a existência de diversos métodos de tratamento de efluentes de indústria têxtil, estabelece-se um comparativo referente à qualidade do tratamento e ao custo de funcionamento de cada um.

0 processo de coagulação ou floculação, de acordo com este quadro, demonstra um custo elevado de implementação que reforça a importância de pesquisa nesta área para melhorar sua viabilidade ecômica. Os filtros são meios importantes e de fácil implementação, no qual o material adsorvente modifica seu custo, onde, por exemplo, resinas adsorventes têm um maior custo que o carvão ativado.

No que diz respeito ao tratamento por processo biológico, percebe-se, também, que possui um custo muito elevado por necessitar de técnicas e estruturas muito específicas em meio a processos concomitantes como osmose reversa e uso específico de resinas iônicas, lodos ativados e filtros, sendo de suma importância nesta área que gera a necessidade de capacitação técnica.

De acordo com a leitura e análise do Quadro 1, pode-se afirmar que a combinação dos tratamentos de processo biológico de lodos ativados e carvão ativado em pó, traz um melhor desempenho no tratamento e com custo relativamente moderado, quando comparado a outros métodos mostrados, demonstrando que esta combinação tem um custo viável e um resultado bem satisfátorio.

Uma alternativa à utilização do carvão ativado para realizar a adsorção são os resíduos da construção civil (RCCs), alguns estudos procuraram avaliaram a capacidade de adsorção da cerâmica vermelha para efetuar o processo. Um ensaio de adsorção de efluentes de indústrias têxteis, realizado por SILVA (2017), com cerâmica vermelha como adsorvente obteve bons resultados. Para as análises, $250 \mathrm{~g}$ da cerâmica foi submetido a uma solução com concentração de corante de $5 \mathrm{~g} / \mathrm{l}$ durante $5 \mathrm{~h}$. Esse processo foi relizado com duas granulações, de 1,21 a 2,4 mm e 2,41 a 4,8 mm, foi obtido o resultado de 99,5\% e 98,6\% de remoção do corante do efluente, respectivamente, obtendo então um resultado satisfatório ao propósito.

Os RCCs vêm sendo uma preocupação devido aos danos causados ao meio ambiente, o que viabiliza a substituição do carvão ativado pelo mesmo, tendo em vista que daria uma utilidade para os resíduos e estes não seriam simplesmente descartado em aterros. Segundo Pinto (1999), é apontado que em 10 cidades brasileiras, consideradas de médio e grande porte, a massa de Resíduos da Construção e da 
Demolição (RCDs) gerada varia de 230 a $660 \mathrm{~kg} / \mathrm{hab} / \mathrm{ano}$, resultando em 41 a $70 \%$ da massa total dos resíduos sólidos. Além disso, há outro problema causado pela indústria da construção civil estando relacionado ao consumo excessivo dos recursos naturais. "A indústria de materiais consome aproximadamente 50\% dos recursos naturais extraídos" (CBCS, p. 78, 2014). John (2000) afirma que há uma estimativa de que no Brasil são consumidos 210 milhões de toneladas por ano de agregado na produção de argamassas e concretos, desconsiderando pavimentação e perdas.

Pelo apresentado, percebe-se que a adsorção é uma técnica que apresentada bons resultados quando empregada para remoção de corantes de efluentes de indústrias têxteis e pode ter sua eficiência aumentada quando combinada com outras técnicas, como supracitada. Ademais, observa-se que ao fazer uso da adsorção, pode-se optar por outros materiais além do carvão ativado, como é o caso dos RCCs e RCDs, contribuindo, assim, para melhor aproveitamento de resíduos e minimizando os danos ambientais provados tanto pelos RCCs e RCDs quando pelos efluentes de indústrias têxteis.

\section{CONSIDERAÇÕES FINAIS}

Diante das informações obtidas por meia desta revisão literária percebe-se que o processo de adsorção é atrativo pelo seu rendimento e custo, e se associado, por exemplo, ao processo biológico de lodo ativado os resultados melhoram ainda mais, elevando assim a qualidade do efluente após o tratamento.

Ainda sobre o processo de adsorção, onde os filtros mais usados são os de carvão ativado, há uma gama enorme em questão ambiental na parte de sustentabilidade, permitindo por exemplo montagem de filtros dos resíduos da contrução civil, como telhas, cerâmicas, dentre outros, onde, neste caso, permitiria resolução de dois problemas trabalhando em conjunto por conta do descarte dos resíduos e o efluente ao ter retorno ao meio ambiente.

Pode-se afirmar também que mesmo entre estes métodos apresentados, ainda há muito a ser pesquisado e desenvolvido para ter melhorias nas etapas de tratamento de efluentes visando um processo com foco na sustentabilidade.

\section{AGRADECIMENTOS}

Agradecemos especialmente a Faculdades Integradas Einstein de Limeira pela oportunidade e incentivo a pesquisa científica.

\section{REFERÊNCIAS}

[1] AGOPYAN, V.; JOHN, V. M.; GOLDEMBERG, J. (coord). O Desafio da Sustentabilidade na Construção Civil: volume 5, São Paulo: Blucher, 2011.

[2] ALMEIDA, E. J. R.; CORSO, C. R. Comparative study of toxicity of azo dye Procion Red MX-5B following biosorption and biodegradation treatments with the fungi Aspergillus nigerand Aspergillus terreus. Chemosphere, v. 112, p. 317-322, 2014.

[3] BLANCO, J.; FERNÁNDEZ, P.; GERNJAK, W.; MALATO, S.; MALDONADO, M. I.; OLLER, I.; PASSARINHO, P. C. Photocatalytic degradation of EU priority substances: A comparison between TiO2 and Fenton plus photo-Fenton in a solar pilot plant. Journal of Photochemistry and Photobiology A: Chemistry, v. 185, p. 354-363, 2007.

[4] Bohana, M. C. V; Jesus G. D; Marchi C. M. D. F. RESÍDUOS DE CONSTRUÇão CIVIL: Desafios e soluções propostos pelos Objetivos de Desenvolvimento Sustentável. Universidade Católica do Salvador, SEMOC, 2019.

[5] CARNEIRO, E. V.; LEÃO, M. M. D.; NETO, M. L. F.;RIBEIRO, E. D. L.;SCHWAB, W. K.;SOARES, A. F. S.; TORQUETI, Z. S. C. Controle ambientalna indústria têxtil: acabamento de malhas. Belo Horizonte: SEGRAC 2002.356 p. Projeto Minas Ambiente.

[6] CHANG, J. S.; GOVINDWAR, S. P.;SARATALE, G. D.; SARATALE, R. G. Bacterial decolorization and degradation of azo dyes: A review. Journal of the Taiwan institute of Chemical Engineers, v. 42, p. 138-157, 2011.

[7] CONSELHO BRASILEIRO DE CONSTRUÇÃO SUSTENTÁVEL - CBCS. Aspectos da Construção Sustentável no Brasil e Promoção de Políticas Públicas. Subsídios para a promoção da Construção Civil Sustentável. Versão 1, Nov. 2014.

[8] GUARATINI, C. C. I.; ZANONI, M. V. B. Corantes têxteis. Química Nova, v. 23, n. 01, p. 71-78, 2000.

[9] NASCIMENTO, Ronaldo Ferreira do Nascimento, et al. Adsorção - aspectos teóricos e aplicações ambientais, Fortaleza 2014. 
[10] PINTO, T. de Paula. Metodologia para a gestão diferenciada de resíduos sólidos da construção urbana. São Paulo, 1999. 189 p. Tese de Doutorado - Escola Politécnica da Universidade de São Paulo. Departamento de Engenharia de Construção Civil. São Paulo, 1999.

[11] SILVA, PAULO OZEREDE da. Métodos de tratamento das indústrias têxteis. UFMG2013, disponível em: <https://repositorio.ufmg.br/handle/1843/BUBD-A2CJNF>. Acesso em 04 de julho de 2020.

[12] SILVA, Alex Barbosa Campos; ANDRADE, Ricardo Mauricio Freitas; FREIRE, Flavio Bentes; Nagalli, André; CARVALHO, Karina Querne; PASSIG, Fernando Hermes; KREUTZ, Cristine. Análise da utilização de cerâmica vermelha como adsorvente na remoção do corante têxtil Direct Blue de uma solução aquosa, V.22 N.03 - 2017. 


\section{Capítulo 13}

Influência de condições operacionais no processo de pervaporação aplicado a efluentes têxteis sintéticos com corantes reativo

Gabriela Simon

Miriam Albara

Rita de Cássia Siqueira Curto Valle

Ricardo Antonio Francisco Machado

Cintia Marangoni

Resumo: A indústria têxtil está em crescente busca por soluções para a grande geração de águas residuais decorrente de seus processos. Tendo como principal resíduo o corante, tóxico ao meio ambiente e de difícil degradação, processos para reúso de água são uma forma de mitigar o impacto ambiental dos efluentes gerados. Neste sentido, processos com membranas como o de pervaporação são promissores pois são seletivos. Assim, o objetivo deste trabalho é avaliar as condições operacionais do processo de pervaporação para tratamento de resíduos da indústria têxtil, utilizando a membrana plana comercial de poliamida (PA) - DOW Filmtec ${ }^{\mathrm{TM}}$, variando-se os parâmetros de temperatura de alimentação $\left(45^{\circ} \mathrm{C}\right.$ e $\left.60^{\circ} \mathrm{C}\right)$ e vazão de alimentação $(0,7 \mathrm{~L} / \mathrm{min}$ e 1,5 L/min), de soluções aquosas com corante reativos. A partir da análise do planejamento fatorial observou-se que o fator mais importante para o fluxo de permeado é a temperatura da alimentação, com efeito positivo sobre a resposta. Foi observado que a concentração do corante no permeado não depende das condições operacionais isoladas, e sim da interação entre estas. Uma vez que seletividade da membrana é dependente da composição de alimentação e das condições operacionais utilizadas, conclui-se que o processo é viável para reúso de água e que valores mais elevados de temperatura e de vazão de alimentação devem ser empregados para incrementar o fluxo de água recuperada com a qualidade desejada (ausência de corante).

Palavras-chave: Corante reativo; Efluente têxtil; Pervaporação; Planejamento fatorial. 


\section{INTRODUÇ̃̃O}

A reutilização de águas residuais industriais juntamente com o conceito de zero descarga de líquido (Zero Liquid Discharge - ZLD) têm sido uma tendência crescente em virtude dos fatores relacionados à gestão sustentável da água, consequência da escassez deste insumo e das fortes regulamentações de descarte de efluentes. De fato, há uma crescente preocupação do setor industrial com relação às exigências de processos ecologicamente corretos que promovam um desenvolvimento sustentável (SILVA et al., 2018).

Resíduos das atividades industriais causam sérios prejuízos ao meio ambiente, dentre os quais cita-se os efluentes das indústrias têxteis. 0 beneficiamento têxtil, gera em torno de 50 a $100 \mathrm{~L}$ de efluente por quilo de tecido produzido, sendo a etapa de tingimento a mais preocupante devido à variedade e complexidade dos produtos químicos empregados. Entre os compostos químicos, os corantes têm atraído atenção devido ao alto potencial de poluição que apresentam (ALMEIDA et al., 2016).

Neste sentido, a indústria têxtil, grande consumidora e poluidora deste insumo, necessita o aprimoramento de técnicas para o tratamento e reúso de águas. 0 setor vem considerando a água como um insumo relevante em relação aos custos assim como a maior cobrança na utilização racional dos recursos naturais. Alternativas para reutilizar águas residuais têm sido incentivadas e processos de separação com membranas são atrativos, visto que apresentam elevada seletividade (ONG et al., 2016). Tais processos para recuperação de águas residuais da indústria têxtil são promissores visto que a descarga em temperaturas elevadas reduz o impacto negativo no custo do aquecimento da corrente de alimentação.

A potencialidade de processos de destilação por membranas para separação de corantes em misturas sintéticas bem como em efluentes industriais já foi demonstrada (RAMLOW et al, 2019a; 2019b). Porém, estudos são necessários para ampliar a possibilidade de aplicação de processos de separação com membranas. Como alternativa, a pervaporação visa separar as misturas líquidas, explorando as diferenças de solução e difusão dos componentes através de uma membrana densa. Um componente da mistura líquida da alimentação passa através da membrana para o lado do permeado, passando para a fase gasosa sob condições de baixa pressão (vácuo). 0 processo transmembrana não é determinado pela diferença relativa de volatilidade dos componentes da mistura, mas na diferença de sorção e dessorção dos componentes de alimentação na membrana (GUAN et al., 2020).

Pesquisas nesta área são relacionadas a recuperação/produção de biocombustíveis (JYOTHI et al., 2019) e tratamento de efluentes, como a separação de fenol (DING et al., 2016) e amônia (YANG et al., 2018). Aplicações em dessalinização (ZHANG et al., 2018) e efluentes têxteis (RAMLOW et al., 2019) relataram o uso de membranas hidrofílicas para reúso de água. Neste sentido, o objetivo deste trabalho é avaliar as condições operacionais no processo de pervaporação aplicado ao reuso de água de efluentes têxteis.

\section{METODOLOGIA}

Ensaios foram realizados com membrana plana comercial de poliamida (DOW Filmtec ${ }^{\mathrm{TM}}$ BW30) (Figura 1) e com soluções aquosas de $30 \mathrm{mg} / \mathrm{L}$ com corante preto reativo (RB) Tiafix RBL 133\% (Aupicor Química Ltda). Apesar de sua resistência elevada devido a espessura, esta membrana foi selecionada devido a elevada cpacidade de rejeição a solutos (conforme indicado pelo fornecedor). Os ensaios foram conduzidos com duração de $120 \mathrm{~min}$, com pressão de permeado abaixo de $10 \mathrm{mmHg}$ e a temperatura do banho de condensação a $-2{ }^{\circ} \mathrm{C}$.

A avaliação das condições operacionais foi realizada a partir de análise estatística (software Statistic) de um planejamento fatorial $2^{2}$. Utilizou-se como variáveis independentes a temperatura e a vazão de alimentação (Tabela 1) e como variáveis dependentes o fluxo de permeado e a concentração do corante no permeado, conforme Equações 1 e 2.

$$
\begin{aligned}
& J=\frac{\Delta m}{A \cdot \Delta t} \\
& R=\left(1-\frac{C_{p}}{C_{a}}\right) 100
\end{aligned}
$$


Figura 1: Diagrama esquemático da unidade de pervaporação.

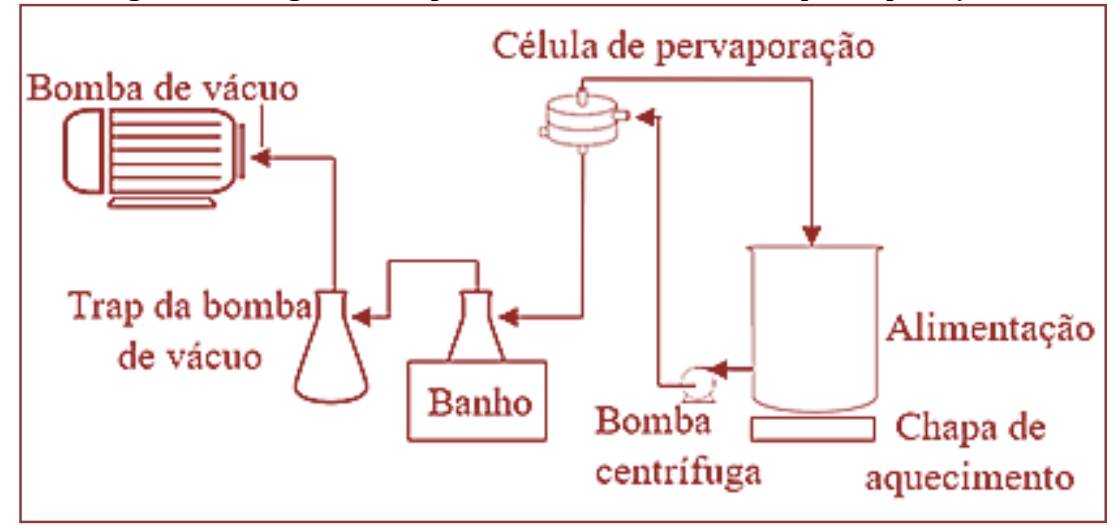

Tabela 1: Planejamento Fatorial $2^{2}$ com as variáveis independentes

\begin{tabular}{|c|c|c|}
\hline Experimentos & Temperatura $(\stackrel{\circ}{ } \mathrm{C})$ & Vazão de alimentação $(\mathrm{L} / \mathrm{min})$ \\
\hline 1 & $45(-1)$ & $0,7(-1)$ \\
\hline 2 & $60(+1)$ & $0,7(-1)$ \\
\hline 3 & $45(-1)$ & $1,5(+1)$ \\
\hline 4 & $60(+1)$ & $1,5(+1)$ \\
\hline
\end{tabular}

\section{RESULTADOS E DISCUSSÃO}

Os resultados obtidos são apresentados na Tabela 2 e a influência dos fatores nas variáveis independentes é apresentado nas Figuras 2 e 3. A análise de grandeza dos efeitos é ilustrada nas Figuras 4 e 5.

Observa-se na Tabela 2 que os valores de fluxo obtidos estão de acordo com os obtidos com outra membrana comercial de poliamida - NF 90 (RAMLOW et al., 2020) e que os valores de concentração de corante no permeado são baixos, indicando mais de $98 \%$ de rejeição à passagem de corante. Estes aspectos indicam a viabilidade do uso da membrana de poliamida BW 30 para separação de corantes de águas residuais têxteis.

Tabela 2: Resultados experimentais de fluxo e concentração de permeado

\begin{tabular}{|c|c|c|}
\hline Experimento & \multicolumn{1}{c|}{ Fluxo $\left(\mathrm{kg} / \mathrm{m}^{2}\right)$} & Conc. do permeado $(\mathrm{mg} / \mathrm{L})$ \\
\hline 1 & 0,57 & 3,27 \\
\hline 2 & 3,40 & 3,01 \\
\hline 3 & 1,37 & 3,01 \\
\hline 4 & 3,70 & 2,89 \\
\hline
\end{tabular}

Observando as figuras 2 e 3, percebe-se a influência positiva dos fatores no fluxo do permeado e negativa na concentração. Ou seja, temperaturas e vazões de alimentação mais altas incrementam o fluxo de permeado, e reduzem a concentração de corante no permeado (aumentam a rejeição). 
Figura 2: Influência dos fatores no fluxo de permeado
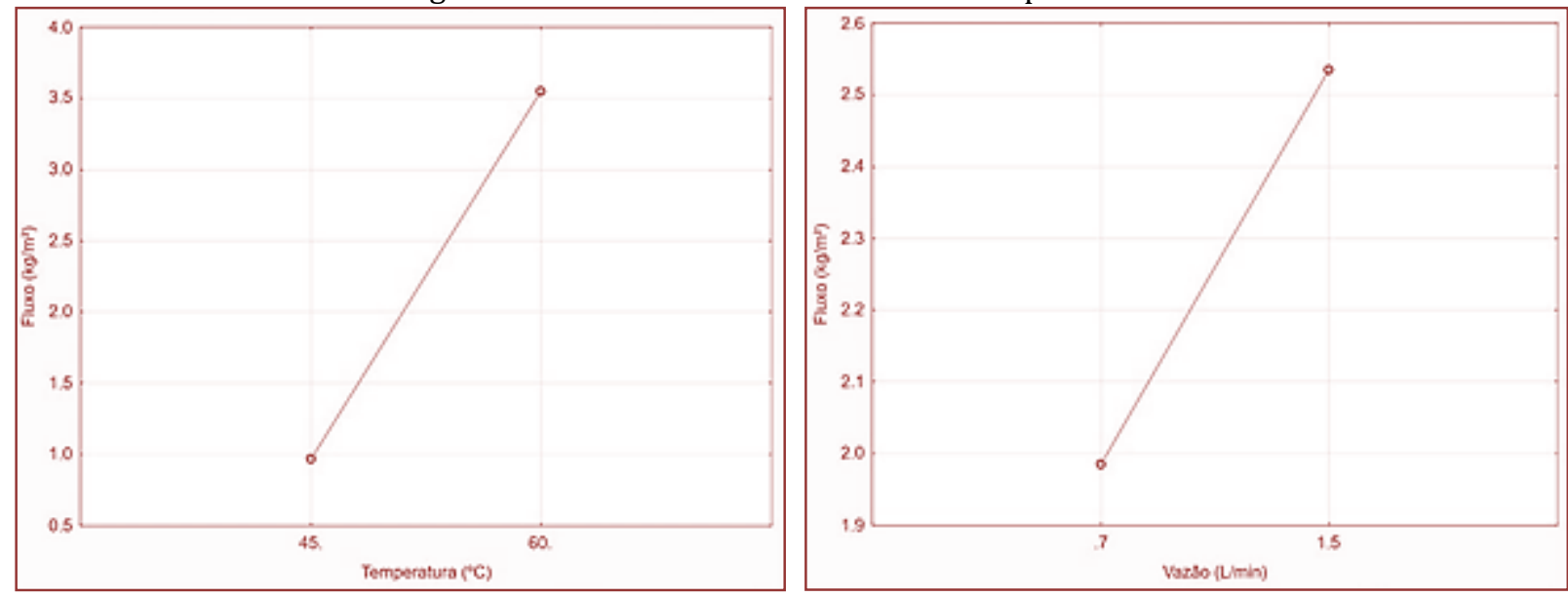

Figura 3: Influência dos fatores na concentração de permeado
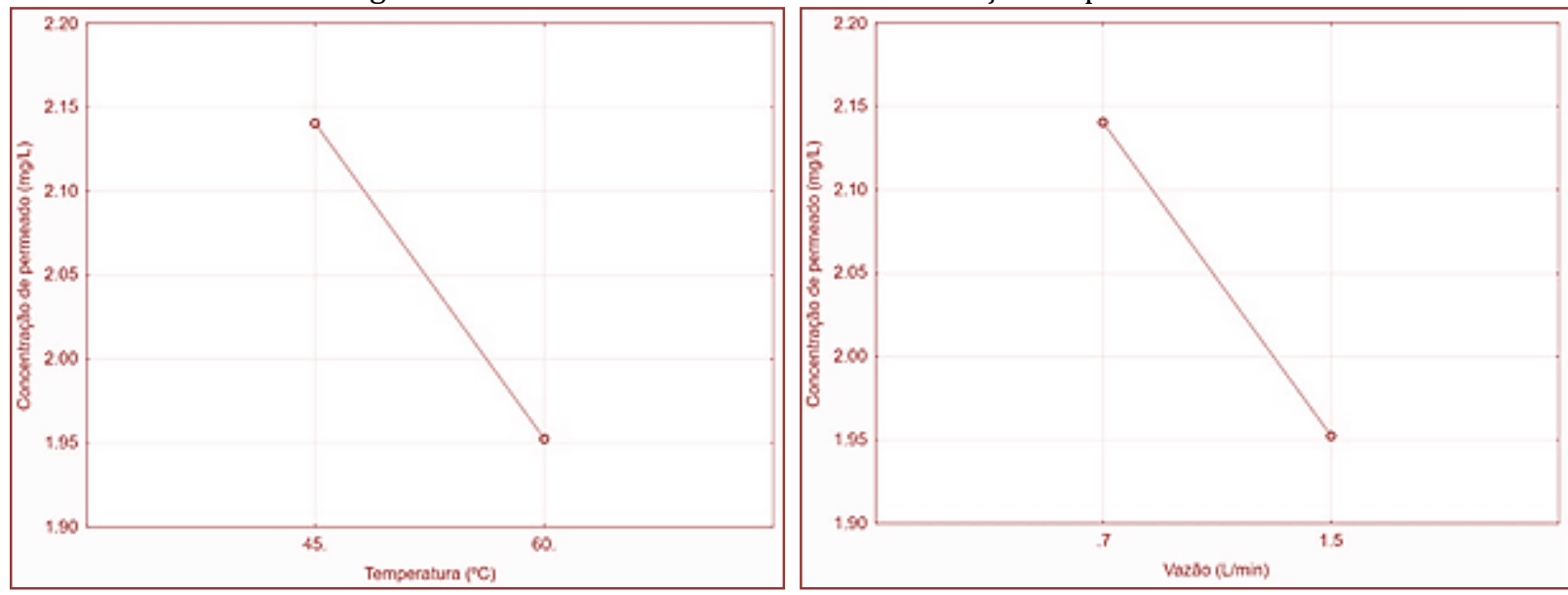

A observação da análise da ordem de grandeza dos efeitos demonstra que a temperatura da alimentação é o fator mais importante para o fluxo de permeado (efeito positivo quase $5 \mathrm{x}$ maior do que a vazão). Este aspecto era esperado, pois em temperaturas elevadas ocorre maior formação de vapor. Como águas residuais de processos têxteis são descartadas em temperaturas altas, este fator é uma vantagem para o uso da pervaporação.

Em relação a concentração de corante no permeado, a interação entre as duas variáveis apresenta-se como fator dominante no processo. Este comportamento é explicado pela importância do regime de escoamento, que determina diretamente a vazão de alimentação. 
Figura 4: Análise de grandeza dos efeitos em relação ao fluxo de permeado

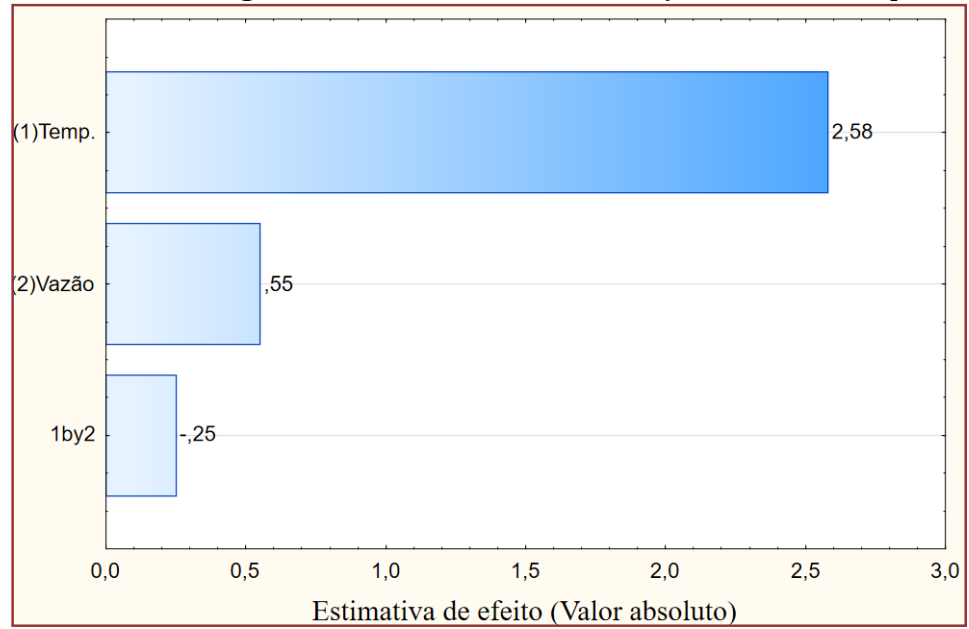

Figura 5: Análise de grandeza dos efeitos em relação a concentração de permeado.

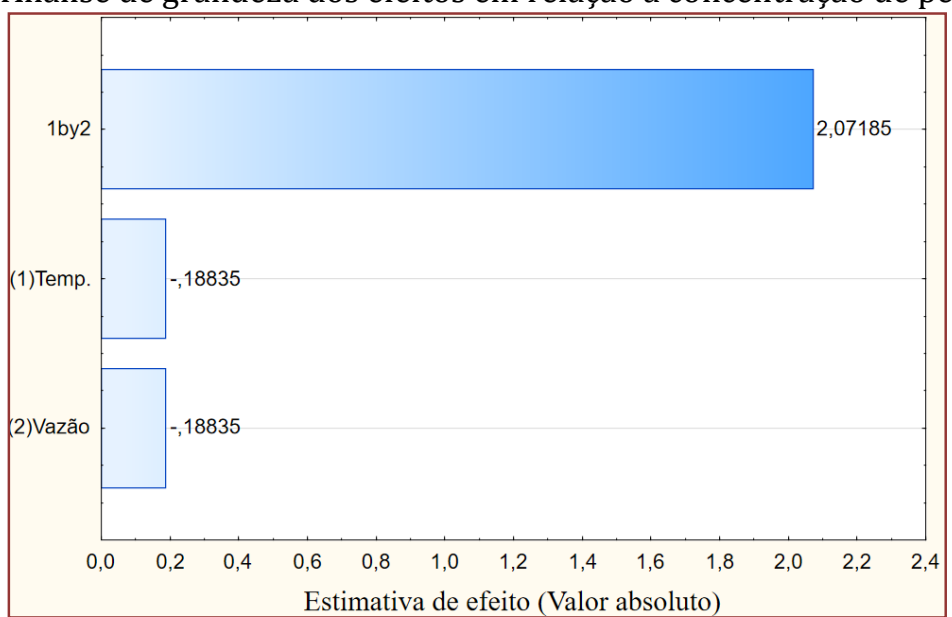

\section{CONCLUSÕES}

$\mathrm{Na}$ indústria têxtil, efluentes gerados são escoados a altas temperaturas e possuem elevada carga de sólidos e neste sentido a potencialidade do uso da pervaporação com uma membrana comercial de poliamida foi demonstrada decorrente dos resultados de elevada taxa de rejeição.

Os resultados apresentados demonstram a potencialidade da membrana utilizada (BW30) para recuperação de água a partir de efluentes têxteis. Indica-se a utilização dos valores mais altos de temperatura e vazão da alimentação visando o incremento do fluxo e a baixa concentração de corante no permeado para garantir a qualidade desejada da água.

\section{AGRADECIMENTOS}

O presente trabalho foi realizado com apoio da Coordenação de Aperfeiçoamento de Pessoal de Nível Superior - Brasil (CAPES) - Código de Financiamento 001. Os autores também agradecem ao CNPq pelo suporte financeiro na forma de bolsa PIBIC. 


\section{REFERÊNCIAS}

[1] ALMEIDA, E. J. R. et al. A indústria têxtil no Brasil: Uma revisão dos seus impactos ambientais e possíveis tratamentos para os seus efluentes. Ministério Público Federal - Projeto Qualidade da Água, Brasília, p. 1-18, nov. 2016.

[2] DING, C. et al. ZIF-8 incorporated polyether block amide membrane for phenol permselective pervaporation with high efficiency. Separation and Purification Technology, v. 166, p. 252-261, 2016.

[3] GUAN, K. et al. Graphene-based membranes for pervaporation processes. Chinese Journal of Chemical Engineering. In press, 2020. DOI:10.1016/j.cjche.2020.04.011.

[4] JYOTHI, M.S. et al. Membranes for dehydration of alcohols via pervaporation, Journal of Environmental Management, v. 242, p. 415-429, 2019.

[5] ONG, Y.K. et al. Recent membrane development for pervaporation processes. Progress in Polymer Science, v. 57, p. 1-31, 2016.

[6] RAMLOW, H. et al. Direct Contact Membrane Distillation Applied to Colored Reactive or Disperse Dye Solutions. Chemical Engineering and Technology, v. 42, n. 5, p. 1045-1052, 2019a.

[7] RAMLOW, H. et al. Direct contact membrane distillation applied to wastewaters from different stages of the textile process. Chemical Engineering Communications, v. 0, n. 0, p. 1-12, 2019b.

[8] RAMLOW, H. et al. Intensification of water reclamation from textile dyeing wastewater using thermal membrane technologies - Performance comparison of vacuum membrane distillation and thermopervaporation. Chemical Engineering and Processing - Process Intensification, v. 146, p. 107695, 2019c.

[9] SILVA, L.G.M. et al. Chemical and electrochemical advanced oxidation processes as a polishing step for textile wastewater treatment: A study regarding the discharge into the environment and the reuse in the textile industry. Journal of Cleaner Production, v. 198, p. 430-442, 2018.

[10] YANG, X. et al. Inter-layer free cobalt-doped silica membranes for pervaporation of ammonia solutions. Journal of Membrane Science, v. 553, p. 111-116, 2018.

[11] ZHANG, R., et al. Fabrication of high-performance PVA/PAN composite pervaporation membranes crosslinked by PMDA for wastewater desalination. Petroleum Science, v. 15, p. 146-156, 2018. 


\section{Capítulo 14}

Resíduos sólidos domésticos em Comunidades Rurais: A realidade da Escola Municipal Ângelo Ricardo em Frutal - MG

\section{Eliana Gomes de Paula e Silva}

Aline Nunes de Souza

Lidiane Aparecida Alves

Adriano Reis de Paula e Silva

Fábio Rodrigues da Silva

Resumo: Com foco na educação em gestão de resíduos sólidos domésticos, a qual consiste em oportunidade e possibilidade de se aliar o ensino às práticas sustentáveis de baixa tecnologia e custo, o presente texto descreve as ações de gestão dos resíduos sólidos domésticos de uma escola pública localizada no espaço rural de Frutal-MG. Nesse sentido, com base nos pressupostos teóricos sobre o tema em questão, foram a coletadas informações e dados de modo a averiguar as práticas no ambiente escolar e proporcionar à comunidade escolar maior conhecimento sobre os aspectos ambientais do manejo dos resíduos sólidos domésticos. Durante a realização dos trabalhos foram percebidas mudanças no processo de gestão dos resíduos por parte da equipe gestora da escola. Essa foi uma iniciativa pioneira em relação à busca pelo controle da gestão dos resíduos domésticos, sendo que o despertar para os problemas socioambientais relacionados aos resíduos sólidos domésticos e suas possíveis soluções teve/terá grande relevância, quiçá como modelo para a gestão de resíduos sólidos domésticos e promoção da qualidade ambiental na comunidade rural. Afinal, a realização do projeto contribuiu para a construção do conhecimento e formação de cidadãos comprometidos em cuidar do ambiente. Os resultados imediatos foram positivos, sendo que para o longo prazo acredita-se que serão ampliados, pois a comunidade escolar se sensibilizou com a problemática e adotou novas práticas em relação aos resíduos sólidos. Ademais, as mudanças de comportamento ocorridas na escola podem ser continuamente aperfeiçoadas, bem como abranger a comunidade externa.

Palavras-chave: Resíduos sólidos; Compostagem; Reciclagem; Incineração; Escola rural. 


\section{INTRODUÇ̃̃O}

A Educação Ambiental se torna condição essencial para a preservação do meio ambiente, pois

envolve o entendimento de uma educação cidadã, responsável, crítica, participativa, em que cada sujeito aprende com conhecimentos científicos e com o reconhecimento dos saberes tradicionais, possibilitando a tomada de decisões transformadoras, a partir do meio ambiente natural ou construído no qual as pessoas se integram (BRASIL, 2013, p. 535).

Projetos de Educação Ambiental com foco na gestão de resíduos sólidos, em ambientes educacionais têm resultados promissores, considerando diferentes etapas do ensino, conforme atestam os trabalhos de Da Silva Souza (2020) e Barros (2013), o primeiro em uma escola de ensino fundamental e o segundo em contexto universitário.

Segundo Jürgensen (2019), estima-se que cada estudante produz diariamente 40 gramas de resíduos recicláveis secos, 42 gramas de rejeitos e 134 gramas de resíduos orgânicos. Logo, entre $40 \%$ e $50 \%$ do que é gerado pela escola refere-se à fração orgânica: resíduos de alimentos e da manutenção de suas áreas verdes. Os resíduos sólidos considerados neste trabalho são aqueles classificados como Resíduos Sólidos Agrosilvopastoris II (Inorgânicos), que inclui os resíduos sólidos domésticos (RSD) da área rural, conforme classificação prevista pelo documento preliminar do Plano Nacional de Resíduos Sólidos (BRASIL, 2011). Lima e Paulo (2018, p. 1583) mencionam que a coleta de resíduos sólidos em áreas rurais compreende apenas $27 \%$ da população, o que reforça a necessidade de ações para a gestão ambientalmente correta dos resíduos sólidos das comunidades rurais e, adicionalmente, a promoção de ações para educação ambiental.

Em 2019 foi desenvolvido o projeto "Resíduos sólidos domésticos em comunidades rurais" na Escola Municipal Ângelo Ricardo, às margens da Rodovia BR-153, KM 181, Zona Rural do município de Frutal-MG. 0 projeto objetivou averiguar as práticas da escola quanto à gestão dos resíduos sólidos domésticos, promover reflexões quanto aos aspectos socioambientais dessas práticas e, por conseguinte, a adoção de ações que contribuem para a preservação ambiental, em conformidade com várias metas da Agenda 2030 para o Desenvolvimento Sustentável estabelecida pela ONU (2015).

\section{METODOLOGIA}

O estudo teve caráter exploratório-descritivo: exploratório porque buscou esclarecer conceitos e ideias, formulando hipóteses pesquisáveis para estudos posteriores; e descritiva porque descreveu as características de determinado fenômeno estabelecendo relações entre variáveis (GIL, 2008).

Nesse sentido, além de uma revisão de literatura, para fundamentação com os pressupostos teóricos sobre o tema de estudo, foi realizada a coleta de informações e dados, de modo a averiguar as práticas no ambiente escolar, e foram desenvolvidas atividades guiadas com os alunos do 9o ano do ensino fundamental, para proporcionar aos envolvidos maior conhecimento sobre os aspectos ambientais quanto ao manejo dos resíduos sólidos domésticos nas comunidades rurais.

Para descrever as características do descarte desses resíduos na Escola Municipal Ângelo Ricardo foram realizados observações no dia a dia do ambiente escolar e encontros com a equipe gestora da escola e de Serviços Gerais, Limpeza e Manutenção.

A temática foi trabalhada com os alunos do 9o ano do Ensino Fundamental durante as aulas de Geografia. Foram realizadas atividades guiadas acerca do tema Gestão de Resíduos Sólidos, envolvendo palestras em parceria com a Secretaria de Meio Ambiente. Apesar de se tratar de um tema de abordagem transversal no currículo escolar, a escolha pela disciplina de Geografia se deu pelo fato de esta abordar, em seu terceiro eixo de conteúdos para o quarto ciclo do ensino fundamental, "modernização, modos de vida e a problemática ambiental", tendo como alguns dos parâmetros "recursos naturais - esgotabilidade e reversibilidade: usar e recuperar", "o que é e para onde vai o lixo urbano: tratamento e destino do lixo;", "reciclagem dos resíduos industriais, hospitalares e domésticos" (BRASIL, 1998, p. 126-127). 


\section{RESULTADOS E DISCUSSÃO}

Na Escola Municipal Ângelo Ricardo, mesmo de formas precárias, existia a diferentes destinações para os resíduos gerados: coleta seletiva de resíduos recicláveis, compostagem de resíduos orgânicos e queima de rejeitos.

Os recicláveis da escola advindos dos coletores seletivos instalados nos ambientes de maior circulação de pessoas dentro da escola e das atividades escolares, em seus diferentes ambientes como cozinha e salas de aula eram repassados, em BIG-BAGs, à Associação de Catadores de Materiais Recicláveis do Município de Frutal (ASCAFRU).

No entanto, esses Bag's ficavam a céu aberto no quintal da escola. Durante a realização da pesquisa, a direção realizou a construção de uma cobertura para acomodação do Big-bag. Além disso, anteriormente não havia programação para o recolhimento, a qual foi implementada e ocorre mensalmente, ou mediante demanda.

Para tratamento dos resíduos orgânicos, provenientes da manutenção de áreas verdes da escola e da separação prévia dos resíduos gerados pela cozinha, a escola, em parceria com a Secretaria Municipal de Meio Ambiente, construiu uma composteira. Antes os resíduos orgânicos eram queimados e/ou destinavam-se à alimentação animal.

A realização do projeto de pesquisa na escola instigou a equipe escolar a sistematizar a compostagem e efetivar de seu funcionamento, com utilização da matéria orgânica resultante na horta da escola. No processo, há participação dos alunos do 9o ano do Ensino Fundamental, a partir da disciplina de Técnicas Agrícolas.

Os demais resíduos, que não eram reciclados, destinavam-se à queima realizada a céu aberto, nos fundos da escola e sem o devido controle o que gerava riscos. A queima dos resíduos era alternativa para minimizar o transtorno decorrente do acúmulo dos resíduos da escola e da comunidade, em local reservado pela prefeitura da cidade para coleta semanal de resíduos daquela comunidade. Tal local é sem estrutura de cercamento ou proteção contra intempéries, espalhando resíduos e atraindo animais.

Durante a pesquisa, a equipe escolar construiu um incinerador para a queima controlada dos rejeitos. Apesar de ainda não ser uma prática ideal, tal procedimento trouxe melhorias reduzindo a quantidade de fumaça emitida e maior segurança, deixando de contaminar o solo e impedindo que o fogo se propague para as áreas vizinhas.

Os estudantes participam de maneira ativa no processo de compostagem promovido pela escola, trazem os resíduos recicláveis oriundos de suas residências e são os responsáveis pela aplicação do adubo natural na horta e nos jardins da escola.

Durante a realização do projeto a equipe escolar realizou algumas modificações e melhorias no processo de gestão dos resíduos. A escola melhorou o acondicionamento do BAG, possibilitou o recolhimento de recicláveis trazidos das casas dos alunos, realizou a esquematização para efetivação da compostagem e promoveu a construção do incinerador para melhor controle da queima.

Acredita-se que as ações de reflexão surtiram efeito positivo ao proporcionar uma iniciação do processo de transformação e ressignificação das práticas adotadas em gestão de resíduos sólidos em toda a comunidade escolar. Destaca-se o esforço da equipe escolar na tentativa de minimização de um problema causado pela situação a qual lhe é imposta na melhoria da gestão dos rejeitos gerados (não recicláveis e não orgânicos).

Os resultados deste trabalho foram apresentados na "I Feira de Ciências da UEMG Frutal: Inovação e Meio Ambiente", que ocorreu nas dependências da Unidade de Frutal da Universidade do Estado de Minas Gerais (UEMG), em 18 de setembro de 2019, como representação da Escola Municipal Ângelo Ricardo no referido evento.

\section{CONSIDERAÇÕES FINAIS}

A pesquisa desenvolvida comprovou que a escola faz a separação dos principais resíduos sólidos gerados em suas atividades diárias e, em um processo contínuo e gradual de adequação, promove melhorias nas práticas de destinação e gestão dos resíduos gerados, aliando conhecimentos científicos a uma ressignificação da cultura local. É possível notar, ainda, que a escola interage com a comunidade local, 
desenvolvendo ações que podem influenciar na adoção e valorização, por parte da comunidade, de ações relacionadas à destinação adequada dos resíduos sólidos.

Como trabalhos futuros, sugere-se um estudo para a proposição de ações de retenção de carbono da atmosfera, como contrabalanço à queima dos resíduos. Outra opção é analisar as práticas adotadas pelas famílias circunvizinhas à escola na gestão dos resíduos sólidos domésticos e as questões culturais que podem influenciar. Em longo prazo, destaca-se a possibilidade de desenvolvimento de um plano de ação para melhoria contínua da gestão de resíduos sólidos nesta localidade.

\section{REFERÊNCIAS}

[1] BARROS, R. M. et al. Design and implementation study of a Permanent Selective Collection Program (PSCP) on a University campus in Brazil. Resources, conservation and recycling, v. 80, p. 97-106, 2013.

[2] BRASIL, Secretaria de Educação Básica. Diretrizes Curriculares Nacionais Gerais da Educação Básica. Brasília: MEC/SEB/DICEI, 2013. 562p. ISBN: 978-857783-136-4.

[3] BRASIL. Secretaria de Educação Fundamental. Parâmetros Curriculares Nacionais: geografia. Brasília: MEC/SEF, 1998. 156p.

[4] BRASIL. Sistema Nacional de Informações sobre a Gestão dos Resíduos Sólidos. Plano Nacional de Resíduos Sólidos. Brasília-DF: MMA/SINIR, 2011. Versão preliminar para consulta pública. Disponível em: https://sinir.gov.br/planos-de-residuos-solidos. Acesso em: 28 jun. 2020.

[5] DA SILVA SOUZA, F. R. Educação Ambiental e sustentabilidade: uma intervenção emergente na escola. Revista Brasileira De Educação Ambiental (RevBEA), v. 15, n. 3, p. 115-121, 2020.

[6] GIL, A. C. Métodos e técnicas de pesquisa social. São Paulo: Atlas, 2008.

[7] JÜRGENSEN, M. R. Manual para gestão de resíduos orgânicos nas escolas. São Paulo: ABRELPE, 2019. Disponível em: http://abrelpe.org.br/publicacoes. Acesso em: 16 jun. 2020.

[8] LIMA, P. M.; PAULO, P. L. Solid-waste management in the rural area of BRAZIL: a case study in Quilombola communities. Journal of Material Cycles and Waste Management, Tókio, v. 20, issue 3, p. 1583-1593, jul. 2018.

[9] ORGANIZAÇÃO DAS NAÇÕES UNIDAS. Transformando Nosso Mundo: A Agenda 2030 para o

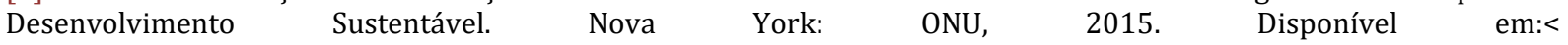
https://nacoesunidas.org/pos2015/agenda2030/>. Acesso em: 20 mai. 2018. 


\section{Capítulo 15}

Estudo da composição gravimétrica de resíduos sólidos produzidos pelo restaurante da Universidade Federal de Viçosa - Campus Florestal

\section{Brenda Silva Soares}

Laiane Ferreira da Silva

Matheus Morais de Souza

Hygor Aristides Victor Rossoni

Resumo: 0 estudo de composição gravimétrica consiste em uma ferramenta que auxilia na caracterização da geração quali-quantitativa dos resíduos sólidos, possibilitando a elaboração de planos de gerenciamento. Com isso, o objetivo do presente trabalho foi estudar a geração dos resíduos sólidos produzidos pelo Restaurante Universitário (RU) da Universidade Federal de Viçosa-Campus Florestal (UFV-CAF). 0 estudo da coleta, segregação e caracterização dos resíduos foi realizado no intervalo de uma semana, representando todas as três refeições diárias ofertadas pelo RU, sendo essas: café da manhã, almoço e jantar. Os resíduos foram classificados de acordo com as suas características em: papelão, papel, copos descartáveis, plástico PET, plástico duro, caixas de leite, trapos e matéria orgânica. Os resultados indicam que a matéria orgânica apresentou maior quantidade de geração média diária, representando 173,36 Kg $(97,8 \%)$ do total de resíduos coletados e o de menor valor foi o papelão com $0,34 \mathrm{Kg}$ $(0,18 \%)$. Além disso, foi possível constatar variações na quantidade de RS per capita produzidos em cada refeição, logo, torna-se necessário desenvolver práticas de Educação Ambiental junto à comunidade acadêmica visando à diminuição na geração desses resíduos e principalmente a redução do desperdício dos alimentos no preparo e após as refeições.

Palavras-chave: Comunidade Acadêmica; Educação Ambiental; Gerenciamento de Resíduos Sólidos. 


\section{INTRODUÇ̃̃O}

Segundo Adriano e Murata (2014), a discussão imposta diante da produção de resíduos sólidos (RS) tem ganhado bastante notoriedade em escala global, porém essa temática é desafiadora e apresenta diversas dificuldades, principalmente quando o questionamento se direciona para a maneira em que esses resíduos são manuseados e como é realizada a sua disposição final, visando principalmente à sustentabilidade ambiental, redução de custos e a promoção da saúde pública.

Diante dessa temática, foi promulgado no Brasil a Lei № 12.305, de 2 de agosto de 2010, a Política Nacional de Resíduos Sólidos, que dispõe sobre princípios, objetivos e instrumentos bem como sobre as diretrizes relativas à gestão integrada e ao gerenciamento de resíduos sólidos - incluindo os perigosos -, às responsabilidades dos geradores, do poder público e os instrumentos econômicos aplicáveis (BRASIL, 2010).

Tendo em vista a relevância voltada para questão do gerenciamento de resíduos sólidos, grande importância deve ser dada para a geração desses materiais em larga escala, como é o caso de instituições de ensino, onde a quantidade de resíduos é potencializada devido ao alto número de estudantes e frequentadores do local, tornando necessários estudos aprofundados com o intuito de contribuir em projetos visando melhorias econômicas, sociais e ambientais.

Com base neste contexto, o intuito do presente trabalho foi o de realizar o estudo da composição gravimétrica de resíduos sólidos produzidos no Restaurante Universitário (RU) da Universidade Federal de Viçosa - Campus Florestal (UFV-CAF).

\section{METODOLOGIA}

O estudo da composição gravimétrica realizado no Restaurante Universitário (RU), foi embasado de acordo com as orientações da Fundação Estadual de Meio Ambiente, que determina os procedimentos metodológicos para a realização da composição gravimétricas, bem como os equipamentos necessários para a condução das atividades (FEAM, 2019).

A duração do presente estudo foi de uma semana, equivalente a cinco dias letivos, excetuando o final de semana, tendo início no dia 02/12/2019 e encerrando em 06/12/2019, o qual possibilitou obter um panorama quali-quantitativo dos resíduos sólidos gerados durante a semana, nas refeições: café da manhã, almoço e jantar. Durante esse período foram servidas 5.217 refeições no Restaurante Universitário (RU), sendo deste valor, $17 \%$ referentes ao café da manhã, $57,2 \%$ ao almoço e $25,7 \%$ ao jantar.

A pesquisa foi realizada por meio de grupos compostos por três a quatro pesquisadores/colaboradores, sendo assim cada grupo se disponibilizou, em determinado horário das refeições (antes e após), para fazer a segregação e pesagem dos resíduos em orgânicos e não orgânicos. A obtenção dos dados deu-se a partir do acompanhamento desde início do preparo até o final de cada refeição.

É importante salientar que todos os envolvidos neste estudo, utilizaram Equipamentos de Proteção Individual (EPIs), visando à segurança para o manuseio dos resíduos. Além disso, foram utilizados sacos plásticos para facilitar a segregação da carga de resíduos, e posteriormente com o uso de uma balança de plataforma elétrica, com capacidade de $200 \mathrm{Kg}$ (precisão de 0,2g a 100g) para a pesagem dos mesmos.

\section{RESULTADOS E DISCUSSÃO}

De acordo com a ABNT NBR 10004/2004 (ABNT, 2004), os resíduos produzidos pelo RU, se enquadram na Classe II A, materiais não perigosos e não inertes. Observando os dados da Tabela 1, é notório que a massa orgânica representa a maioria dos RS $(96,8 \%)$ produzido no RU. Isso se deve ao fato das refeições almoço e jantar apresentarem maior quantidade de produtos não comestíveis gerados no preparo e nas sobras de alimentos não consumidos pelos frequentadores. Os resíduos não orgânicos obtiveram 3,2\% do total de materiais coletados. 
Tabela 1 - Média Diária Semanal da Composição Gravimétrica de Resíduos Sólidos do Restaurante Universitário da UFV-CAF

\begin{tabular}{|c|c|c|c|c|c|c|c|c|c|}
\hline \multirow{3}{*}{ Materiais } & \multicolumn{6}{|c|}{ Refeição } & \multirow{2}{*}{\multicolumn{2}{|c|}{ Total }} & \multirow{3}{*}{$\begin{array}{c}\text { Recomendação de } \\
\text { Destinação }\end{array}$} \\
\hline & \multicolumn{2}{|c|}{ Café da manhã } & \multicolumn{2}{|c|}{ Almoço } & \multicolumn{2}{|c|}{ Jantar } & & & \\
\hline & $\mathrm{Kg}$ & $\%$ & $\mathrm{Kg}$ & $\%$ & $\mathrm{Kg}$ & $\%$ & $\mathrm{Kg}$ & $\%$ & \\
\hline Papelão & 0,08 & 0,67 & 0,2 & 0,19 & 0,06 & 0,08 & 0,34 & 0,18 & \multirow{2}{*}{ Usina de triagem } \\
\hline Papel & 0 & 0 & 1 & 0,9 & 0 & 0 & 1 & 0,55 & \\
\hline Copo descartável & 0,9 & 7,6 & 0 & 0 & 0 & 0 & 0,9 & 0,5 & Aterro \\
\hline Plástico PET & 0,09 & 0,76 & 0,14 & 0,13 & 0,13 & 0,19 & 0,36 & 0,2 & \multirow{3}{*}{ Usina de triagem } \\
\hline Plástico duro & 0,16 & 1,35 & 0,38 & 0,37 & 0,5 & 0,74 & 1,04 & 0,58 & \\
\hline Caixa de leite & 0,52 & 4,39 & 0,1 & 0,09 & 0,08 & 0,11 & 0,7 & 0,39 & \\
\hline Trapos & 1,1 & 9,29 & 0,26 & 0,25 & 0,08 & 0,11 & 0,44 & 0,9 & Aterro \\
\hline Matéria orgânica & 8,98 & 75,9 & 98,88 & 97,93 & 66,34 & 98.73 & 173,36 & 96,77 & Compostagem \\
\hline Total & 11,83 & 100 & 100,96 & 100 & 67,19 & 100 & 179,14 & 100 & \\
\hline
\end{tabular}

Segundo a Lei 12.305, de 02 de agosto de 2010 (BRASIL, 2010), a destinação final dos resíduos sólidos deve ser ambientalmente adequada incluindo a reutilização, a reciclagem, a compostagem, a recuperação e o aproveitamento energético ou outras destinações admitidas pelos órgãos competentes. A realidade atual em relação à destinação dos resíduos do Restaurante Universitário (RU) consiste na separação e no condicionamento, sendo os orgânicos armazenados em um ambiente refrigerado e os não orgânicos em uma sala para resíduos secos, assim esperando a coleta ser realizada, sem uma destinação específica.

A Tabela 2, possibilita analisar a média diária de refeições e a produção média per capita de resíduos. 0 valor per capita referente ao café da manhã é 67,6g, almoço 169,11g e o jantar 249,77g. Cabe destacar que, nessa última situação ocorreu a deterioração de verduras antes do preparo da refeição jantar e consequentemente o descarte de 55,7 Kg desse alimento no dia 05/12/2019.

Segundo a Política Nacional de Resíduos Sólidos, o controle social e a gestão integrada podem ser uma solução viável para a minimização da geração de resíduos, visando à participação conjunta entre o RU e a comunidade, para a implementação e avaliação de políticas públicas relacionadas aos resíduos sólidos (BRASIL, 2010).

Tabela 2 - Características dos resíduos sólidos produzidos no RU da UFV-CAF

\begin{tabular}{|l|c|c|c|}
\multicolumn{1}{c}{ Características } & \multicolumn{3}{c}{ Refeição } \\
Quantidade de refeições diárias & Café da manhã & Almoço \\
\hline $\begin{array}{l}\text { Produção per capita de Resíduos (g) } \\
\text { resíduos por refeição/dia) }\end{array}$ & 175 & 597 & 269 \\
\hline
\end{tabular}

Autor: Próprio (2020)

\section{CONSIDERAÇÕES FINAIS}

A partir do presente estudo foi possível constatar que a maior proporção de resíduos no Restaurante Universitário (RU), é derivado da matéria orgânica proveniente principalmente das refeições almoço e jantar, sendo necessário o desenvolvimento de um gerenciamento interno, economicamente e ambientalmente viável, visando a diminuição na fonte de geração de resíduos, como a obtenção de verduras e frutas duas vezes por semana e a realização de um projeto de Educação Ambiental junto aos frequentadores e a comunidade acadêmica, visando a redução do desperdício de alimentos. 


\section{AGRADECIMENTOS}

Os autores agradecem aos Bolsistas de Iniciação Profissional (BIP/UFV): Agnes Brito, Emerson Fonseca Silva, Daniela Martins Cardoso, Henrique Marques Martins Chaves, Izabella Santana Neme Barbosa, Kathleen de Souza Garcia Rios, e Pollyana Morato Albino, Robert de Cassia Coelho; por terem contribuído durante o processo de aquisição dos dados referentes a esse estudo. E aos servidores da UFV-Campus Florestal as nutricionistas: Ana Clara Gonçalves Lopes e Renata Oliveira Castro, e ao Diretor de Assuntos Comunitários Elias Vasconcelos Rezende, por terem contribuído no planejamento e na logística para a realização do presente estudo.

\section{REFERÊNCIAS}

[1] ADRIANO, A.P.P.; MURATA, A.T. Caracterização e quantificação de resíduos sólidos em escola pública do município de Matinhos PR, para proposição de medidas de gestão de resíduos. Revista eletrônica em Gestão, Educação e Tecnologia Ambiental. Matinhos, PR. V. 19, n .1, jan-abr. 2015,p.30-37.

[2] ASSOCIAÇÃO BRASILEIRA DE NORMAS TÉCNICAS. ABNT NBR 10004: Resíduos Sólidos- Classificação. Rio de Janeiro, RJ. 2004.

[3] BRASIL. Lei 12.305, 2 de Agosto de 2010. Dispõe sobre a Política Nacional de Resíduos Sólidos, seus fins e mecanismos de formulação e aplicação, e dá outras diretrizes. Brasília, DF. 2010.

[4] FEAM. Fundação Estadual de Meio Ambiente. Estudo Gravimétrico de Resíduos Sólidos Urbanos. Belo Horizonte, MG. 2019 


\section{Capítulo 16}

Os poluentes e a toxicidade dos rejeitos de mineração de ferro: Efeitos do rompimento das barragens em Mariana e Brumadinho - MG

Jocimara Camargo da Silva

Carolina Carneiro de Freitas Scaquetti

Leonardo Granziera

Renata Kelly Mendes

Regina Marcia Longo

Resumo: A mineração é atividade que envolve a retirada e a separação mineral do meio ambiente, originando duas frações: o metal de interesse que segue para fins econômicos e os rejeitos, dispostos em barragem. Existem vários métodos de deposição dos rejeitos de mineração, entretanto, o maior custo dos métodos mais seguros faz com que, muitas vezes, as empresas assumam altos riscos de segurança. Como exemplo, cita-se os eventos ocorridos, em Mariana e Brumadinho, Minas Gerais, de rompimento das barragens dos rejeitos de mineração, acarretando grandes danos ambientais e sociais. 0 objetivo deste trabalho foi por meio de uma revisão bibliográfica, apresentar alguns dos poluentes presentes nos rejeitos de mineração de ferro e os seus efeitos ao meio ambiente e, de modo breve, discorrer sobre a toxicidade à população exposta, dando-se enfoque nos eventos citados. A busca pelos trabalhos foi realizada utilizando-se as plataformas Periódico CAPES e Google Acadêmico. Os efeitos da dispersão dos rejeitos no meio aquático envolvem alterações em suas características, de modo que prejudica a sobrevivência da biota presente. Ainda, o processo de bioacumulação e a exposição contínua pode levar os contaminantes metálicos até o organismo humano, de forma a provocar efeitos adversos devido a intoxicação. Conclui-se que as barragens utilizadas como depósito dos rejeitos oriundos do processo de beneficiamento do ferro usualmente construídas podem apresentar falhas, podendo causar danos irreparáveis ao meio ambiente e à população exposta.

Palavras-chave: Acidentes ambientais; Deposição de rejeito; Poluentes metálicos. 


\section{INTRODUÇÃO}

O processo de mineração envolve a retirada de minerais das minas subterrâneas, sendo necessário a separação do mineral de interesse. Após a separação, obtém-se duas frações: a com o mineral enriquecido que segue para fins econômicos, e a fração de rejeito que segue para uma barragem de contenção onde fica depositada (MUNIZ; OLIVEIRA-FILHO, 2006). A composição do rejeito varia de acordo com o tipo de metal beneficiado, bem como os reagentes utilizados para tal fim (CARDOZO; PIMENTA; ZINGANO, 2016).

Os métodos mais seguros de deposição dos rejeitos gerados por mineradoras envolvem um maior custo, fazendo com que, muitas vezes, as empresas assumam o alto risco de segurança e até mesmo, a violação dos diretos humanos. Como exemplo, cita-se os eventos ocorridos em Mariana e Brumadinho, ambas em Minas Gerais. Em Mariana, no dia 5 de novembro de 2015, ocorreu o rompimento da barragem de rejeitos Fundão, causando grandes danos ambientais e sociais. Pouco mais de três anos depois, aconteceu o rompimento da barragem de rejeitos da Mina do Feijão, em Brumadinho, causando, junto aos danos ao meio ambiente e social, a sensação de perplexidade e impotência por parte da população, afinal, tais eventos possuem responsáveis institucionais e individuais, fornecendo-os um caráter criminoso e não de desastre (HELLER, 2019).

Diante do exposto, o presente trabalho tem como objetivo apresentar alguns dos poluentes presentes em rejeitos de mineração de ferro, bem como seus efeitos sobre o meio ambiente e, de modo breve, a toxicidade nas pessoas expostas, dando-se enfoque nos eventos de rompimento das barragens de mineração em Mariana e Brumadinho-MG.

\section{METODOLOGIA}

O presente trabalho foi desenvolvido através de uma revisão bibliográfica utilizando-se as plataformas Periódico CAPES (campo Assunto) e Google Acadêmico para a busca. Utilizou-se as palavras-chave: mineração de ferro, mineração de ferro química, barragens de mineradoras de ferro, tipos de barragens, toxicidade ferro, toxicidade rejeitos mineração de ferro, ferro meio aquático. Não foi estipulado margem de data na busca, entretanto, as referências mais atuais foram preferidas.

\section{RESULTADOS E DISCUSSÃO}

Em relação à constituição dos sedimentos da Barragem de Germano, da Samarco Mineração S.A., em Mariana-MG, Pires et al. (2003) constataram uma maioria de ferro, seguido por dióxido de silício e alumínio. Nos testes de solubilidade e lixiviação foram encontrados os elementos-traços: cromo, cádmio, chumbo, manganês, ferro e sódio, sendo o sedimento classificado como inerte. 0 resíduo da mineração de ferro apresenta características de adsorção de metais em sua superfície, podendo atuar como barreira efetiva para diversos metais. No entanto, mudanças no meio, como no $\mathrm{pH}$, podem alterar esta capacidade (BASÍlIO et al., 2005). Desta forma, considerando-se o rompimento de uma barragem de mineração de ferro, as propriedades dos rejeitos, assim como as interações com o ambiente, passam ser de difícil determinação.

Silva, Cunha e Viglio (2016) realizaram análises de água e sedimento dos rios ao redor da barragem do Fundão da mineradora Samarco em Mariana-MG, após seu rompimento. Foram associados ao rejeito de mineração os valores elevados do ferro e manganês, alta turbidez e baixo nível oxigênio dissolvido. De modo similar, Cyrne et al. (2020), realizaram análises na água do rio Paraopeba após o rompimento da Barragem Mina Córrego do Feijão, Brumadinho-MG, e verificaram valores acima do permissível para alumínio e ferro dissolvido, assim como para manganês e níquel total. Em meio aquático, a introdução de tais rejeitos pode alterar as características fundamentais para a sobrevivência da biota que o habita.

Por meio da bioacumulação os poluentes metálicos podem ser transferidos ao homem, uma vez que a concentração de tais metais nos organismos aquáticos pode ser várias grandezas acima da concentração encontrada na água (CARMO; ABESSA; NETO, 2011; CYRNE et al., 2020). Já sobre a contaminação do solo, embora este apresente a característica de imobilização metálica, a dinâmica dos metais neste composto é difícil ser determinada, já que é dependente de diversos fatores, como o tipo de matéria orgânica que o constitui. Desta forma, a barreira natural fornecida pelo solo nem sempre é eficaz (MUNIZ; OLIVEIRAFILHO, 2006; SOUZA; MORASSUTI; DEUS, 2018). 
A exposição funcional ao arsênio, cádmio e cromo está relacionada à efeitos adversos como as lesões da pele até quadros clínicos graves, entre outros (MUNIZ; OLIVEIRA-FILHO, 2006). O ferro é um mineral essencial para o funcionamento do organismo humano, no entanto, uma alta concentração pode torná-lo um mineral tóxico (GROTTO, 2008; BRASIL, 2013). Em Brumadinho, após o rompimento da barragem os moradores apresentaram sintomas de intoxicação como vômitos e náuseas. Ainda, deve ser considerada a influência de tal evento no bem-estar psíquico da população. No dia do rompimento da barragem de Brumadinho, a Unidade Básica de saúde da cidade vizinha realizou atendimento para mais de 80 pessoas com pressão alta por conta da ansiedade e nervosismo (SUDRÉ; PINA, 2019).

Por fim, ressalta-se que, muitos dos danos provocados pelo rompimento das barragens são irreparáveis. Entretanto, é necessário considerar ações para a recuperação ou diminuição dos danos ao socioambiental, bem como avaliar as falhas existentes no sistema e suas reparações.

\section{CONCLUSÕES}

As barragens utilizadas como depósito dos rejeitos oriundos do processo de beneficiamento do ferro usualmente construídas podem apresentar falhas, podendo causar danos irreparáveis ao meio ambiente, bem como à população exposta. Como exemplo, cita-se os eventos do rompimento das barragens de rejeito do Fundão, em Mariana, e Mina Córrego do Feijão, em Brumadinho, Minas Gerais. Desta forma, o rompimento das barragens implicou na dispersão de todos os seus componentes no ambiente. As consequências foram avaliadas através de análises na água e no solo, constatando-se valores elevados de ferro, manganês, além de baixos níveis de oxigênio dissolvido. Outro fator preocupante é a bioacumulação que favorece a transferência desses poluentes ao homem, que pode passar a sentir vários efeitos adversos.

\section{AGRADECIMENTOS}

O presente trabalho foi realizado com apoio da Coordenação de Aperfeiçoamento de Pessoal de Nível Superior - Brasil (CAPES) - Código de Financiamento 001 (J.C.Silva).

\section{REFERÊNCIAS}

[1] BASÍlio, M. S. et al. Adsorção de $\mathrm{As}, \mathrm{Cu}, \mathrm{Pb}$ e $\mathrm{Cr}$ na avaliação da capacidade de fixação de metais por resíduo de mineradoras de ferro. Quim. Nova, v. 28, n. 5, p. 822-828, 2005.

[2] BRASIL. Ministério da saúde. Sobrecarga de ferro. Protocolo Clínico e Diretrizes Terapêuticas. Portaria SAS/MS no 1.324, de 25 de novembro de 2013.

[3] CARDOZO, F. A. C.; PIMENTA M. M.; ZINGANO, A. C. Métodos construtivos de barragens de rejeitos de mineração - uma revisão. HOLOS, v. 08, p. 87-85, 2016.

[4] CARMO, A. C.; ABESSA, D. M.S.; NETO, J. G. M. Metais em águas, sedimentos e peixes coletados no estuário de São VicenteSP, Brasil. O Mundo da Saúde, São Paulo, v. 35, n. 1, p. 64-70, 2011.

[5] CYRNE, R. C. O. et al. Remoção de Metais Pesados da Água do Rio Paraopeba após o Rompimento da Barragem Mina Córrego do Feijão. Braz. J. of Develop., Curitiba, v. 6, n. 3, p. 10371-10379, 2020.

[6] GROTTO, H. Z. W. Metabolismo do ferro: uma revisão sobre os principais mecanismos envolvidos em sua homeostase. Rev. Bras. Hematol. Hemoter., v. 30, n. 5, p. 390-397, 2008.

[7] HELLER, L. Desastres de mineração e saúde pública no Brasil: lições (não) aprendidas. Cad. Saúde Pública, Rio de Janeiro, v. 35, n. 5, e 00073619, 2019.

[8] MUNIZ, D.H.F.; OLIVEIRA-FILHO, E.C. Metais pesados provenientes de rejeitos de mineração e seus efeitos sobre a saúde e o meio ambiente. Universitas: Ciências da Saúde, v. 4, n. 1 / 2, p. 83-100, 2006.

[9] PIRES, J. M. M. et al. Potencial poluidor de resíduo sólido da Samarco Mineração: estudo de caso da barragem de Germano. Sociedade de Investigações Florestais, v.27, n.3, p.393-397, 2003.

[10] SILVA, C. R.; CUNHA, F. G.; VIGLIO, E. P. Rompimento da barragem de mineração de ferro em Mariana-Minas Gerais, Brasil: impactos físico-químicos. In: III Congresso da Sociedade de Análise de Risco Latino Americana, IPT, São Paulo, 2016.

[11] SOUZA, A. K. R; MORASSUTI, C. Y.; DEUS, W. B. Poluição do ambiente por metais pesados e utilização de vegetais como bioindicadores. Acta Biomedica Brasiliensia, v. 9, n. 3, 2018.

[12] SUDRÉ, L.; PINA, R. Moradores de Brumadinho expostos à lama começam a apresentar sintomas de contaminação, Feridas da Vale, 02 de Fev. de 2019. 


\section{Capitulo 17}

\section{Avaliação da erodibilidade de solos na área urbana de João Monlevade - MG}

\section{Maísa Comar Pinhotti Aguiar \\ Jean Aparecido Viegas}

Resumo: Os processos erosivos constituem um problema geotécnico para muitos municípios brasileiros e podem ser observados em vários locais da área urbana de João Monlevade (MG). A erosão do solo depende de suas propriedades, fatores topográficos e climáticos. A erodibilidade, por sua vez, representa a capacidade do solo de resistir ao transporte pelo escoamento superficial e que seu conhecimento é indispensável. Entretanto, a caracterização da erodibilidade envolve, em geral, a utilização de métodos onerosos, diretos e que requerem muitos anos de observação, em áreas experimentais; assim, para permitir uma estimativa menos onerosa, foram desenvolvidos métodos indiretos para sua avaliação que utilizam atributos químicos e físicos do espaço de terra analisado. Nesse sentido, este artigo tem como objetivo aplicar métodos indiretos expeditos para avaliação da erodibilidade de solos na área urbana do município, uma vez que não existiam estudos sobre as condicionantes deste processo no local pesquisado. Logo, o presente trabalho se desenvolveu através de levantamentos bibliográficos, identificações preliminares de locais com a ocorrência de processos erosivos semelhantes, visitas de campo aos locais previamente identificados para coleta de dados sobre uso e ocupação do solo, seu relevo e coletas para a descrição e análise das amostras de solos. Dessa forma, considerando-se que os métodos sistemáticos de estimativa de erosão em campo são dispendiosos, a análise dos dados foi sistematizada por meio de métodos indiretos que utilizam dados de textura do solo para obtenção de um índice de erodibilidade. Posto isso, os resultados obtidos indicaram que os solos da área urbana têm potencial baixo a médio de erosão, no entanto, constatou-se que apesar do baixo potencial erosivo, a evolução desses processos pode inviabilizar o uso da área, de modo que seu conhecimento contribui para o planejamento de uso e ocupação do meio físico que respeita as suas características e limitações.

Palavras-chave: Solos, Erodibilidade, Conservação do solo, Urbanização 


\section{INTRODUÇÃO}

O solo é um elemento indispensável à vida na Terra e sua interação com a hidrosfera, organismos e clima determina a qualidade da vida no planeta. A importância dos solos como meio de preservação e promoção da vida na Terra, ocorre por intermédio do fornecimento de água e nutrientes para as plantas, do papel como suporte para edificações juntamente com outras atividades humanas e sua atuação como meio de absorção, purificação, transporte e liberação de água, como desta a Organização das Nações Unidas para Agricultura e Alimentação (FAO, 2015).

Essas propriedades, no entanto, podem ser alteradas por processos como a erosão, que constitui a remoção de uma massa de solo de um local e sua deposição em outros, acontecendo como resultado da ação de forças exógenas e a sua aceleração pela intervenção antrópica, causando, desse modo, danos irreversíveis e prejuízos de ordem econômica, social e de conservação do ecossistema (SANTOS, 2007).

Piga (2017) destaca que em áreas urbanas o processo erosivo tem se apresentado como o principal problema geotécnico enfrentado e que a sua prevenção inclui a adoção de um planejamento de uso e ocupação do solo através de um planejamento municipal que estabeleça limites para ocupação e expansão do perímetro urbano.

Bastos et al (2001) destacam que a ação erosiva acelerada da água sobre os solos urbanos é quase sempre associada à intervenção imprópria do homem no meio físico e relaciona-se às modificações da topografia original dos terrenos, concentração de aguas superficiais pela abertura de ruas, por estruturas de drenagem mal projetadas e/ou mal executadas, por redes de galerias pluviais e de esgotos lançados de forma inadequada nos talvegues receptores e ainda pela exposição de solos erodíveis à ação direta do fluxo de águas pluviais.

A erodibilidade, um dos fatores naturais intervenientes nos processos erosivos, por sua vez, é conceituada por Morgan (2005) e Demarchi \& Zimback (2014) e Bastos (2001) como a resistência do solo ao desprendimento dos materiais de sua matriz sólida, assim representando a propriedade do solo que retrata uma maior ou menor facilidade com que suas partículas são destacadas e transportadas pela ação de um agente erosivo.

Demarcki \& Zimback (2014) destacam que a erodibilidade dos solos representa, de forma direta, a suscetibilidade natural do solo frente ao potencial erosivo das chuvas e é dependente de fatores que afetam a velocidade de infiltração, permeabilidade e capacidade total de armazenamento de água do solo. Os fatores que afetam a erodibilidade são: a posição topográfica, a declividade e a quantidade de pedoturbação, mas principalmente das propriedades físicas do solo tal qual a textura do solo, a estabilidade de agregados, a resistência ao cisalhamento, a capacidade de infiltração e o teor de matéria orgânica. Assim, a importância das propriedades físicas como a estrutura, textura, permeabilidade e densidade do solo no potencial de erodibilidade é destacada por autores como Santos e Araújo (2018), Silva et al (1999), Lima et al (2016) e Corrêa et al (2015).

Pedro e Lorandi (2004) destacam que, historicamente, o processo de urbanização desencadeia processos de degradação do meio físico que por sua vez implicarão em degradação ambiental e dessa forma o meio físico e em especial o solo tem papel relevante na determinação das limitações e aptidões de uma determinada área para uso e ocupação pelo homem. Nessa perspectiva, Brito (2012) coloca que a erosão não é um problema somente do meio físico, mas também um problema social e econômico, na medida que a degradação do solo gera problemas que devem ser geridos pela municipalidade.

Considerando a relevância que os processos erosivos apresentam na ocupação urbana, segundo Salomão et al (2012), o diagnóstico juntamente com a adoção de medidas efetivas de controle preventivo e corretivo dos processos erosivos, devem ser realizados levando-se em conta o entendimento dos mecanismos relacionados com a dinâmica do funcionamento.

Verifica-se, portanto, que o conhecimento do meio físico e de seus potenciais processos de degradação ambiental são indispensáveis para avaliar as potencialidades e limitações ambientais de uma dada região ou município, como é o caso de João Monlevade, cidade cujo Plano Diretor (Prefeitura, 1996) não permite a edificação em áreas onde as condições geológicas não aconselham essa implantação, o que reforça a importância de se conhecer as características do meio urbano devido às limitações estabelecidas por essas no planejamento e uso da terra. 


\section{OBJETIVO}

Este trabalho teve como propósito principal caracterizar a erodibilidade de solos na área urbana de João Monlevade (MG) mediante métodos indiretos e de baixo custo, que utilizam a textura do solo e apresentam uma execução mais rápida que outras medições sistemáticas da erosão em campo exigidas em métodos diretos de avaliação.

Essa caracterização foi motivada pela ocorrência de processos erosivos em vários locais na cidade e a eventual limitação que elas poderiam representar para a ocupação dessas áreas, bem como pela necessidade de conhecer, preliminarmente, os mecanismos que atuam na origem do processo erosivo.

\section{METODOLOGIA}

\subsection{CARACTERIZAÇÃO DA ÁREA DE ESTUDO}

O município de João Monlevade possui território de 99,16 $\mathrm{km}^{2}$ e localiza-se no Centro Leste de Minas Gerais, dentro do contexto geológico da região nordeste do Quadrilátero Ferrífero. A geologia regional é constituída por um substrato geológico constituído por rochas granitóides e metamórficas de alto grau representadas por quartzitos, anfibolitos, xistos de acordo com CPRM (2000).

Conforme Martins et al (2018), a área encontra-se de acordo com a classificação de Koppen em domínio climático Aw, um clima tropical, com inverno seco, apresentando estação chuvosa no verão, de novembro a abril, e nítida estação seca no inverno, de maio a outubro. A temperatura média do mês mais frio é geralmente inferior a $20^{\circ} \mathrm{C}$ e as precipitações são superiores a $750 \mathrm{~mm}$ anuais, podendo atingir $1400 \mathrm{~mm}$, sendo que esses dados podem ser observados na Figura 1.

Figura 1- Dados climatológicos de João Monlevade no período de 1961 a 1990

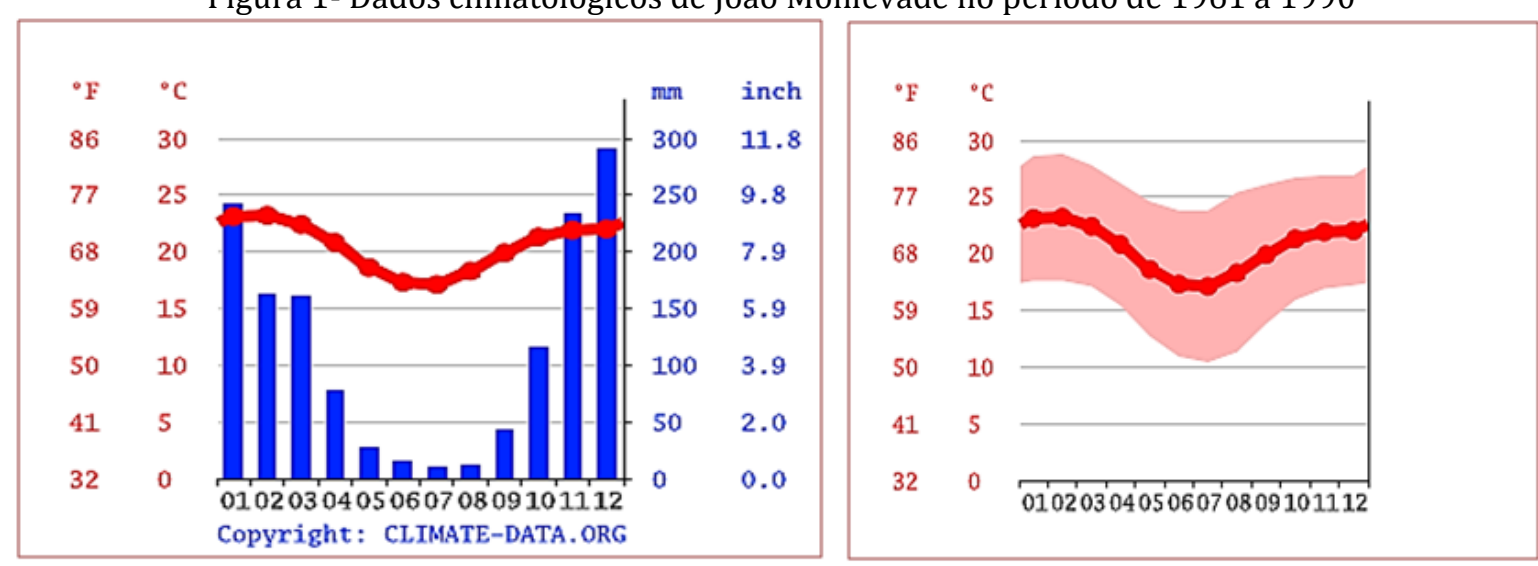

Fonte: https://en.climate-data.org/south-america/brazil/minas-gerais/joao-monlevade-24904/

O município em questão insere-se em relevo de domínio de mares de morros e montanhas com altitudes que variam de $600 \mathrm{~m}$ a $1330 \mathrm{~m}$, uma amplitude topográfica de cerca de $700 \mathrm{~m}$, como mostra o mapa hipsométrico da Figura 2, elaborado no software livre QGIS 3.10. 
Figura 2- Mapa hipsométrico do município de João Monlevade (MG)

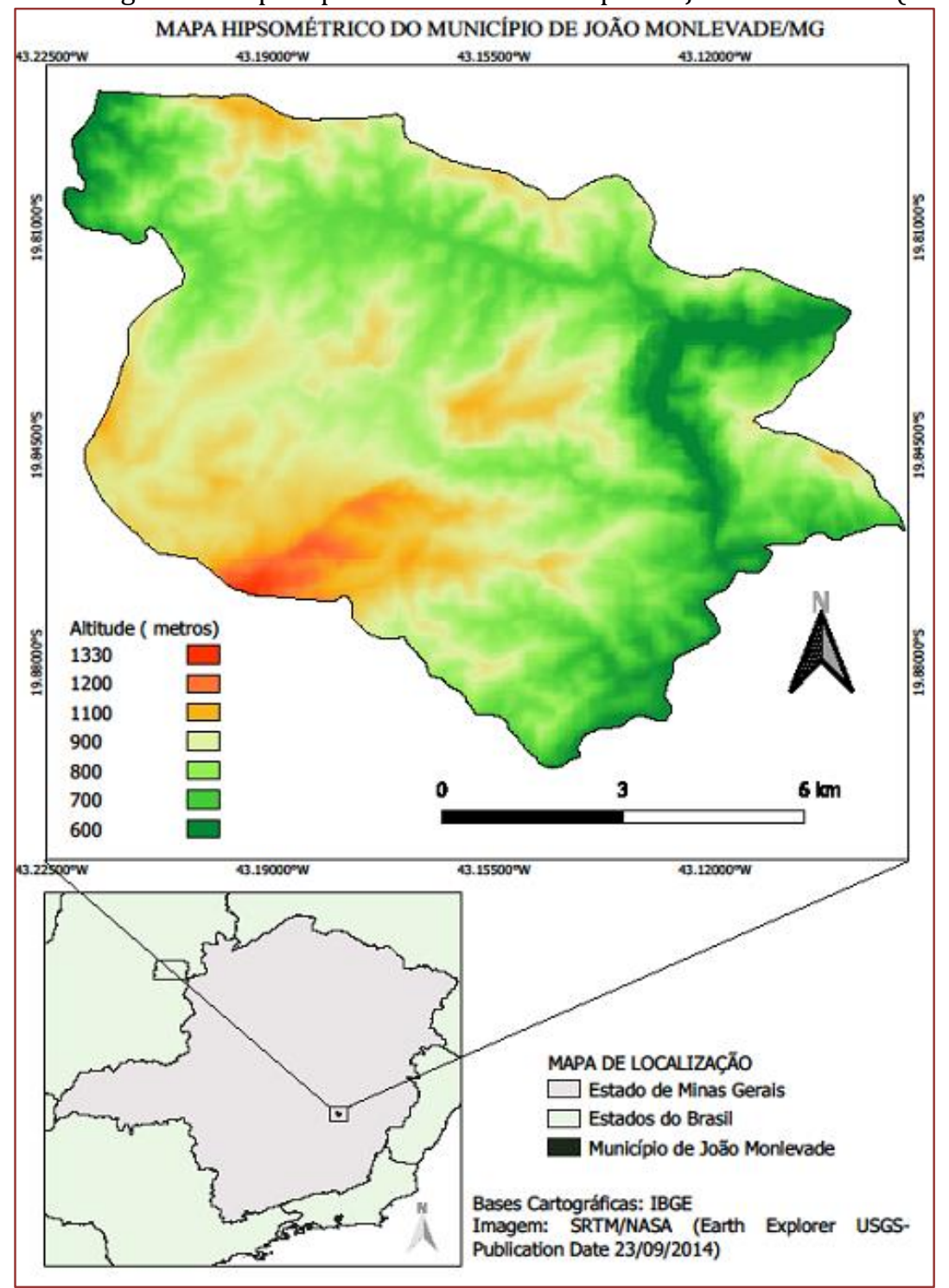

Fonte: Autores

\subsection{ETAPAS DE DESENVOLVIMENTO DO TRABALHO DE PESQUISA}

A pesquisa desenvolvida é, quanto à sua natureza, uma pesquisa aplicada pois envolve o estudo da erosão na área urbana de João Monlevade (MG). Quanto aos objetivos, ela é explicativa, pois busca analisar o fenômeno da erosão na área urbana de João Monlevade através da determinação do índice de erodibilidade (PRODANOV e FREITAS, 2013).

Seu desenvolvimento foi pautado pelas etapas indicadas Figura 3.

Figura 3- Etapas de desenvolvimento do trabalho

\begin{tabular}{|c|c|c|c|c|c|}
\hline $\begin{array}{l}\text { 1- Revisão } \\
\text { bibliográfica }\end{array}$ & $\begin{array}{c}2- \\
\text { Identificação } \\
\text { dos locais } \\
\text { com erosão } \\
\text { na área }\end{array}$ & $\begin{array}{l}\text { 3-Visita de } \\
\text { campo }\end{array}$ & $\begin{array}{l}\text { 4- Descrição } \\
\text { do local } \\
\text { visitado } \\
\text { Documentação } \\
\text { fotográfica }\end{array}$ & $\begin{array}{l}\text { 5- Coleta de } \\
\text { amostras } \\
\text { para } \\
\text { ensaios de } \\
\text { laboratório }\end{array}$ & $\begin{array}{l}\text { 6-Análise } \\
\text { granulométrica } \\
\text { e calculo da } \\
\text { erodibilidade }\end{array}$ \\
\hline
\end{tabular}


A identificação dos locais com processos erosivos instalados foi realizada a partir de imagens do Google Earth e dos locais identificados, foram visitados inicialmente cinco (05), sendo que alguns não puderam ser estudados em virtude da dificuldade de acesso (falta de estrada/caminhos ou relevo desfavorável).

As visitas de campo possibilitaram a observação in loco das inter-relações entre o solo e outros aspectos do meio, como o relevo e uso e ocupação do solo bem como a coleta de amostras de solo para análises em laboratório. As amostras foram coletadas de dois horizontes distintos identificados em campo, como mostra a Figura 4- um superficial com espessura de $30-50 \mathrm{~cm}$ caracterizado por cor marrom avermelhada e o outro subjacente, de cor rosada.

Figura 4 Corte onde se observa os dois horizontes de solo amostrados nas proximidades da Agência Fiat em João Monlevade

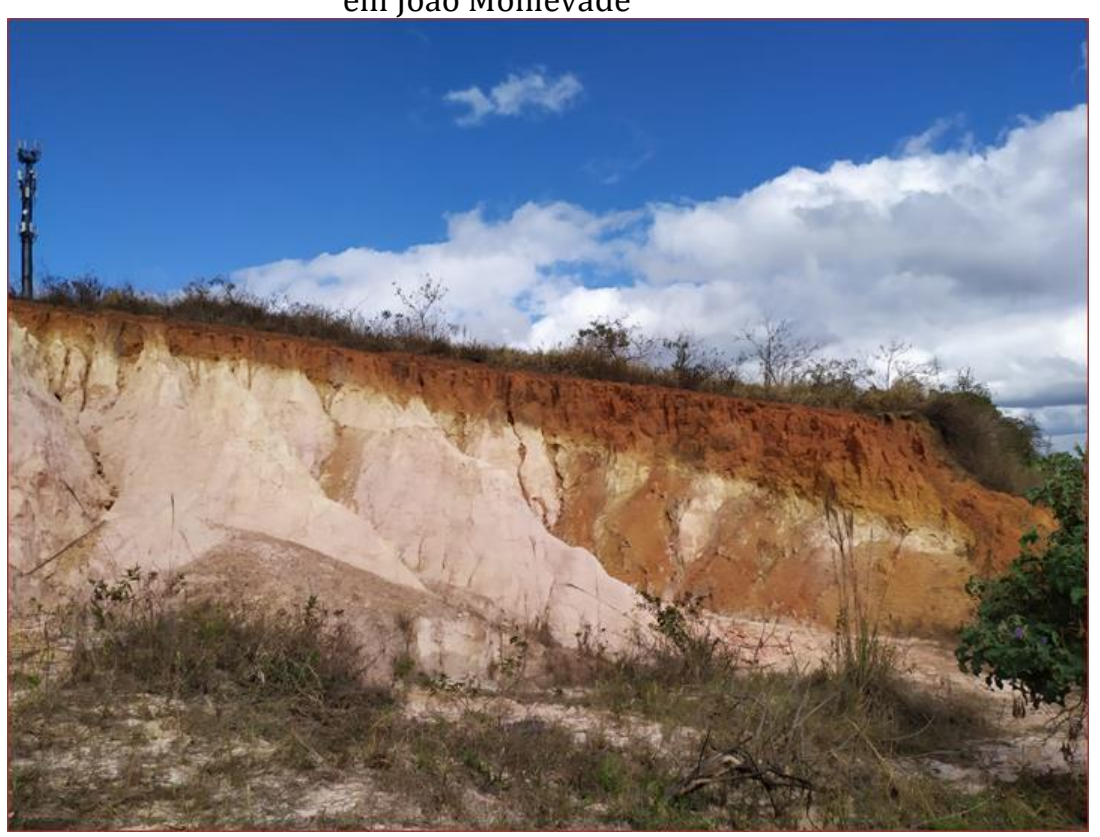

Fonte: Autores (2020)

A coleta do solo foi feita com trado concha e as amostras enviadas para análises granulométricas no Laboratório de Física do Solo do Instituto Agronômico de Campinas (IAC).

A partir dos dados da granulometria completa, efetuou-se o cálculo do índice de erodibilidade (K) de acordo a equação 1 da metodologia proposta por Mannigel et al (2002).

$$
K=\frac{\left[\frac{\% \text { areia } \% \text { silte }}{\% \text { argila }}\right]}{100}
$$

Onde $\mathbf{K}$ representa o fator erodibilidade do solo dado em (t.ha.h/ha.MJ.mm;), e a \%areia, \%silte e \%argila representaram as porcentagens das respectivas frações obtidas a partir da análise granulométrica.

\section{RESULTADOS E DISCUSSÃO}

As visitas de campo nos locais inicialmente identificados e suas análises granulométricas permitiram caracterizar o horizonte superficial de cor avermelhada com textura muito-argilosa a argilosa, com teores de argila variando de $79,7 \%$ a 25,6\%, já o horizonte subjacente (horizonte 2) possui textura arenosa com fração areia total que varia entre entre $56,1 \%$ a $21,1 \%$, textura essa que possibilita maior desagregação do solo. 
Os fatores de erodibilidade $(\mathrm{k})$ determinados para o horizonte superficial resultaram em valores que variaram de 0,0011 a 00,0072 t.ha.h/ ha.MJ.mm enquanto o solo subjacente apresentou fatores de erodibilidade de 0,0254 a 0,029 t.ha.h/ ha.MJ.mm.

Apesar da variação de valores apresentada pelos dois horizontes, a erodibilidade em ambos pode ser classificada como baixa, de acordo com Foster et. al (1981); já para o segundo Mannigel et al (2002), que propôs um número maior de classes de erodibilidade, o fator de erodibilidade do horizonte de textura arenosa seria classificado como médio (valores de K entre 0,0150 e 0,0300 t.ha.h/ha.MJ.mm) e o horizonte superficial como baixo a muito baixo.

Esse resultado condiz com o que foi observado em campo, pois o processo erosivo desenvolve-se de forma mais intensa no horizonte de textura arenosa (horizonte B) que no horizonte superficial. Cumpre ressaltar que essa sequência é encontrada usualmente nas áreas de maior altitude, enquanto nas porções de menor altitude predominam, de modo geral, os materiais de textura arenosa

Considerando-se que a erosão do solo depende também das condições pluviométricas e do relevo, esses parâmetros serão incorporados à análise dos processos erosivos no local em questão, possibilitando também a estimativa futura da Erosividade do solo.

\section{CONSIDERAÇÕES FINAIS}

Em suma, este trabalho, que ainda se encontra em desenvolvimento, objetiva verificar a erodibilidade de solos na área urbana de João Monlevade mediante a utilização de métodos indiretos, menos custosos e de rápida execução, como é o caso da análise granulométrica (textura do solo). Nesse contexto, a verificação da erodibilidade e dos fatores que a influenciam são importantes, tendo em vista a existência de processos erosivos aliados a topografia movimentada e ao clima do município, fatores que podem comprometer o uso e ocupação urbana.

Consequentemente, os resultados obtidos na análise preliminar dos dados do fator de erodibilidade do local corroboram a tendência à erosão observada em campo e, à vista disso, fica demonstrada a necessidade de maior compreensão dos processos que atuam no meio físico e suas implicações para o planejamento do uso e ocupação do solo, tanto em áreas urbanas quanto rurais, uma vez que a degradação ambiental compromete a disponibilidade de recursos para as atividades humanas em todos os aspectos, exigindo recursos, muitas vezes, vultosos, para sua possível recuperação.

\section{REFERÊNCIAS}

[1] BASTOS, Cezar Augusto, MILITITSKY, J. e GEHLING, W. Proposta metodológica para avaliação geotécnica da erodibilidade de solos residuais não saturados. VII Simpósio Nacional de Controle de Erosão Goiânia (GO), 03 a 06 de maio de 2001

[2] BRITO, Annanery de Oliveira. Estudos da erosão urbana no ambiente urbano, visando planejamento e controle ambiental no Distrito Federal. Dissertação (Mestrado) apresentada ao Departamento de Engenharia Florestal da Faculdade de Tecnologia- Universidade de Brasília, 2012, 78 p

[3] CPRM-Companhia de Pesquisa de Recursos Minerais. Itabira: folha SE.23-Z-D-IV: estado de Minas Gerais. Brasília: CPRM, Programa Levantamentos Geológicos Básicos do Brasil, 2000. Disponível em http://rigeo.cprm.gov.br/jspui/handle/doc/5662, acesso em 02/06/2020

[4] CORRÊA, Edvania Aparecida, Moraes, I. C., Pinto, S. dos A. F. Estimativa da erodibilidade e tolerância de perdas de solo na região Centro Leste Paulista. São Paulo, UNESP, Geociências, v. 34, n. 4, p.848-860, 2015. Disponível em https://www.revistageociencias.com.br/geociencias-arquivos/34/volume34_4_files/34-4-artigo-08.pdf, acesso em $10 / 12 / 2020$

[5] DEMARCHI, Julio Cesar \& ZIMBACK, Célia Regina Lopes. Mapeamento, erodibilidade e tolerância de perda de solo na sub-bacia do Ribeirão das Perobas. Energia na Agricultura, Botucatu, v. 29, n. 2, p. 102-114, abril-junho 2014. Disponível em http://revistas.fca.unesp.br/index.php/energia/article/view/841, acesso em 20/06/2020

[6] FAO-Food AND Agriculture Foundation of united nations Status of the World's Soil Resources: Main Report, 2015. Disponível em http://www.fao.org/documents/card/en/c/c6814873-efc3-41db-b7d3-2081a10ede50/, acesso em $18 / 06 / 2020$

[7] FOSTER, G. R. et al. Conversion of the universal soil loss equation to SI metric units. Journal of Soil Water Conservation., $\quad$ Baltimore, $\quad$ v.36, $\quad$ p.355-359, $1981 . \quad$ Disponível https://www.tucson.ars.ag.gov/unit/publications/PDFfiles/361.pdf, acesso em 02/02/2020 
[8] LIMA, César Gustavo da Rocha; CARVAlHO, M.de P.; Souza, A.; Costa, N.R.; Montanari, R. Influência de atributos químicos na erodibilidade e tolerância de perda de solo na Baica Hidrográfica do Baixo São José dos Dourados. São Paulo, UNESP, Geociências, v. 35, n. 1, p.63-76 , 2016 Disponível em https://www.revistageociencias.com.br/geociencias-arquivos/35/volume35_1_files/35-1-artigo-05.pdf

MANNIGEL, Anny Rosi; Passos e Carvalho, M., Moreti, D., Medeiros, L.R. Fator erodibilidade e tolerância de perda dos solos do Estado de São Paulo. Acta Scientiarum, Maringá, v. 24, n. 5, p. 1335-1340, 2002. Disponível em http://periodicos.uem.br/ojs/index.php/ActaSciAgron/article/view/2374, acesso em 18/06/2020

[9] MARTINS, Fabrina Bolzan, Gonzaga, G., Santos, D. F dos, Reboita, M.S. Classificação climática de Koppen e de Thornthwaite para Minas Gerais: Cenário atual e projeções futuras. Revista Brasileira de Climatologia, Ano 14 - Edição Especial Dossiê Climatologia de Minas Gerais - NOV 2018, Disponível em https://www.researchgate.net/publication/328913917_Classificacao_climatica_de_Koppen_e_de_Thornthwaite_para_ Minas_Gerais_Cenario_atual_e_projecoes_futuras, acesso em 02/12/2020

[10] MORGAN, Royston Philip Charles. Soil erosion and conservation / R. P. C. Morgan. 2005, 3rd ed. p. Disponível em nvgaos.nl>Morgan_2005_Soil_Erosion_and_Conservation, acesso em 01/07/2020

[11] PEDRO, F. G.; LORANDI, R. POTENCIAL NATURAL DE EROSÃO NA ÁREA PERIURBANA DE SÃO CARLOSSP. Revista Brasileira de Cartografia, v. 56, n. $1, \quad 11 . \quad$ Disponível em http://www.seer.ufu.br/index.php/revistabrasileiracartografia/article/view/43499, acesso 27/12/2020

[12] PIGA, Fabiana Geovanna. Modelagem ambiental de áreas degradadas por processos erosivos, com vista ao planejamento ambiental-São Pedro e Santa Maria da Serra/SP. 2017. 128 f. Dissertação (Mestrado em Ciências Ambientais) - Https://repositorio.ufscar.br/handle/ufscar/9509, [S. l.], 2017. Disponível em: https://repositorio.ufscar.br/handle/ufscar/9509. Acesso em: 10 jul. 2020.

[13] PREFEITURA, Municipal de João Monlevade. Lei № 1.357, de 13 de novembro de 1996. Dispõe sobre o parcelamento do solo urbano no município de João Monlevade e dá outras providências.

[14] PRODANOV, Cleber Cristiano e FREITAS, Ernani Cesar. Metodologia do trabalho científico [recurso eletrônico] : métodos e técnicas da pesquisa e do trabalho acadêmico. - 2. ed. - Novo Hamburgo: Feevale, 2013.

[15] SALOMÃO, Fernando Ximenes de Tavares; CANIL, Kátia; RODRIGUES, Samantha Paulo. Exemplo de aplicação da geologia de engenharia no controle preventivo e corretivo dos processos erosivos. Revista Brasileira de Geologia de Engenharia e Ambiental, v. 2, n. 2, p. 39-56, 2012.Disponível em https://www.abge.org.br/volume-2-no-2, acesso em $20 / 12 / 2020$

[16] SANTOS, R. E. S.; ARAUJO, R. C.. Análise da adequabilidade de indicadores d/e erodibilidade de solos baseados em parâmetros geotécnicos. Revista Ibero Americana de Ciências Ambientais, v.9, n.2, p.115-126, 2018. DOI: http://doi.org/10.6008/CBPC2179- 6858.2018.002.0011

[17] SANTOS, Rozely Ferreira dos Santos (organizadora). Vulnerabilidade Ambiental - Brasília: MMA, 2007.192 p. : il. color.

[18] SILVA, Marx Leandro Naves, Curi, N., Ferreira, M. M., Lima, J. M. de, Ferreira, D. F. Proposição de modelos para estimativa da erodibilidade de latossolos brasileiros. Pesq. agropec. bras., Brasília, v.34, n.12, p.2287-2298, dez. 1999

[19] TORRES, FillipeTamiozzo Pereira et al. A susceptibilidade à erosão como subsídio ao planejamento urbano: estudo de caso do município de Ubá - MG. Revista Agrogeoambiental - v. 6, n. 1 - Abril 2014. Disponível em https://www.academia.edu/41172801/A_susceptibilidade_\%C3\%A0_eros\%C3\%A3o_como_subs\%C3\%ADdio_ao_pla nejamento_urbano_estudo_de_caso_do_munic\%C3\%ADpio_de_Ub\%C3\%A1_MG, acesso em 10/12/2020 


\title{
Capítulo 18
}

\section{Análise de risco e susceptibilidade a erosão com auxílio do Sensoriamento Remoto}

\author{
Diogo Caio Rocha Amorim \\ Abílio Silva Nunes \\ Eula Paula Oliveira Silva \\ Guilherme Coelho Araujo \\ Jhenifer Stefany Eloi de Paulo \\ Lorena Lopes Gonçalves
}

Resumo : Este trabalho apresenta como objetivo principal o mapeamento por zoneamento e classificação de áreas de risco ambiental no município de Betim- MG, enfatizando os Bairros Duque de Caxias e Jardim Teresópolis. Para o levantamento das áreas que possuem risco ambiental, geológico e pedológico do município de Betim-Mg, faz necessária a utilização da modelagem aplicada ao Sensoriamento Remoto e Geoprocessamento, modulados pelo Sistema de informações Geográficas (SIG). Como resultado principal para os dois bairros obtiveram-se mapas de várias categorias de análise, tais como: Altimetria, Declividade, Mancha urbana, Mancha Vegetal, Drenagem, Pluviometria e Tipo de Solo. 0 bairro Jardim Teresópolis possui uma área total de 1.9 $\mathrm{km}^{2}$ e obteve $0.02 \mathrm{~km}^{2}$ de áreas suscetíveis a deslizamentos de massa, isso é o equivalente à $1,05 \%$ da área total. Já o bairro Duque de Caxias o mapa abaixo mostra uma área total de $1.43 \mathrm{~km}^{2}$ com $0.407 \mathrm{~km}^{2}$ de áreas suscetíveis a deslizamentos de massa, isso é o equivalente a $28,46 \%$ da área total.

Palavras-chave: Solo; SIG; Geoprocessamento; Cobertura Vegetal; Precipitação 


\section{INTRODUÇÃO}

A grande utilização do uso do solo no que envolve as atividades humanas e urbanas nas cidades, em sua maioria contempla a eliminação da cobertura vegetal em detrimento às construções urbanas formais e informais, o que promove uma série de processos de erosão dos solos.

Segundo DENGSHENG LU et tal, 2006 o grande aumento da população associado a expansão urbana, resulta na diminuição de terras agrícolas e áreas florestais, o que gera uma grande pressão sobre os recursos naturais e as condições ambientais.

0 processo de ocupação acelerada com diminuição de áreas de florestas ocorre de forma constante em nosso país e ficou fortemente evidenciado com as chuvas atípicas em toda região metropolitana de Belo Horizonte - MG nos meses de Janeiro e Fevereiro de 2020, onde podemos destacar o município de Betim, ocasionando uma constante erosão hídrica de superfície com a remoção das camadas superficiais dos solos e sua vegetação.

A seguir o mapa de localização da cidade de Betim - MG, apresentando sua ocupação urbana, fortemente indicada no sentido leste - oeste e também sua vegetação, que circula sua ocupação

Figura 1: Mapa da cidade de Betim

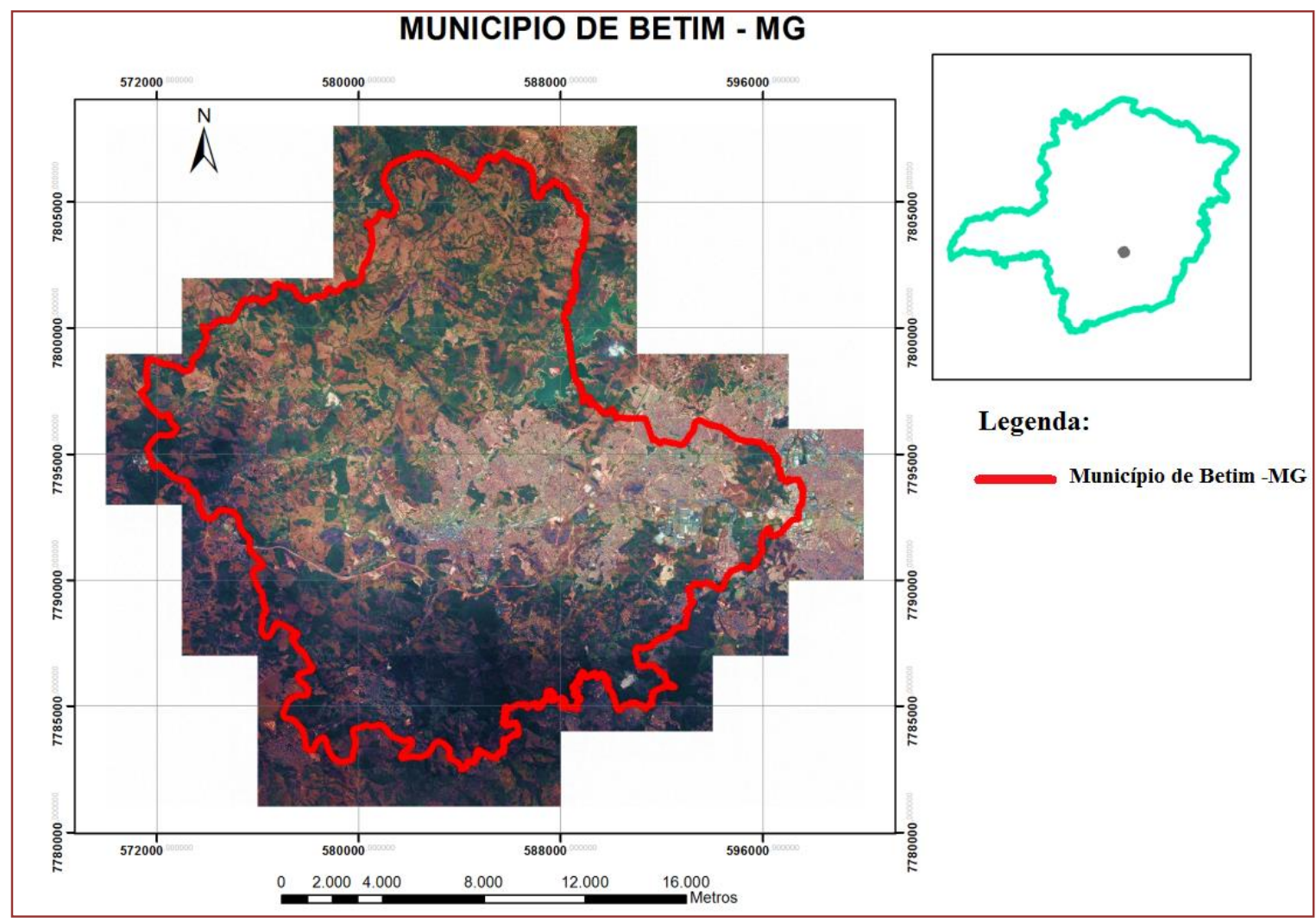

Fonte: Autoria Própria

O resultado do processo de ocupação é o alagamento constante de vias públicas localizadas em áreas de topografia mais baixa, além de erosões em áreas onde a vegetação foi retirada, principalmente nas regiões mais carentes do município dando lugar a construções precárias, oque as tornam susceptíveis ao desmoronamento e rupturas.

Para WENG, 2012 a utilização do Sensoriamento Remoto aliado ao Geoprocessamento permite realizar e quantificar superfícies urbanas impermeáveis e entender os impactos espaciais, geométricos e espectrais, associados à substituição da camada vegetal para as construções urbanas.

Este presente trabalho apresenta como objetivo principal o mapeamento por zoneamento e classificação de áreas de risco ambiental no município de Betim- MG, com foco nos Bairros Duque de Caxias e Jardim Teresópolis. Esses bairros foram os mais atingidos pelas fortes chuvas ocorridas nos meses de Janeiro e Fevereiro de 2020. 0 trabalho visa entrar em acordo com os Objetivos de Desenvolvimento Sustentável do 
Milênio da ONU enfatizando o objetivo 11 quex' tende a tornar as cidades e os assentamentos humanos inclusivos, seguros, resilientes e sustentáveis (ONU,2015).

\section{METODOLOGIA}

Para o levantamento das áreas que possuem risco ambiental, geológico e pedológico do município de Betim-Mg, faz necessária a utilização da modelagem aplicada ao Sensoriamento Remoto e Geoprocessamento, modulados pelo Sistema de informações Geográficas (SIG).

A base de dados utilizada é formada e captada pela distribuição de imagens de satélites, Levantamentos Geológicos, Pedológicos, Hídricos, Pluviométricos, todos disponibilizados de forma atualizada por órgãos governamentais, tais como Prefeitura Municipal de Betim, CPRM (Serviço Geológico do Brasil), INMET (Instituto Meteorológico do Brasil), SISEMA-MG (Sistema Estadual de Meio Ambiente e Recursos Hídricos de Minas Gerais), entre outros.

Para o levantamento, foram determinadas variáveis, tais como: Altimetria, Declividade, Mancha urbana, Mancha Vegetal, Drenagem, Pluviometria e Tipo de Solo. Todas as classes para cada variável foram padronizadas para uma escala de 0 a 5 pontos de acordo com o risco que direcionam para a ocorrência de erosões, sendo 0 (zero) para risco nulo, 1 (um) para risco baixo, 2 (dois) para risco moderado, 3 (três) para risco alto, 4 (quatro) para risco muito alto e 5 (cinco) para risco extremo.

\subsection{ALTIMETRIA}

A definição de altimetria consiste no estudo dos métodos e ferramentas de utilização para determinar a variação que ocorre no relevo do terreno.

Tabela 1 - Classificação de risco quanto a Altimetria

\begin{tabular}{ccc}
\hline ALTIMETRIA & RISCO & PONTUAÇÃO \\
\hline Até $600 \mathrm{~m}$ & Extremo & 5 \\
$600-900 \mathrm{~m}$ & Alto & 4 \\
$900-1200 \mathrm{~m}$ & Médio & 3 \\
$1200-1500 \mathrm{~m}$ & Moderado & 2 \\
Acima de 1500 & Baixo & 1 \\
\hline
\end{tabular}

\subsection{DECLIVIDADE}

O relevo tem influência sobre os fatores meteorológicos e hidrológicos, pois a velocidade do escoamento superficial é determinada pela declividade do terreno. Deste modo, o grau de declive é um dos fatores mais importantes no processo erosivo, pois do grau de declive depende diretamente o volume e a velocidade das enxurradas que sobre ele escorrem, que em princípio, quanto maior o comprimento de rampa mais enxurrada se acumula e maior energia resultante se traduz por uma erosão maior.

Tabela 2 - Classificação de risco quanto a Declividade

\begin{tabular}{ccc}
\hline DECLIVIDADE $(\%)$ & RISCO & PONTUAÇÃO \\
\hline Até $15 \%$ & Baixo & 1 \\
$16 \%-25 \%$ & Moderado & 2 \\
$26 \%-35 \%$ & Médio & 3 \\
$36 \%-45 \%$ & Alto & 4 \\
Acima de $45 \%$ & Extremo & 5 \\
\hline
\end{tabular}




\subsection{MANCHA URBANA}

A relação da mancha urbana com o processo erosivo induz que a retirada da camada vegetal para dar lugar ao forte adensamento urbano contribui de forma contundente um processo erosivo acelerado.

Tabela 3 - Classificação de risco quanto a Mancha Urbana

\begin{tabular}{ccc}
\hline MANCHA URBANA & RISCO & PONTUAÇÃO \\
\hline Fortemente adensado & Extremo & 5 \\
Pouco adensado & Médio & 3 \\
Sem Adensamento & Baixo & 1 \\
\hline
\end{tabular}

\subsection{MANCHA VEGETAL}

A mancha vegetal leva em consideração o quantitativo de árvores e sua contribuição para a movimentação de massas. Essa movimentação está relacionada diretamente com o percentual de infiltração de água precipitada no solo, ou seja, quanto mais árvores em um determinado local, maior será o percentual de infiltração e consequentemente haverá menos erosões.

Tabela 4 - Classificação de risco quanto a Mancha Vegetaç

\begin{tabular}{ccc}
\hline MANCHA VEGETAL & RISCO & PONTUAÇÃO \\
\hline Árvores de Grande Porte & Baixo & 1 \\
Árvores de Médio Porte & Moderado & 2 \\
Árvores de Pequeno Portє & Médio & 3 \\
Vegetação Rasteira & Extremo & 5 \\
\hline
\end{tabular}

\subsection{TIPO DE SOLO}

A classificação dos tipos de solo leva em consideração os três tipos solos encontrados no município de Betim (Latossolo, Cambissolo, Argissolo).

Tabela 5 - Classificação de risco quanto ao Tipo de Solo

\begin{tabular}{ccc}
\hline TIPO DE SOLO & RISCO & PONTUAÇÃO \\
\hline Latossolo & Baixo & 1 \\
Argissolo & Moderado & 2 \\
Cambissolo & Alto & 4 \\
\hline
\end{tabular}

\subsection{DRENAGEM}

As drenagens fluviais quando respeitada os seus limites de conservação apresentam um risco moderado.

Tabela 6 - Classificação de risco quanto ao Tipo de Drenagem

\begin{tabular}{ccc}
\hline DRENAGEM & RISCO & PONTUAÇÃO \\
\hline Pluvial & Extremo & 5 \\
Fluvial & Moderado & 2 \\
\hline
\end{tabular}




\subsection{PRECIPITAÇÃO}

A intensidade das precipitações pode ser um fator fundamental para acelerar os níveis de saturação de um solo, contribuindo de forma imprevisível para o processo erosivo de uma região.

Tabela 07 - Classificação de risco quanto ao Tipo de Pluviometria

\begin{tabular}{ccc}
\hline PLUVIOMETRIA $(\mathrm{mm} / \mathrm{mês})$ & RISCO & PONTUAÇÃO \\
\hline $0-50 \mathrm{~mm}$ & Muito Baixo & 0 \\
$51-150 \mathrm{~mm}$ & Baixo & 1 \\
$151-200 \mathrm{~mm}$ & Moderado & 2 \\
$201-250 \mathrm{~mm}$ & Médio & 3 \\
$251-350 \mathrm{~mm}$ & Alto & 4 \\
Acima de $350 \mathrm{~mm}$ & Extremo & 5 \\
\hline
\end{tabular}

\section{RESULTADOS E DISCUSSÕES}

\subsection{BAIRRO JARDIM TERESÓPOLIS}

\subsubsection{DECLIVIDADE}

Figura 02: Declividade Jardim Teresópolis

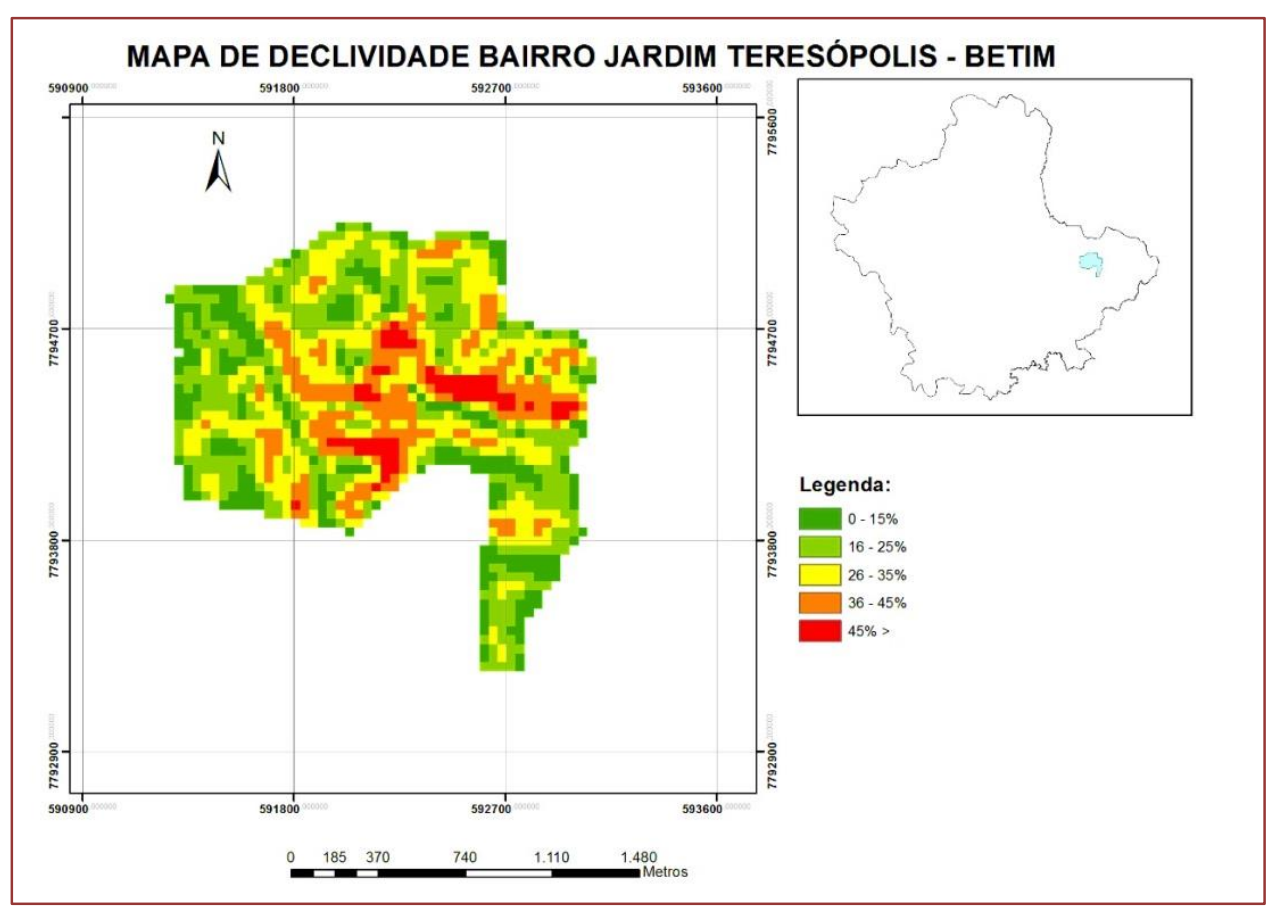

Fonte: Autoria Própria

Ao analisar o mapa de declividade do bairro Jardim Teresópolis pode-se inferir que o fator declividade influi em situações de deslizamentos, pois onde o mapa apresenta índices de $45 \%$ ou mais de declividade representa alguns pontos que já sofreram com deslizamentos, como o ponto localizado no Beco Fagundes. Algo que é majorado pela redução das áreas verdes e permeáveis, como é o caso do Bairro. 


\subsubsection{MANCHA DE VEGETAÇÃO}

Figura 03: Mancha de Vegetação Jardim Teresópolis

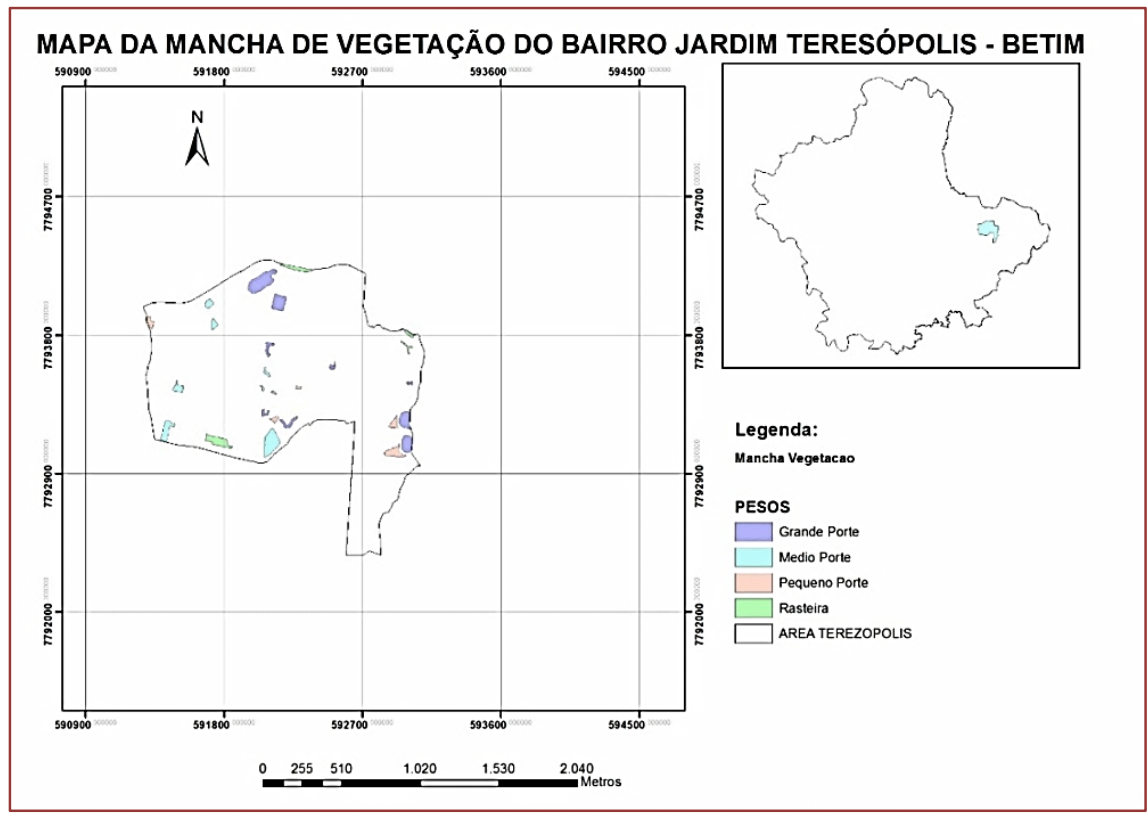

Fonte: Autoria Própria

Após analisar a mancha de vegetação no Bairro Jardim Teresópolis, pode-se concluir que as regiões onde a maior concentração da população e menor vegetação tem uma tendência maior e natural, para ocorrência de deslizamentos. Toda a vegetação restante da região se encontra localizada nas regiões de médio e baixo declívio, onde a possiblidade de ocorrência de deslizamento é menor.

Os desmatamentos e ocupações irregulares em regiões de alta declividade são considerados fatores de risco para que tais problemas ocorram nessas regiões.

Apesar dos deslizamentos serem fenômenos naturais os mesmos pode ocorrer mesmo em áreas onde a vegetação não tenha sofrido interferência do homem; porém a vegetação pode ajudar a minimizar os impactos provocados pelas chuvas, já que as raízes das vegetações ajudam na estabilidade do solo.

\subsubsection{MANCHA URBANA}

Figura 04: Mancha Urbana Jardim Teresópolis

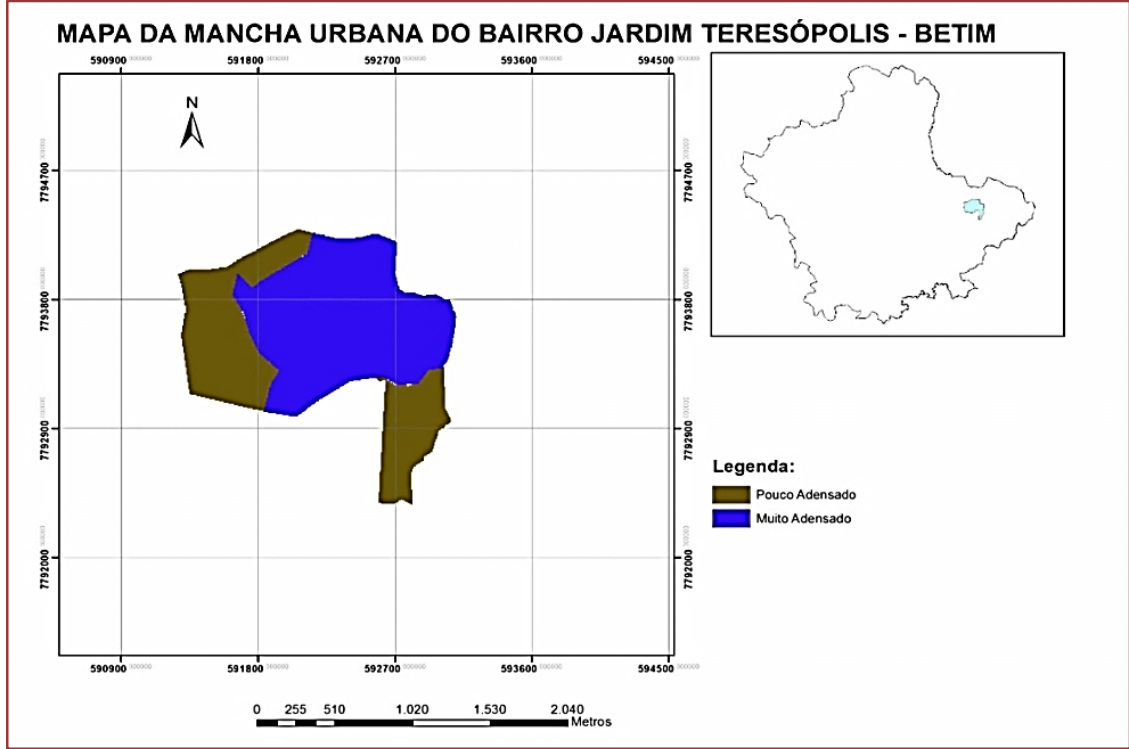

Fonte: Autoria Própria 
Como podemos analisar neste mapa podem ser verificados os dados de mancha urbana no Bairro Jardim Teresópolis, onde as áreas de cor marrom são as áreas pouco adensadas e em azul as áreas mais adensadas. Podemos inferir com este mapa que a população do bairro está mais concentrada na área central do bairro Jardim Teresópolis, já mais próximo da Fiat e na região Oeste do bairro a população está menos concentrada.

\subsubsection{ALTIMETRIA}

Figura 05: Altimetria Jardim Teresópolis

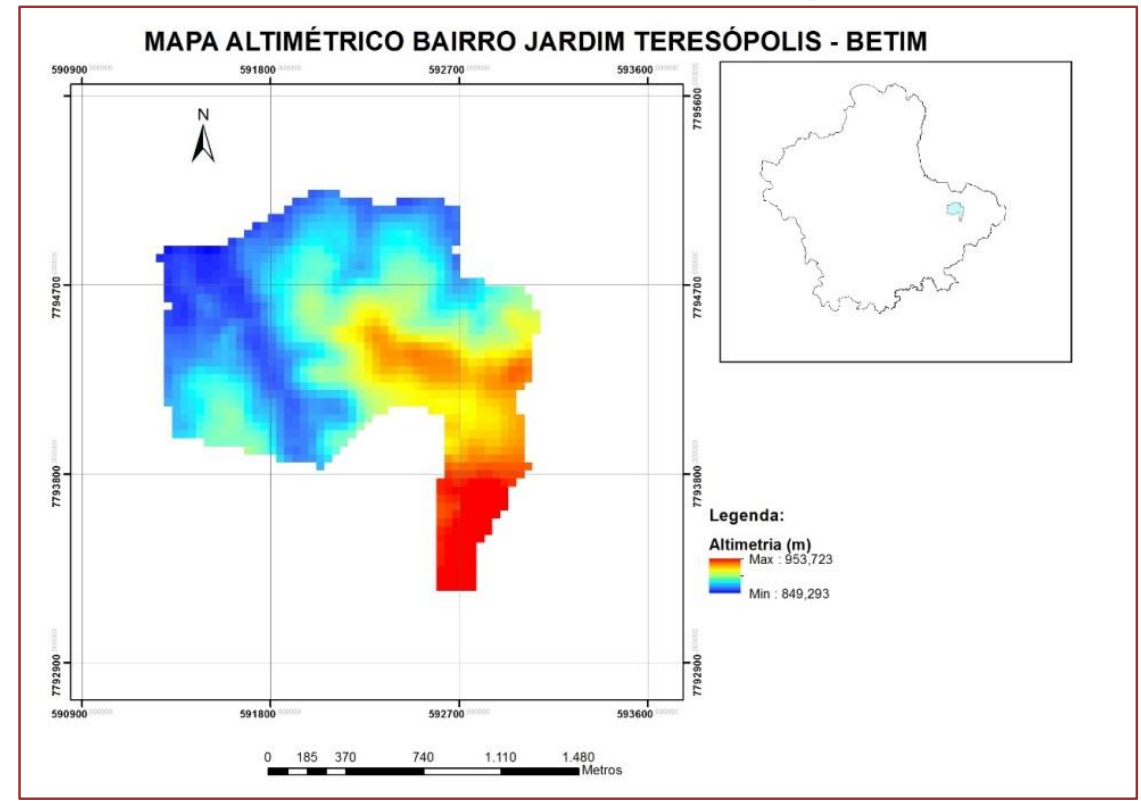

Fonte: Autoria Própria

Através desse mapa conseguimos analisar os pontos mais altos e baixos do Bairro Jardim Teresópolis, onde as áreas mais altas estão destacadas com as cores laranja e vermelho e as áreas mais baixas estão de azul e verde. Podemos inferir com esse mapa que os pontos mais altos estão localizados na entrada do Bairro Jardim Teresópolis e os mais baixos estão localizadas no Centro-Oeste do Bairro.

\subsubsection{DRENAGEM}

Figura 06: Drenagem Jardim Teresópolis

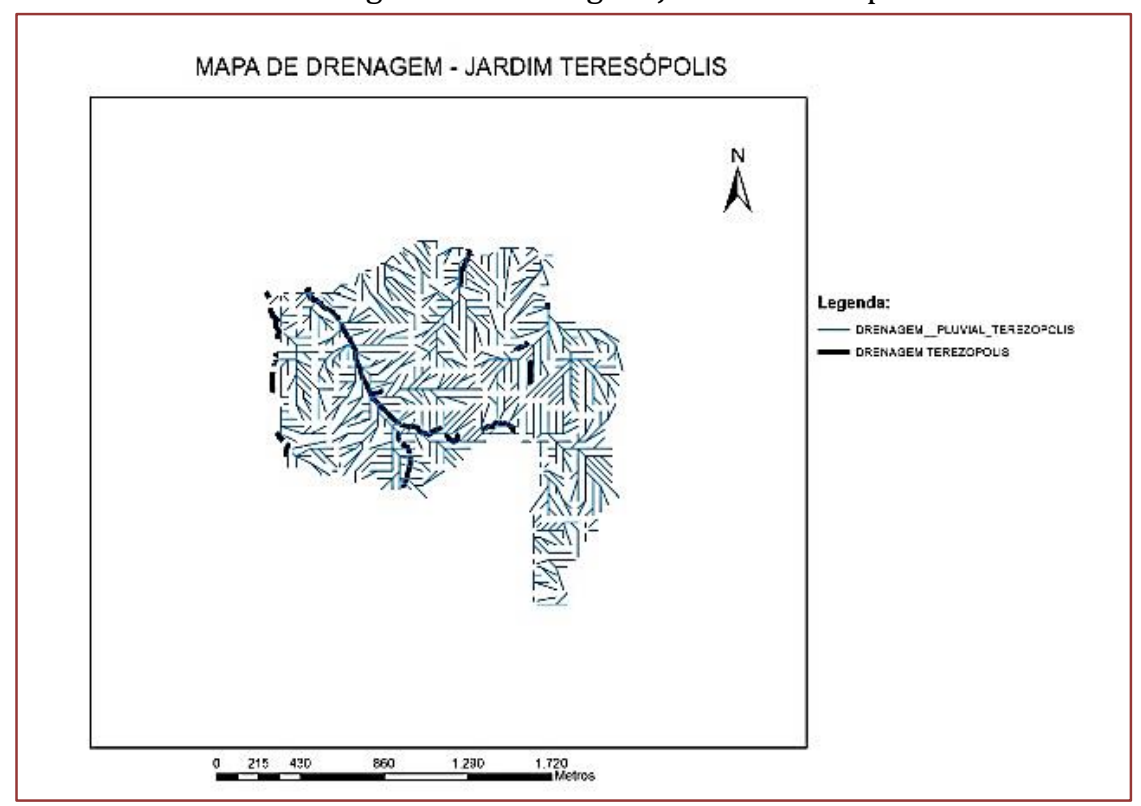

Fonte: Autoria Própria 
Ao analisar o mapa de drenagem, é identificada em azul escuro a Bacia Riacho das Areias e em azul claro o sentido do escoamento pluvial. Avaliando os pontos de maior deslizamento no bairro, é possível relacionar a erosão no solo dessa região a esse sentido de drenagem pluvial que circunda essas vertentes. 0 que aponta para uma maior saturação do solo e o seu risco de rompimento, o que desencadeia deslizamentos de terras. Fator que alerta a necessidade de trabalhar a drenagem dessa área, interceptando e o conduzindo esse fluxo pluvial com segurança.

\subsubsection{SOLO}

Figura 07: Solo Jardim Teresópolis

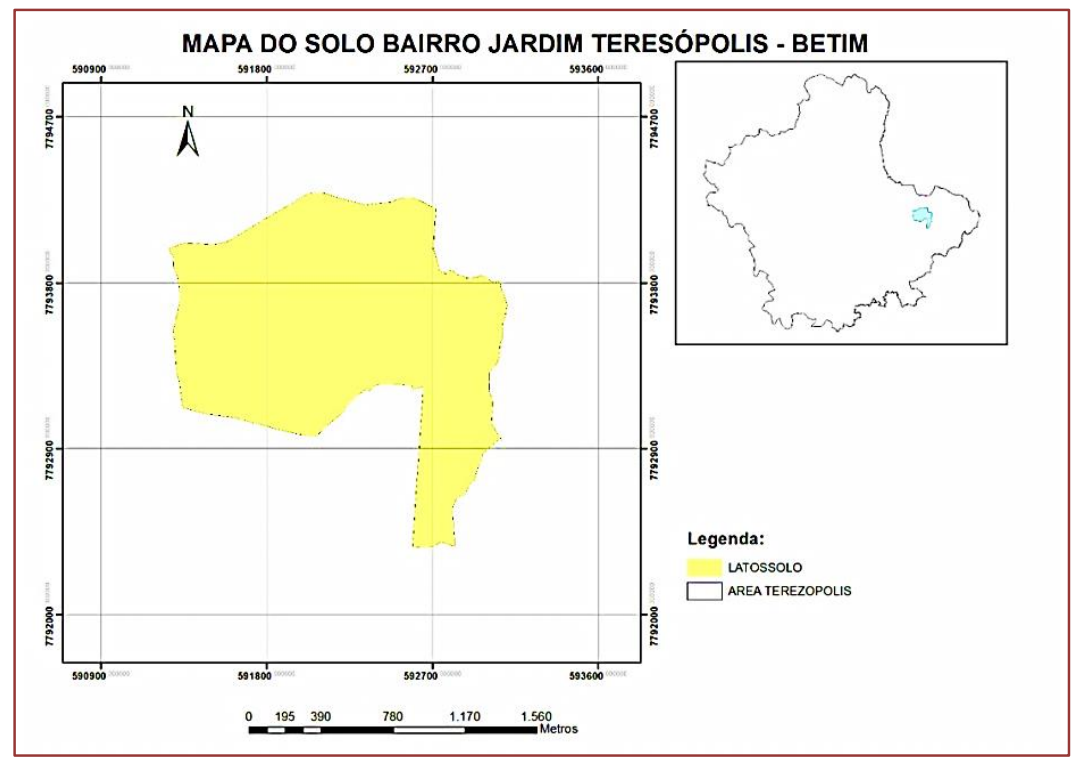

Fonte: Autoria Própria

Com este mapa foi possível perceber o tipo de solo presente no Bairro Jardim Teresópolis e a área é integramente constituída pelo tipo de solo latossólico, estes solos caracterizado por apresentar predominância de material mineral, bastante intemperizado, com horizonte diagnóstico B.

\subsection{BAIRRO DUQUE DE CAXIAS}

\subsubsection{SOLO}

Figura 08: Solo Duque de Caxias

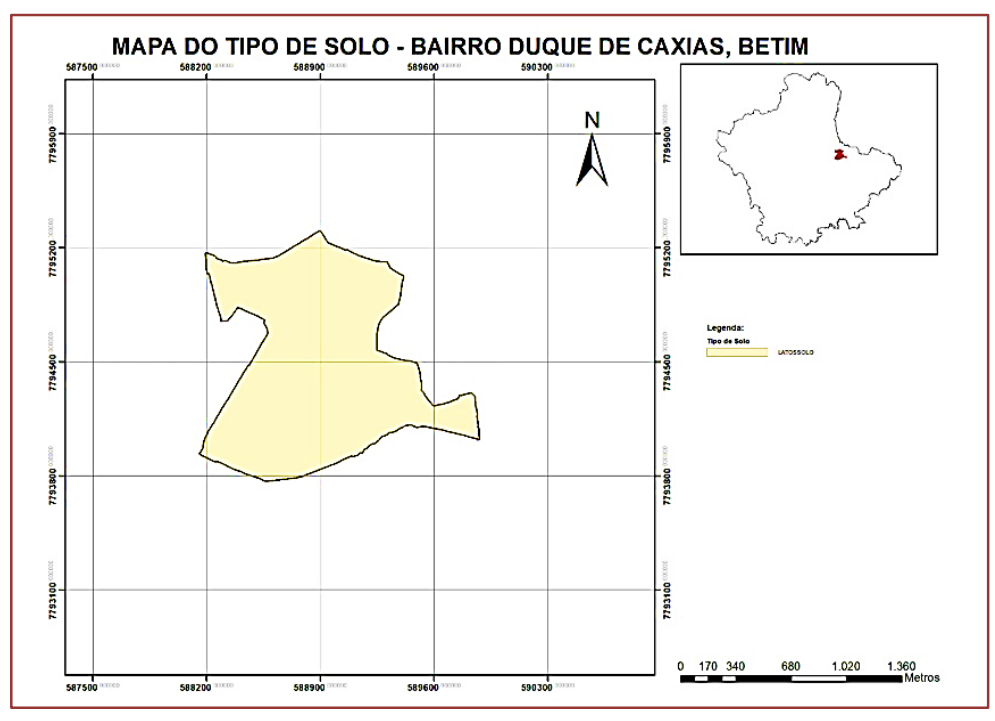

Fonte: Autoria Própria 
Através do mapa de solos, é possível identificar que no bairro Duque de Caxias o tipo solo predominantemente encontrado naquela região é o tipo Latossolo.

\subsubsection{ALTIMETRIA}

Figura 09: Altimetria Duque de Caxias

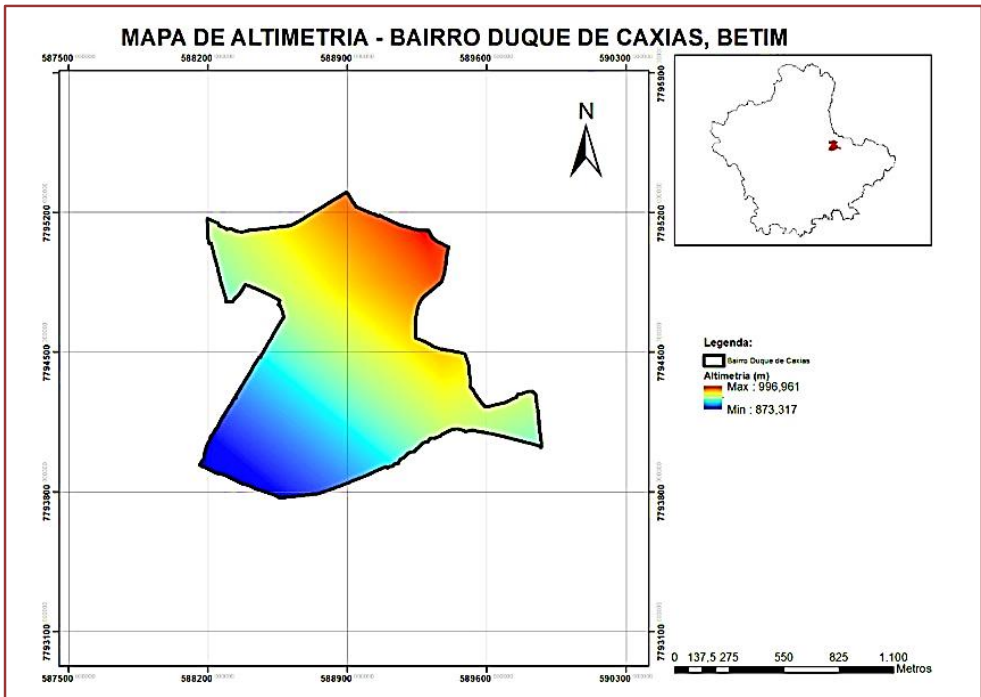

Fonte: Autoria Própria

No mapa acima é demonstrada a altimetria do bairro Duque de Caxias, onde é possível observar que o mesmo possui na parte superior do bairro, em sua extremidade direita uma altimetria em torno de 996,00 metros. Enquanto que na parte inferior em sua extremidade esquerda a altimetria gira em torno de 873,32 metros.

\subsubsection{DECLIVIDADE}

Figura 10: Declividade Duque de Caxias

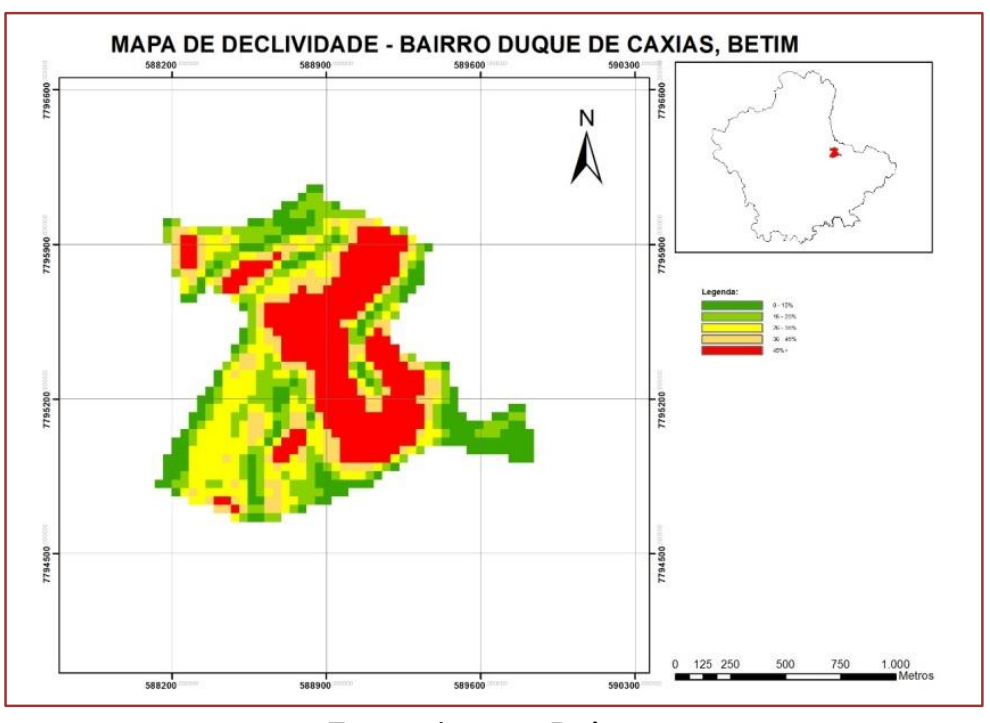

Fonte: Autoria Própria

No mapa acima é possível encontrar o mapa de declividade do bairro. É possível observar que há uma grande área no centro do bairro que possui uma declividade superior a $45 \%$, enquanto que nas extremidades do mesmo a declividade está entre $15 \%$ a $32 \%$. 


\subsubsection{DRENAGEM}

Figura 11: Drenagem Duque de Caxias

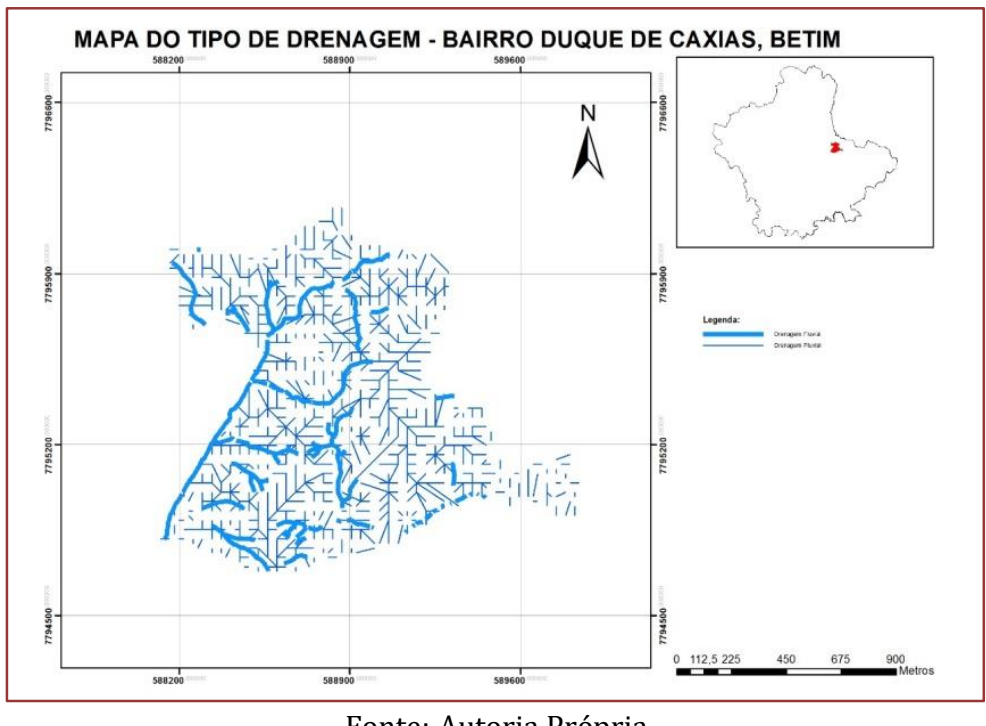

Fonte: Autoria Própria

Através do mapa acima foi possível então estabelecer um mapa com a possível drenagem que ocorre no Bairro Duque de Caxias, tanto a drenagem fluvial (representada pelas linhas em azul mais espessas) como a drenagem fluvial (linha em azul mais estreita).

\subsubsection{MANCHA URBANA}

Figura 12: Mancha Urbana Duque de Caxias

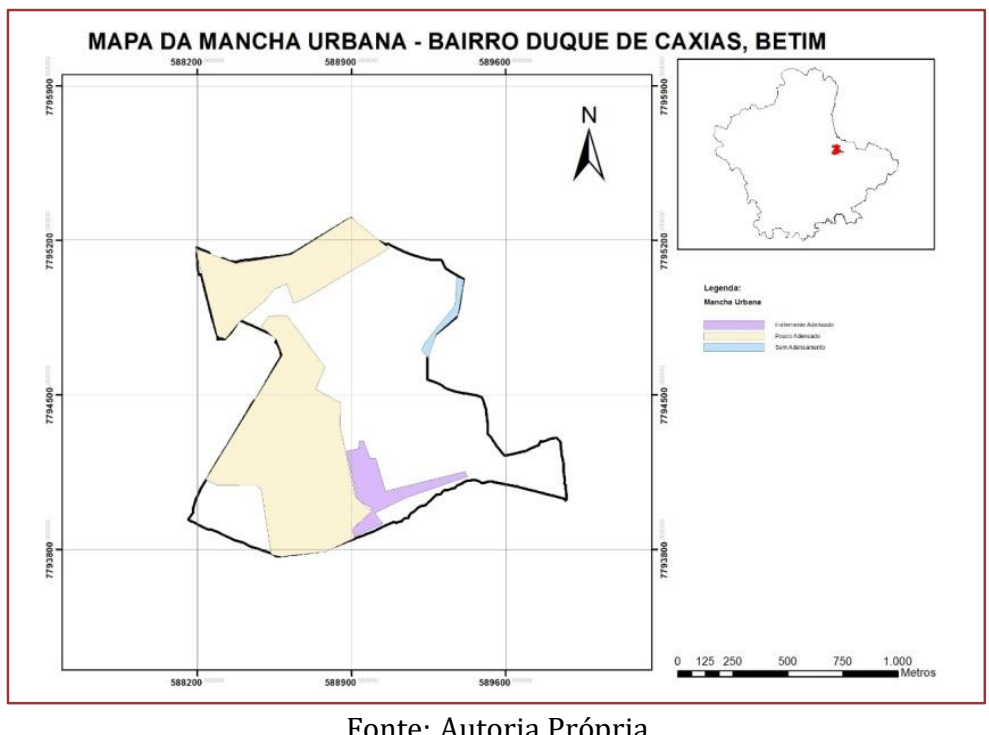

A mancha urbana encontrada no Bairro Duque de Caxias. Representada pela cor rosa se encontra uma área com pouco adensamento, a cor roxa mais ao centro do mapa apresenta uma área fortemente adensada enquanto que a cor azul que se encontra na extremidade direita da imagem representa uma área sem adensamento. 


\subsubsection{MANCHA DA VEGETAÇÃO}

Figura 13: Mancha de Vegetação Duque de Caxias

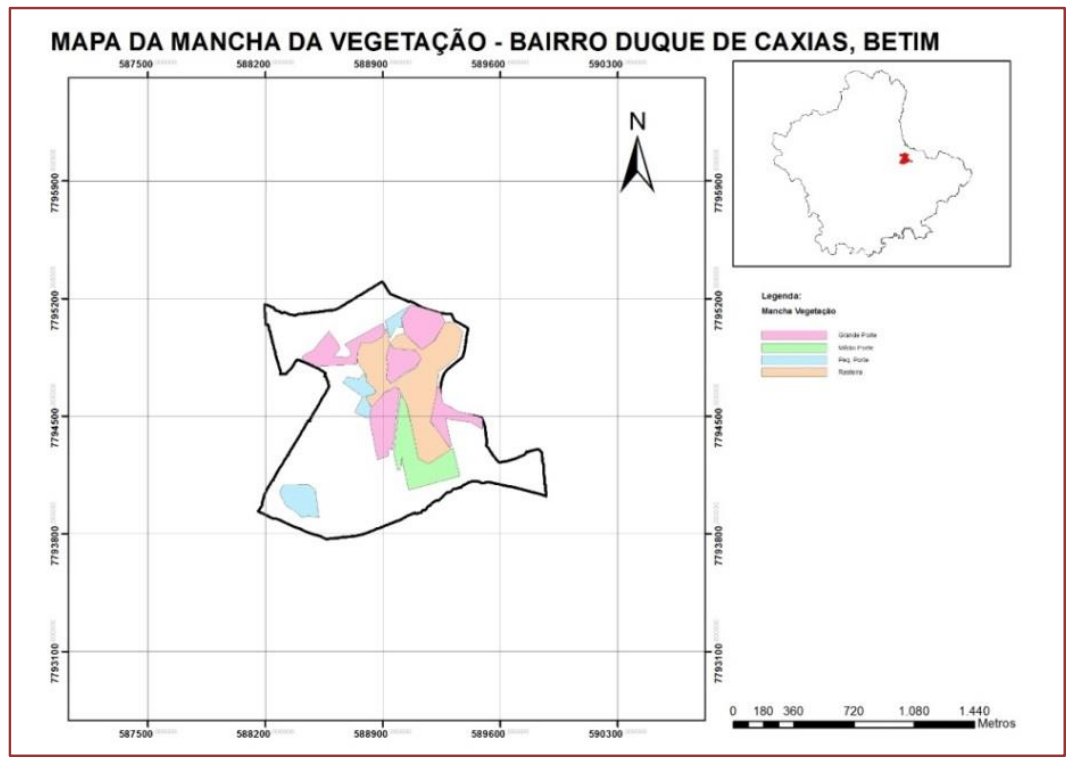

Fonte: Autoria Própria

A representação da vegetação presente no bairro. Nas áreas que se encontra um tom de rosa mais escuro é possível ser encontrada uma vegetação de grande porte. Nas áreas representadas pela cor verde a vegetação existente ali é considerada de médio porte e nas áreas em azul e rosa claro, são encontradas respectivamente, uma vegetação de pequeno porte e rasteiras.

\section{CONCLUSÕES}

O bairro Jardim Teresópolis possui uma área total de $1.9 \mathrm{~km}^{2}$ e obtiveram $0.02 \mathrm{~km}^{2}$ de áreas suscetíveis a deslizamentos de massa, isso é o equivalente a 1,05\%.

Figura 14: Susceptibilidade a erosão Jardim Teresópolis

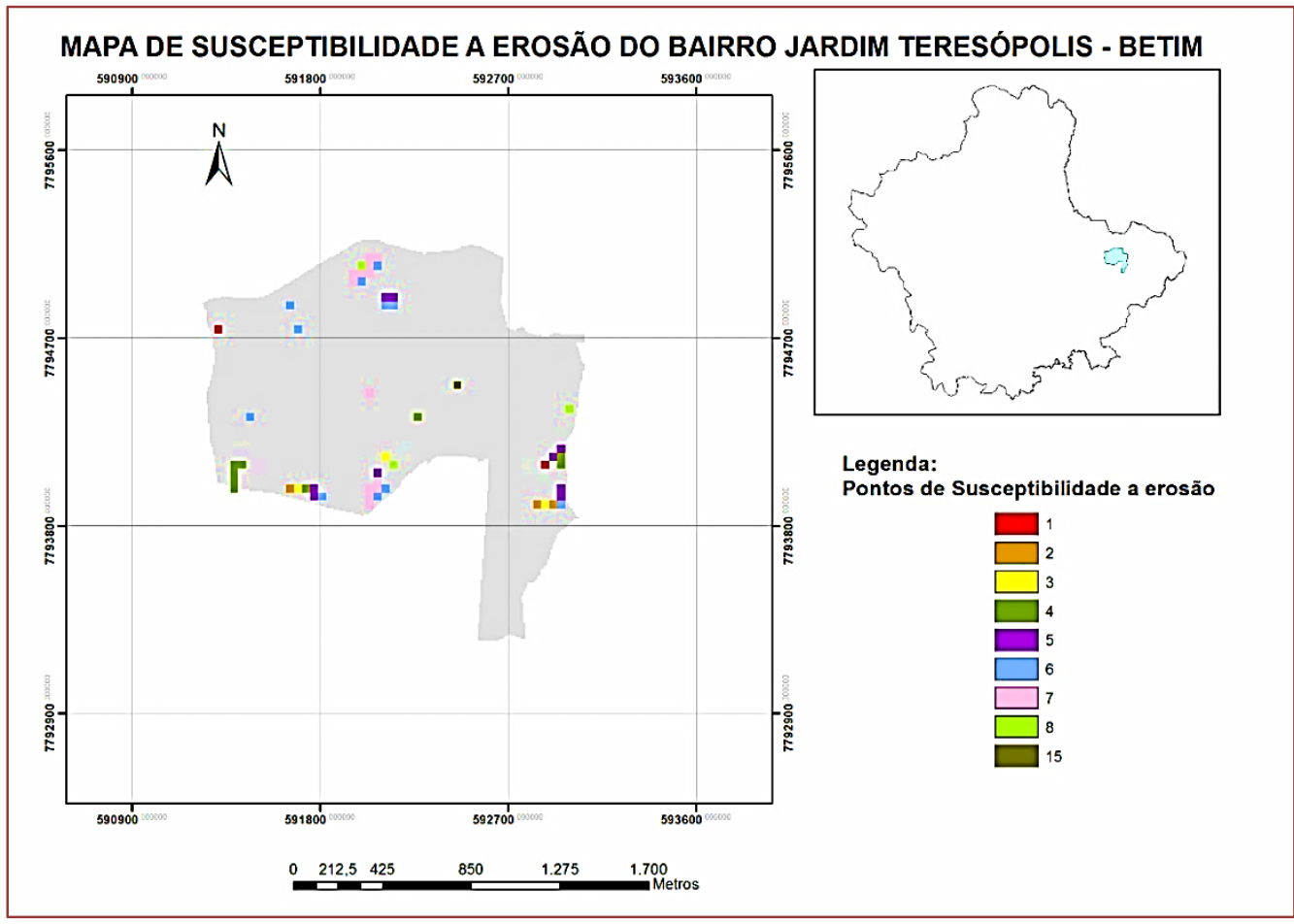

Fonte: Autoria Própria 
0 Duque de Caxias apresenta uma área total de $1.43 \mathrm{~km}^{2}$ com $0.407 \mathrm{~km}^{2}$ de áreas suscetíveis a deslizamentos de massa, isso é o equivalente a $28,46 \%$.

Figura 15: Susceptibilidade a erosão Duque de Caxias

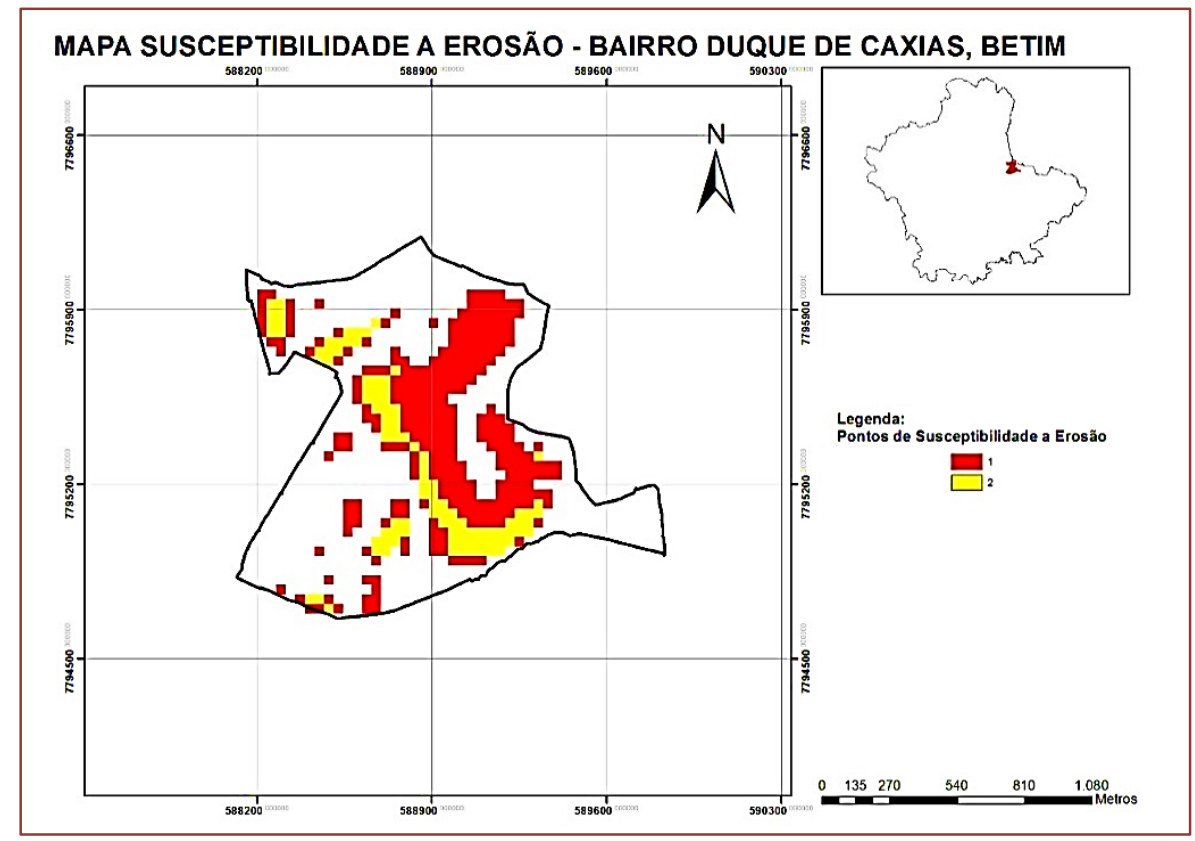

Fonte: Autoria Própria

Mesmo os dois bairros apresentando no começo do ano de 2020 um elevado potencial de erosões, percebe-se que o bairro Duque de Caxias apresenta um percentual de susceptibilidade superior ao bairro Jardim Teresópolis, os fatores evidenciados pelo cruzamento das varáveis justificam-se pela alta declividade e por possuir uma grande área sem vegetação. A relação do Jardim Teresópolis possuir um baixo potencial é justificada pelo adensamento urbano em detrimento a sua baixa declividade. A análise não leva em consideração a precariedade das construções e suas fundações, algo que foi determinante nas chuvas do inicio de 2020.

\section{REFERÊNCIA}

[1] BETIM (Município). Lei Complementar nº. 07, de 28 de dezembro de 2018. Dispõe Sobre A Revisão Do Plano Diretor Do Município De Betim (3590), Minas Gerais, p. 13-20, 27-38, 2020. Disponível em:< http://www.dpurb.betim.mg.gov.br/site/wp-content/plugins/download-monitor/download.php?id=527>. Acesso em: 20 abr. 2020.

[2] BRASIL, Agência Nacional de Águas - Diretrizes e análises recomendadas para a consistência de dados pluviométricos / Agência Nacional de Águas; Superintendência de Gestão da Rede Hidrometeorológica. -- Brasília: ANA, SGH, 2011.

[3] CASU, F. et al. Big Remotely Sensed Data: tools, applications and experiences. Remote Sens. Environ, v. 202, n. 1 , p. $1-2,2017$.

[4] DENGSHENG Lu, QIHAO WENG \& GUIYING Li (2006) Estimativa de população residencial usando uma abordagem de superfície impermeável derivada de sensoriamento remoto, International Journal of Remote Sensing, 27:16, 3553-3570, DOI: 10.1080 / 01431160600617202

[5] EMBRAPA, Sistema Brasileiro de Classificação de Solos. 2018. 5a edição.

[6] GARCEZ, Lucas Nogueira; ALVAREZ, Guillermo Acosta. Hidrologia. 2ª edição. São Paulo: Ed. Edgard Blücher, 1988.

[7] LEI COMPLEMENTAR № 07, DE 28 DE DEZEMBRO DE 2018 . Disponível em: <http://www.dpurb.betim.mg.gov.br/site/index.php/legislacao-2/plano-diretor/> Acesso em 08 de maio de 2020.

[8] NETO, Queiroz. J.P. Pedologia: Conceito, Método e Aplicações. 1982. 
[9] OLIVEIRA,S.T. Paulo et al. Zoneamento Ambiental Aplicado à Conservação do Solo e da Água. Revista Brasileira de Solos. 2011.

[10] PLANTA Geral (1846). Lei Complementar 007/18 - Plano Diretor Do Município De Betim. Escala Gráfica. Disponível em: < http://www.dpurb.betim.mg.gov.br/site/wp-content/plugins/downloadmonitor/download.php?id=531>. Acesso em: 20 abr. 2020 .

[11] SANTOS, I. dos et al. Hidrometria aplicada. Curitiba: Instituto de Tecnologia para o desenvolvimento, 2001.

[12] SCHIEBELBEIN, Luis Miguel. Gestão de Recursos Hídricos e Sustentabilidade. 2019.

[13] TUCCI, C. E. M. Hidrologia: ciência e Aplicação / organizado por Carlos E. M. Tucci - 2ª Ed.; 2. Reimp. - Porto Alegre: Ed. Universidade / UFRGS: ABRH, 2001

[14] VALERIANO,M,Márcio e ALBUQUERQUE,C.G.Paulo, Derivação de Modelos Digitais de Elevação (MDE) em coordenadas geográficas. INPE. 2008.

[15] WENG, Qihao. Remote sensing of impervious surfaces in the urban areas: Requirements, methods, and trends. Remote Sensing of Environment, v. 117, p. 34-49, 2012

[16] ALVES, José Augusto. Sobe para 167 o número de ocorrências em Betim por causa das chuvas. 0 Tempo Betim, Minas Gerais, 24 de jan. de 2020. Disponível em: https://www.otempo.com.br/o-tempo-betim/sobe-para-167o-numero-de-ocorrencias-em-betim-por-causa-das-chuvas-1.2288557. Acesso em: 18 de mai. de 2020.

[17] Jornal Hoje Em Dia. Oito ficam soterrados em desmoronamentos no Jardim Teresópolis e Duque de Caxias, em Betim. Disponível em : < https://www.hojeemdia.com.br/horizontes/cidades/oito-ficam-soterrados-emdesmoronamentos-no-jardim-teres\%C3\%B3polis-e-duque-de-caxias-em-betim-1.768853>. Acesso em: 08 de maio de 2020.

[18] Oliveira, Cinthya. Duas vítimas de desmoronamento em Betim são resgatadas com vida; seis morreram durante tempestade. Hoje em Dia, Minas Gerais, 25 de jan. de 2020. Disponível em: https://www.hojeemdia.com.br/horizontes/duas-v\%C3\%ADtimas-de-desmoronamento-em-betim-s\%C3\%A3oresgatadas-com-vida-seis-morreram-durante-tempestade-1.768923 Acesso em: 18 de mai. de 2020.

[19] Pereira, Maria Irenilda. Deslizamento de encosta soterra duas casas e mata quatro pessoas em Betim. Estado de Minas Gerais, Minas Gerais, 25 de jan. de 2020. Disponível em: https://www.em.com.br/app/noticia/gerais/2020/01/25/interna_gerais,1116950/deslizamento-de-encostasoterra-duas-casas-e-mata-quatro-pessoas-em-be.shtml Acesso em: 18 de mai. de 2020.

[20] WMO (2018). Guide to climatological practices. World Meteorological Organization - WMO Geneva, 117 p.

[21] http://www.betim.mg.gov.br/ARQUIVOS_ANEXO/relatoriobetim;0724280503;20070213.pdf - Acessado 05/05/2020 às 18:30h

[22] CNPS-Procedimentos-normativos-levantamentos-pedologicos1995.pdf - Acessado 05/05/2020 às 18:40h

[23] http://vpcbrasil.com.br/portfolio-view/levantamento-geologico/ - Acessado dia 11/05/2020 às 23:04h

[24] https://nacoesunidas.org/pos2015/ods11/ - Acessado dia 23/08/2020 às 00:54h 


\section{Capítulo 19}

\section{Construção de uma matriz de ponderação para análise integrada dos aspectos e impactos ambientais em parque eólico}

\section{Lucidalva Rodrigues de Souza Nogueira \\ Admilson Írio Ribeiro \\ Gerson Araújo de Medeiros}

Resumo : A produção de energia elétrica pode ser considerada uma das atividades mais importantes para o desenvolvimento de quase todas as atividades em nossa sociedade. Atualmente muitas empresas estão se colocando em nosso país, particularmente na região Nordeste, devido às condições ambientais para geração de energia eólica. Assim, como toda ação antrópica, a utilização dos ventos para geração de a energia elétrica apresenta impactos positivos e negativos. 0 objetivo dessa pesquisa foi realizar uma análise integrada dos aspectos e impactos ambientais na operação dos Parques Eólicos Morrinhos Guanambi\Bahia, utilizou-se do método matriz de ponderação. Como resultado foi identificado com os seguintes critérios: intensidade, amplitude, temporalidade, reversibilidade. Dentre os impactos positivos destacados pode ser citada a melhoria das condições de vida dos proprietários de terra os quais são contratados por arrendamento do uso da área; à geração de empregos na instalação e operação do empreendimento, pois sugiram oportunidades de serviços local e regional. Destaca se também como impacto positivo significativo o aumento de recursos econômicos para os municípios da região dado o aumento na arrecadação de impostos e tributos. Assim, a sociedade local entende que produção de energia eólica auxilia desenvolvimento socioeconômico. A produção de energia eólica, mesmo sendo uma fonte renovável, promove também impactos negativos. Os impactos negativos mais significativos percebidos pela comunidade foram: emissão de ruídos oriundo das torres em funcionamento; a ruptura da paisagem local devido à instalação do conjunto de aerogeradores que modificam a paisagem natural do ambiente.

Palavras-chave: Energia renovável; Método de Avaliação; Fase de operacionalização. 


\section{INTRODUÇÃO}

Nas últimas décadas o Brasil tornou-se mundialmente reconhecido na geração e na distribuição de energia renovável a partir de hidroelétricas, sendo sua matriz energética considerada relativamente limpa (SANTOS, 2017). Contudo, o país ainda carece de políticas públicas que favoreçam a ampliação e a diversificação do sistema energético.

A geração de energia elétrica, há algum tempo, tem provocado atritos entre governos e grupos privados que tem a sua exploração limitada e tem provocado aumento na emissão de gás carbônico na nossa atmosfera. (SILVEIRA, 2012).

Entre as vantagens socioeconômicas das energias renováveis destacam-se o uso de novas tecnologias; o crescimento das indústrias; a globalização de seu uso; o crescimento da região e o surgimento de novos trabalhos, (SIMAS, 2012). No tocante à produção de energia eólica, são diversas as vantagens, tais como a ausência de gases e de resíduos na atmosfera; não translocação de comunidades, preservação de fauna e flora, assim como não impede o uso da terra (DAMASCENO et al, 2018). Todavia, surgem impactos negativos socioambientais provocados pelas modificações e/ou ações do ser humano.

Entretanto, a energia eólica pode ser apontada como uma das mais viáveis fontes de energia sustentável, onde a economia, o social e o ambiental se equilibram em quase todos os aspectos quando comparado como a matriz de energia atual.

O objetivo desta pesquisa foi realizar uma análise integrada dos aspectos e impactos ambientais na fase operacional dos Parques eólicos - Guanambi\Bahia, distrito de Morrinhos.

\section{METODOLOGIA}

O Parque Eólico Complexo Alto Sertão I e II considerados um dos maiores da América Latina, estão instalados nos municípios de Guanambi, Pindaí, Igaporã e Caetité, no estado da Bahia. Em destaque para essa pesquisa se avaliou o distrito de Morrinhos no município de Guanambi, a 796 km do sudoeste da capital Salvador.

Para análise integrada dos aspectos e impactos ambientais foi realizada uma análise descritiva, mediante visitas in loco ao longo do Parque Eólico no município de Guanambi/Bahia no distrito de Morrinhos no ano de 2017/2018. Nessa análise foram utilizados registros fotográficos e avaliação visual dos impactos positivos e negativos com a colaboração de alguns moradores da comunidade local.

0 método matriz de ponderação proporciona uma simples percepção do social no total discute condições gerais, organiza informações quali - quantitativas, direciona ações para a prática e nas pesquisas e inclui a versão interdisciplinaridade.

Para elaboração do método matriz de ponderação, baseou-se nos estudos realizados pelos autores (RIBEIRO et.al 2015).

\section{RESULTADOS E DISCUSSÃO}

Para a análise integrada dos aspectos e impactos ambientais foi aplicado o método matriz de ponderação, com os seguintes critérios: intensidade, amplitude, temporalidade, reversibilidade. Facilitando, dessa forma, a avaliação dos impactos positivos e negativos com maior e menor significância das atividades. Nessa fase de operação do empreendimento, como apresentado na Tabela 1. Esse método, segundo Cremonez et al. (2014) apud Moraes e D'Aquino (2016), possui uma listagem de controle bidimensional em que são relacionados os aspectos e impactos ambientais, tal listagem surgiu a partir da tentativa de suprir as carências do método de checklist.

Na análise do método realizado foi possível identificar os impactos ambientais negativo, com maior significância ponderada: ruptura da paisagem natural, emissão de ruído. Como também, os impactos ambientais positivos de maior significância ponderada: geração de empregos, produção de energia eólica, arrendamento das terras e o aumento de recurso econômico no município na Tabela 1. 
Tabela 1. Matriz de Ponderação

\begin{tabular}{|c|c|c|c|c|c|c|c|c|c|c|}
\hline & \multirow[b]{2}{*}{ Impacto Ambiental } & \multicolumn{2}{|c|}{ Impacto direto } & \multicolumn{2}{|c|}{ Impacto indireto } & \multirow[b]{2}{*}{ Intensidade } & \multirow[b]{2}{*}{ Amplitude } & \multirow[b]{2}{*}{ Temporatidade } & \multirow[b]{2}{*}{ Reversibilidade } & \multirow{2}{*}{$\begin{array}{c}\text { Significaincia } \\
\text { ponderada }\end{array}$} \\
\hline Aspecto Ambiental & & Positivo & Negativo & Positivo & Negativo & & & & & \\
\hline \multirow{14}{*}{$\begin{array}{c}\text { Aerogeradores } \\
\text { em } \\
\text { funcionamento }\end{array}$} & Efeito estroboscópio & - & $\mathrm{x}$ & - & - & $1 * 5=5$ & $3 * 3=9$ & $1 * 1=1$ & $1 * 3=3$ & 18 \\
\hline & Ruptura da paisagem & - & $\mathrm{x}$ & - & - & $5 * 5=25$ & $5 * 3=15$ & $1 * 1=1$ & $1 * 3=3$ & 44 \\
\hline & Interferência eletromagnética & - & $\mathrm{x}$ & - & - & $1 * 5=5$ & $3 * 3=9$ & $1 * 1=1$ & $1 * 3=3$ & 18 \\
\hline & Otimização do uso da terra & $\mathrm{x}$ & - & - & - & $5 * 5=25$ & $3 * 3=9$ & $1 * 1=1$ & $1 * 3=3$ & 38 \\
\hline & $\begin{array}{l}\text { Alteração na rota migratória da } \\
\text { fauna }\end{array}$ & - & $\mathrm{x}$ & - & - & $3 * 5=15$ & $3 * 3=9$ & $1 * 1=1$ & $1 * 3=3$ & 28 \\
\hline & Emissão de ruídos: dinâmicos & - & $\mathrm{x}$ & - & - & $5 * 5=25$ & $3 * 3=9$ & $1 * 1=1$ & $1 * 3=3$ & 38 \\
\hline & $\begin{array}{l}\text { Melhoria da qualificação } \\
\text { profissional local }\end{array}$ & - & - & $\mathrm{x}$ & - & $1 * 5=5$ & $3 * 3=9$ & $1 * 1=1$ & $1 * 3=3$ & 18 \\
\hline & Produção de energia eólica & $\mathrm{x}$ & & & & $3 * 5=15$ & $5 * 3=15$ & $1 * 1=1$ & $1 * 3=3$ & 34 \\
\hline & $\begin{array}{l}\begin{array}{l}\text { Mortalidade da avifauna } \\
\text { morcegos }\end{array} \\
\end{array}$ & - & - & - & $\mathrm{x}$ & $1 * 5=5$ & $3 * 3=9$ & $1 * 1=1$ & $1 * 3=3$ & 18 \\
\hline & Piora na qualidade da saúde local & - & - & $=$ & $\mathrm{x}$ & $1 * 5=5$ & $3 * 3=9$ & $1 * 1=1$ & $1 * 3=3$ & 18 \\
\hline & Geração de emprego & - & - & $\mathrm{x}$ & - & $5 * 5=25$ & $5 * 3=15$ & $1 * 1=1$ & $1 * 3=3$ & 44 \\
\hline & Aumento de desemprego & - & - & - & $\mathrm{x}$ & $1 * 5=5$ & $5 * 3=15$ & $1 * 1=1$ & $1 * 3=3$ & 24 \\
\hline & $\begin{array}{l}\text { Aumento de recurso econômico no } \\
\text { município }\end{array}$ & - & - & $\mathrm{x}$ & & $3 * 5=15$ & $3 * 3=9$ & $1 * 1=1$ & $1 * 3=3$ & 28 \\
\hline & $\begin{array}{l}\text { Diminuição de recurso econômico } \\
\text { no município }\end{array}$ & - & - & - & $\mathrm{x}$ & $1 * 5=5$ & $3 * 3=9$ & $1 * 1=1$ & $1 * 3=3$ & 18 \\
\hline Funcionários , & Manutenção dos aerogeradores & $\mathrm{x}$ & - & - & - & $1 * 5=5$ & $3 * 3=9$ & $1 * 1=1$ & $1 \neq 3=3$ & 18 \\
\hline 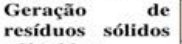 & $\begin{array}{l}\text { Infraestrutura } \\
\text { local/moradia/transportes }\end{array}$ & $\mathrm{x}$ & & - & - & $1 * 5=5$ & $3 * 3-9$ & $1 * 1=1$ & $1 * 3=3$ & 18 \\
\hline e líquidos & Melhoria da qualidade de vida & - & - & $\mathrm{x}$ & - & $2 * 5=10$ & $3 * 3=9$ & $3 * 1-3$ & $1 * 3=3$ & 25 \\
\hline & Riscos de acidente no trabalho & - & - & - & $\mathrm{x}$ & $1 * 5=5$ & $3 * 3=9$ & $1 * 1=1$ & $3 * 3=9$ & 24 \\
\hline & Arrendamento das terras & $\mathrm{x}$ & - & - & - & $5 * 5=25$ & $3 * 3=9$ & $1 * 1=1$ & $1 * 3=3$ & 38 \\
\hline & Desmatamento & - & $\mathrm{x}$ & - & - & $1 * 5=5$ & $3 * 3=9$ & $3 * 1=3$ & $1 * 3=3$ & 20 \\
\hline $\begin{array}{l}\text { Local de } \\
\text { funcionamento }\end{array}$ & $\begin{array}{l}\text { Aumento da mobilidade de } \\
\text { pessoas e veículos }\end{array}$ & - & $\mathrm{x}$ & - & - & $2 * 5=10$ & $3 * 3=9$ & $1 * 1=1$ & $1 * 3=3$ & 23 \\
\hline & Diminuição da flora e fauna & - & - & - & $\mathrm{x}$ & $1 * 5=5$ & $3 * 3=9$ & $1 * 1=1$ & $1 * 3=3$ & 20 \\
\hline & Restrição do uso da terra & - & - & - & $\mathrm{x}$ & $1 * 5=5$ & $3 * 3=9$ & $1 * 1=1$ & $1 * 3=3$ & 18 \\
\hline & $\begin{array}{l}\text { Aumento de animais e plantas } \\
\text { exóticas }\end{array}$ & - & - & - & $\mathrm{x}$ & $1 * 5=5$ & $3 * 3=9$ & $1 * 1=1$ & $1 * 3=3$ & 18 \\
\hline & Afugentamento da fauna & - & - & - & $\mathrm{x}$ & $1 * 5=5$ & $3 * 3=9$ & $1 * 1=1$ & $1 * 3=3$ & 18 \\
\hline
\end{tabular}

Tabela 2. Ranqueamento da significância ponderada

\begin{tabular}{|c|c|c|c|c|c|c|c|c|c|}
\hline Impacto Ambiental & \multicolumn{2}{|c|}{ Impacto direto } & \multicolumn{2}{|c|}{ Impacto indireto } & Intensidade & Amplitude & Temporalidade & Reversibilidade & Significância ponderada \\
\hline Efeito estroboscópio & - & $\mathrm{x}$ & - & - & $1 * 5=5$ & $3 * 3=9$ & $1 * 1=1$ & $1^{*} 3=3$ & 18 \\
\hline Melhoria da qualificą̧ăo profissional local & - & - & $\mathrm{x}$ & - & $1 * 5=5$ & $3 * 3=9$ & $1 * 1=1$ & $1^{*} 3=3$ & 18 \\
\hline Mortalidade da avifauna e morcegos & - & - & - & $\mathrm{x}$ & $1 * 5=5$ & $3 * 3=9$ & $1 * 1=1$ & $1 * 3=3$ & 18 \\
\hline Piora na qualidade da saúde local & - & - & - & $\mathrm{x}$ & $1 * 5=5$ & $3 * 3=9$ & $1 * 1=1$ & $1 * 3=3$ & 18 \\
\hline Infraestrutura local/moradia/transportes & $\mathrm{x}$ & & - & - & $1 * 5=5$ & $3 * 3-9$ & $1 * 1=1$ & $1 * 3=3$ & 18 \\
\hline Restrição do uso da terra & - & - & - & $\mathrm{x}$ & $1 * 5=5$ & $3 * 3=9$ & $1^{*} 1=1$ & $1 * 3=3$ & 18 \\
\hline Aumento de animais e plantas exóticas & - & - & - & $\mathrm{x}$ & $1 * 5=5$ & $3 * 3=9$ & $1 * 1=1$ & $1 * 3=3$ & 18 \\
\hline Afugentamento da fauna & - & - & - & $\mathrm{x}$ & $1 * 5=5$ & $3 * 3=9$ & $1 * 1=1$ & $1 * 3=3$ & 18 \\
\hline Desmatamento & - & $\mathrm{x}$ & - & - & $1 * 5=5$ & $3 * 3=9$ & $3 * 1=3$ & $1 * 3=3$ & 20 \\
\hline Diminuição da flora e fauna & - & - & $\cdot$ & $\mathrm{x}$ & $1 * 5=5$ & $3 * 3=9$ & $1 * 1=1$ & $1 * 3=3$ & 20 \\
\hline Melhoria da qualidade de vida & - & - & $\mathrm{x}$ & - & $2 * 5=10$ & $3 * 3=9$ & $3^{*} 1-3$ & $1 * 3=3$ & 25 \\
\hline Aumento de recurso econômico no município & - & - & $\mathrm{x}$ & & $3 * 5=15$ & $3 * 3=9$ & $1 * 1=1$ & $1 * 3=3$ & 28 \\
\hline Produçăo de energia eólica & $\mathrm{x}$ & & & & $3 * 5=15$ & $5 * 3=15$ & $1 * 1=1$ & $1 * 3=3$ & 34 \\
\hline Otimização do uso da terra & $\mathrm{X}$ & - & $\cdot$ & $\cdot$ & $5 * 5=25$ & $3^{*} 3=9$ & $1 * 1=1$ & $1 * 3=3$ & 38 \\
\hline $\begin{array}{l}\text { Emissão de ruídos: dinâmicos (geradores) e aerodinâmico } \\
\text { (pás) }\end{array}$ & - & $\mathrm{x}$ & - & - & $5 * 5=25$ & $3 * 3=9$ & $1 * 1=1$ & $1 * 3=3$ & 38 \\
\hline Arrendamento das terras & $\mathrm{x}$ & - & $\cdot$ & - & $5^{*} 5=25$ & $3 * 3=9$ & $1 * 1=1$ & $1 * 3=3$ & 38 \\
\hline Ruptura da paisagem & - & $\mathrm{x}$ & - & - & $5 * 5=25$ & $5 * 3=15$ & $1^{*} 1=1$ & $1 * 3=3$ & 44 \\
\hline Geração de emprego & - & - & $\mathrm{x}$ & - & $5 * 5=25$ & $5 * 3=15$ & $1^{*} 1=1$ & $1 * 3=3$ & 44 \\
\hline
\end{tabular}

Legenda:

Impacto Pouco Significativo

Impacto Significativo

Impacto Muito Significativo

\section{CONCLUSÕES}

A utilização da matriz de ponderação chegou aos resultados dos impactos positivos e negativos com maior significância ponderada.

A metodologia usada apresenta potencial para auxiliar os órgãos de controle ambiental em causas de licenciamento ambiental. 
Pesquisas como essa são fundamentais para subsidiar tomadas de decisão, assim como, oferecer um panorama dos impactos positivos e negativos em relação ao uso de energia eólica.

\section{REFERÊNCIAS}

[1] DAMASCENO, V.S; ABREU, Y. V. Avaliação da energia eólica no Brasil utilizando a análise SWOT e PESTEL. INTERAÇÕES, Campo Grande, MS, v. 19, n. 3, p. 503-514, jul./set. 2018.

[2] OLIVEIRA, F. C; MOURA, H. J. T. Uso das metodologias de avaliação de impacto ambiental em estudos realizados no Ceará. Revista Pretexto, v. 10, n. 4, 2009.

[3] ROCHA, E. C.; CANTO, J. L.; PEREIRA, P. C. Avaliação de impactos ambientais nos países do MERCOSUL. Ambiente \& Sociedade, v.8, n.2. 2005.

[4] MORAES, C., D; AQUINO, C. A. Avaliação de impacto ambiental: uma revisão da literatura sobre as principais metodologias. 2016. Disponível em:< http://labhidrogeo.paginas.ufsc.br/files/2016/08/AIA-UMA-REVIS\%C3\%830DA-LITERATURA-SOBRE-AS-PRINCIPAIS-METODOLOGIAS.pdf >>. Acesso em: 31 jul. 2018.

[5] RIBEIRO, A. I.; FENGLER, F. H.; LONGO, R. M.; MEDEIROS, G. A.; MELLO, G. F. \& FILHO, A. P. Choice of revegetation techniques for degraded areas using environmental damage assessment in the Amazon Forest, Brazil. WIT Transactions on Ecology and The Environment. v.192, p.407-417, 2015.

[6] SANTOS, L. T. Avanços da energia eólica no Brasil: uma análise das políticas públicas e seus resultados. 2017. 98 f. Dissertação (Mestrado) - Curso de Engenharia e Desenvolvimento Sustentável, Gestão Sustentável e Energia., Universidade Federal do Espírito Santo, Vitória, 2017.

[7] SIMAS, M. S. Energia Eólica e Desenvolvimento Sustentável no Brasil: Estimativa da Geração de Empregos por meio de uma Matriz Insumo-Produto Ampliada. 2012. 220 f. Dissertação (Mestrado) - Curso de Administração, Universidade de São Paulo, São Paulo, 2012. Disponível em: <http://www.teses.usp.br/teses/disponiveis/86/86131/tde-10092012-095724/en.php>. Acesso em: 22 ago. 2018.

[8] SILVEIRA, G. P. O papel da energia eólica no desenvolvimento econômico brasileiro.2012. 58 f. Monografia Curso de Bacharelado em Ciências Econômicas. Ciências Econômicas, Universidade Federal de Santa Catarina, Florianópolis, 2012. 


\section{Capítulo 20}

\section{Avaliação técnica visual das condições fitossanitárias das árvores do centro a do município de Governador Valadares-MG}

\section{Rafael Teixeira Coelho \\ Maria Luiza de Melo Vieira \\ Marlon Campos Coelho}

Resumo: A vegetação arbórea é de suma importância para as áreas urbanas por produzir benefícios como diminuição da poluição sonora e atmosférica, conforto térmico e lumínico, controle do ciclo hidrológico, entre outros. Neste sentido, a presente pesquisa teve como objetivo, investigar as ocorrências e analisar as condições fitossanitárias de espécies arbóreas da área recorte deste trabalho, no município de Governador Valadares/MG, o Centro A. As avaliações foram feitas a partir da observação de cada exemplar no percurso de todas as ruas da região estudada e também com auxilio de imagens de drone. Por esse trabalho foi constatado que apenas 10,9\% das árvores apresentam algum tipo de patologia e requerem a adoção de diversos tipos de manutenção e ainda reposição das espécies. Já o remanescente $(89,1 \%)$ se apresenta em bom estado de conservação e bem adaptado às condições do município, exigindo o acompanhamento e podas de manutenção.

Palavras-chave: Arborização urbana; Espécies arbóreas; Patologia. 


\section{INTRODUÇ̃̃O}

A arborização de áreas é de suma importância, seja por produzir benefícios para a fauna, bem como para o bem estar do ser humano a partir da diminuição da poluição sonora e atmosférica, conforto térmico, controle do ciclo hidrológico, entre outros (Ferraz, 2012).

Neste sentido, em História (2016) há um breve relato da arborização urbana de Governador Valadares, no qual elucida que antigos governantes nas décadas de 50 e 60, resolveram trocar as árvores denominadas "Ficus", porque atraíam insetos "Lacerdinha" (Thysanoptera) que queimavam as pessoas que circulavam nas ruas da cidade. Testaram, então, outras espécies, mas sem sucesso. Tão logo, após visitas destes políticos ao estado do Paraná foi que conheceram o Oiti (Licania Tomentosa) e o introduziram na cidade.

Ela se adaptou tão bem ao ambiente local que uma lei foi criada determinando o plantio de dois indivíduos a frente de cada lote. Posto isto, o município apresenta uma referência arbórea do Oiti com predominância nos bairros mais antigos.

O Oiti, como destaca Lorenzi (2009), possui diversas características favoráveis, das quais destacamos:

- Ser perenifólia;

- Possuir resistência moderada a ação de patógenos;

- Possuir boa capacidade de regeneração após poda;

- Ter madeira com boa densidade, possuindo resistência a ação mecânica (vento).

Entretanto, esta espécie possui características naturais que podem causar conflitos com a infraestrutura ao seu redor, seja pelo crescimento de raízes danificado os equipamentos urbanos, como fiações elétricas, encanamentos, calhas, calçamentos, muros, postes de iluminação, etc. (Souza, Queiroz e Brito, 2010); seja pelo diâmetro do tronco ocupando maior parte do passeio, limitando a trafegabilidade de pessoas ou até mesmo pelo crescimento da copa, podendo obstruir a iluminação, gerar conflito com cercas elétricas dos imóveis e mais recentemente, limitar o aproveitamento de sistema de geração de energia solar através de painéis sobre o telhado.

Ocorre que, com o decorrer dos anos, o plantio e a manutenção de árvores se tornou um desafio devido suas condições naturais, intempéries e diversas adaptações que incidem sobre os desdobramentos das formas de vida humana (formas de construções, passeios públicos, rede elétrica, dentre outros), que também compromete o desfrute dos benefícios que a arborização oferece.

Diante o exposto, e também considerando a ocorrência inesperada de fortes ventos e chuva de granizo em fevereiro de 2020 que provocou quedas de árvores em vários pontos da cidade, alagamentos e ainda prejuízos a patrimônios (público e privado), fez-se ainda mais necessário um estudo pormenorizado que possibilite analisar as condições dos indivíduos arbóreos.

Por tudo isso, este trabalho teve como objetivo principal, investigar as ocorrências e analisar as condições de espécies arbóreas da área citada, no município de Governador Valadares, o Centro A.

\section{METODOLOGIA}

Para esta pesquisa, foi selecionado o Centro A do município em referência, por apresentar um mix de região comercial e residencial; por abrigar os maiores centros de serviços essenciais da cidade, como escolas e hospitais públicos e particulares, além de ter sido a região mais afetada com fortes chuvas e ventos ocorridos no mês de fevereiro de 2020.

Nesta pesquisa, realizada durante os meses de março, abril e maio do ano corrente, foram realizadas três etapas de trabalho, a saber: desenvolvimento do Plano de Ação, com base na metodologia 5W2H; observação das copas das árvores com utilização de imagens de drone e; contagem e análise qualitativa de cada indivíduo arbóreo para que pudessem ser identificados os indivíduos com alguma patologia que ofereça riscos à integridade física dos cidadãos e às estruturas urbanas (patrimônios público e privado).

Foram percorridos $11.935 \mathrm{~m}$ à pé ao longo de 23 (vinte e três) ruas e 4 (quatro) praças, totalizando uma área de aproximadamente $710.000 \mathrm{~m}^{2}$, portanto planilhas, mapas, câmeras fotográficas com indicação de coordenadas geográficas. 


\section{RESULTADOS E DISCUSSÃO}

As árvores encontradas na região do Centro A são predominantemente da espécie Oiti (Licania Tomentosa), com porte médio [acima de 9 (nove) metros de altura], copa frondosa e alguns indivíduos possuem troncos ultrapassando a faixa de $50 \mathrm{~cm}$ de diâmetro.

Por esta pesquisa, foi encontrado nos resultados da coleta, sistematização e avaliação, todos os dados e informações alusivas pertinentes à caracterização dos riscos e agentes causadores do risco de queda das árvores da área recorte estudada, baseada em 5 (cinco) principais tipos de patologia. São elas:

- Poda em "v" com desequilíbrio.

- Poda mal feita com desequilíbrio.

- Poda de raiz de maneira incorreta.
- Lesão Fitossanitária.

- Raiz danificando infraestrutura.

O trajeto realizado nas ruas do Centro A possibilitou coletar dados da arborização, totalizando 1.791 (um mil, setecentos e noventa e um) indivíduos analisados. Nesta amostra, tem-se que 1.595 (um mil, quinhentos e noventa e cinco) árvores estão sadias e as 196 demais possuem algum tipo de patologia, representando $11 \%$ da amostra.

Diante ao cenário apresentado este quantitativo necessita de medidas de intervenção em nível imediato ou ainda não são possíveis de apontar o grau de periculosidade apenas com avaliação técnica visual, requerendo a utilização de equipamentos específicos. Para tanto, apontou-se 43 (quarenta e três) indivíduos arbóreos indicados para tal avaliação.

Dessa forma, para realizar a manutenção da arborização do Centro A, a equipe técnica da responsável por este estudo sugeriu a substituição/reposição daquelas árvores identificadas com alguma patologia, a partir da adoção dos seguintes critérios técnicos:

- Preferencialmente espécies nativas.

- Portes pequeno e médio.

- Estética.
- Floração.

- Lei Municipal no 6.615/2015.

Diante ao exposto, são indicadas as seguintes espécies para substituição/reposição:

- Acerola (Malpighia emarginata)

- Aroeira Salsa (Schinus molje L.)

- Canafístula (Senna multijuga)

- Ipê Branco (Tabebula róseo Alba)

- Ipê Mirim (Tecoma stans)
- Jacarandá de minas (Jacaranda cuspidifolia)

- Pau Brasil (Paubrasilia enchinata).

- Pitanga (Eugenia uniflora L.)

- Quaresmeira (Tibouchina granulosa)

\section{CONCLUSÕES}

Com este trabalho foi possível observar que a arborização urbana do Centro A de Governador Valadares/MG mostrou-se bem distribuída e adequadas para a arborização do município, haja vista que $89,1 \%$ das árvores avaliadas estão em bom estado de conservação e bem adaptadas às condições do município, sendo necessário o acompanhamento e podas de manutenção.

Contudo, em vista do tempo transcorrido, da natureza das árvores, bem como as intempéries que as mesmas sofrem ao longo destes anos, com o crescimento populacional e suas demandas que implicaram no ordenamento do espaço urbano, torna-se essencial a adoção de diversos tipos de manutenção e ainda reposição das espécies com algum tipo de patologia. 


\section{REFERÊNCIAS}

[1] FERRAZ, M.V. Inventário das árvores urbanas da cidade de Registro-SP. Revista da Sociedade Brasileira de Arborização Urbana, Piracicaba, v. 7, n. 2, p. 80-88, 2012.

[2] GOVERNADOR VALADARES, Lei nำ6.615, de 15 de janeiro de 2015. Determina a obrigatoriedade de plantio de árvores e plantas nacionais nos parques, praças, bosques e jardins públicos no município de Governador Valadares e dá outras providências. Disponível em <https://www.valadares.mg.gov.br/detalhe-da-legislacao/info/lei-ordinaria6615-2015/330>. Acesso em 10 jun. 2020.

[3] HISTÓRIA de Governador Valadares. Produção de Vanilza Bersan. Governador Valadares, 2016. Disponível em: <https://www.youtube.com/watch?v=8NvKN9wXI-M>.

[4] LORENZI, H. Árvores brasileiras: manual de identificação e cultivo de plantas arbóreas nativas do Brasil. 1. Ed. Nova Odessa: Editora Plantarum, 2009. v. 1.

[5] SOUSA, A; QUEIROZ, F.; BRITO, J. S.. Conflitos da Arborização Urbana: estudo de caso na Avenida Antonino Freire, Teresina-PI. Disponível em <http://congressos.ifal.edu.br/index.php/ connepi/CONNEPI2010/paper/viewFile/1284/466>. Acesso em 10 jun. 2020. 


\title{
Capítulo 21
}

Produção de flores e frutos de Bertholletia excelsa em ambientes florestais e desmatados do Noroeste do Pará, Brasil

\author{
Amauri José Pereira \\ Susan Aragón Carrasco \\ Troy Patrick Beldini \\ Ricardo Scoles
}

Resumo: A castanheira (Bertholletia excelsa Bonpl) é uma espécie muito estudada principalmente no seu habitat natural, a floresta ombrófila densa, mas carece-se de informações mais precisas sobre a biologia destas árvores nas áreas desmatadas que auxiliem sua conservação e manejo. 0 objetivo desta pesquisa foi comparar a floração e a frutificação das castanheiras em duas áreas com diferente cobertura vegetal (florestada e desmatada) e relacionar com possíveis fatores ambientais explicativos. Foram monitoradas 120 castanheiras com DAP > 40 cm em dois sítios: Boa Vista (Óbidos/PA) e Nova Betel (Oriximiná/PA), no Noroeste do Pará. De cada árvore, coletaram-se as coordenadas geográficas, dados dendrométricos e espaciais, avaliou-se o estado vital e reprodutivo, marcas de perturbação e rebrotamento. A contagem de flores mostrou uma floração quatro vezes maior nas áreas florestais. A produção média de frutos foi baixíssima nas áreas desmatadas, mais de vinte vezes inferior a estimativa feita nas áreas florestais. Os solos das áreas desmatadas registraram condições mais altas de compactação e fertilidade que os das áreas florestais. Entre as variáveis não edafológicas, percentual de sinais de fogo das árvores foi a única que apresentou diferenças significativas entre as duas áreas (maior nas áreas desmatadas). Concluiu-se que a compactação do solo e fogo poderia explicar parcialmente a baixa produção de frutos das castanheiras em áreas desmatadas sem descartar outros fatores ambientais não avaliados nesta pesquisa. Dada a importância ecológica das castanheiras e o mandato de lei para sua conservação, sugerem-se medidas urgentes de manejo e conservação do solo nas áreas de pastagem para garantir a conservação das castanheiras nessa região assim como de reflorestamento para recompor a reserva legal nessas áreas desmatadas com ocorrência de castanheiras.

Palavras-chave: castanheira, compactação do solo, fogo. 


\section{INTRODUÇ̃̃O}

Nas últimas quatro décadas, a Amazônia transformou-se numa nova fronteira agropecuária com a expansão de diferentes usos da terra que promoveu uma intensa perda da cobertura vegetal em extensas áreas do sul e leste da Amazônia. Desde 1970, 18\% da área florestal original já foi desmatada na Amazônia Legal (INPE, 2016). Na maioria dos casos, estas áreas florestais foram substituídas por campos de pastagens e/ou agricultura intensiva (Fearnside, 2010; Davidson et al., 2012).

Esse processo intensificou-se nas margens de estradas e ramais, facilitando o acesso a lugares preservados (Ferreira et al., 2001). De fato, a correlação entre taxa de desmatamento e estradas na Amazônia é muito forte, aumentando exponencialmente quando diminui a distância das florestas com as estradas (Ferreira et al., 2001; Nepstad et al., 2001).

Apesar de protegida por lei (BRASIL, 1994; 2006), a árvore de castanheira sofre com o corte ilegal para fins madeireiros e com as queimadas repetidas nas áreas onde a floresta foi substituída por pastagens, como pode ser visto no Noroeste do Pará (Scoles et al., 2016) e na região Sudeste do Pará, no município de Marabá (Homma et al., 2000). 0 desmatamento desenfreado produz a diminuição preocupante das populações de castanheiras principalmente no Pará, um estado que, em termos históricos, teve sempre altas taxas de desmatamento (INPE, 2016).

0 desmatamento gera numerosos efeitos negativos em termos ambientais como: erosão e compactação do solo, exaustão dos nutrientes, aumento da temperatura ambiental, diminuição da umidade ambiental e mudança nos balanços de energia e água do sistema (Luizão et al., 2007; Phillips et al., 2009; Araújo et al., 2011; Davidson et al., 2012; Nobre, 2014). A situação biológica das árvores remanescentes em áreas desmatadas é claramente desfavorável, especialmente para árvores de grande porte como a castanheira, com altas demandas de água (Nobre, 2014).

Numa área desmatada desprotegida de vegetação, o ar aquece mais rápido, o solo fica mais exposto, seco, compacto e com alto risco de erosão (Nepstad et al., 2001; Phillips et al., 2009; Phillips et al., 2010). Além disso, a ciclagem de nutrientes do ecossistema fica comprometida pela diminuição da camada de liteira, aumento da lixiviação e diminuição da atividade dos decompositores pela redução da umidade do solo (Luizão et al., 2007; Fearnside, 2010; Davidson et al., 2012).

A região Amazônica apresenta grande potencial para a exploração de produtos extrativos não madeireiros (frutos, sementes, resinas, óleos, etc.). As sementes comestíveis da castanheira (as castanhas-do-pará) são o segundo produto florestal não madeireiro mais importante para a economia da região amazônica, perdendo em importância monetária apenas para o açaí (Euterpe spp) (IBGE, 2016). Na região do Oeste do Pará, a Castanha-do-pará (Bertholletia excelsa Bonpl) é considerada o produto florestal não madeireiro mais importante em termos econômicos (IDESP, 2011).

A castanheira é a única espécie do gênero Bertholletia da família de Lecythidaceae, grupo taxonômico dominado por árvores tropicais neotropicais (Mori e Prance, 1990). B. excelsa é uma árvore de grande porte que ocorre em florestas de terra firme e se distribui de forma desigual por toda a região Amazônica em áreas florestais de clima tropical úmido (Müller et al., 1980; Mori e Prance, 1990).

A fertilização da castanheira ocorre predominantemente entre indivíduos diferentes (reprodução alógama), havendo mecanismos de autoincompatibilidade genética (Sujii et al., 2015). A flor é estruturada com uma câmara constituída de estaminódios congruentes que criam uma estrutura robusta (lígula), que esconde os estames e o estigma, essa característica restringe e seleciona os polinizadores em relação ao seu vigor físico e seu tamanho. Seus polinizadores são abelhas solitárias que pertencem à família Apidae, do gênero Bombus (Bombini), Centris e Epicharis (Centridini), Eulaema (Euglosini) e Xylocopa (Xylocopini) (Mori et al., 1978; Muller et al., 1980; Nelson et al., 1985; Maués, 2002; Santos e Absy, 2010; Cavalcante et al, 2012).

0 fruto da castanheira é constituído por um ouriço lenhoso do tipo arredondado que pesa entre $200 \mathrm{~g}$ a $1,5 \mathrm{~kg}$; contem de 12 a 25 sementes, que pesam de 4 a $10 \mathrm{~g}$ cada amêndoa (Mori e Prance, 1990). Os ouriços não se abrem espontaneamente necessitando de agentes externos para que essa ação ocorra (Mori e Prance, 1990). 0 amadurecimento dos frutos dura 14 meses. 0 fruto cai maduro durante a estação chuvosa.

O presente estudo teve como objetivo comparar a floração e a frutificação das árvores de castanheiras em áreas desmatadas e florestais localizadas nos municípios de Oriximiná e Óbidos, Pará, assim como estudar variáveis ambientais que possam explicar a baixa produção castanheiras observadas em áreas desmatadas. Entre estas estudaram os fatores físicos do solo (compactação, densidade e umidade); 
fatores químicos do solo ( $\mathrm{pH}$ em água, carbono, macronutrientes, capacidade de troca de cátions, saturação de alumínio, matéria orgânica). 0 fenômeno de rebrotação e observação de queimaduras nas árvores foram considerados indicadores de perturbação antrópica. Em definitiva, este estudo alveja contribuir a desvendar os diferentes fatores que podem estar atuando na baixa produção e declínio dos indivíduos de B. excelsa em áreas desmatadas.

\section{MATERIAIS E MÉTODOS}

\section{1. ÁREA DE ESTUDO}

A pesquisa foi realizada na BR-163 conhecida como estrada do BEC (Batalhão de Engenharia e Construção), região pertencente aos municípios de Oriximiná e Óbidos, Pará. A estrada é toda de chão e inicia seu trajeto em direção setentrional na confluência das rodovias PA-439 e PA-254, no município de Oriximiná-PA, $\left(01^{\circ} 34^{\prime} 52,8^{\prime \prime}\right.$ S, $055^{\circ} 44^{\prime} 05,2^{\prime \prime}$ W). A coleta de dados das castanheiras foi realizada em dois sítios de propriedade particular situados na Estrada do BEC: Nova Betel (Oriximiná-PA) e Boa Vista (Óbidos-PA) (Figura 1).

Segundo informantes locais, Nova Betel foi desmatada na década de 1980, e Boa Vista na década de 2000, o que significa que ambas as áreas se diferenciam pelo número de anos em que ficaram desmatadas. Além disso, o sítio de Boa Vista tem atividade pecuária presente na área (com uso frequente do fogo como renovador do pasto), no entanto o sítio de Nova Betel tem sua área desmatada em desuso atualmente.

Figura1: Área de estudo (Estrada do BEC) com a localização dos sítios de Nova Betel e Boa Vista. Mapa adaptado de Renato Glauber (Scoles et al., 2016).

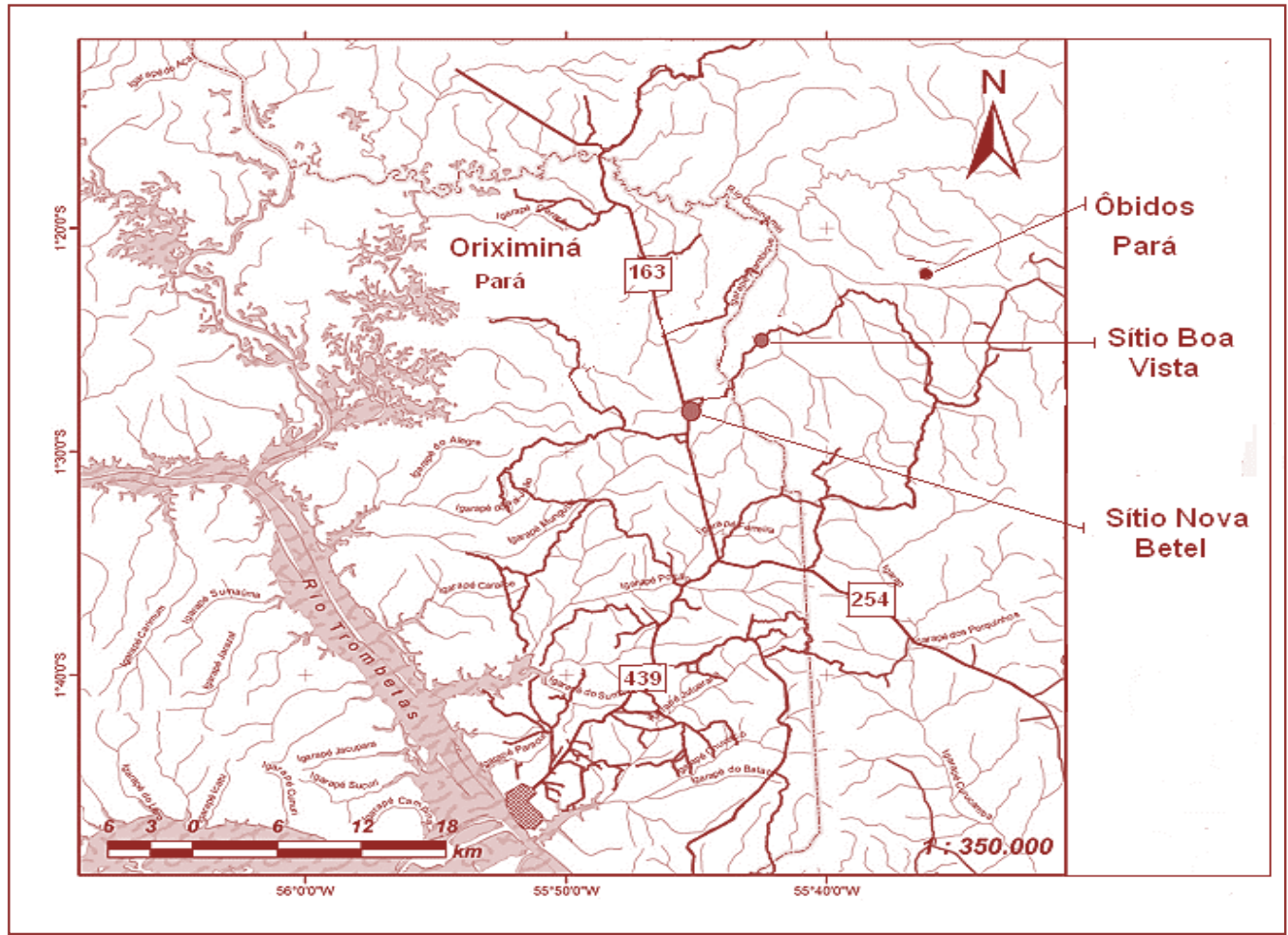

\subsection{COLETA DE DADOS}

Foram medidas 60 árvores em cada sítio, 30 por ambiente área desmatada e florestal, somando um total de 120 árvores monitoradas. As árvores foram selecionadas ao acaso, com uma distância mínima entre as castanheiras de $10 \mathrm{~m}$. Todas as árvores selecionadas tinham evidências de floração e/ou frutificação. Para cada árvore foram feitas as seguintes ações, observações e medições: 1) emplacamento (código, numeração); 2) medição das coordenadas geográficas (latitude, longitude); 3) Circunferência à Altura do Peito (CAP, m), 1,3 m acima do solo; 4) Índice de forma da copa (ic): a) copa inteira, 1; b) 3/4 partes de copa, 0,75 ; c) metade da copa, 0,5; d) uma $1 / 4$ parte da copa, 0,25); e) sem copa 5) medição da projeção de 
dois galhos da copa (90 graus, um do outro) (m), raios da área elíptica da copa ( $\mathrm{r}_{1}$ e $\mathrm{r}_{2}$ ); 6) contagem de frutos (número de frutos/árvore); e flores no chão (número de flores /árvore); 7) distância de árvore de castanheira (m) mais próxima; 8) distância da borda de floresta (m); 9) evidências de perturbação (queimaduras, ocorrência de rebrotação). Todas as medições e/ou observações foram registradas nos dois ambientes a exceção da oitava (8a) variável na ordem supracitada.

\subsubsection{COLETA DAS AMOSTRAS DE SOLO E MENSURAÇÃO DA COMPACTAÇÃO}

Foram coletadas 40 amostras de solo. 0 ponto de coleta foi determinado há $10 \mathrm{~m}$ metros de distância das árvores monitoradas em direção cardinal variável e aleatória. As amostras foram extraídas nas profundidades de 0-40 cm, com uso de trado holandês. Estas amostras foram misturadas com ajuda de balde e pá de jardineiro até ficarem bem homogêneas. As amostras foram analisadas pelo laboratório da Embrapa Amazônia Oriental (Belém) para análise de fertilidade e granulometria seguindo os métodos de EMBRAPA, (2011).

A coleta do solo para quantificar a umidade e densidade foi realizada nos mesmos pontos, nas profundidades $0-40 \mathrm{~cm}$. As amostras destinadas para cálculo da umidade foram pesadas em campo com uma balança de precisão. Para densidade do solo foi usado um anel cilíndrico com volume conhecido. Após isso, as amostras de solo foram secas a $110^{\circ} \mathrm{C}$ por 50 minutos, com uso de estufa de marca Nova Técnica NT514, com aquecimento mínimo de $50^{\circ} \mathrm{C}$ e máximo de $240^{\circ} \mathrm{C}$. 0 processo de secagem e pesagem foi realizado no Laboratório de química do campus universitário de Oriximiná (UFOPA).

As coletas de dados para mensuração da compactação do solo realizaram-se nos mesmos pontos que as amostras de solo $(\mathrm{n}=40)$. A penetração máxima foi de $60 \mathrm{~cm}$ de profundidade utilizando penetrômetro eletrônico (Beutler et al., 2007) cedido pela Embrapa Médio Amazonas (Santarém-PA).

\subsubsection{MONITORAMENTO FENOLÓGICO REPRODUTIVO}

Nos dois sítios, as flores caídas no chão no dia de visita foram contadas no ápice da floração a cada semana de novembro/2014 a março/2015, totalizando 20 visitas, numa área equivalente à projeção da área da copa no chão. A diferenciação das flores que caiam no chão no dia da visita para as que caíram anteriormente foi feita pela coloração, tendo as caídas do mesmo dia uma coloração amarela esbranquiçada, enquanto as do dia anterior um amarelo ferrugem. Os frutos caídos no chão também foram contados de janeiro/2015 a maio de 2015, totalizando 20 visitas.

\subsection{ANÁLISE DE DADOS}

\subsubsection{CÁLCULOS DENDROMÉTRICOS}

O Diâmetro Altura do Peito (DAP) foi calculado a partir da circunferência medida em campo (DAP $=\mathrm{CAP} / \pi$ ). Por sua vez, conforme metodologia de Scoles e Gribel $(2011,2012,2015)$, a área de copa foi calculada multiplicando a superfície elíptica da coroa por um índice de forma de copa. Onde os galhos principais $\left(r_{1}\right.$ e $\left.r_{2}\right)$ foram considerados os raios da elipse, (Equação 1).

$$
\text { Área de copa }=\mathrm{ic} *\left[\pi^{*}\left(\mathrm{r}_{1}{ }^{*} \mathrm{r}_{2}\right)\right]
$$

(Eq. 1)

\subsubsection{ANÁLISE FÍSICO-QUÍMICA DO SOLO}

As amostras de solo foram secas e passadas em peneira fina de $2 \mathrm{~mm}$ de diâmetro. As partículas primárias foram divididas em três grupos de tamanho: areia $(2,00-0,05 \mathrm{~mm})$, silte $(0,05-0,002 \mathrm{~mm}) \mathrm{e}$ argila $(<0,002 \mathrm{~mm})$ para o posterior cálculo das proporções granulométricas seguindo a metodologia de EMBRAPA (2011). As variáveis químicas analisadas foram: pH em água, carbono orgânico (matéria orgânica-M.O.), nutrientes (nitrogênio, cálcio, potássio, fósforo, magnésio), e alumínio trocável. Como principais variáveis mensuráveis da fertilidade do solo foi usada a Capacidade de Troca de Cátions (CTC) efetiva (somatório das concentrações de cátions trocáveis no solo) e a Saturação por bases (\%) (EMBRAPA, 2011). Para calcular a percentagem de umidade do solo em base seca foi utilizado a fórmula Ug = (Mu-Ms) / Ms x 100. Onde: Ug é o conteúdo gravimétrico de água no solo (\% de massa), Mu é a massa úmida da amostra (g), e Ms é a massa seca da amostra (g). 


\subsubsection{TESTES ESTATÍSTICOS}

Efetuaram-se estatística descritiva das variáveis quantitativas estudadas em cada ambiente (área desmatada e área de floresta secundaria). Em seguida, testou-se a normalidade das amostras com teste de Kolmogorov-Smirnov/Lilliefors (Lilliefors, 1967). As variáveis de estudos foram comparadas nos dois ambientes com uso de testes estatísticos de comparações de médias (teste t ou Mann Whitney dependendo do resultado do teste de normalidade). Além disso, analisaram-se correlações entre variáveis produtivas (flores e frutos) e possíveis variáveis explicativas (diâmetro do tronco, área de copa, distância mínima entre árvores e distância com borda de floresta). Para as variáveis binárias de observação (sinais de fogo, rebrotação), usou-se teste Qui-quadrado.

Para detectar os fatores que influenciam na produção de flores e frutos foram feitas regressões múltiplas e simples entre as duas variáveis dependentes do estudo (frutos e flores) e as variáveis independentes (DAP, área de copa). Estas regressões foram feitas usando os dados de todas as castanheiras monitoradas em cada ambiente a exceção da regressão com a variável de distância árvore-borda do castanhal que foi feita unicamente no ambiente desmatado. Quando alguma variável não cumpria normalidade, usou-se o teste de correlação de Spearman.

\section{RESULTADOS}

\subsection{ESTRUTURA POPULACIONAL E DENDROMETRIA}

Das árvores monitoradas, 115 indivíduos apresentaram DAP > 1,0 m (95,8 \%), e 5 árvores DAP < 1,0 m (4,2 \%). A estrutura populacional de castanheiras evidencia um envelhecimento dessas populações com mais de 50\% das árvores com DAP entre 1,3 e 2,0 m. Observa-se também que a grande maioria das castanheiras está no intervalo contínuo de 1,0 a 2,2 m de DAP (89,2 \%). 0 tamanho das árvores foi similar nos dos sítios, e, em cada sítio, não havendo diferenças significativas entre os dois ambientes.

Figura 2. Distribuição de classes diamétricas das castanheiras em intervalos de $10 \mathrm{~cm}$ de DAP em Boa Vista (colunas pretas) e Nova Betel (colunas cinzentas), Estrada do BEC, Noroeste do Pará.

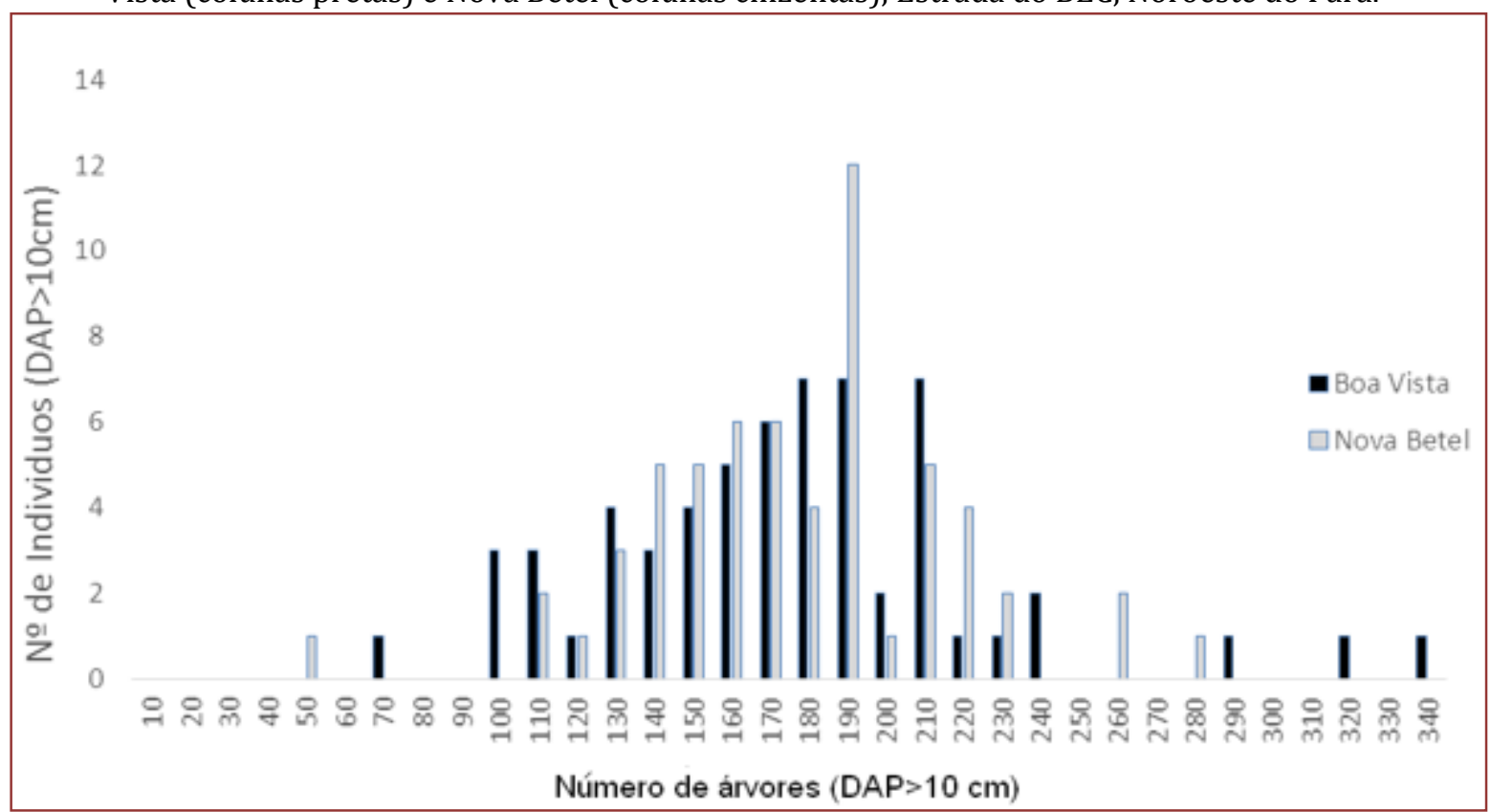




\subsection{DISTÂNCIA ENTRE CASTANHEIRAS E DA BORDA DA FLORESTA}

No Boa Vista as distâncias mínimas entre castanheiras foi significativamente mais alta (teste $t, t=2,0$, $\mathrm{p}=0,01$ ) na área aberta (média de 35,8 $\pm 26,5 \mathrm{~m}$ ) que na área florestal (média de 21,4 $\pm 13,8 \mathrm{~m}$ ) (tabela 1). Na Nova Betel as diferenças não foram significativas (área aberta: 33,4 $\pm 23,5 \mathrm{~m}$; área florestal: $29,7 \pm 19,4$ m) (Tabela 1). Por último, a distância das árvores de castanheira com a borda de floresta foi em média maior no sítio de Boa Vista (41,6 m), do que no sítio de Nova Betel (28,5 m) (Tabela 1).

Tabela 1. Comparação das variáveis químicas (matéria orgânica, pH e fertilidade) e físicas do solo e morfométricas das castanheiras entre área aberta e florestal nos sítios Boa Vista e Nova Betel, Estrada do BEC, Noroeste do Pará.

\begin{tabular}{|c|c|c|c|c|}
\hline & \multicolumn{2}{|c|}{ Sítio Boa Vista } & \multicolumn{2}{|c|}{ Sítio Nova Betel } \\
\hline & Área aberta & Floresta secundária & Área aberta & Floresta secundária \\
\hline $\operatorname{DAP}(\mathrm{m})$ & $1,7 \pm 0,34(2,35 ; 0,91) a$ & $1,7 \pm 0,6(3,37 ; 0,63) \mathrm{a}$ & $1,7 \pm 0,4(2,55 ; 1,01) \mathrm{c}$ & $1,6 \pm 0,3(2,74 ; 0,46) c$ \\
\hline Área da Copa $\left(\mathrm{m}^{2}\right)$ & $554,9 \pm 291,6(1182,31 ; 27,45) a$ & $524,1 \pm 275,7(994,1 ; 16,3) \mathrm{a}$ & $588,3 \pm 278,5(1133,4 ; 84,1) \mathrm{c}$ & $580,0 \pm 264,5(1104,9 ; 142,4) \mathrm{c}$ \\
\hline Distância mínima entre castanheiras (m) & $35,8 \pm 26,4(3: 80) \mathrm{a}$ & $21,4 \pm 13,7(5: 60) \mathrm{b}$ & $33,4 \pm 23,4(8: 116) \mathrm{c}$ & $29,6 \pm 19,3(6: 100) c$ \\
\hline Distância. mínima com a floresta (m) & $41,6 \pm 33,9(5: 150) \mathrm{a}$ & $--a$ & $28,7 \pm 35,1(5: 168) c$ & $-c$ \\
\hline Umidade (\%) & $49,1 \pm 24,2(97,4 ; 20) \mathrm{a}$ & $47,1 \pm 42,1(134 ; 4) \mathrm{a}$ & $34,6 \pm 23,6(77 ; 8) c$ & $43,1 \pm 15,4(72 ; 20) c$ \\
\hline Concentração de areia total $(\mathrm{g} / \mathrm{Kg})$ & $600,2 \pm 119(775 ; 388) a$ & $666,4 \pm 26,9(703 ; 632) a$ & $694,8 \pm 68,5(821 ; 594) \mathrm{c}$ & $593,3 \pm 179,7(752 ; 328) c$ \\
\hline Concentração de argila total (g/Kg) & $154 \pm 26,7(200 ; 120) \mathrm{a}$ & $190 \pm 31,6(240 ; 140) \mathrm{b}$ & $170 \pm 64,1(240 ; 20) \mathrm{c}$ & $128 \pm 42,3(220 ; 60) c$ \\
\hline Matéria orgânica $(\mathrm{g} / \mathrm{Kg})$ & $19,1 \pm 7,5(38,3 ; 12,4) a$ & $19,4 \pm 5,3(32,7 ; 13,8) \mathrm{a}$ & $17,6 \pm 13,9(22,5 ; 12,0) \mathrm{c}$ & $23,2 \pm 8,3(37,3 ; 13,5) c$ \\
\hline $\mathrm{pH}$ & $5,04 \pm 0,4(5,8 ; 4,5) a$ & $4,9 \pm 0,1(5,2 ; 4,7) \mathrm{a}$ & $5,2 \pm 0,6(7 ; 4,7) \mathrm{c}$ & $4,8 \pm 0,2(5,3 ; 4,5) \mathrm{c}$ \\
\hline Fósforo & $4,8 \pm 1,9(10 ; 4)$ & $6,5 \pm 1,4(8 ; 4)$ & $15,2 \pm 30(95 ; 4)$ & $5,1 \pm 1,7(7,2) \mathrm{d}$ \\
\hline $\mathrm{N} \%$ & $0,7 \pm 0,2(1,2 ; 05) \mathrm{a}$ & $0,7 \pm 0,1(0,9.06) \mathrm{a}$ & $0,6 \pm 0,1(0,8 ; 0,4) \mathrm{c}$ & $0,8 \pm 0,2(1,2 ; 0,5) d$ \\
\hline $\mathrm{Ca}+\mathrm{Mg}\left(\mathrm{cmolc} / \mathrm{dm}^{3}\right)$ & $1,2 \pm 0,8(2,5 ; 0,3) \mathrm{a}$ & $0,4 \pm 0,3(0,7 ; 0,2) b$ & $1,26 \pm 1,1(4 ; 0,3) \mathrm{c}$ & $1 \pm 0,2(1,4 ; 0,6) \mathrm{c}$ \\
\hline $\mathrm{H}+\mathrm{Al}\left(\mathrm{Cmolc} / \mathrm{dm}^{3}\right)$ & $3,9 \pm 1,2(5,45 ; 1,82) \mathrm{a}$ & $4,5 \pm 0,7(6,27 ; 3,8) \mathrm{a}$ & $2,8 \pm 1,0(3,8 ; 08) c$ & $4,7 \pm 2,0(7,9 ; 2,6) \mathrm{d}$ \\
\hline CTC/Efetiva(Cmolc/ $\left.\mathrm{dm}^{3}\right)$ & $2,7 \pm 0,6(3,6 ; 1,9) \mathrm{a}$ & $1,9 \pm 0,2(2,3 ; 1,49) \mathrm{b}$ & $2,3 \pm 0,7(4,2 ; 1,56) \mathrm{c}$ & $3,2 \pm 1,6(5,52 ; 1,7) \mathrm{c}$ \\
\hline Saturação base (V\%) & $26,9 \pm 13,5(53,4 ; 8,5) a$ & $10,1 \pm 1,6(12,59 ; 6,73) \mathrm{b}$ & $33,2 \pm 24,0(70,52 ; 9,05) \mathrm{c}$ & $21,4 \pm 7,8(32,79 ; 9,09) \mathrm{c}$ \\
\hline Saturação Al (m\%) & $47,2 \pm 25,3(83,91 ; 8,7) a$ & $73,22 \pm 4,4(80,77 ; 65,04) \mathrm{b}$ & $42,96 \pm 32,4(78,84 ; 2,4) \mathrm{c}$ & $56,88 \pm 19,3(85,27 ; 30,9) c$ \\
\hline Tipo de textura & Franco arenoso & Franco arenoso & Franco arenoso & Franco argilo arenosa \\
\hline
\end{tabular}

Nota: Valores médios e seu desvio padrão, em parêntese as mínimas e as máximas. Letras diferentes entre tratamentos indicam diferença significativa $(\mathrm{p}<0,05)$ : Boa Vista $(a, b)$ e Nova Betel $(c, d)$.

\subsection{FATORES FÍSICOS DO SOLO}

Os solos das áreas abertas foram mais compactados que as áreas florestais (Boa Vista, teste de Mann Whitney $U=24, p=0,0165$; Nova Betel teste de Mann Whitney $U=31,5 ; p=0,0569$ ). 0 maior grau de compactação do solo foi registrado na área aberta do sítio Boa Vista (resistência a penetração de $10.928,3 \pm 6.558 \mathrm{kPa} / \mathrm{mm}$ ). Neste local, a resistência de penetração foi em média quase quatro vezes superior a área aberta de Nova Betel $(2.779 \pm 4.300 \mathrm{kPa} / \mathrm{mm})$ e mais de cinco vezes superior as resistências registradas nas duas áreas florestais (Figura, 3).

A densidade do solo foi maior na área aberta que na área de floresta, tanto no Boa Vista como em Nova Betel (Figura 3). A diferença de densidade do solo entre os dois ambientes foi significativa unicamente no sítio Boa Vista (Figura, 3). A umidade do solo variou de 34\% a 49\%. Não tiveram diferenças significativas entre os dois ambientes. (Tabela 1).

A textura dos solos mostrou maior presença de areia $(60 \pm 59,3 \%)$, seguido pela fração de argila $(15,4 \pm 26 \%)$ (Tabela 1). Não foram detectadas diferenças significativas de concentração de areia entre as áreas desmatadas e florestais para ambos os sítios. A concentração de argila variou em média de 128 g/Kg (área florestal, Nova Betel) até 190 g/Kg (área florestal, Boa Vista). Comparando os dois ambientes, as diferenças de concentração de argila foram significativas em Boa Vista (mais argila na área florestal, teste $\mathrm{t}, \mathrm{t}=2,1, \mathrm{p}=0132$ ). 
Figura 3: Comparação da resistência a penetração e densidade entre área aberta e florestal, nos sítios Boa Vista e Nova Betel Estrada do BEC, BR-163, Noroeste do Pará. Valores representam médias \pm erro padrão da média. Letras diferentes entre tratamentos indicam diferença significativa $(\mathrm{p}<0,05)$.

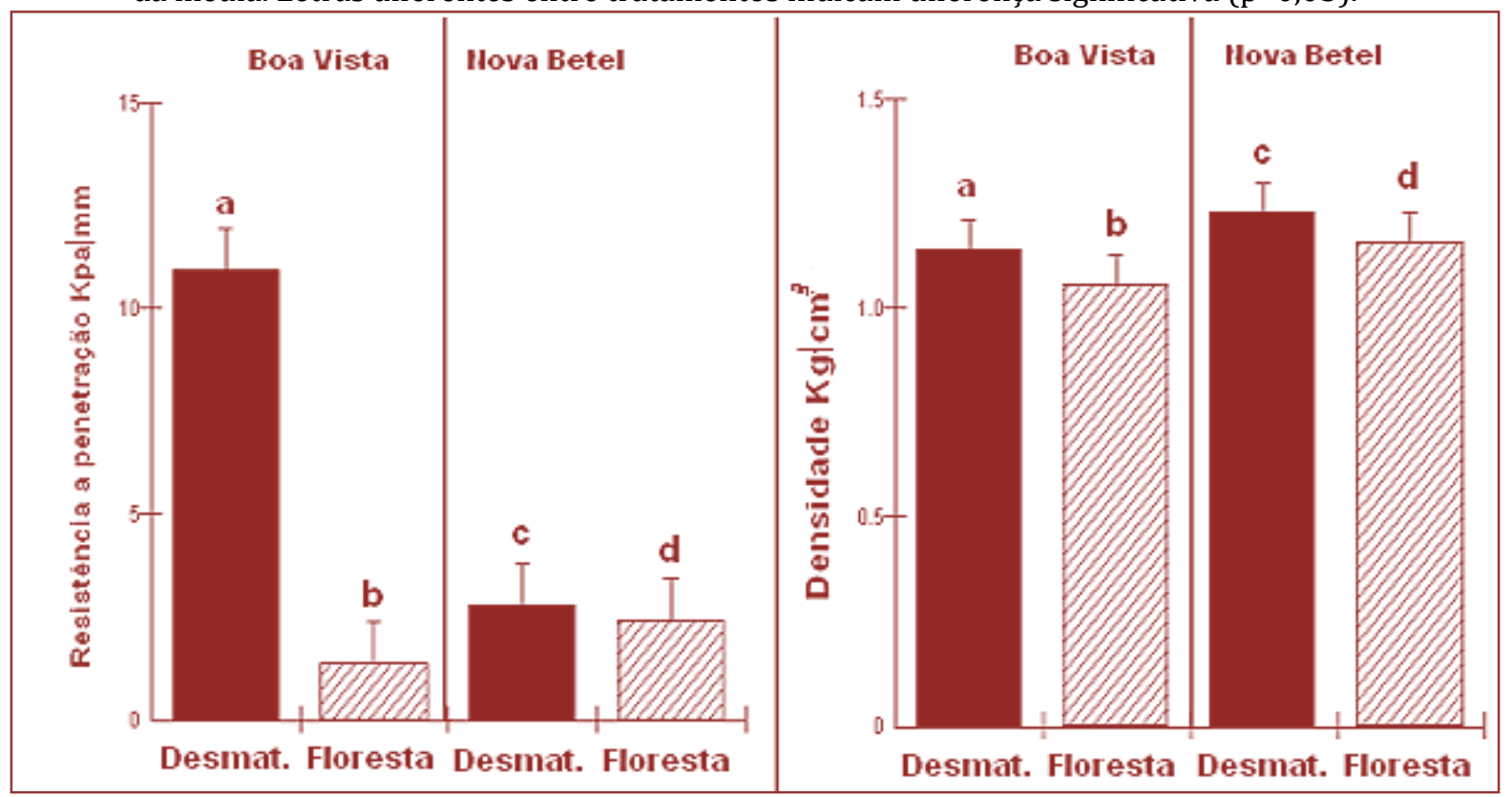

\subsection{FATORES QUÍMICOS DO SOLO}

Em relação às propriedades químicas do solo, os resultados das análises mostraram que no sítio Boa Vista a concentração de matéria orgânica é muito parecida entre os dois ambientes, ao contrário do de Nova Betel em que a concentração de matéria orgânica foi superior na área de floresta $(23,2 \pm 8,3 \mathrm{gr} / \mathrm{Kg})$ em relação a área aberta $(17,7 \pm 8,3 \mathrm{gr} / \mathrm{Kg}$ ) (Tabela 1), diferenças não significativas estatisticamente, mas que revelam uma tendência a diferenciação. Em termos gerais, os solos das áreas desmatadas foram levemente menos ácidos ( $\mathrm{pH}$ de 5,01 e 5,25) comparados com os solos das áreas florestais $(\mathrm{pH}, 4,81$ e $4,97)$ mas as diferenças não foram significativas (Tabela 1).

Não teve diferenças significativas entre os ambientes para fósforo (Tabela 1). 0 percentual de nitrogênio apresentou diferenças significativas no sítio Nova Betel a favor da área de floresta e a concentração de cálcio e magnésio no sítio Boa Vista, desta vez a favor da área aberta (tabela 1). Entretanto, quando se comparou a concentração de alumínio e hidrogênio nos dois sítios de estudo, as áreas de floresta registram maiores teores destes elementos, especialmente no sítio Nova Betel (teste $t, t=2,1, p=0,0173$, Tabela 1). No sítio Boa Vista a CTC foi significativamente superior na área desmatada em relação a área florestada (teste $\mathrm{t}=2,1, \mathrm{p}=0,0007$ ), por contra, no sítio Nova Betel a área florestada apresentou teores mais altos de CTC ainda que as diferenças não foram significativas (Tabela 1). Por último, as duas áreas desmatadas registraram maior saturação por bases e menor saturação por alumínio em relação a suas respetivas áreas de floresta (Tabela 1 ).

\subsection{FATORES DE PERTURBAÇÃO EXTERNA: SINAIS DE FOGO E REBROTAÇÃO NOS SÍTIOS INVENTARIADOS}

0 percentual de árvores com sinais de queimadura no tronco foi significativamente mais alto nas áreas desmatadas que nas áreas florestais nos dois sítios: Boa Vista (área desmatada: 63,3\%; área florestada: 23,3\%, Qui Quadrado, p=0,0017) e Nova Betel (área desmatada: 26,7\%; área florestada: 6,7 teste QuiQuadrado, $\mathrm{p}=0$,0373). No sítio de Boa Vista, a rebrotação não mostrou diferenças significativas entre os dois ambientes (20\% das árvores com rebrota na área desmatada por 10\% na área florestal). Em Nova Betel, a rebrotação foi quase insignificante nos dois ambientes, com uma única árvore com rebrote na área desmatada $(3,3 \%)$. 


\subsection{VARIÁVEIS PRODUTIVAS: FLOR E FRUTO}

A produção de flores foi significativamente maior (mais de 4 vezes) nas áreas florestadas nos dois sítios estudados (teste $t, t=1,98 ; p<000,1$; Figura 4). De igual forma, o número de frutos na área desmatada foi significativamente menor que na área florestada nos dois sítios (teste $t, t=2,0, p<0,0001$, figura 4). Em média, a produção de frutos na área de floresta foi 21 vezes maior que na área desmatada no sítio Boa Vista e 24 vezes maior no sítio da Nova Betel.

Figura 4: Comparação da produção de flores e frutos entre a área aberta e florestal nos sítios Boa Vista e Nova Betel, Estrada do BEC, Noroeste do Pará. Valores representam médias \pm erro padrão da média. Letras diferentes entre tratamentos indicam diferença significativa $(p<0,05)$.

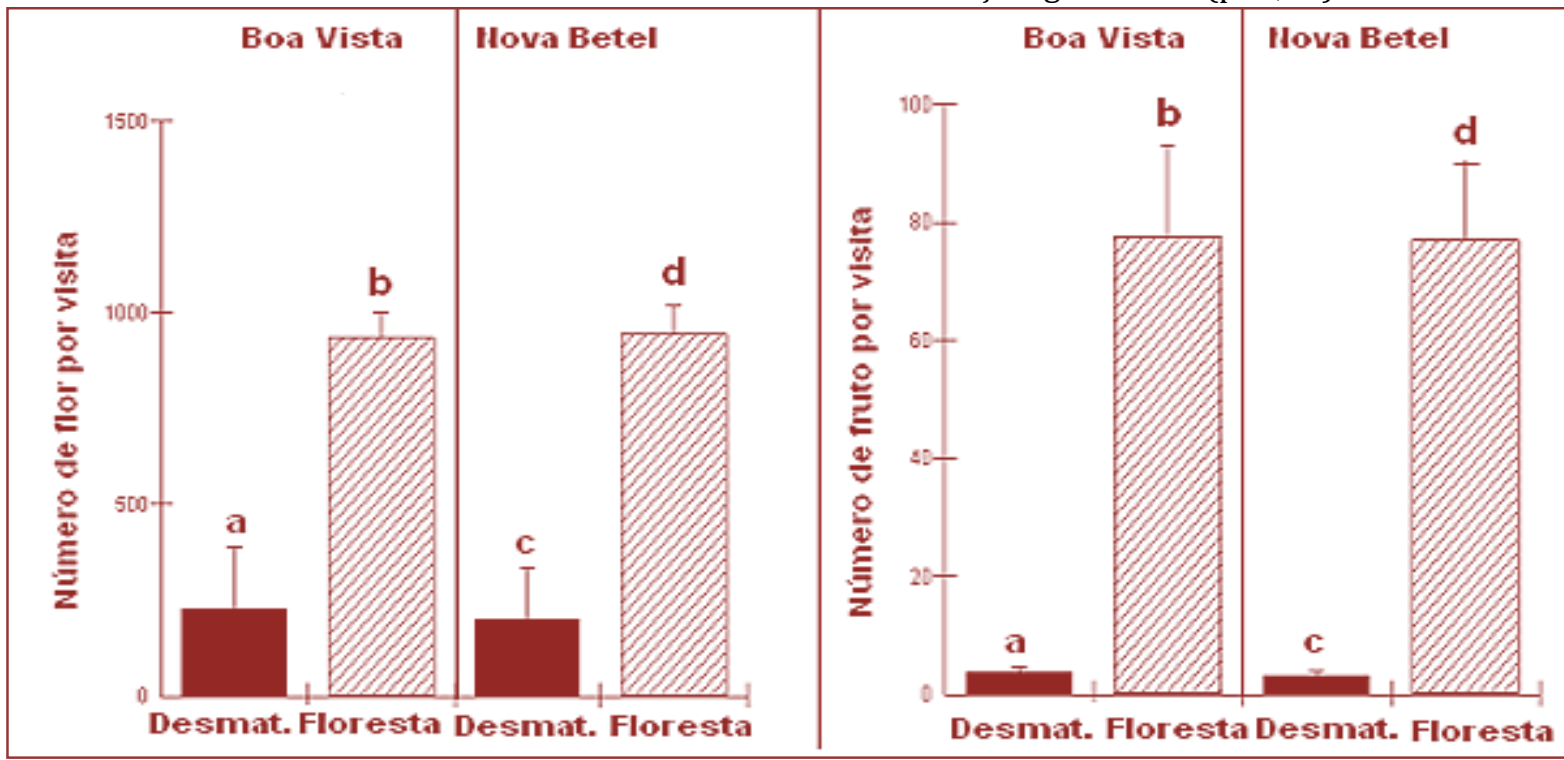

\section{DISCUSSÃo}

\subsection{ESTRUTURA POPULACIONAL E DENDROMETRIA}

A estrutura populacional das castanheiras monitoradas na Estrada do BEC nos indica que a população de castanheiras vivas na área de estudo está envelhecida, com domínio das classes diamétricas com DAP $>1$ $\mathrm{m}$ nos dois sítios e nos ambientes. Além disso, a estrutura populacional é dominada por classes de árvores nos intervalos de diâmetro de 1,3 e 2,0 m, com pouca presença de árvores com tamanho de diâmetro < 1 m., fato que já foi observado na mesma área de estudo (Scoles et al., 2016) e em outros locais próximos com ocorrência abundante de castanheiras (Salomão, 2009; Scoles e Gribel, 2012). A baixa regeneração tem sido registrada na região do rio Trombetas, situação que parece ser mais crítica em áreas intensamente transformadas como as deste estudo (Scoles e Gribel, 2012; Scoles et al., 2016). Nesta pesquisa, a população de castanheiras nos dois ambientes apresentou características dendrométricas parecidas (tamanho da árvore e área de copa), descartando assim que as diferenças de produção entre os dois ambientes seja causada por estes fatores. Não se detectou diferenças significativas de tamanho de diâmetro entre a área aberta e área florestal nos dos sítios pesquisados (tabela 1). Da mesma forma, as variações de área de copa não foram significativas entre os dois tratamentos comparados (intervalos médios entre 524 e $588 \mathrm{~m}^{2}$ de área de copa por árvore, tabela 1).

\subsection{DISTÂNCIA ENTRE CASTANHEIRAS E DA BORDA DA FLORESTA}

A distância mínima entre castanheira foi significativamente maior na área desmatada unicamente no sítio de Boa Vista, o que mostra, neste local, um maior isolamento das árvores, ou seja, as árvores estão mais distantes umas das outras quando comparadas às das áreas florestais adjacentes. Maior distanciamento entre árvores poderia influenciar negativamente na polinização da castanheira já que nestes casos se pressupõe uma maior permanência das abelhas na mesma árvore dificultando assim a fecundação cruzada da planta (Muller et al., 1980; Maués, 2002). Ainda assim, precisa-se relativizar estes resultados comparativos, pois a distância média mínima foi de 35 metros na área desmatada em Boa 
Vista, recorrido potencialmente baixo para os padrões voadores das abelhas polinizadores da castanheira (Janzen, 1971; Maués, 2002) e dos valores de dispersão média de pólen registrados no Acre (945 m para floresta, $422 \mathrm{~m}$ para pastagem; Silva, 2014).

\subsection{FATORES FÍSICOS DO SOLO}

Os solos da área de estudo são arenosos e não apresentaram diferenças significativas de textura entre os dois ambientes. Os resultados mostraram claramente que as áreas de pastagens apresentaram maior grau de compactação que as áreas de florestas. Os dados registrados nesse estudo corroboram com outros trabalhos em que área de pastagem apresentou maior grau de compactação do que as áreas de florestas (Muller et al., 2001; Martinez e Zinck, 2004). Esta maior compactação do solo dificultaria a ação radicular das plantas em áreas degradadas e de pastagem (Muller et al., 2001; Araújo, 2011), e também o fluxo de água e nutrientes que poderia contribuir a um aumento de erosão do solo e uma redução nas atividades biológicas das árvores neste ambiente.

Neste estudo, a diferença na resistência a penetração foi mais acentuada na área desmatada do sítio Boa Vista, isso, provavelmente, se explica por ser uma área de intensa pastagem, com frequente pisoteio do gado e não apresentar cobertura vegetal (Lanzanova, 2005). Entretanto, no sítio Nova Betel as atividades pecuárias diminuíram muito nos últimos anos explicando a menor compactação do solo e menores diferenças com área florestal próxima. Estas diferenças de compactação entre ambientes repetem-se na densidade do solo, ainda que neste caso as diferenças foram significativas no sítio Boa Vista (maior densidade em áreas desmatadas). Novamente, os resultados desta pesquisa coincidem com de outros trabalhos que mostram maior compactação e densidade de solos em áreas desmatadas em relação a áreas florestais e sugerem que aumentos de compactação comportam também incrementos da densidade e diminuição da porosidade dos solos (Muller et al., 2001; Souza et al., 2004; Reichert et al, 2007).

0 trabalho não evidenciou diferenças de umidade de solo entre as duas áreas comparadas (desmatado e floresta), possivelmente porque a coleta de solo foi feita durante a estação chuvosa do ano, outros estudos também não encontraram diferenças significativas no teor de umidade entre áreas queimadas e não queimadas (Meirelles, 1990).

\subsection{FATORES QUÍMICOS DO SOLO}

Em relação a estrutura química do solo os teores de matéria orgânica mostraram similitudes entre os dois ambientes, as áreas de floresta tiveram concentrações maiores de matéria orgânica só em Nova Betel. Na floresta a produção de matéria orgânica é maior e encontra-se em condições apropriadas de temperatura e umidade típicas da região; diferente da área desmatada de pastagem com menor produção de liteira (matéria orgânica morta) e onde o fogo consome toda a matéria orgânica. Não obstante, em ambos os casos, estas diferenças não foram significativas, sugerindo que a matéria orgânica é altamente móvel da floresta à área desmatada ou que as áreas de pastagem têm uma cobertura arbustiva capaz de suprir a matéria orgânica, fato já observado na Amazônia (Moreno et al. 2012). Além disso, é comum ver aumentos de matéria orgânica em pastos derivados de floresta derrubada na Amazônia (Neill et al., 1997, Cerri et al., 2003, Cerri et al., 2004, Araújo et al., 2011) devido à grande capacidade do capim acrescentar matéria orgânica ao solo através das raízes.

Neste estudo, os solos das áreas de floresta tiveram indicadores de fertilidade mais baixos que nas áreas desmatadas: maiores percentuais de saturação de alumínio, menor capacidade de troca catiônica, menor concentração de cálcio e magnésio e menor saturação de bases. Ainda assim, as diferenças de fertilidade entre os dois ambientes foram significativas unicamente no sítio Boa Vista. Neste, a maior concentração de cálcio e magnésio nas áreas desmatadas ocorre pela mineralização desses nutrientes devida a ação do fogo (Moreno et al. 2012), fato que não se repete no sítio de Nova Betel, onde não houve diferença significativa entre os dois ambientes.

O nitrogênio apresentou diferença significativa no Sítio Nova Betel, com valores maiores na floresta. Entende-se que na floresta esses macronutrientes dependem essencialmente da reciclagem interna da floresta e a liteira fina representa a sua maior entrada para o ecossistema florestal (Luizão et al, 2007). Por contra, no Sítio Boa Vista não houve diferença significativa de nitrogênio entre os dois ambientes, provavelmente as áreas desmatadas mais velhas tenham perdido mais nitrogênio no decorrer do tempo devido à ausência de uma camada de liteira na superfície do solo, embora esta não foi quantificada neste estudo. Em contraste, nos dois sítios, a concentração de fósforo disponível foi baixa $\left(<10 \mathrm{mg} / \mathrm{dm}^{3}\right.$, Cravo 
et al., 2007) sem registrar diferenças significativas entre os dois ambientes. Estes resultados são esperados em solos ácidos e arenosos da região da Amazônia, pois geralmente este macronutriente é limitante nestes ambientes (Koerselman \& Meuleman, 1996; Novais e Smith, 1999).

Os solos analisados podem ser considerados como ácidos (pH entre 4,5-5,4) com pH ligeiramente superior nas áreas desmatadas, devido provavelmente pelos compostos básicos presentes nas cinzas que corrigem esse pH, e aumenta a concentração de nutrientes (Moreno et al, 2012). Entretanto, estas diferenças de acidez edáfica não foram significativas. Em contraste, a concentração de $\mathrm{H}+\mathrm{Al}$, no sítio de Nova Betel, foi significativamente maior na área de floresta que na área desmatada de pastagem, o que apontaria que é efetivamente a ação do fogo que causa a correção do pH, resultante do aumento da concentração de bases presentes nas cinzas (Ulery et al,1993). Neste estudo, os solos das duas áreas tropicais podem ser classificados de muito pobres, pois a saturação de alumínio (m\%) foi > 50\% (Ronquim, 2010). Ainda que a saturação por alumínio seja significativamente menor nas áreas desmatadas que nas florestadas, a fertilidade continua sendo considerada baixa nos dois ambientes, pois os limites de saturação por bases está muito abaixo do mínimo recomendado que é V\% 250 (Cravo et al., 2007; Ronquim, 2010).

Em geral, os solos de pastagem (áreas desmatadas) e com uso frequente do fogo como é o caso do sítio Boa Vista têm a capacidade de disponibilizar nutrientes no solo através da mineralização e por isso apresentam características químicas menos desfavoráveis em termos de fertilidade quando comparados aos solos florestais tropicais (Fearnside e Leal Filho, 1993; Knicker, 2007; Moreno et al, 2012). Além disso, a presença de gado nestas áreas favorece a fertilização do solo mediante deposição de grandes quantidades de excrementos.

Entretanto, ainda que as condições de fertilidade dos solos florestais possam ser mais desfavoráveis que em áreas desmatadas, nesses ecossistemas, a entrada de nutrientes é garantida mediante a decomposição rápida de matéria orgânica na camada de "serapilheira" ou liteira, feita pela microbiota existente em condições ambientais favoráveis (umidade e temperatura alta). No entanto, nas áreas de pastagem o solo pouco fértil, com médias de 27\% (sítio Boa Vista) e 33\% (sítio Nova Betel) de saturação de bases, ainda que mais fértil que o solo florestal, não tem a quantidade de liteira que tem a floresta (embora esta não fosse quantificada neste estudo) e a perda de nutrientes deve ser mais rápida pela alta exposição dos solos a lixiviação devido ao tipo de solo que apresenta textura arenosa (Fearnside e Leal Filho, 1993; Luizão et al., 2007).

Em resumo, quando se compara as variáveis físicas e químicas dos solos tropicais em áreas florestais e desmatadas (com uso mais ou menos frequente do fogo), as diferenças mais fortes são em relação às variáveis físicas (compactação, densidade e umidade), mais desfavoráveis em geral nos solos de áreas desmatadas. Já as variáveis químicas foram mais semelhantes e inclusive mais favoráveis nas áreas desmatadas e com uso de fogo que disponibiliza esses nutrientes para o solo, principalmente quando as queimadas são frequentes. 0 solo menos ácido e mais rico em nutrientes se explica em função das cinzas possuírem alta concentração de alguns desses macronutrientes, por exemplo, N, P, K, Ca e Mg (Soares, 1990; Knicker, 2007).

\subsection{FATORES DE PERTURBAÇÃO EXTERNA}

O fogo age sobre o estrato arbóreo, influenciando, sobretudo na redução do porte das árvores (Ramos; Rosa, 1996) e da composição florística e estrutura da vegetação (Lopes et al., 2009). Neste estudo, a frequência de árvores queimadas foi significativamente maior em áreas desmatadas nos dois sítios, resultado do uso do fogo para limpeza da vegetação rasteira em áreas de pastagens. As castanheiras localizadas nas áreas desmatadas mostraram razoável capacidade de rebrotar, o que evidencia capacidade de resistência desta espécie às perturbações antrópicas, corroborando observações e resultados de outros trabalhos da literatura (Paiva et al., 2011; Scoles et al., 2011, 2014).

\subsection{PRODUÇÃO DE FLORES E FRUTOS}

As diferenças de produção de flores e frutos foram altamente significativas nos dois sítios (Boa Vista e Nova Betel) em favor das áreas florestais. A baixa produção de castanheiras em áreas degradadas comparadas com populações de castanheiras em áreas florestais adjacentes confirma trabalhos anteriores em Marabá (Kitimura e Muller, 1984) e Estrada do BEC (Oriximiná/Óbidos; Scoles et al., 2016). Tem sido propostas várias hipóteses para explicar a baixa produção das castanheiras em áreas 
desmatadas à maioria delas supõe que existe uma ineficiência quantitativa ou qualitativa das visitas dos polinizadores (Kitimura e Muller 1984, Vaissière et al., 2009). Recentes estudos têm mostrado que os potenciais polinizadores da castanheira estão presentes em ambientes desmatados (Wadt et al., 2016) o que deixaria em aberto a possibilidade de ser outros fatores ambientais os que explicassem a baixa produção da castanheira nesses locais. Neste estudo, não foram observadas correlações significativas entre produção de flores ou frutos e as duas variáveis dendrométricas mensuradas (tamanho da árvore e área da copa). Tão pouco observou-se associações significativas entre a distância mínima entre castanheira com a produção de flores ou de frutos em nenhuma das duas áreas de paisagem pesquisada (não obstante em um sítio a população de castanheira em área desmatada tem a vizinhança mais distante, veja ressalva no item 4,2). Igualmente não houve correlação entre produção de flores e frutos em nenhum dos ambientes e sítios. Entretanto $100 \%$ das árvores de castanheiras nas áreas desmatadas apresentaram flores, destas $88,33 \%$ apresentaram frutos confirmando a ocorrência da polinização. Os resultados corroboram com estudos de que ocorre polinização nas populações de castanheiras em áreas desmatadas (Cavalcante, 2008; Silva, 2014; Wadt et al, 2016).

No Estado do Acre, Wadt et al. (2008) e Kainer et al. (2007) comprovaram uma relação positiva entre área de copa com produção de frutos, fato não confirmado neste estudo. Entretanto, neste trabalho foi possível relacionar tamanho da árvore (DAP) com produção de frutos na área de floresta, mas não na área desmatada. Ou seja, o tamanho da árvore não se mostra determinante em áreas desmatadas para a produção de frutos, provavelmente porque variáveis ambientais são mais importantes e limitam a produção em áreas desmatadas. Destaca-se também que a produção de frutos contabilizada nas áreas florestais deste estudo foi muito similar as médias produtivas de 140 árvores monitoradas durante sete anos no Estado do Acre, 71,3 ( $\pm 74,4)$ frutos por árvore (Wadt et al.,2005; Kainer et al, 2007).

Quais fatores ambientais poderiam explicar a baixa produção das castanheiras nas áreas desmatadas? Esse trabalho registrou duas causas importantes que poderiam explicar as diferenças de produção da castanheira entre as áreas desmatadas e florestais adjacentes: grau de compactação do solo e sinais de perturbação antrópica repetida (fogo) corroborando o achado em outros estudos (Fearnside e Barbosa, 1998; Muller et al, 2001; 2004; Reicher et al, 2007; Nepstad et al 2011). É importante destacar que isso ocorre apesar dos solos das áreas desmatadas terem apresentado maior fertilidade que os solos florestais. Ou seja, a compactação do solo e as queimadas repetidas devem debilitar de tal forma as plantas florestais nas áreas de pastagem, que estas acabam não se beneficiando desse maior teor de macronutrientes (Muller et al., 2001; Araújo, 2011).

Fica irresoluto o motivo de não correlação entre produção de frutos e flores na área de floresta, pois supostamente nos ambientes florestais a presença e visita dos polinizadores deveriam estar garantidas, mas muitas espécies tropicais têm a estratégia reprodutiva de produzir muito mais flores que frutos de tal modo a atrair a maior quantidade de polinizadores e segurar o sucesso reprodutivo através da exportação de pólen (Auspurger 1983; Montalvo \& Ackerman 1987; Sutherland 1987).

Contudo, sugerem-se novas pesquisas sobre este assunto que objetivem relacionar a baixa produção de flores e frutos de castanheiras em áreas desmatadas estudando outros fatores ambientais (variações microclimáticas), monitorando respostas fisiológicas das árvores provocadas pelo estresse ambiental (perturbações frequentes, solo compactado, ambiente mais seco e quente, etc.) e pesquisando o comportamento dos polinizadores nas áreas desmatadas e florestais adjacentes.

A castanheira é uma espécie protegida por lei (Brasil, 2006), por isso é uma feição proeminente das áreas de pastagens, às vezes sendo a única árvore no meio da vegetação rasteira. Embora sobrevivam em um ambiente desfavorável, árvores isoladas cumprem várias funções ecológicas: área de refúgio para pássaros e insetos, doador de pólen para castanheiras próximas, manutenção da diversidade gênica em nível da paisagem e sombra para o gado, entre outros serviços ambientais (Guevara et al.1992; Harvey e Haver 1999; Manning et al. 2006), o que justifica tomar medidas de manejo que garantam sua preservação. Entre estas medidas sugerem-se: 1) maior e mais eficiente fiscalização da área por parte dos órgãos públicos competentes para evitar a derrubada ilegal da castanheira; 2) políticas públicas e assistência técnica (serviço de extensão) aos proprietários e usuários da área, para beneficiar-se das castanheiras que incentive a conservação delas dentro da pastagem; 3 ) adoção de práticas de manejo do solo e uso restrito do fogo nas áreas de ocorrência da castanheira com a finalidade de descompactar o solo e evitar as queimadas repetidas; 4) maior rotação do gado nas áreas ativas de pastagem 5) incentivo para que a recomposição de áreas de reserva legal e preservação permanente sejam designadas preferencialmente em áreas com castanheiras remanescentes. 


\section{CONCLUSÃO}

Os resultados mostrados nesse estudo comparativo com castanheiras localizadas em dois ambientes diferentes (área desmatada e área florestal) confirmaram que a produção de frutos e flores foi significativamente menor nas áreas desmatadas. Como potenciais agentes causadores destas diferenças, relevaram-se duas variáveis em áreas desmatadas: 1) maior compactação do solo; 2) maior frequência de perturbação pelo fogo.

Estes resultados não excluem a importância de outros aspetos ecológicos não estudados nesta pesquisa como polinização escassa ou ineficiente das árvores isoladas ou piores condições microclimáticas (menor disponibilidade de água, maior temperatura ambiente). Por último, destaca a necessidade de práticas de manejo de solo e medidas ativas de proteção das castanheiras em áreas desmatadas com a finalidade da sobrevivência e reprodução das árvores remanescentes em áreas que provém importantes serviços ecológicos.

\section{REFERÊNCIAS}

[1] ARAUJO, E. A.; KER, J. C.; MENDOÇA, E. S.; SILVA, I. R. Impacto da conversão floresta - pastagem nos estoques e na dinâmica do carbono e substâncias húmicas do solo no bioma Amazônico. Acta Amazônica. 41(1): 103-114, 2011.

[2] AUGSPURGER, C. K. Phenology, Flowering Synchrony, and Fruit Set of Six Neotropical Shrubs. Biotropica. 15, $257-267,1987$

[3] BEUTLER, A. N.; CENTURION, J. F.; SILVA, A. P. Comparação de penetrômetro na avaliação da compactação de Latossolos. Eng. Agríc. v.27, n.1, p.146-151, 2007.

[4] BRASIL. Decreto Federal n. 1.228, de 19 de outubro de 1994 [online]. Diário Oficial da República Federativa de Brasil, Brasília, DF (1994 out 20), 1994. Disponível em: http://presrepublica.jusbrasil.com. br/legislacao/109608/decreto-1282-94.

[5] BRASIL. Decreto n. 5.975, de 30 de novembro de 2006. Diário Oficial da República Federativa de Brasil, Brasília, DF (2006 dez 01); Sec. 1, p.1-3, 2004.

[6] CAVALCANTE, M. C. Visitantes florais e polinização da castanha-do-brasil (Bertholletia excelsa H.\&B.) em cultivo na Amazônia central. Dissertação (mestrado) Universidade Federal do Ceará, Fortaleza. 36, 2008.

[7] CAVAlCANTE, M. C.; OLIVEIRA, F. F.; MAUES, M. M.; FREITAS, B. M. Pollination Requirements and the Foraging Behavior of Potential Pollinators of Cultivated Brazil Nut (Bertholletia excelsa Bonpl.).Trees in Central Amazon Rainforest. Psyche. v. 2012, Article ID 978019, p. 1-9, 2012.

[8] CERRI, C. E.P.; COLEMAN, K.; JENKINSON, D. S.; BERNOUX, M.; VICTORIA. R.; CERRI, C. C. Modeling soil carbon from forest and pasture ecosystems of Amazon, Brazil. Soil Sci. Soc. Am. J. 67, 1879-1887, 2003.

[9] CERRI, C. E. P.; PAUSTIAN, K.; BERNOUX, M.; VICTORIA, R. L.; MELLILO, J.M.; CERRI, C. C. Modelling changes in soil organic matter in Amazon forest to pasture conversion, using the Century model. Glob. Change Biol. 10,815$832,2004$.

[10] CRAVO, M. S.; VIEGAS, I. J. M.; BRASIL, E. C. Recomendações de adubação e calagem para o Estado do Pará. Belém: Embrapa Amazônia Oriental. 1a edição, v. 01, 2007, 262p, 2007.

[11] DAVIDSON, E. A.; ARAÚJO, A. C.; ARTAXO, P.; BALCH, J. K.; BROWN, I.F.; BUSTAMANTE, M. M. C. et al. The Amazon basin in transition. Nature. v. 481, p.321-328, 2012.

[12] EMBRAPA - Empresa Brasileira de Pesquisas Agropecuárias, Manual de Métodos de Análise de Solo: 1-212. 3ํㅡㄹ edição, Rio de Janeiro: EMBRAPA-CNPS, 2011

[13] EMBRAPA Empresa Brasileira de Pesquisas Agropecuárias, Manual de análises químicas de solos, plantas e fertilizantes: Brasília, DF: Embrapa Solos. 270 p, 2011.

[14] FEARNSIDE, P. M.; LEAL FILHO. N.; FERNANDES, F. M. Rainforest burning and the global carbon budget: Biomass, combustion efficiency and charcoal formation in the Brazilian Amazon. J. Geophys. Res. Atmos. 98D9, 1673316743, 1993.

[15] FEARNSIDE, P. M.; BARBOSA, R. I. Soil carbon changes from conversion of forest to pasture in Brazilian Amazonia. Forest Ecology and Management. 108. p 147-166, 1998.

[16] FEARNSIDE, P. M. Consequências do desmatamento da Amazônia. Scientific American. Brasil Especial Biodiversidade, p. 54-59, 2010.

[17] FERREIRA, L. V. Identificação de áreas prioritárias para a conservação da biodiversidade por meio da representatividade das unidades de conservação e tipos de vegetação nas ecorregiões da Amazônia brasileira. In: 
CAPOBIANCO JPR. (editor). Biodiversidade na Amazônia brasileira: avaliação e ações prioritárias para a conservação, uso sustentável repartição de benefícios. São Paulo: Instituto Socioambiental, p. 268-286, 2001.

[18] GUEVARA, S.; MEAVE, J.; MORENO-CASASOLA, P.; LABORDE, J. Floristic composition and structure of vegetation under isolated trees in neotropical pastures. Journal of Vegetation Science, 3: 655-664, 1992.

[19] HARVEY, C. A.; HABER, W. A. Remnant trees and the conservation of biodiversity in Costa Rican pastures. Agroforest Systems 44: 37-68, 1999.

[20] HOMMA, A. K. O. Cemitério das castanheiras. Ciência Hoje, v. 34, n. 202, p. 60-63, 2004.

[21] HOMMA, A. K. O.; CARVAlHO, R. A.; FERREIRA, C. A. P.; NASCIMENTO, J. D. N. A destruição de recursos naturais: o caso da castanha-do-pará no sudeste paraense. Belém: EMBRAPA Amazônia Oriental, 74 p. (Documentos 32). 2000.

[22] InSTITUTO DE DESENVOLVIMENTO ECONÔMICO, SOCIAL E AMBIENTAL Do PARÁ (IDESP). Cadeias de comercialização de produtos florestais não madeireiros na Região de Integração Baixo Amazonas, estado do Pará: relatório técnico. Belém, PA: IDESP. 211. 221 p, 2011.

[23] INSTITUTO NACIONAL DE PESQUISAS ESPACIAIS (INPE), 2016. Sistema Integrado de Dados Ambientais. Plataforma de Coleta de Dados. Disponível em:<http........ . Acesso em: 03/09/2016.

[24] INSTITUTO BRASILEIRO DE GEOGRAFIA E ESTATÍSTICA - IBGE. Produção de extração vegetal e da silvicultura. Rio de Janeiro, RJ: Ministério do Planejamento, Orçamento e Gestão, Brasil. Vol. 31, 54 p, 2016.

[25] JANZEN, D. H. Euglossine bees as long-distance pollinators of tropical plants. Science 171: 203-205. https://doi.org/10.1126/science.171.3967.203, 1971.

[26] KAINER, K. A.; WADT, O. H. L.; STAUDHAMMER, C. L. Explaining variation in Brazil nut fruit production. Forest Ecology and Management, Melbourne, n.250, p. 244-255,2007.

[27] KITIMURA, P. C.; MÜLLER, C. H. Castanhais nativos de Marabá-Pa: fatores de depredação e bases para a sua preservação. Belém, EMBRAPA-CPATU. 32 p. (EMBRAPA-CPATU. Documentos 30). 1984.

[28] KNICKER, H. How does fire affect the nature and stability of soil organic nitrogen and carbon? A review. Biogeochemistry, Dordrecht, v. 85, n. 11, p. 91-118, 2007.

[29] KOERSELMAN, W.; MEULEMAN, A. F. M. The vegetation N:P ratio: a new tool to detect the nature of nutrients limitation. Journal of Applied Ecology, London, v. 33, n. 6, p. 1441-1450, 1996.

[30] LANZANOVA, M. E. Atributos físicos do solo em sistemas de culturas sob plantio direto na integração lavoura-pecuária. Santa Maria, Universidade Federal de Santa Maria, 125p. (Dissertação de Mestrado). 2005.

[31] LILLIEFORS, H. W. On the Kolmogorov-Smirnov test for normality with mean and variance unknown. Journal of the American Statistical Association, v. 62 n. 318, p. 399-402, 1967.

[32] LOPES, S. F.; DO VALE, V. S.; SCHIAVINI, E. I. Efeito de queimadas sobre a estrutura e composição da comunidade vegetal lenhosa do cerrado sentido restrito em Caldas Novas, GO. Revista Árvore, Viçosa, v. 33, n. 4, p. 695-704, 2009.

[33] LUIZÃO, F. J. Ciclos de nutrientes na Amazônia: respostas às mudanças ambientais e climáticas. Ciência e Cultura, n. 59, p. 31-35, 2007.

[34] MANNING, A. D.; FISCHER, J.; LINDENMAYER, D. B. Scattered trees are keystone structures - implications for conservation. Biological Conservation 132, 311-321, 2006.

[35] MARTINEZ, L. J.; ZINCK, J. A. Temporal variation of soil compaction and deterioration of soil quality in pasture areas of Colombian Amazonia. ITC J. 3, 252-263, 2004.

[36] MAUÉS, M. M. Reproductive phenology and pollination of the Brazil nut tree (Bertholletia excelsa Humb. \& Bonpl.) in eastern Amazônia. In: KEVAN, P.; IMPERATRIZ FONSECA, V. L. (Eds.). Pollinating bees: the conservation link between agriculture and nature. Brasília: Ministério do Meio Ambiente, p. 245-254, 2002.

[37] MEIRELLES, M. L. Efeito do fogo sobre a umidade do solo em área de campo sujo de cerrado. Ciência e Cultura, São Paulo, v. 42, n. 7, p. 359-360, 1990.

[38] MONTALVO, A. M. \& ACKERMAN, J. D. Limitations to Fruit Production in Ionopsis utricularioides (Orchidaceae). Biotropica. 19, 24-31, 1987.

[39] MORENO, A. DE LIMA, et al, Emissão de CO2 de solos de florestas primária e secundária em regeneração espontânea após corte e queima no sudoeste da Amazônia brasileira. XIX Reunião Brasileira de Manejo e conservação do solo e da água. Lages-SC, 2012.

[40] MORI, S. A.; PRANCE, G, T. Taxonomy, ecology, and economic botany of the Brazil nut (Bertholletia excelsa Humb. \& Bonpl.: Lecythidaceae) Advances in Economic Botany, v.8, p 130-150, 1990 
[41] MORI, S. A.; PRANCE, G. T.; BOLTEN, A. B. Additional notes on the floral biology of tropical Lecythidaceae. Brittonia, v. 30, p. 113-130, 1978.

[42] MÜLLER, M. M. L.; GUIMARÃES, M. F.; DESJARDINS, T.; MARTINS, P. F. S. Degradação de pastagens na Região Amazônica: propriedades físicas do solo e crescimento de raízes. Pesquisa agropecuária brasileira, v. 36, n. 11, p. 1409-1418, 2001.

[43] MÜLLER, C. H.; RODRIGUES, I. A.; MÜLLER, A. A.; MÜLLER, N. R. N. Castanheira-do-Brasil: Resultados de pesquisa. Belém: EMBRAPA, CPATU, 25 p. (Miscelânea, 2). 1980

[44] NELSON, B. W.; ABSY, M. L.; BARBOSA, E. M.; PRANCE, G. T. Observation son flower visitors to Bertholletia excelsa H. \& B. K. and Couratari tenuicarpa A. S. SM (Lecythidaceae). Acta Amazônica (supl.), v. 15, p. 225-234, 1985.

[45] Neill, C. C.; C, Cerri.; J, Melillo.; B, J. Feigl.; P. A. Steudler.; J. F. L, Moraes, and M. C, Piccolo. Stocks and dynamics of soil carbon following deforestation for pasture in Rondonia, p. 9-28. In R. Lal et al. (ed.) Soil processes and the carbon cycle. CRC Press, Boca Raton, FL. Raton, FL. 1997.

[46] NEPSTAD, D.; CARVAlHO, G.; BARROS, A. C.; ALENCAR, A, Capobianco JP, Bishop J. et al. Road paving, fire regime feedbacks, and the future of Amazon forests. Forest Ecology Management, 154: 395-407, 2001.

[47] NEPSTAD, D. C.; MCGRATH, D. G.; SOARES-FILHO, B. Systemic Conservation, REDD, and the Future of the Amazon Basin. Conservation Biology, 25: 1113-1116, 2011.

[48] NOBRE, C. D. O futuro climático da Amazônia. Relatório de Avaliação Científica. Articulación Regional Amazónica, 2014.

[49] NOVAIS, F. R.; SMYTH, T. J. Fósforo em solo e planta em condições tropicais. Viçosa: UFV, 399 p, 1999.

[50] PAIVA, P. M.; GUEDES, M. C.; FUNI, C. Brazil nut conservation through shifting cultivation. Forest Ecology and Management, v. 261, p. 508-514, 2011.

[51] PHILLIPS, O. L.; ARAGÃO, LEOC.; LEWIS, S. L.; FISHER, J. B.; LLOYD, L.; LOPEZ-GONZÁLEZ, G., et al. Drought Sensitivity of the Amazon Rainforest. Science; 323: 1344-1347, 2009.

[52] PHILLIPS, O. L.; HEIJDEN, G. V.; LEWIS, S. L.; LOPEZ-GONZÁLEZ. G.; ARAGÃO, LEOC.; LLOYD, L, et al. Droughtmortality relationships for tropical forests. New Phytologist; 187: 631-646,2010.

[53] RAMOS, A. E.; ROSA, C. M. M. Impacto das queimadas. In: DIAS, B. F. de S. (Coord.).

[54] Alternativas de desenvolvimento dos Cerrados: manejo e conservação dos recursos naturais renováveis. Brasília: Fundação Pró-Natureza, p. 34-38, 1996.

[55] REICHERT, J. M.; SUZUKI, SAEL.; REINERT, J. D. Compactação do solo em sistemas agropecuários e florestais: identificação, efeitos, limites críticos e mitigação, Tópicos Ci. Solo. 5: 49-134, 2007.

[56] RONQUIM, C. C. Conceitos de fertilidade do solo e manejo adequado para as regiões tropicais. Campinas: Embrapa Monitoramento por Satélite. 1a edição. Pag 9, 2010.

[57] SALOMÃO, R. P. Densidade, estrutura e distribuição espacial da castanheira-do-brasil (Bertholletia excelsa H. \& B.) em dois platôs de floresta ombrófila densa na Amazônia setentrional brasileira. Boletim do Museu Paraense Emilio Goeldi Ciências Naturais, v 4 n 1, p. 11-25, 2009.

[58] SCOLES, R.; GRIBEL, R. Population structure of Brazil nut (Bertholletia excelsa, Lecythidaceae) stands in two areas with different occupation histories in the Brazilian Amazon. Human Ecology, v. 39, p. 455-464, 2011.

[59] SCOLES, R.; GRIBEL R. The regeneration of Brazil nut trees in relation to nut harvest intensity in the Trombetas River valley of Northern Amazonia, Brazil. Forest Ecology Management, v. 265, n.1, p. 71-81, 2012.

[60] SCOLES, R.; GRIBEL, R. Human influence on the Regeneration of Brazil nut tree (Bertholletia excelsa, Lecythidaceae) at the Capanã Grande Lake, Manicoré, Amazonas, Brazil. Human Ecology, vol. 43, n. 6, p. 843-854, 2011.

[61] SCOLES, R.; CANTO, M. S.; ALMEIDA, R. G.; VIEIRA, D. P. Sobrevivência e frutificação de Bertholletia excelsa Bonpl. em áreas desmatadas, Oriximiná, Pará. Floresta e Ambiente, 2016, no prelo.

[62] SCOLES, R.; KLEIN, G. N.; GRIBEL, R. Crescimento e sobrevivência de castanheira (Bertholletia excelsa Bonpl.) em diferentes condições ambientais na região do rio Trombetas, Oriximiná, Pará. Boletim do Museu Paraense Emílio Goeldi. Ciências Naturais, V. 6, n.3, p. 273-293, 2011.

[63] SCOLES, R.; KLEIN, G. N.; GRIBEL, R. Crescimento e sobrevivência de castanheira (Bertholletia excelsa Bonpl., Lecythidaceae) plantada em diferentes condições de luminosidade após seis anos de plantio na região do rio Trombetas, Oriximiná, Pará Boletim do Museu Paraense Emílio Goeldi. Ciências Naturais, v. 9, n.2, p. 321-336, 2014

[64] SILVA, V. S. Sistema reprodutivo e diversidade genética de Bertholletia excelsa em diferentes ambientes no Estado do Acre. Dissertação (Mestrado), Universidade Federal do Acre, Rio Branco, 59, 2014. 
[65] SOARES, R. V. Effects of pine plantation prescribed burning on soil chemical properties in the savanna region of Minas Gerais state, Brasil. In: INTERNATIONAL CONFERENÇE ON FOREST FIRE RESEARCH, 1990, Coimbra. Proceedings. Coimbra: Universidade de Coimbra, p. 06 09, 1990.

[66] SOUZA, Z. M. et al. Variabilidade espacial de atributos físicos de um Latossolo Vermelho sob cultivo de canade-açúcar. Revista Brasileira de Engenharia Agrícola e Ambiental, Campina Grande, v. 8, n. 1, p. 51-58, 2004.

[67] SUJII, P. S.; MARTINS, K.; WADT, L. H. O.; AZEVEDO, V. C. R, et al. Genetic structure of Bertholletia excelsa populations from the Amazon at different spatial scales. Conserv. Genet. 116: 955-964. https://doi.org/10.1007/s10592-015-0714-4, 2015.

[68] SUTHERLAND, S. Why hermaphroditic plants produce many more flowers than fruits: experimental tests with Agave mckelveyana. Evolution, 41, 750-759, 1987.

[69] ULERY, A. L.; GRAHAM, R. C.; AMRHEIN,C. Wood-ash composition and soil pH following intense burning. Soil Science, Madison, v. 156, n. 5, p. 358-364, 1993.

[70] VAISSIÈRE, B.; FREITAS, B.; GEMIL-HERREN, B. Protocol to detect and assess pollination deficits in crops. Roma: FAO. 26 p, 2009.

[71] WADT, L. H. O.; KAINER, K. A.; GOMES-SILVA, D. A. P. Population structure and nut yield of a Bertholletia excelsa stand in Southwestern Amazonia. Forest Ecology and Management, v.211, p.371-384, 2005.

[72] WADT, L. H.O.; KAINER, K. A.; STAUDHAMMER, C AND SERRANO, R. Sustainable forest use in Brazilian extractive reserves: Natural regeneration of Brazil nut in exploited populations. Biol. Conserv, 141: 332-346. https://doi.org/10.1016/j. 2008.

[73] WADT, L. H. O.; SILVA, V. S. Sistema Reprodutivo e Diversidade Genética de Bertholletia excelsa em diferentes ambientes no Estado do Acre. EMBRAPA, 2016. 


\title{
Capítulo 22
}

\section{Diagnóstico do nível de pressão sonora no núcleo urbano do município de Capanema - PA}

\author{
Mateus Lopes Moreira \\ Thais Gleice Martins Braga \\ Eduarda Randel Guimarães Souza \\ Ricardo Cunha de Oliveira \\ Evellem Vitória de Souza Freitas \\ Igor de Souza Gomide
}

Resumo: 0 desenvolvimento dos centros urbanos através do processo de globalização, traz consigo problemas ao meio ambiente e consequentemente a vida da população, muito devido as cidades não estarem preparadas para tal avanço. Tais atividades influenciam nos níveis de pressão sonora e que afetam diretamente a qualidade de vida da população. Atualmente, o ruído urbano é um deles, que pouco se fala sobre tal problemática se comparado a outros tipos de impacto. Este trabalho objetiva analisar e identificar in loco quais são os fatores provenientes das atividades que influenciam o nível de pressão sonora no núcleo urbano do município de Capanema/PA e modelar a propagação de ruído a fim de visualizar melhor quais os locais na área de estudo que sofrem com a influência do ruído e contrapor com os parâmetros estabelecidos pela NBR 10.151 e então a partir dos resultados adquiridos propor medidas de controle aos órgãos competentes. A metodologia utilizada foi pautada nos parâmetros de medição de ruído para ambiente externos estabelecidos na NBR 10.151, sendo realizada revisão bibliográfica, sobre métodos de interpolação geoestatística, mais adequado para a espacialização acústica. Sendo assim, selecionou o mapa acústico que melhor representou os níveis de pressão sonora, levando em consideração as análises in loco, bem como os possíveis erros de interpolação de cada método, obtendo assim, os resultados da pesquisa, constatando que o núcleo urbano apresenta índices de LAeq superiores ao que é permitido. Ao final deste trabalho, com base nos produtos, identificou ampla deficiência no sistema de gestão municipal voltado para aplicação da legislação de poluição sonora. Por fim, visando minimizar os impactos constatados pelo presente, se propôs medidas mitigatórias como considerações finais pertinentes, oriundas do estudo.

Palavras chave: Modelagem de poluição sonora, controle ambiental, análises ambientais, monitoramento na Amazônia. 


\section{INTRODUÇ̃̃OO}

Atualmente com o processo de urbanização acelerado e o aumento demográfico das cidades, há o crescimento desordenado, que propicia o aparecimento de fontes geradoras de ruído que afetam a população. Esse agente em excesso desencadeia a poluição sonora que afeta diretamente a qualidade de vida da população. Segundo a Organização Mundial da Saúde (OMS) afirma que a poluição sonora é a fonte que impacta à população ficando atrás somente da poluição do ar. Tal impacto afeta a qualidade de vida da sociedade causando problemas no sistema auditivo e reações psicofisiológicas (BARROS, 2000; GUEDES, 2005; WHO, 2011).

0 processo de industrialização impulsionou o crescimento das cidades, fazendo com que as pessoas buscassem se concentrar na zona urbana, devido a necessidade de espaço para se instalar. Em detrimento disso, o número de veículos motorizados cresceu causando um agravamento na poluição sonora, aumentando assim, a quantidade de reclamações da população em relação ao ruído gerado nas cidades. Levantamentos foram realizados em vários locais, onde se identificou que o ruído de tráfego é o maior contribuinte, para os níveis sonoros medidos, e a maior causa de incômodo em áreas urbanas. (GERGES, 2000; ZANNIN et al, 2005; DE MELO, 2010; AMORIM, 2017; PRESUMIDO et al, 2018; CABRAL, 2013).

Diante dessa problemática, os órgãos governamentais e entidades regulamentadoras estabelecem diretrizes sobre o meio ambiente e as questões quanto aos níveis de pressão sonora, para que se tenha um ambiente equilibrado e que promova a qualidade de vida. Como exemplo temos o âmbito estadual, no qual a constituição de 1989 institui em seu Art.17ํque é competência dos estados e municípios junto à união proteger o meio ambiente e combater a poluição em qualquer de suas formas (PARÁ, 1989).

Além disso, Lei Estadual no 5887 de 09 de maio de 1995 intitulada de Política Estadual de Meio Ambiente define em seu artigo $2 \mathrm{o}$ incisos II que "o Estado e a coletividade têm o dever de proteger e defender o meio ambiente, conservando-o para a atual e futuras gerações, com vistas ao desenvolvimento sócioeconômico" (PARÁ, 1995).

No município de Capanema/PA, pertencente à Mesorregião do Nordeste Paraense e a Microrregião Bragantina, que se encontra em crescente desenvolvimento, nos últimos 9 anos, de 2010 a 2018, o município teve um crescimento demográfico de $7,82 \% 63.639$ para 68.616 habitantes, IDHM de 0,655, $\mathrm{R} \$ 571.598,00$ e PIB per capita $\mathrm{R} \$ 14.740,17$ segundo (IBGE, 2018).

Nessa perspectiva, o estudo visa diagnosticar o nível de pressão sonora por meio de medições in loco, no município de Capanema, Pará.

\section{METODOLOGIA}

\section{1 ÁREA DE ESTUDO}

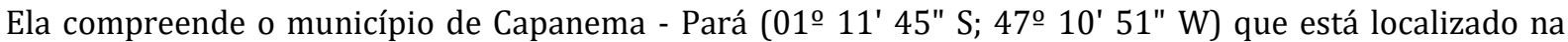
mesorregião do nordeste paraense (Mapa 1), microrregião leste paraense zona bragantina, distante 165 $\mathrm{km}$ da capital do estado, Belém.

O clima da região é do tipo amazônico tropical chuvoso segundo a classificação de Köppen (1931), com temperatura média anuais de $25^{\circ} \mathrm{C}$ a $26^{\circ} \mathrm{C}$ e pluviosidade de 2200 a $3000 \mathrm{~mm} /$ ano. Devido à localização do município em questão estar sob a linha do equador e apresentar consequentemente temperaturas elevadas no decorrer do período chuvoso e menos chuvoso e ser comprovado que em temperaturas acima de $20^{\circ} \mathrm{C}$ há maior índices de propagação de ruídos, entende-se que nesta área de estudo, haverá maior viabilidade de propagação até mesmo pelas características climatológicas (CABRAL, 2012; MOURA, 2016).

Os índices de vegetação presentes na região nordeste do Estado do Pará, com vegetação primitiva de floresta densa dos baixos platôs Pará/Maranhão que foi quase que totalmente substituída pela floresta secundária (ARCHELA, 2008).

No entanto, não foi identificado na área de estudo elevados índices quantitativos de vegetação de porte médio e alto, visto que tal informação, quanto a características florísticas é importante, porque de acordo com Gerges (1992), a vegetação contribui para uma atenuação de $2 \mathrm{dG}$ em $1 \mathrm{kHz}$, ou seja, é necessária uma área de árvores densas à $10 \mathrm{~m}$ de distância da fonte e com uma largura de $20 \mathrm{~m}$. 


\subsection{COLETA DE DADOS}

Portanto o estudo pautado em análises descritivas e de caráter exploratório, traçado em uma visão holística e sistêmica, oriundo de dados técnicos, científicos, bibliográficos, informativos, jurídicos, noticiários, publicações do diário oficial do estado do Pará, bem como a união. Além disso, a presente pesquisa pautou-se em análises dentro dos limites de influência direta, afetada e indireta dos atores de geração de ruídos e pressão sonora selecionados, levando em consideração os critérios de onde estão localizados, como, centros comerciais (LOJAS, SUPERMERCADOS, VEÍCULOS DE PROPAGANDA), feiras (Tv. Duque de Caxias e 14 de março), bairro residencial (São Pio X), e rodovias (Avenida João Paulo II (PA 124), BR 308). Para que se tivesse uma representatividade das causas dos níveis de pressão sonora e dos locais no núcleo urbano do município (Figura 1).

A metodologia utilizada para a medição do nível de pressão sonora sendo devidamente realizada de acordo com os parâmetros estabelecidos na ABNT NBR 10151/2000 (Acústica - Avaliação do ruído em áreas habitadas, visando o conforto da comunidade - Procedimento).

\subsection{EQUIPAMENTO DE MEDIÇÃO}

Seguindo as especificações da norma, utilizando para medição de ruído o Medidor de Nível Sonoro, vulgarmente chamado de "Decibelímetro". De modelo DEC-490, fabricado pela INTRUTHERM seguindo os critérios da IEC 61672-1 CLASS 2, calibrado pelo seu próprio laboratório do fabricante, de acordo o certificado de calibração № 97865/19 no dia 03/04/2019.

Para posicionar o aparelho em uma altura para se realizar a medição, foi necessário utilizar um tripé de aproximadamente 1,20m conforme definido na ABNT NBR 10151/2000.

\subsubsection{CONFIGURAÇÃO DO APARELHO}

Determinou a ponderação do nível de pressão sonora equivalente (LAeq), configurado o medidor no intervalo de 30 a 130 decibéis, no modo Fast para que se forneça o valor de pico do nível de pressão sonora a cada 1 segundo, levando em consideração a curva de ponderação "A" $\mathrm{Db}(\mathrm{A})$ e assim ter uma abrangência melhor do LAeq presente no local.

De acordo Mendonça, (2012) para medições com tempo de amostragem de 5 e 15 minutos a diferença estatística não é significativa. Como a norma não define um tempo de medição exato, adotando um tempo de medição de 10 minutos para que se pudesse ter uma representatividade maior de cada ponto de medição.

\subsection{TABULAÇÃO DOS DADOS}

Para cada ponto de medição as informações foram anotadas em um formulário de medição com o intuito de manter a organização na hora de tabulação dos dados.

Após a coleta de todos os pontos, os dados contidos no data logger do decibelímetro foram extraídos do aparelho a partir do programa Sound Level Meter e trabalhados em uma planilha eletrônica para que se pudesse obter os níveis equivalentes de pressão sonora de cada, através de uma fórmula logarítmica Equação 2 definida na ABNT NBR 10.151/2000.

A partir da tabulação das leituras realizadas foram gerados gráficos para todos os pontos de medição

$$
\text { LAeq }=10 \log \frac{1}{n} \sum_{-1}^{n} 10 \frac{L i}{10}
$$

\subsection{INTERPOLAÇÃO}

Na fase de validação dos métodos, bem como no processo de modelagem do cenário atual de propagação de ruídos, abordou três métodos para serem utilizados, pois são métodos que permitem a transformação de um conjunto de valores pontuais, assumidos com pontos de amostra de uma grandeza de variação contínua, numa superfície de valores da grandeza em análise. 
Diante disso, a partir de uma revisão de literatura, se escolheu os métodos empregados, este estudo englobou os principais modelos de interpoladores utilizados na análise de dados espaciais, como: Krigagem, inverso ponderado da distância (IDW); e Spline, (VENTURA, 2008; DOS SANTOS, 2013).

\subsubsection{KRIGAGEM ORDINÁRIA}

O primeiro método utilizado foi da Krigagem ordinária pelo semivariograma gaussiano, e este não apresentou-se como um método relevante para este estudo, devido ser recomendado para estudos que detém de pontos de controle amplamente distribuídos o que não é o caso deste estudo que distintamente apresenta pontos de coletas centralizados, em uma área pontual (Núcleo urbano da cidade de Capanema) e não amplamente distribuídos, logo este método é recomendado para estudo de propagação de ruídos e poluição sonora em grandes cidades ou para estudos que irão abranger grandes extensões territoriais, tendo pontos de controle amplamente distribuídos.

\subsubsection{IDW (ÍNDICE DA DISTÂNCIA MAIS PRÓXIMA)}

Sucessivamente adotou um segundo método, sendo este o IDW (índice da distância mais próxima), que não foi considerado como método validado, devido ser melhor usado para áreas que apresentam baixos índices de rugosidade, como por exemplo sem a presença de construção civil, prédios, barreiras, rugosidades significativas (relevo, pavimentação,) sendo portanto mais recomendado para áreas de estudo livre sem relevos e barreiras significativas, não sendo as características da área de estudo deste trabalho.

\subsubsection{SPLINE}

Por fim, utilizou-se o terceiro teste, denominado de Curva Mínima - Spline. Esta metodologia, permite verificar a alteração na rugosidade do terreno e mantém os valores fiéis aos estabelecidos, tornando a projeção do ruído no núcleo urbano mais representativa e similar ao analisado em campo, pelo fato de que no cálculo do modelo geoestatístico possibilitar que seja empregado índices a modo de assemelhar a influência das barreiras acústicas em relação aos níveis de ruído encontrado. Logo, a metodologia de interpolação da Spline, apresentou-se mais adequada para se trabalhar e moldar o mapa acústico do núcleo urbano do município de Capanema/PA, pois apresenta capacidade de análise conforme as especificidades do terreno e da área em estudo, levando em consideração as barreiras, declividades, características específicas do centro urbano do município, permitindo assim uma análise de pontos de controle pontuais e/ou centralizados.

A metodologia Spline consiste em um método de interpolação muito aceito e utilizado atualmente. Distinto de outros métodos de interpolações polinomiais, o Spline não utiliza apenas um polinômio de grande ordem para interpolação de todo o conjunto de dados, mas sim divide a série de dados em subconjuntos e utiliza polinômios de pequenas ordens para cada subconjunto. (JAKOB, 2016. FARIAS et al, 2017).

Visto que amplos testes e validações foram realizados, visando obter o melhor método, com a maior veracidade dos dados possíveis, bem como o menor índice de erros e desvio padrão, adotou-se a interpolação matemática através do sistema de informações geográficas, fazendo uso para este processo de modelagem do software Arcgis 10.5, para a aplicação de técnicas de interpolação espacial de dados que está se tornando cada vez mais difundido no contexto das análises geográficas.

A partir do processo Tension, o qual analisa dados adquiridos em superfície menos suave, com valores mais condicionados pelos valores da amostra, com pesos elevados sendo destinado a superfície com maior rugosidade, ou seja, menos suave. É empregado pesos dentro de uma escala de $(0,1,5$ e 10). E de acordo com Schenatto, (2014) essa metodologia é usada cuja variação dos dados seja moderada, como precipitação, altimetria e poluentes.

\subsection{ANÁLISES DOS DADOS}

A abordagem deste estudo técnico científico subsidiou-se em análises quantitativas, visto que o presente estudo teve um total de 47 pontos de medição, coletados nas vias que constituem o núcleo urbano do município de Capanema/PA, bem como análises qualitativas através do uso de equipamentos devidamente calibrados e adequados para as análises aqui expostas, tais como: o equipamento de medição dos níveis de pressão sonora, ou seja, o decibelímetro, bem como o GPS de navegação para aquisição das 
coordenadas geográficas dos pontos de controle, softwares de processamento digital de dados como o Arcgis 10.5, planilha eletrônica e câmera fotográfica.

A avaliação do nível de pressão sonora equivalente $\left(L_{A e q}\right)$ sendo realizada no núcleo urbano da cidade de Capanema-PA, período diurno entre as 08:00 e 12:00 entre 15/04/2019 e 24/04/2019 em pontos de medição nas principais vias de maior circulação da cidade, e estão localizadas nos bairros São Pio X, Garrafão, Dom João VI e Centro. Dentre as vias estão: a Avenida João Paulo II, BR-308, Travessa Coronel Leandro Pinheiro, Rua Duque de Caxias, Rua Sebastião de Freitas, Avenida Barão de Capanema, Rua Dom Pedro II, Travessa Quatorze de Março. Esses bairros foram caracterizados como área residencial, industrial, comercial e mista.

Para uma acuracidade maior no diagnóstico do nível de pressão sonora no município, foram selecionados os pontos de medição entre a interseção das principais vias, com o intuito de aumentar a classe amostral e ter um resultado mais representativo.

\section{RESULTADOS E DISCUSSÃO}

A partir da medição e observação in loco dos 47 pontos de medição, foi possível obter dados que demonstrasse como está o comportamento dos níveis de pressão sonora no núcleo urbano do município de Capanema e assim determinar através do mapa acústico quais são os pontos de maior intensidade de ruído e identificar os atores responsáveis pela sua geração.

Todos os pontos de medição tiveram os seus níveis de critério de avaliação - NCA (Tabela 1) determinados levando em consideração ao observado em campo e comparando com o que está estabelecido na ABNT NBR 10.151/2000 e junto à Lei municipal no 6.350/2014.

Os resultados obtidos dos níveis de pressão sonora equivalente na maioria dos pontos estudados apresentaram valores elevados (Tabela 2), ultrapassando os limites estipulados pelas normas em vigor. Os pontos fora do padrão representam cerca de $97 \%$ do total de pontos estudados, ou seja, 46 pontos estão em desacordo com a norma. Por outro lado, apenas 1 ou $3 \%$ dos pontos estão de acordo com a norma. É importante salientar que este ponto foi caracterizado como uma área predominantemente industrial, onde o limite é $70 \mathrm{~dB}(\mathrm{~A})$ por estar nas proximidades de uma fábrica. Já os demais pontos foram classificados como:

- Área estritamente residencial ou de hospitais ou de escolas;

- Área mista predominantemente residencial;

- Área mista, com vocação comercial e administrativa.

Os dados obtidos foram tabulados e gerados gráficos (Gráfico 1) para analisar e ter uma melhor visualização do comportamento dos níveis de ruído em relação com a norma.

Foram gerados mapas acústicos a partir do LAeq de todos os pontos de medição, com intuito de realizar mapeamento e a modelagem acústica. De acordo com SANTOS, (2004) os mapas são um salto importantíssimo para se abordar o problema da poluição sonora, pois auxilia na análise do ruído, e concede subsídio para o planejamento e ordenamento do território.

Sobre uma área de influência de $500 \mathrm{~m}$ de cada ponto, devido ao som se propagar em várias direções devido os fenômenos que acontecem na propagação de ruído como reflexão, absorção, transmissão, difusão, difração e refração, e como se observou as fontes de emissão vão para todos os lados.

Então, como resultado primário da modelagem para encontrar o método de interpolação mais adequado foi gerado um mapa proveniente da krigagem ordinária (Mapa 2) utilizando o modelo gaussiano, que é indicado para modelar fenômenos extremamente contínuos.

Podemos verificar que a espacialização do ruído não se caracterizou representativa com o visualizado em campo, devido à disposição espacial dos pontos ser irregular o que ocasionou o efeito pepita. Nesse caso, alguns autores atribuem essa descontinuidade aos erros de medição ou da variabilidade pequena da escala não captada pela amostragem (CAMARGO,1997; DOS SANTOS, 2014).

Em busca de alcançar um modelo próximo do ideal, quanto a representação acústica dos níveis de pressão sonora, elaborou-se o mapa de distribuição da pressão acústica (Mapa 3), por meio do método de interpolação geoestatística, neste caso, representado pelo Índice da Distância mais próxima - IDW. 
A interpolação por intermédio deste método demonstrou boa competência e semelhança com o avaliado em campo. A vantagem deste método de ponderação é a fidelidade aos dados inseridos na coluna "z", consistindo em aproximações precisas das derivações, e boa estabilidade na presença de erros de aproximação. Embora não seja um modelo exato, mas em comparação com os demais métodos considerados interpoladores exatos, constatou-se que eram semelhantes aos demais modelos.

É preciso considerar que um dos problemas encontrado neste modelo geoestatístico utilizado neste estudo, é a não avaliação da predição de erros, que pode produzir um efeito "Alvo" ao redor da localização do dado, ou seja, pequenas áreas que se diferenciam da suavização geral da variável Jakob, (2016). Além do mais, este método está levando em consideração apenas uma superfície plana sem influência de barreira acústica, como casas, prédios e o relevo.

Fazendo com que sua representatividade fosse descartada apesar da boa semelhança. Porque de acordo com a análise in loco da área do núcleo urbano do município, não se trata de um local sem qualquer tipo de barreira, então, esta metodologia não é indicada para a projeção dos valores encontrados, pois o modelo IDW não leva em consideração os fatores de rugosidade do terreno.

Por conseguinte, a modelagem dos dados foi executada através do método geoestatístico da Curva Mínima - Spline (Mapa 4) que permite ajustar o modelo empregando rugosidade na superfície.

A partir da comparação dos mapas produzidos como produtos da modelagem, a metodologia de interpolação da Curva Mínima - Spline apresentou-se mais adequada para demonstrar o comportamento acústico no núcleo urbano do município de Capanema/PA devido estar de acordo com o observado em campo.

Vale ressaltar que todos os modelos apresentaram uma espacialização dos níveis de pressão sonora acima do limite estabelecido pela ABNT, NBR 10.151/2000, devido esses métodos de interpolação se manterem fiéis aos dados inseridos

Diante da análise in loco o ruído de tráfego é o maior causador da poluição sonora, tornando-se bastante flutuante no tempo, além de apresentar variações durante os diferentes períodos do dia. Na prática, as medições somente fazem a amostragem de uma parte da exposição, logo, o critério de amostragem apresenta certa incerteza na estimativa da exposição total do ruído. A precisão das medições e os detalhes dos procedimentos de medição devem estar de acordo com o tipo de ruído e com outros detalhes da exposição ao ruído.

Mapa 5 - Produto dos diferentes métodos de interpolação.

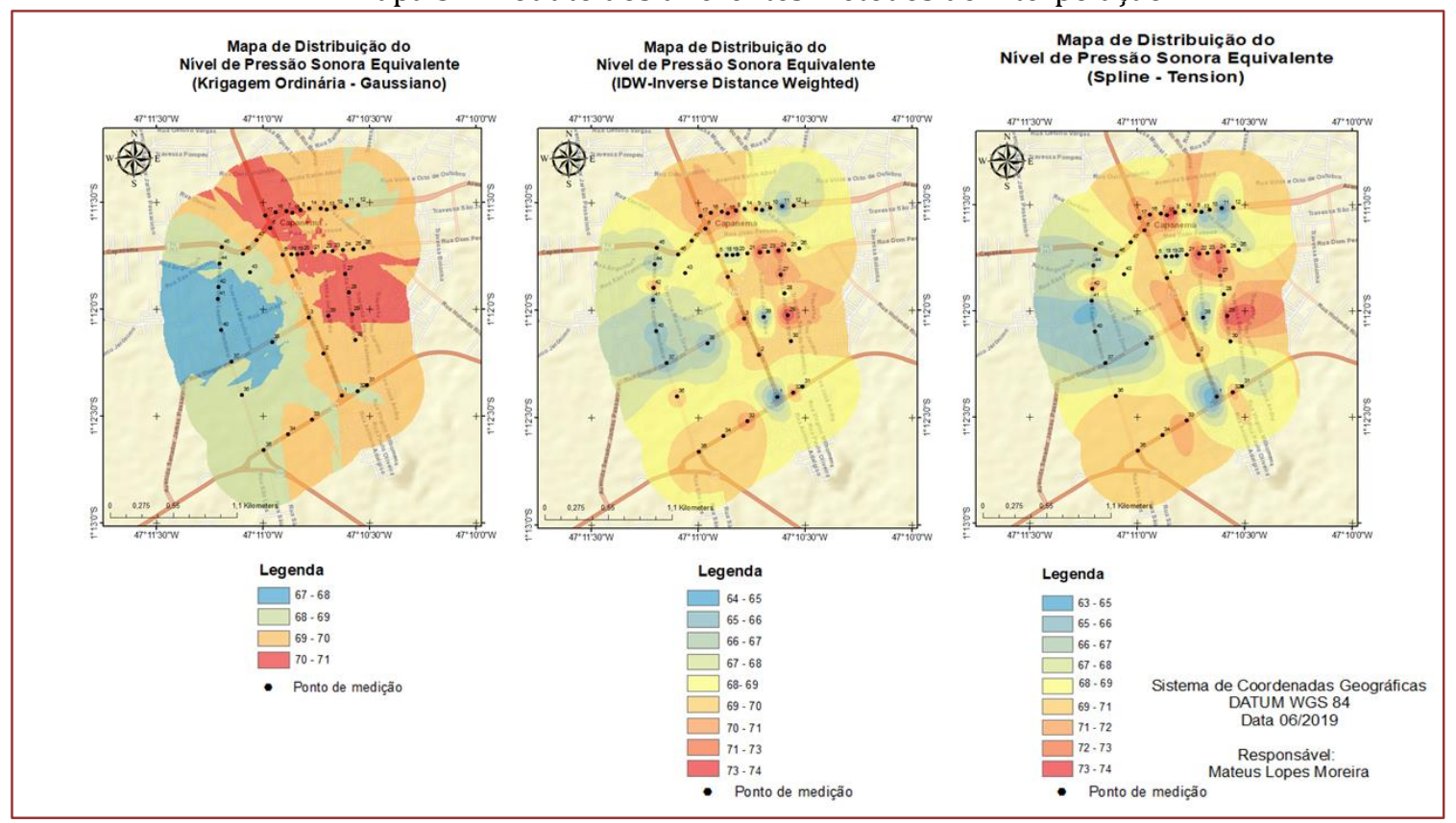


Os erros associados ao ruído de tráfego podem ser bastante diferentes dos associados a outros ruídos, que apresentem diferentes comportamentos em relação à sua variação temporal. Vaskor et al. (1979) mostram que pode ser esperado, por exemplo, um erro médio de 2 a $3 \mathrm{~dB}(\mathrm{~A})$ para o $L_{A e q}$, no período diurno.

Analisando o mapa de Distribuição acústica a área em azul foi classificada como área mista, predominantemente residencial que engloba os pontos $(37 ; 38 ; 40 ; 41 ; 45)$, onde os valores de referência não podem ultrapassar $55 \mathrm{~dB}(\mathrm{~A})$. No entanto, o índice desta área está entre $63 \mathrm{~dB}(\mathrm{~A})$ e $65 \mathrm{~dB}(\mathrm{~A})$, ou seja, mesmo com o erro médio, esses valores estão acima do permitido.

De acordo com a análise do levantamento das anotações durante o processo de medição nessa área, foi possível identificar que o fluxo de veículos é moderado, e toda essa região tem circulação de veículos como carros, motos e caminhões. Um fato de extrema relevância para o levantamento ocorreu na Travessa Leandro Pinheiro, localizada no mapa na região em azul, onde observou-se o tráfego de motocicletas com o escapamento não homologado pelo CONTRAN, produzindo ruídos elevados nessa região em sua passagem.

Os pontos $(43 ; 47)$ visualizados na representação representam bem o comportamento do $L_{A e q}$ em relação ao observado em campo. Esses pontos estão na zona de transição, justificando que quanto mais próximo do centro comercial maior serão os níveis de ruído devido ao tráfego de pessoas e veículos.

No centro comercial (Figura 2), observou-se que os índices estabelecidos pela legislação foram ultrapassados, gerando assim impactos ao sistema biótico. Esta zona é influenciada por diversos fatores de geração de ruído como, tráfego de veículos leves e pesados, assim como nos pontos citados anteriormente. Retirando da análise o ruído de tráfego, a partir da análise in loco essa zona sofre com a indecência do ruído proveniente de veículos de propaganda comercial fixo e volante conforme.

Foi evidenciado a ação dos veículos de propaganda sobre a emissão de ruído, onde percebeu-se que o volume está elevado muita das vezes, causando assim perturbação nas pessoas presentes nesta região. Mais na frente ponto 9 constatou a presença de duas caixas de som alocadas em dois postes em um mesmo cruzamento conforme.

Portanto, retirando o ruído de tráfego da análise, pelo fato de se um ator está presente no cotidiano e ser evidente a sua influência sobre a poluição sonora nesta zona, identificou que na região comercial do núcleo urbano do município de Capanema/PA, a poluição sonora advém principalmente de veículo de propaganda.

A partir da avaliação do mapa de distribuição acústica e do observado em campo, os pontos $(11 ; 12)$ revelam que com o distanciando do centro comercial os níveis de pressão sonora começam a decair, mesmo assim segundo o mapa acústico os valores ainda acima do permitido de $60 \mathrm{~dB}(\mathrm{~A})$.

Os pontos (22; 24), mostrados na Figura 3, revelam um elevado índice de poluição sonora, devido sua localização ser a convergência de vias de elevado fluxo de veículos. 0 ponto 22 por dá acesso ao centro comercial pela Travessa Djalma Dutra e o ponto 24 por estar localizado na saída da Travessa 14 de Março ligando-se a Travessa Dom Pedro II importante via para chegar a diversos lugares na cidade, então, fez com que nesse ponto os valores limites forem ultrapassados conforme a visualização do mapa de distribuição acústica.

Em virtude a convergência da PA-124 e da BR-308 no ponto 1 e essa via ir em direção a BR-316 para que se saia do núcleo urbano do município de Capanema/PA no trevo localizado próximo ao ponto 35 a localização dos pontos $(1 ; 31 ; 32 ; 33 ; 34 ; 35 ; 36)$ nessa região foi classificado como uma área predominantemente industrial, por ser uma área perto de uma indústria de fabricação de cimento a CIBRASA e outras demais indústrias. E diante da localização das vias perto desses empreendimentos e de rodovias federais e estaduais, esses determinados pontos sofrem influência do ruído de tráfego como principal fonte geradora.

Analisando os resultados desses pontos, de acordo com a norma e contraponto com o erro estabelecido do $L_{\text {Aeq }}$ para o período diurno de 2 a $3 \mathrm{~dB}(\mathrm{~A})$ segundo Vaskor et al. (1979), sendo possível concluir que está região em específico do núcleo urbano do município de Capanema está de acordo com os limites estabelecidos pela norma Brasileira.

Especificamente o ponto 1 (Figura 4) nessa região sofreu menor influência dos atores de geração de ruído devido a sua localização como demonstrado na figura abaixo. 
Como dito por Fiorillo, (2012) 80\% dos ruídos são provenientes do ruído de tráfego, sendo possível verificar isso no ponto 1, à localização que se dá em um trevo que liga a BR-308 à Avenida João Paulo II ou PA-124 perímetro urbano, os veículos trafegavam em baixa velocidade devido à presença do trevo que exige que os motoristas diminuam a velocidade para adentrar nas vias, o que resulta em um nível de pressão sonora mais baixo. Devido a velocidade que possam provocar baixos índices de ruído na geração de ruído. Na Gráfico 2 podemos observar que a oscilação é pouca, devido justamente os veículos trafegarem em baixa velocidade.

Os picos representados no gráfico se dão por causa de veículos de grande porte que passavam pelo local devido está localizada próxima a uma rodovia Federal e Estadual.

Diante dos resultados, identificou-se pontos que devem ter atenção $(4 ; 26 ; 29)$ em virtude destes locais estarem perto de hospitais, escolas e creches. Onde de acordo com o que é visualizado na norma, esses pontos têm índices baixos. 0 ponto 4 se encontra perto da EEFM Padre Salles e do Hospital Saúde Center hospital, o ponto 26 se localiza próximo a Escola de Ensino Infantil e Fundamental Emília, o ponto 29 é localizado nas proximidades da Creche Municipal Almerinda Martins da Costa.

O ponto de medição 4 (Figura 6) está localizado na Avenida João Paulo II que é parte integrante da PA 124 no perímetro urbano do município de Capanema/PA, a partir do monitoramento, por meio da medição constatou que o determinado ponto sofre com os níveis de ruído elevados, devido sua localização ser em uma rodovia estadual no perímetro urbano do município, onde ocorre o tráfego de veículos de todos os tipos. Conclui-se tal influência a partir da análise dos pontos adjacentes que o antecedem.

Diante da análise do Gráfico 3 é possível verificar que o nível de ruído desta área está acima do permitido em todo o tempo de medição, resultando assim, em cerca de $20 \mathrm{~dB}$ (A) de diferença do NCA estabelecido de $50 \mathrm{~dB}(\mathrm{~A})$ para o que foi encontrado 70,50 dB (A).

A análise do Gráfico 4 que representa o ponto 26 localizado na Travessa Dom Pedro II próximo à praça Lions, demonstra que os níveis de pressão sonora estão acima do permitido, pode-se observar in loco a influência do ruído de tráfego por meio de veículos de pequeno porte como carros e motos, sendo pouca a influência de veículos maiores em virtude do ponto de medição está localizada mais próximo ao centro comercial do município de Capanema/PA

Diante da análise de todos os pontos medidos, que antecederam o ponto 26 (Figura 7), pode-se observar que quanto mais próximo do centro comercial do município, maior a influência de atores, como veículos de propaganda. Esse apresentou de maior frequência em quase todos os pontos antecessores.

Tal influência foi comprovada na impactando assim no nível de pressão sonora equivalente, onde o permitido neste ponto diante da norma é de $50 \mathrm{Db}(\mathrm{A})$. No entanto, de acordo com o resultado do $L_{A e q}$ os valores obtidos estiveram acima de 60,28 dB (A), ou seja, muito além do permitido.

0 ponto 29 (Figura 8), localizado entre a Travessa 14 de março e Travessa Duque de Caxias, esse determinado ponto concentra uma espécie de feira livre. Nessa região se encontram supermercados, açougues, feirantes, essa concentração de estabelecimento neste local, atrai uma grande quantidade de circulação de pessoas.

Gráfico 5 - Representação gráfica do NPS no ponto 29.

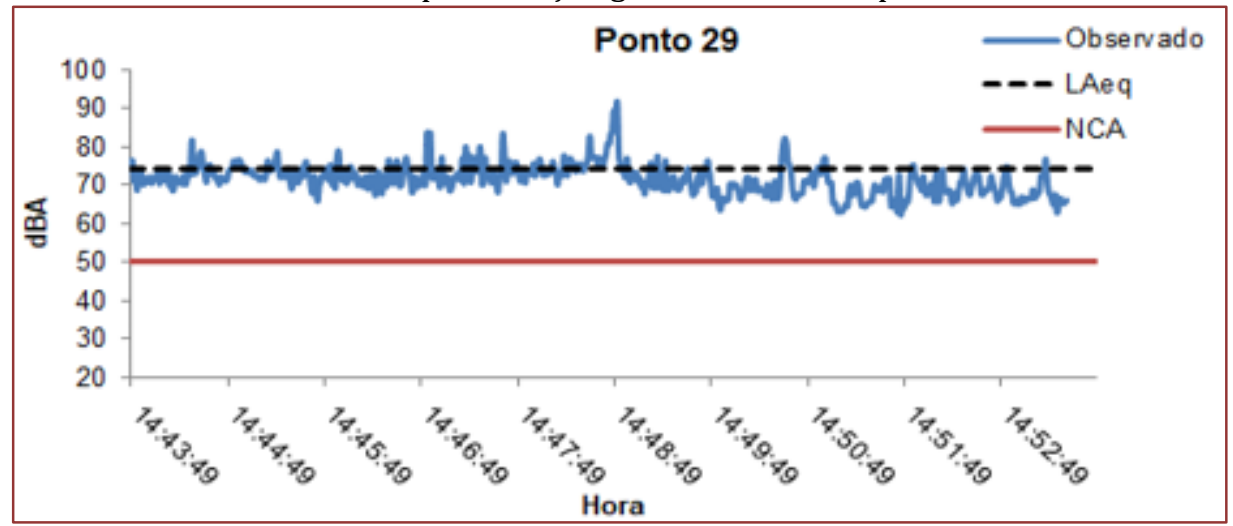

Fonte: Autor, (2019). 
De acordo com o que foi levantado in loco, isso se deve a presença de caixas de som em postes vinculadas a uma rádio do município, divulgação comercial de um estabelecimento comercial através de uma caixa de só em frente ao empreendimento, veículos de propaganda volante e por ser um ponto de interseção de duas vias principais do núcleo urbano a influência proveniente do ruído de tráfego.

\section{ANÁLISE DO RUÍDO NO NÚCLEO URBANO}

A região do núcleo urbano do município de Capanema sendo caracterizada em 3 tipos de áreas, área mista predominantemente residencial, área mista com vocação comercial e administrativa e área predominantemente industrial tendo como base a ABNT NBR 10151/2000 e a Lei Municipal no 6350/2014. Logo, identificou as principais fontes de geração de ruído de cada área e do núcleo urbano como um todo.

A partir do conteúdo dos dados obtidos nesse estudo, contatando grande impacto da poluição sonora no núcleo urbano do município de Capanema/PA, onde o ruído de tráfego é o maior causador de ruído em todos os pontos avaliados devido a circulação de veículos emitindo níveis variados de ruído em virtude da velocidade, estilo de pilotagem do motorista e a pavimentação da via.

Nos cruzamentos das vias onde se tem a presença de semáforos especificamente nos pontos $(3 ; 4 ; 6 ; 8 ; 9$; 29) percebeu-se que a concentração de veículos nesse determinado ponto que propiciou o aumento do nível de ruído devido à rotação do motor, escapamento originais e irregulares, e a ação de aceleração e desaceleração dos veículos.

Na região do centro comercial foi verificado um elevado nível de ruído durante o levantamento, que por ser uma cidade onde a economia é proveniente principalmente do comércio, a zona comercial é bastante movimentada com intenso tráfego de carros, ônibus, caminhão, moto, os veículos propaganda dos mais variados tipos que são os principais causadores de ruído.

Vale ressaltar que $97 \%$ dos pontos analisados, os índices encontrados estavam acima do permitido. Mas aplicando o erro médio estabelecido por Vaskor et al. (1979) para ruídos diurnos de 3 dB (A) na área predominantemente industrial esse valor cai para $95 \%$ dos pontos acima permitido.

Conforme evidenciado, o principal agente causador da poluição sonora no núcleo urbano do município de Capanema/PA é o tráfego de veículos como carro, motos, caminhões, ônibus, estratificando esses atores, o causador de maior relevância são as motos, com escapamento irregular não homologados pelo Instituto Nacional de Metrologia Qualidade e Tecnologia - INMETRO.

Na qual segundo o Artigo no 230 do Código de Trânsito Brasileiro Lei no 9.503, de 23 de setembro de 1997 o equipamento poluidor deve ser apreendido pelas autoridades competentes (BRASIL, 1997). Mas no município de Capanema/PA consta-se que há deficiência no sistema de fiscalização no trânsito por parte do Departamento Municipal de Trânsito - DEMUTRAN em relação este determinado item mesmo sendo declarado ilegal pelo Código de Trânsito Brasileiro.

Os veículos de propaganda como caixas de som nos postes, carro som e bicicleta som, são geradores de ruído no centro comercial e que esses atores não sofrem fiscalização por parte dos órgãos competentes e a maioria dos veículos de propaganda não são licenciados para a atividade. Em diversos pontos de medição foi constatado a presença de veículos de propaganda e foi perceptível os mais variados níveis de volume.

Levando em consideração a Lei Municipal 6.350/2014, no Art.7º parágrafo único, onde diz que é proibido a circulação de veículos de publicidade fixo ou volante a menos de $150 \mathrm{~m}$ (cento e cinquenta metros) de escolas (CAPANEMA, 2014). Tal item presente na lei é totalmente ignorado, conforme a Figura 9 onde é possível identificar um carro som perto passando na frente de uma escola com o áudio ligado, mostrando claramente que a legislação é infringida pelo responsável do veículo, por ausência da fiscalização e por falta de conhecimento da lei pelo condutor. Outro ponto infringido a legislação é o ponto 29, identificado no local a presença de uma creche municipal e justamente nesse local tem um veículo de propaganda fixo em um poste.

Torna-se notório que a falta de planejamento no da gestão municipal contribui para a poluição sonora devido a presença de escolas em zonas de alta concentração de ruído. Em virtude de que atualmente existem leis federais e estaduais de combate à poluição e que determinam medidas punitivas para quem venha a causar tal poluição essas falhas têm impacto direto na população presente no núcleo urbano, pois desencadeia diversos problemas de saúde como fadiga, irritabilidade, distúrbios do sono, doenças cardiovasculares, e o nível cognitivos prejudicado (VAN KAMP, 2013). 
Logo evidenciou-se que a comunidade local apresenta ausência de informações quanto à importância dos níveis de poluição sonora adequado para a saúde e qualidade de vida, não sabendo ao certo quais os principais efeitos nocivos para a saúde humana.

Percebe que o município de Capanema/PA se tem uma deficiência do poder público, devido ao município não contar com um programa de fiscalização para combater à poluição sonora que seria liderado pela Secretária Municipal de Meio Ambiente - SEMMA juntamente em parceria com outros órgãos de fiscalização.

O município não conta com uma Delegacia Especializada em Meio Ambiente - DEMA que seria responsável especificamente para assuntos pertinentes ao meio ambiente, que deixa a população à mercê de não saber a quem acionar.

Atualmente, diversas cidades no âmbito nacional já tomaram providências em relação aos impactos da poluição sonora e criaram políticas públicas para combatê-lo, como por exemplo a cidade de Fortaleza no estado do Ceará, que criou a "Lei do Silêncio" possibilitando fiscalizações mais intensas e a população mais consciente sobre os limites permitidos. Também a prefeitura da cidade de São Paulo instituiu a "Lei do PSIU" um Programa de Silêncio Urbano para tornar mais pacífica a convivência entre os cidadãos e atender os preceitos constitucionais.

No Âmbito estadual, a Câmara Municipal de Belém instituiu a Lei 7990/2000 que dispõe sobre o Controle e o Combate à Poluição Sonora no Âmbito do Município (Belém, 2000), o limite máximo em decibéis, medido no limite real de propriedade, é de $70 \mathrm{~dB}(\mathrm{~A})$ durante o dia e $60 \mathrm{~dB}(\mathrm{~A})$ durante a noite. - a partir dessa Lei as medidas de fiscalização são realizadas em parcerias com participação Guarda Municipal de Belém - GMB, Superintendência Executiva de Mobilidade Urbana de Belém - SeMOB, Departamento de Trânsito do Estado do Estado do Pará - Detran, Delegacia Especializada em Meio Ambiente - DEMA e Divisão de Polícia Administrativa - DPA.

Em 2016 a Secretária Municipal de Meio Ambiente do município de Marabá, no sudeste do Pará, criou um canal para reclamações sobre poluição sonora, com intuito da população saber a quem procurar para reclamar seus direitos (ALVES, 2016).

O Ministério Público do Estado do Pará - MPPA está expedindo recomendações para cidades onde é constatado altas reclamações, no dia 14 de agosto de 2018 o Ministério Público do Estado do Pará - MPPA expediu recomendações para o município de Jacundá localizado no sudeste do Pará, devido a falha da administração pública em relação ao combate da poluição sonora, onde recomendou que a o Comandante da Polícia Militar de Jacundá que determine a seus subordinados fazerem a apreensão imediata de instrumentos sonoros eventualmente utilizados para praticar a contravenção penal do Artigo no 42 do Decreto Lei no 3.688/41 (CALIXTO, 2018).

Recentemente em 21 de fevereiro de 2019 o Ministério Público do Estado do Pará - MPPA institui recomendações de combate à poluição sonora para o município de Santarém que fica localizado a oeste do estado do Pará, onde nessa recomendação diz respeito a fiscalização de estabelecimento comercial que utilizem equipamentos sonoros ao ar livre incluindo calçadas (SANTARÉM, 2019).

É perceptível que o combate da poluição sonora pelo poder público do município de Capanema/PA não está acontecendo de forma eficaz, evidenciado no estudo os níveis de pressão sonora está acima do que é estabelecido pela legislação e os órgãos competentes não tem medidas de mitigação, onde o plano diretor do município está desatualizado e a falha no ordenamento territorial sendo evidente quando se identificou uma Creche municipal em um ponto com níveis elevados em desacordo com a legislação vigente.

Como visto anteriormente à ineficiência do poder público perante as questões de controle da poluição sonora a exemplo do município de Santarém e Jacundá situados no estado do Pará, fez com que o Ministério Público entrasse em ação propondo medidas para combate à poluição sonora. Para que não aconteça o mesmo com o Município de Capanema/PA os órgãos competentes como a SEMMA, Prefeitura, Polícia Civil, Polícia Militar e DEMUTRAN tem que estabelecer parceria e para que sejam realizadas as medidas para combate à poluição sonora no município.

Além disso, verificou-se a presença constante de motos com escapamento irregular, com a ausência da fiscalização de trânsito devido os veículos circularem livremente com condutores sem capacete infringindo a Lei 9.503 de 23 de setembro de 1997 do Código de Trânsito Brasileiro (CTB).

Constatou-se que em virtude da alta rotatividade dos servidores municipais devido a questões políticas fez com que tivesse uma descontinuação das medidas de controle ambiental, mas com a chamada dos aprovados do último concurso realizado no município e a capacitação deles esse cenário tende a mudar. 
Então, constatamos que essas zonas se influenciam devido ao curto espaço de transição entre elas, onde evidenciamos a presença de uma área comercial no ponto 29 e nas suas proximidades observou-se a existência de uma área residencial, que diante dos dados obtidos pelo mapa acústico e o $L_{A e q}$, logo, identificou-se que essa área sofre com a poluição sonora.

Além do mais, comprovamos a falha no ordenamento territorial do município que está infringindo a Lei Federal e Municipal com a presença de uma creche municipal perto de um centro comercial com grande tráfego de pessoas, veículos automotores e de propaganda e publicidade onde detectou-se elevados índices de ruídos, conforme evidenciado na. Se tornando prejudicial para as crianças que se encontram no interior da instituição, pois são um grupo vulnerável, que de acordo com Van Kamp, (2013) o ruído é prejudicial para o nível cognitivo e o processo de aprendizado.

Importante ressaltar que os veículos de transportes considerados de grande porte não trafegam pela mesma via que é responsável pelo escoamento da produção mineral, ou seja não fazem uso da Avenida Senador Jarbas Passarinho, construída especificamente para a circulação de veículos pesado, a qual poderia receber tal demanda, visando reduzir os elevados índices de ruídos observados na avenida João Paulo II, onde há a presença de hospitais, escolas, supermercados, creches e outros que por lei não deveria estar sob pressão sonora irregular.

\section{CONCLUSÃO}

Dessa forma, foi identificado que o os níveis de pressão sonora equivalente no município de Capanema, no Estado do Pará, apresentaram que em $97 \%$ dos pontos estudados estão fora dos padrões estabelecidos na legislação e normas tanto municipal quanto federal, constatando que o núcleo urbano sofre demasiadamente com a poluição sonora. Com a espacialização dos níveis acústicos no núcleo urbano, observou-se que os maiores pontos de incidência de ruído estão presentes nas zonas comerciais e zonas mista com a presença de residência.

O teste dos métodos de interpolação estabeleceu que o Spline apresentou o melhor resultado para a modelagem dos níveis de pressão sonora no presente estudo.

Como o núcleo urbano do município de Capanema-PA sofre com a poluição sonora, a população presente nesta zona tem a sua saúde prejudicada por causa de tal impacto como, prejuízo aos níveis cognitivos, auditivos, pressão alta, stress.

Por isso, destaca-se com base nos produtos adquiridos e com o intuito de contribuir com soluções para o problema aqui exposto, na esperança de auxiliar o município ao processo de adequação legal e judicial através da criação e concretização de medidas mitigadoras para o combate da poluição sonora e melhor qualidade de vida da população. Este estudo sugere medidas propostas a serem realizadas, visando promover os ajustes necessários ao cenário atual, atenuando assim os níveis de pressão sonora.

Sendo assim, sugere-se que para o desenvolvimento de trabalhos futuros sejam abordados aspectos altamente relevantes, tais como:

- Ao DEMUTRAN, intensificar as fiscalizações dos veículos automotores, principalmente motos com escapamentos irregulares;

- Reduzir a velocidade da via principalmente perto dos hospitais, escolas e áreas residenciais;

- Aplicação da Legislação Federal e municipal para controle de poluição, através da definição de números fixos e formais para denúncias, com funcionalidade de 24 horas e em tempo integral;

- Promover para a população a educação ambiental sobre os malefícios causados pela poluição sonora, e realizar o processo de monitoramento e fiscalização em parceria.

- Licenciar, fiscalizar e monitorar não somente os veículos de propaganda, bem como os veículos de lazer presentes no município;

- Realizar medidas para o ordenamento territorial adequado especificamente de escola, creches e hospitais, deixando-os em localização adequada, conforme exige a lei municipal de poluição sonora;

- Analisar a presença, bem como necessidade e viabilidade dos semáforos presentes nos pontos (4; 29) para evitar a aglomeração de veículos o que identifica os níveis sonoros elevados e fora do permitido por lei presente em tempo significativo nesta área, tornando-a como crítica; 
- Capacitar os novos servidores da SEMMA para o combate à poluição sonora, através do processo de capacitação, treinamentos, instruções de medição, controle, analise, abordagem e fiscalização;

- A SEMMA fechar parceria com a secretaria de segurança pública do estado do Pará, através da polícia civil e militar, visando a implantação de um posto consolidado da Delegacia de Meio Ambiente DEMA no município, bem como o estreitamento dos laços e ações do Instituto Renato chaves, através do monitoramento e perícia criminal de poluição sonora efetiva;

- Parceria da prefeitura de Capanema, através da secretaria municipal de meio ambiente com a universidade federal rural da Amazônia- UFRA, através do curso de graduação em Engenharia Ambiental para o desenvolvimento de novos estudos no município sobre os níveis de pressão sonora, e a viabilidade de treinamentos e capacitação técnica específica;

- Criar um plano de tráfego no município para limitar o trânsito de veículos de grande porte a áreas de grandes especificidades, como os hospitais, centros e postos de saúde, escolas, creches, asilos, etc.

- Realizar um levantamento sobre o que a população entende sobre poluição sonora com aplicação de questionários;

- Desenvolver um estudo sobre o comportamento específico das áreas presentes no núcleo urbano;

- Realizar o mapeamento sonoro de todo o município de Capanema/PA e de forma temporal, visando compreender a forma como o crescimento urbano demográfico é responsável pelo aumento dos níveis de pressão sonora.

\section{REFERÊNCIAS}

[1] ABNT- Associação Brasileira de Normas Técnicas NBR. 10151. Acústica-Avaliação do ruído em áreas habitadas, visando o conforto da comunidade-Procedimento, Associação Brasileira de Normas Técnicas, 2000.

[2] ALVES, Jaqueline. POLUIÇÃO SONORA: SEMMA DISPONIBILIZA CANAL PARA DENÚNCIA EM MARABÁ. Naturezabelavida, 2016. Disponível em: < http://www.naturezabelavida.com.br/poluicao-sonora-semmadisponibiliza-canal-para-denuncia-em-maraba/> . Acesso em 07 de Jul. de 2019.

[3] AMORIM, Adriana Eloá Bento et al. Previsão do ruído ambiental urbano devido à implantação do Modal Veículo Leve sobre Trilhos (VLT) por meio de simulação computacional. Interações (Campo Grande), v. 18, n. 4, p. 81$97,2017$.

[4] ARCHELA, Rosely Sampaio; ARCHELA, Edison. Síntese cronológica da cartografia no Brasil. Portal de Cartografia das Geociências, v. 1, n. 1, p. 93-110, 2008.

[5] BARROS, C. J. O. Análise espacial do controle da poluição sonora em Belo Horizonte. ENCONTRO DA SOCIEDADE BRASILEIRA DE ACÚSTICA, v. 19, p. 380-385, 2000.

[6] BELÉM, Lei № 7990 de 10 de Janeiro de 2000, Belém, Pa, 2000, Disponível em < https://leismunicipais.com.br/a/pa/b/belem/lei-ordinaria/2000/799/7990/lei-ordinaria-n-7990-2000-dispoesobre-o-controle-e-o-combate-a-poluicao-sonora-no-ambito-do-municipio-de-belem>; Acesso em: 07 de Julho de 2019.

[7] BRASIL Lei no 3.688 de 03 de outubro de 1941- Lei de Contravenções Penais, Brasília, DF,1941. Disponível em < http://www.planalto.gov.br/ccivil_03/decreto-lei/del3688.htm>. Acesso em: 23 Jun, 2019.

[8] ___ Constituição Da República Federativa Do Brasil De 1988-Brasilia, DF, 1988. Disponível em: < http://www.planalto.gov.br/ccivil_03/constituicao/constituicaocompilado.htm>. Acesso em: 23 Jun, 2019.

[9] ___. Lei no 9.503, de 23 de setembro de 1997 Código de Transito Brasileiro Brasília, DF, 1997 Disponível em http://www.planalto.gov.br/ccivil_03/leis/19503.htm >. Acesso em: 23 Jun, 2019.

[10] __ Ministério do Planejamento, Orçamento e Gestão. Instituto Brasileiro de Geografia e Estatística. Contagem Populacional. Disponivel em: <https://cidades.ibge.gov.br/brasil/pa/capanema/panorama>.Acesso em: jan. 2019

[11] CAPANEMA, Lei 6.350 de 15 dezembro de 2014, Medições de sossego público e combate a poluição sonora, Capanema, 2014. Disponível em. <https://www.capanema.pa.gov.br/leis.php?car=13>. Acesso em 15 maio de 2019.

[12] CAMARGO, E. C. G. Desenvolvimento, implementação e teste de procedimentos geoestatisticos (Krigagem) no sistema de processamento de informações georreferenciadas (Spring). São José dos Campos, 1997.

[13] CABRAL, Célia Morais. Acústica Industrial: aplicação da análise de vibrações e ruído à identificação de fontes de ruído em ambiente industrial. 2012. Dissertação de Mestrado. 
[14] CABRAL, Pedro Ivo Decurcio; PERÍCIA, Auditoria; AMBIENTAL, Governança. Arborização urbana: problemas e benefícios. Revista Especialize On-line IPOG, Goiânia, n. 06, p. 1-15, 2013.

[15] CALIXTO, Sue Anne, Promotoria recomenda à PM combate contra poluição sonora. Ministério Público do Estado do Pará, 2018. Disponível em: < https://www2.mppa.mp.br/noticias/promotoria-recomenda-a-pm-combatecontra-poluicao-sonora.htm>. Acesso em Acesso em 07 de Jul. de 2019.

[16] DE MELO, Ricardo Almeida et al. Previsão do nível de ruído gerado pelo tráfego de veículos na cidade de João Pessoa, Brasil. 2010.

[17] DOS SANTOS GALVANIN, Edinéia Aparecida; DAL POZ, Aluir Porfírio. Sistema lidar e métodos de interpolação de dados. Revista de Geografia (UFPE), v. 30, n. 1, 2013.

[18] FARIAS, Orlindo Gomes; FRANCISCO, Cristiane Nunes; SENNA, Monica Carneiro Alves. AVALIAÇÃO DE MÉTODOS DE INTERPOLAÇÃO ESPACIAL APLICADOS À PLUVIOSIDADE EM REGIÃO MONTANHOSO NO LITORAL SUL DO ESTADO RIO DE JANEIRO. Revista Brasileira de Climatologia, v. 21, 2017.

[19] FIORILlo, Celso Antonio Pacheco. Curso de direito ambiental brasileiro. rev., atual. e ampl. São Paulo: Saraiva, 2012.

[20] GERGES, Samir NY. Ruído: fundamentos e controle. In: Ruído: fundamentos e controle. 1992.

[21] GERGES, Samir NY. Ruído: fundamentos e controle. In: Ruído: fundamentos e controle. 2 ed.2000.

[22] GUEDES, Italo Cesar Montalvão et al. Influência da forma urbana em ambiente sonoro: Um estudo no bairro Jardins em Aracaju (SE). 2005.

[23] JAKOB, Alberto Augusto Eichman; YOUNG, Andrea Ferraz. 0 uso de métodos de interpolação espacial de dados nas análises sociodemográficas. Anais, p. 1-22, 2016.

[24] MENDONÇA, André Bressa Donato et al. Medições acústicas: variação da geometria da via urbana e tempo de amostragem. In: III Simpósio de Pós Graduação em Engenharia Urbana. 2012.

[25] MOURA, Vania Raposo; DE MELO, Gustavo da Silva Vieira; SANTOS, Wagner Sousa. Ruído e configuração espacial urbana: um estudo de caso na cidade de Belém do Pará. PARC Pesquisa em Arquitetura e Construção, v. 7, n. 4, p. 237-251, 2016.

[26] PARÁ, Constituição Estadual De 5 De Outubro De 1989. Belém, PA, 1989. Disponível em < https://www.sistemas.pa.gov.br/sisleis/legislacao/228> Acesso em: 03 Jun, 2019.

[27]__ Lei Estadual no 588709 de Maio de 1995. Política Estadual Do Meio Ambiente. Belém, PA, 1995. Disponível em < https://www.semas.pa.gov.br/1995/05/09/9741/> Acesso em: 03 Jun, 2019.

[28] PRESUMIDO, Pedro Henrique et al. Projeto Rehabind-Qualidade ambiental em áreas industriais transfronteiriças-Mirandela e Zamora (Espanha). In: Livro de Atas da Conferência Internacional de Ambiente em Língua Portuguesa. Universidade de Aveiro, 2018. p. 21-24.

[29] SANTARÉM, G1, MPPA recomenda medidas para combate à poluição sonora em Santarém, G1 Santarém, 2019, Disponível em <https://g1.globo.com/pa/santarem-regiao/noticia/2019/03/01/mppa-recomenda-medidaspara-combate-a-poluicao-sonora-em-santarem.ghtml>. Acesso em Acesso em 07 de Jul. de 2019.

[30] SCHENATTO, Kelyn et al. Utilização de métodos de interpolação e agrupamento para definição de unidades de manejo em agricultura de precisão. 2014.

[31] SANTOS, Luís Conde; VALADO, Fátima. O mapa de ruído municipal como ferramenta de planeamento. Acústica, 2004.

[32] VASKOR, J. G.; DICKINSON, S. M.; BRADLEY, J. S. Effect of sampling on the statistical descriptors of traffic noise. Applied Acoustics, v. 12, n. 2, p. 111-124, 1979.

[33] VENTURA, Judite. Modelação do Ruído Ambiente no Campus da ESTG. Comparação entre a utilização de uma técnica geoestatística (Kriging) e software de previsão acústica. Acústica, Coimbra, v. 22, 2008.

[34] VAN KAMP, Irene et al. Noise and health in vulnerable groups: a review. Noise and health, v. 15, n. 64, p. 153,

2013

[35] WORLD HEALTH ORGANIZATION et al. European Commission: Burden of Disease from Environmental Noise: Quantification of Healthy Life Years Lost in Europe. The WHO European Centre for Environment and Health, 2011.

[36] World Health Organization, Regional office for Europe. Burden of disease from environmental noise Quantification of healthy life years lost in Europe. 2011 Copenhagen.

[37] ZANNIN, Paulo Henrique Trombetta; FERRAZ, Fernanda. Assessment of indoor and outdoor noise pollution at a university hospital based on acoustic measurements and noise mapping. Open Journal of Acoustics, v. 6, n. 4, 2016. 


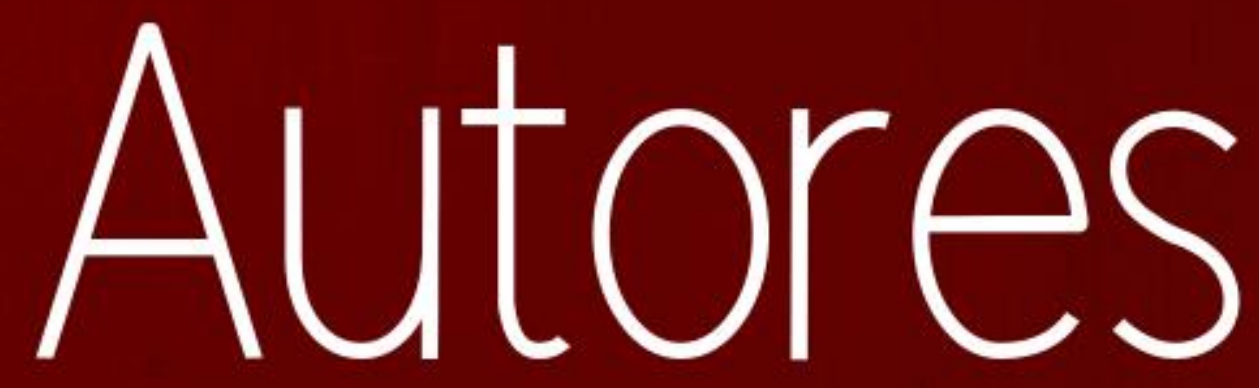




\section{FABIANE DOS SANTOS (ORGANIZADORA)}

Possui graduação em Geografia (Licenciatura e Bacharelado) pela Universidade Federal de Uberlândia, mestrado em geografia pela Universidade Federal de Uberlândia. Tem experiência na área de Geociências, com ênfase em Geografia ambiental, atuando principalmente nos seguintes temas: áreas verdes, índice de áreas verdes, espaços públicos livres e parques urbanos.

\section{ABILIO SILVA NUNES}

Formação: Engenharia Civil, Cursos: Técnico Quimica, Experiência profissional: Monitoria de Qualidade

\section{ADMILSON İRIO RIBEIRO}

Bacharel em Engenharia Agrícola pela Universidade Federal de Lavras-UFLA, Mestre e Doutor Engenharia Agrícola pela Faculdade de Engenharia Agrícola FEAGRI UNICAMP e Pós-Doutor em Environmental Science, Department of Environmental Science - University of California-RiversideUCR. Atua como Professor Assistente no Departamento de Engenharia Ambiental no Instituto de Ciência e Tecnologia UNESP-Sorocaba, onde pesquisa e orienta no Programa de Pós-Graduação em e Ciências Ambientais dentro das temáticas das disciplinas: Avaliação de Danos e Impactos Ambientais e Recuperação de Áreas Degradadas.

\section{ADRIANO REIS DE PAULA E SILVA}

Mestre em Geografia pelo Instituto de Geografia da Universidade Federal de Uberlândia (IG/UFU). Especialista em Gestão e Docência no Ensino Superior pela Faculdade do Noroeste de Minas GeraisFINOM. Graduado em Engenharia Civil pela Fundação Educacional de Barretos (FEB). Professor da Universidade do Estado de Minas Gerais - UEMG/Frutal

\section{ALINE APARECIDA PEREIRA}

Graduada em Tecnologia em Meio Ambiente e Recursos Hídricos pela Faculdade de Tecnologia de Jahu (FATEC) do Centro Paula Souza e, atualmente, graduanda em Engenharia Ambiental pela Universidade Federal do Triangulo Mineiro (UFTM). Envolvida em diversos projetos de educação ambiental com a comunidade.

\section{ALINE NUNES DE SOUZA}

Geógrafa licenciada pela Universidade do Estado de Minas Gerais (UEMG), Licenciada em Pedagogia pela FATECE e Especialista em Docência do Ensino Superior. Professora efetiva na Rede Municipal de ensino e Educadora Ambiental na Secretaria Municipal de Meio Ambiente de Frutal-MG.

\section{AMANDA CERQUEIRA DOS SANTOS}

Atualmente se graduando em Biomedicina pela Faculdade Integrada Einstein de Limeira. Realizou um curso de Aprendizagem Industrial de Eletricista de Manutenção e Eletroeletrônica na escola SENAI Luiz Varga. Tem grande interesse na área de pesquisa. Participou como autor do artigo Biopirataria no 17을 Congresso Nacional de Meio Ambiente de Poços de Caldas, realizado no período de 23 e 24 de setembro de 2020 (100\% on-line).

\section{AMANDA RAMOS PAULETTO}

A autora possui mestrado em Engenharia Civil pela Universidade do Vale do Rio dos Sinos (UNISINOS) e graduação em Engenharia Civil pela mesma instituição. Possui experiência nas áreas de controle tecnológico do concreto, projetos, desenho técnico e planejamento. Membro do Núcleo de Caracterização de Materiais (NucMat). Realiza pesquisas com foco em caracterização química e 
microestrutural de materiais de construção civil, especialmente em análise de Difração de Raios X (DRX) através do método de Rietveld.

\section{AMAURI JOSÉ PEREIRA}

Biólogo (Universidade Federal do Pará, Brasil), mestre em Biociências pela (Universidade Federal do Oeste do Pará).

\section{BÁRBARA MARIA BORGES RIBEIRO}

Engenheira Química, graduada em 2013 pela Universidade Metodista de Piracicaba (UNIMEP). Mestre em Engenharia Química (2017) pela Universidade Estadual de campinas (UNICAMP). Atualmente desenvolve sua tese de doutorado em Engenharia Química na UNICAMP. Atua na área de Engenharia de Processos, pesquisando os seguintes temas: incineração catalítica para degradação de compostos orgânicos voláteis (COVs), fotocatálise heterogênea para degradação de COVs, reaproveitamento de resíduos sólidos da construção civil para tratamento de efluentes líquidos. Integra o quadro docente dos cursos de Administração de Empresas, Arquitetura e Urbanismo, Biomedicina, Ciências Contábeis, Engenharia Civil, Engenharia de Produção, Engenharia Mecânica e Psicologia das Faculdades Integradas Einstein de Limeira.

\section{BENEDITO APARECIDO DE CASTRO}

Graduado em Agronomia pela Universidade Vale do Rio Verde (UNINCOR). Mestrando em Sustentabilidade em Recursos Hídricos pela UNINCOR. Já atuou como diretor comercial em empresas de vários segmentos. Atualmente é proprietário e atua como diretor geral na empresa MGSOL ENERGIA SOLAR FOTOVOLTAICA. Interessa- se por levar conhecimentos adquiridos ao longo dos anos para o meio acadêmico.

\section{BRENDA SILVA SOARES}

Graduanda em Tecnologia em Gestão Ambiental pela Universidade Federal de Viçosa - Campus Florestal

\section{CAMILA FERREIRA RIBEIRO}

Acadêmica de Direito na Universidade Federal de Rondônia e Membro do Grupo de Pesquisa em Direito Animal da UFSM (GPDA/UFSM).

\section{CAROLINE CAMPELO DA SILVA RIBEIRO}

Com Formação em Tecnologia em Horticultura, trabalhou na FAETEC, ministrando aulas de técnicas agrícolas para o ensino fundamental II, nas disciplinas de culturas, administração e economia rural, para o curso Técnico em Agropecuária e entomologia agrícola para o curso Técnico em Florestas, ambos na Escola Técnica Estadual Agrícola Antônio Sarlo. Também ministrou aulas de Ciências Agrárias para jovens e adultos no programa Projovem Campo Saberes da Terra, pela Prefeitura Municipal de Campos.

\section{CINTIA MARANGONI}

Possui graduação em Engenharia Química pela Fundação Universidade Regional de Blumenau, mestrado, doutorado e pós-doutorado em Engenharia Química pela Universidade Federal de Santa Catarina. Atualmente é professora do departamento de Engenharia Química e Engenharia de Alimentos e membro dos Programas de Pós-Graduação em Engenharia Têxtil e em Engenharia Química da referida universidade. Tem experiência as áreas de processos industriais da engenharia química com ênfase em destilação, processos de separação com membranas, reaproveitamente de resíduos sólidos. 


\section{DANISLEI BERTONI}

Licenciado em Biologia (Faculdades Integradas Espírita), mestrado/doutorado em Educação (UFPR) e professor da Licenciatura em Ciências Biológicas e do Mestrado em Ensino de Ciência e Tecnologia (UTFPR Campus Ponta Grossa). Experiência como professor da Educação Básica (SEED/PR), professor de Ciências no Ensino Fundamental (Araucária/PR), professor de Ciências/Biologia na rede particular, professor substituto de Metodologia e Prática de Ensino/Estágio Supervisionado em Ciências e em Biologia (UFPR) e docente em cursos de formação de professores (SEED/PR e UTFPR). Atualmente, integro o Comitê de Ética em Pesquisa envolvendo Seres Humanos (UTFPR), atuo como Editor da RBECT e participo em projetos de pesquisa e extensão.

\section{DIOGO CAIO ROCHA AMORIM}

Geógrafo e Agrimensor, pós-graduado em Geoprocessamento e processos para Internet na modalidade Lato-Sensu pela PUC Minas e Mestre em Engenharia Ambiental pela UFSC; Atua Como Geógrafo Coordenador da área técnica de Geoprocessamento na empresa Geoid Laser Mapping responsável por coordenar projetos de importância nacional e internacional como mapeamento da bacia hidrográfica do Rio Madeira, Mapeamento de diversas áreas do bioma amazônico e coordenação de projetos topográficos e as built para linhas de transmissão; Trabalha como Consultor da empresa Urbe Projetos Socioambientais, responsável pela Implantação do Sistema de Geoprocessamento da prefeitura de Contagem - MG. Atualmente é professor da Universidade Estadual de Minas Gerais - UEMG, lecionando disciplina de Geoprocessamento. Atua também como professor no Centro Universitário UNA lecionando as disciplinas de Topografia, Mecânica dos Solos , Obras e Terraplanagem, Projeto de Estradas e Saneamento Básico.

\section{EDUARDA CRISTINA DA VINHA}

Possui curso teórico-prático de Coleta de Sangue e Banco de Sangue pela Faculdades Integradas Einstein de Limeira (FIEL). Atualmente graduando Biomedicina pelas Faculdades Einstein de Limeira. Tem interesse na área de pesquisa científica. Participou como autor do artigo Biopirataria no $17^{\circ}$ Congresso Nacional de Meio Ambiente de Poços de Caldas, realizado no período de 23 e 24 de setembro de 2020 (100\% on-line) .

\section{EDUARDA RANDEL GUIMARÃES SOUZA}

Graduanda no curso de bacharelado em Biomedicina pela Universidade do Estado do Pará/UEPA. Hodiernamente é bolsista do Programa de Educação pelo Trabalho para a Saúde - PET-Saúde e membro do Centro Acadêmico de Biomedicina Evandro Chagas (CABEC) da Universidade do Estado do Pará, especificamente na comissão de politica e cultura. Tem experiência na área de Medicina, com ênfase em anatomia humana, atua na liga de Anatomia Humana (LAAHP) vinculada ao instituto de ciências biológicas da universidade federal do pará (ICB - UFPA) imcubida na Diretoria de Estágios, promovendo atividades de ensino, pesquisa e extensão voltados para a comunidade local, além de participar na criação peças anatômicas a partir da tecnologia 3D para o laboratório de Anatomia Humana (ICB). Estagia voluntariamente no Laboratório de Pesquisas em Estresse Oxidativo (LAPEO), no Laboratório de Virologia (LabVir) do Instituto de Ciências Biológicas (ICB) da Universidade Federal do Pará (UFPA) e no Instituto Médico Legal (IML) estabelecido no Centro de Perícias Científicas Renato Chaves (CPCRC).

\section{ELIANA GOMES DE PAULA E SILVA}

Geógrafa licenciada pelo Centro Universitário do Norte Paulista (UNORP), Especialista em Gestão Ambiental da Faculdade Católica de Uberlândia, área de concentração "Gestão Ambiental e Sustentabilidade". Professora na Rede Municipal de Educação da Prefeitura Municipal de Frutal/MG. 


\section{EMILLY DA SILVA FARIAS}

Bacharel interdisciplinar em Ciências com ênfase em Ciências Agrárias pela Universidade Federal do Sul da Bahia, pós-graduada em Gestão, Auditoria e licenciamento Ambiental e em Estatística Aplica, pela Universidade Norte do Paraná. Atualmente, mestranda na Universidade Federal do Sul da Bahia, no Programa de Pós-Graduação em Ciências e Tecnologias Ambientais. Possui conhecimentos em sistemas de informações geográficas, recursos hídricos e sistemas agroflorestais, com aptidão em softwares de geoprocessamento.

\section{EULA PAULA OLIVEIRA SILVA}

Ensino Superior - Engenharia Civil - Andamento, Centro Universitário UNA Previsão de Conclusão: Dezembro/2020, Curso nível intermediário de informática pela IFMG/Betim; Excel intermediário; Conhecimento intermediário em AutoCAD; Conhecimento intermediário em Sketchup; Projeto de Extensão/2020 aprovado no 17ํㅡㄴ Congresso Nacional de Meio Ambiente de Poços de Caldas: "Análise de Risco e Susceptibilidade e Erosão com auxílio do Sensoriamento Remoto em Betim/MG.

\section{EVELLEM VITÓRIA DE SOUZA FREITAS}

Acadêmica de Biomedicina da Universidade do Estado do Pará. Atualmente é integrante do Centro Acadêmico de Biomedicina Evandro Chagas (CABEC)

\section{FÁBIO RODRIGUES SILVA}

Mestre em Matemática Aplicada pela Universidade Estadual de Campinas (2016). Bacharel em Matemática pela Universidade Federal de Uberlândia (2013). Técnico em Química pelo Instituto Federal de Educação, Ciência e Tecnologia do Triângulo Mineiro (2013). Aluno do Programa de PósGraduação em Matemática Aplicada, nível doutorado, da Universidade Estadual de Campinas e Professor de Educação Superior da Universidade do Estado de Minas Gerais (UEMG), Unidade Frutal.

\section{FERNANDA GOMES LINHARES}

Graduação em Ciências da Natureza com Licenciatura em Física pelo Instituto Federal Fluminense (2013). Atuou como bolsista do Programa de Educação Tutorial (PET) Ciências da Natureza do IF Fluminense (2010-2013). Mestrado em Ciências Naturais pela Universidade Estadual do Norte Fluminense Darcy Ribeiro (UENF) (2015), no qual trabalhou com detecção de gases poluentes derivados da combustão em motores Diesel. Doutorado em Ciências Naturais pela UENF (2019) na área de Ciências Ambientais, cujo tema foi a detecção fotoacústica de gases a partir de diferentes fontes de radiação laser (laser de cascata quântica e laser de diodo simples) aplicados à Avicultura de corte. Atualmente é Bolsista de Pós-doutorado Recém doutor Temático Agenda 2030 (Edital 03/2019 UENF), trabalhando com a detecção de gases em diferentes sistemas de criação na produção avícola. Sua área de interesse é aplicação da técnica fotoacústica para detecção de gases, tendo como principal atuação o estudo dos gases provenientes da Avicultura, tais como amônia (NH3) o qual pode afetar o bem estar das aves, e os gases estufa metano (CH4) e óxido nitroso (N2O) provenientes da compostagem da cama.

\section{FRANCISCO GIOVANI SOUZA LAÉRCIO}

Graduado em Licenciatura Matemática e Física pela Universidade do Estado de Minas Gerais. Possui cursos de extensão na área de Educação. Pós Graduação em Ensino de Física pela UNESP e Pós Graduação em Ensino de Matemática pela UNICAMP. Cursos de extensão na área de Meio Ambiente e Sustentabilidade como Geoprocessamento, Desenvolvimento Sustentável e Bacia Hidrográficas. Autor de livros sobre Gestão de Recursos Hídricos pela Universidade de Taubaté. Atualmente Professor II na Rede Estadual de Ensino de São Paulo das disciplinas de Matemática, Física e Tecnologia da Inovação. Mestrando em Sustentabilidade e Recursos Hídricos pela UNINCOR com projeto em ações de sustentabilidade e Educação Ambiental para o ambiente escolar. 


\section{GABRIEL OLIVEIRA ROQUE}

Estudante de Engenharia Elétrica, cursando quarto semestre na instituição FIEL (Faculdade Integradas Einstein de Limeira).

\section{GABRIELA SIMON}

Graduanda do curso de Engenharia Têxtil da Universidade Federal de Santa Catarina do Campus Blumenau. Foi bolsista PIBIC do CNPq, atuando no projeto de pesquisa intitulado "Emprego de destilação por membranas para o tratamento de efluente da indústria têxtil"

\section{GABRIELLE CUSTÓDIO MELO}

Aluna do Curso de Bacharelado em Agroecologia, Universidade Estadual da Paraíba (UEPB), Departamento de Agroecologia e Agropecuária.

\section{GERSON ARAÚJO DE MEDEIROS}

Graduado em Engenharia Agrícola, Mestre e Doutor em Engenharia de Água e Solo pela Universidade Estadual de Campinas (UNICAMP). Em 2015 e 2018 realizou períodos de intercâmbio respectivamente na Universidade de Alberta (UofA), no Canadá, e na Universitat Autônoma de Barcelona (UAB), na Espanha. Desde 2011 é professor na Universidade Estadual Paulista (UNESP), Campus de Sorocaba, no curso de graduação em Engenharia Ambiental e no Programa de Pós Graduação em Ciências Ambientais. Nesses cursos tem atuado na área de Gestão Ambiental, orientando pesquisas sobre gestão de recursos naturais e antropizados.

\section{GRACIELA FLÁVIA HACK}

Possui graduação em Direito pela Fundação Universidade Federal de Rondônia, Campus de Cacoal (2004). Especialista em Direito Tributário pela Universidade da Amazônia, Belém, Pará (2007) e em Direito Público pela Universidade Anhanguera-Uniderp (2009). Atuou com Assistente de Promotoria na $1^{\mathrm{a}}$ Promotoria de Justiça de Cacoal, $1^{\underline{a}}$ Titularidade, Curadoria do Meio Ambiente (2011 e 2012), e como Analista Processual na Promotoria de Justiça de Cacoal (2012 a 2015), no Ministério Público do Estado de Rondônia. Atualmente, é docente, em regimente de dedicação exclusiva, da Fundação Universidade Federal de Rondônia - UNIR, lotada no Departamento Acadêmico de Direito de Cacoal. Tem experiência na área de Direito, com ênfase em Direito Público. Desenvolve pesquisas relacionadas ao Meio Ambiente.

\section{GUILHERME COELHO ARAUJO}

Cursando Graduação em Engenharia Civil UNA Betim - (10º Semestre) Conclusão em 07/2021. Manutenção Mecânica Industrial SENAI MG - Concluído em 01/2015. Robótica Industrial Ramacrisna - Concluído em 06/2018, Desenvolvimento Profissional Brigadista - Total Seg; Alvenaria Estrutural - Arthur Moreira Bomtempo; Soluções para Cidades Inteligentes - UNA Betim; Leitura e Interpretação de Desenho Técnico- SCI BRASIL; Quantitativo Automático e Listas Automáticas-GMaster Treinamentos; Autocad 2D e 3D - Ronaldo Carreta; Eberick | Estruturas de Concreto Armado -Renann Augusto Wolbert; Revit para iniciantes - Ronaldo Carreta; VBA P/ Excel - Hashtag; Projeto Arquitetônico Passo a Passo no Autocad- Ronaldo Carreta; Libras - Básico; Excel Avançado; Pacote Office Avançado. BHS Construtora - Estagiário em Engenharia Civi 09/2020 a atual, Construção Civil. Responsável pela execução de projetos hidrossanitários, elétricos e estruturais de edificações residenciais de pequeno e médio porte. Engenheiro Lucas Soares - Estagiário em Engenharia Civil 01/2019 a 12/2020 Construção Civil. Responsável pelo apoio no desenvolvimento e acompanhamento dos projetos Estruturais e Hidráulicos de edifícios em concreto armado. Atuando na elaboração de memorial de cálculo, descritivos e lançamento de dados em sistema.

\section{GUILHERME RIBEIRO}


Mestre em Produção Vegetal; Técnico do Laboratório de Fitotecnia da UENF; Doutorando em Produção Vegetal na linha de pesquisa Química do Húmus.

\section{HYGOR ARISTIDES VICTOR ROSSONI}

Graduado em Engenharia Ambiental pela Universidade Federal de Viçosa (2005), mestre em Ciência Florestal pela mesma instituição (2007) e Doutor em Saneamento, Meio Ambiente e Recursos Hídricos pela Universidade Federal de Minas Gerais (2015). Atualmente é professor da Universidade Federal de Viçosa - Campus de Florestal. Tem experiência na área de Engenharia Sanitária e Ambiental, com ênfase em Controle da Poluição e Saneamento, atuando, principalmente, nos seguintes áreas temáticas: políticas públicas de saneamento, tratamento e reutilização de efluentes ou águas residuárias; gerenciamento de resíduos sólidos, monitoramento e controle ambiental e gerenciamento de recursos hídricos. Foi o primeiro coordenador do Curso Superior de Tecnologia em Gestão Ambiental e Diretor de Ensino da UFV - Campus de Florestal. Recentemente atua como membro do Núcleo Docente Estruturante (NDE) e Coordenador Suplente do Curso Superior de Tecnologia em Gestão Ambiental. Coordena as seguintes disciplinas: i) Controle Ambiental na Indústria; ii) Coleta e Tratamento de Águas Residuárias; iii) Gestão Ambiental; iv) Manejo e Tratamento de Poluentes; v) Ética e Atuação Profissional; vi) Qualidade da Água e Tratamento de Resíduos; vii) Sustentabilidade Ambiental e viii) Turismo e Meio Ambiente. Recentemente (2017) vem atuando como docente e orientador permanente do Programa de Pós-Graduação em Sustentabilidade e Tecnologia Ambiental (Mestrado Profissional) do Instituto Federal de Minas Gerais - Campus Bambuí, desenvolvendo trabalhos nas linhas de pesquisas referentes a Gestão e Planejamento Ambiental e Tecnologia Ambiental. As orientações estão sendo desenvolvidas nas seguintes áreas de interesses: i) Planejamento, Gestão e Avaliação de Políticas Públicas de Saneamento; ii) Tecnologias de Tratamentos de Águas de Abastecimento e Residuárias; e iii) Controle Ambiental em Processos Agrícolas e Industriais.

\section{IGOR DE SOUZA GOMIDE}

Engenheiro Ambiental formado em 2009 pela Universidade do Estado do Pará (UEPA). Possui Mestrado em Engenharia Civil pela Universidade Federal do Pará (UFPA), obtido em 2012, na linha de Pesquisa de Recursos Hídricos. Atualmente é Professor Efetivo da Universidade Federal Rural da Amazônia (UFRA - Campus Capanema/PA), Subcoordenador do Curso de Graduação em Engenharia Ambiental e Energias Renováveis (nota 5 no MEC) e membro do Grupo de Pesquisa em Água, Energia e Sustentabilidade da Amazônia (GAES), sendo aluno de Doutorado do Programa de Pós-Graduação em Engenharia de Recursos Naturais da Amazônia (PRODERNA) pela UFPA, na linha de pesquisa Meio Ambiente e Energia. A tese é em Desenvolvimento de Metodologia para Implantação de Parques Hidrocinéticos.

\section{JANE MARGARET COSTA DE FRONTIN WERNECK}

Possui graduação em Ciências Biológicas pela Universidade Santa Úrsula (1982), mestrado (1989) e doutorado (1997) em Biologia Parasitária pela Fundação Oswaldo Cruz. Pós-Doutorado pelo Centers for Disease Control and Prevention, Atlanta, GA USA (2003). Atualmente é Pesquisador Titular do Instituto Oswaldo Cruz - Fundação Oswaldo Cruz, Chefe Substituta do Laboratório de Biodiversidade Entomológica. Tem experiência na área de Zoologia, com ênfase em Morfologia dos Grupos Recentes, atuando principalmente nos seguintes temas: Vetores da Doença de Chagas, com enfoque principal no complexo Triatoma brasiliensis, Triatoma rubrovaria, Triatoma maculata. Curadoria, desenvolvimento e modernização de coleções entomológicas. É líder de grupo do CNPq, Orienta alunos de iniciação cientírica, especialização, mestrado e doutorado. Coordena disciplinas em cursos de pós-graduação stricto sensu no Instituto Oswaldo Cruz. Promove atividades de extensão, divulgação e educação científicas incentivando a acessibilidade e a inclusão social. Bolsista de Produtividade em Pesquisa do CNPq e Coordenadora da regiao serrana de Petropolis do Grupo Brasil Verde. 
Graduando em Engenharia Civil (08) na Universidade do Estado de Minas Gerais (UEMG), no campus de João Monlevade/MG. Membro da Liga Estudantil de Engenharia COLLIGARE desenvolvendo projetos acadêmicos e sociais, sendo que é de responsabilidade da Liga o evento da Semana de engenharia promovendo visitas técnicas, palestras, workshop e atividades que complementam o ensino das engenharias na universidade. Atualmente é bolsista do Programa de Apoio a Projetos de Extensão da UEMG - PAEX/UEMG no projeto AVALIAÇÃO DO POTENCIAL DE EROSÃO DO SOLO EM JOÃO MONLEVADEMG.

\section{JHENIFER STEFANY ELOI DE PAULO}

Graduada em Engenharia Civil pelo Centro Universitário Una campus Betim - 2020. Cursos: Técnico em administração - Genoma Betim - 2013, Processos administrativos - SESI SENAI Maria Madalena Nogueira/ Betim- 2015, Inglês - Prime English Academy (Betim/MG) Cursando Intermediário. Experiencia profissional: Manustral Industria e Comércio LTDA. - Auxiliar administrativo. | 2014 - 2014 Funções: Emissão de nota fiscal, vendas, compras. Dytech do Brasil Industria e Comércio LTDA. - Aprendiz assistente administrativo | 2014 - 2015 Funções: Aprendiz. Prefeitura Municipal de Betim. - Atendente de apoio pedagógico | 2017 - 2020 Funções: Acompanhamento de crianças deficientes no período das aulas. Diex Engenharia - Auxiliar de engenharia | Atualmente. Funções: Acompanhamento de obras, compras de materiais, pagamento os funcionários, etc.

\section{JOÃO BATISTA LOPES DA SILVA}

Professor na Universidade Federal do Sul da Bahia, Campus Paulo Freire (Teixeira de Freitas). Graduado em Engenharia Agrícola e Ambiental pela Universidade Federal de Viçosa (2004), Mestre em Engenharia Agrícola, na área de Recursos Hídricos e Ambientais, pela Universidade Federal de Viçosa (2006) e Doutor em Engenharia Agrícola pela Universidade Federal de Viçosa, na área de Recursos Hídricos e Ambientais (2010), Pós-Doutor em Meteorologia Agrícola pela Universidade Federal de Viçosa (2012).

\section{JOÃO PEDRO DE BARROS REICAO CORDIDO}

Possuo graduação em Engenharia Agronômica pela UNESP - FCAV (2010), Mestrado em Produção Vegetal pela UENF (2015) e Doutorado em Solos e Nutrição de Plantas pela UFV (2019). Tendo estudado adubação nitrogenada em coqueiros em solos extremamente arenosos (Espodossolo) e relações nutricionais e de clima em populações de eucalipto e sua produtividade através de banco de dados.

\section{JOSCÉLIA MONTEIRO SANTOS DE BRITO}

Licenciada em Letras pela Universidade do Estado da Bahia (UNEB) em 2007, com pós-graduação latu senso em Gestão Pública (2011) e, atualmente mestranda do Programa de Pós-Graduação em Ciências e Tecnologias Ambientais pela Universidade do Sul da Bahia (UFSB), com pesquisa voltada para linha Gestão, Política e Maneja Ambiental. É Assistente em Administração no Instituto Federal da Bahia - IFBA, Campus Porto Seguro desde 2011. Foi Coordenadora de Planejamento entre os anos de 2011 a 2014 na instituição e atualmente trabalha com orçamento público no Departamento de Orçamento e Finanças.

\section{KAROLL ANDREA ALFONSO TORRES-CORDIDO}

Possui graduação em Medicina Veterinária - Universidad Nacional de Colombia (2002), mestrado em Zootecnia (2006) e doutorado em Zootecnia (2010) pela Universidade Estadual Paulista Júlio de Mesquita Filho, Campus de Jaboticabal. Foi bolsista PRO-DOC da CAPES e realizou pós-doutorado junto ao Departamento de Zootecnia da FCAV/UNESP (2010-2011). Atualmente trabalha como professora associada junto ao Laboratório de Zootecnia (LZO/CCTA) da Universidade Estadual do Norte Fluminense Darcy Ribeiro- UENF em Campos dos Goytacazes-RJ, Brasil. Áreas de atuação: Avicultura, Nutrição e Produção de Aves, Resíduos da avicultura, Fisiologia Gastrointestinal e 
Metabolismo das Aves Domésticas. Membro PSA (Poultry Science Association). Homenagens: Paraninfo e homenagem dos formandos em Zootecnia da UENF turma 2017/2.

\section{LAIANE FERREIRA DA SILVA}

Graduanda em Tecnologia em Gestão Ambiental pela Universidade Federal de Viçosa - Campus Florestal

\section{LAYLANE PINHEIRO ALVES}

Graduada em Engenharia Florestal e pós-graduada em Engenharia de Segurança do Trabalho, ambas pela Faculdade Pitágoras de Teixeira de Freitas. Atualmente é técnico-administrativa da Divisão de Licenciamento Ambiental, Fiscal de Contratos na Secretaria Municipal de Meio Ambiente de Teixeira de Freitas, e Secretária Executiva do Conselho Municipal de Defesa do Meio Ambiente.

\section{LETÍCIA PASCHOALETTO DIAS}

Formada em Licenciatura em Ciências Biológicas pela UENF (2019) e Gestão Ambiental pela UNOPAR (2016), e é especialista em Gestão, Licenciamento e Auditoria Ambiental também pela UNOPAR (2020). Atualmente é mestranda no Programa de Pós Graduação em Formação em Ciências para Professores (UFRJ) e está envolvida em projetos voltados para Triatomíneos, os Vetores da doença de Chagas, na Fundação Oswaldo Cruz. Tem experiência na área de Meio Ambiente, com ênfase em Gestão e Comunicação Ambiental, Entomologia Geral, Morfologia e Taxonomia de Triatomíneos, além de desenvolver projetos na área da Educação e Promoção da Saúde.

\section{LETÍCIA RODRIGUES DA FONSECA}

Graduada em Ciência da Computação e Administração. Especialista em Gestão de Tecnologias da Informação. Mestra e Doutora em Administração. Professora do Curso de Mestrado Profissional Sustentabilidade em Recursos Hídricos e do Curso de Mestrado Profissional Gestão, Planejamento e Ensino, ambos oferecidos pela Universidade Vale do Rio Verde (UninCor).

\section{LIA MARIS ORTH RITTER ANTIQUEIRA}

Licenciada em Ciências Biológicas (UEPG), Mestre em Gestão do Território (UEPG) e Doutora em Ciências Florestais (Esalq/USP). Professora da Licenciatura em Ciências Biológicas, do Mestrado em Ensino de Ciência e Tecnologia e do Doutorado em Sustentabilidade Ambiental e Urbana na UTFPR Campus Ponta Grossa. Líder do grupo de pesquisa CONEA - Conservação da Natureza e Educação Ambiental, participante da Rede Paranaense de Educação Ambiental e da Rede Internacional de Pesquisa em Desenvolvimento Resiliente ao Clima - RIPEDRC. Editora da Revista Brasileira de Ensino de Ciência e Tecnologia e da Revista Brasileira de Ciências Ambientais.

\section{LIDIANE APARECIDA ALVES}

Licenciada, bacharel mestre e doutora em Geografia pelo Instituto de Geografia da Universidade Federal de Uberlândia (IG/UFU). Sendo o doutorado concluído com estágio (2013-2014) no Instituto de Geografia e Ordenamento do Território da Universidade de Lisboa (ULisboa). Atualmente, professora na Rede Municipal de Educação da Prefeitura Municipal de Uberlândia/MG.

\section{LINCOLN SOUZA LOPES}

Arquiteto e Urbanista Especialista em Projeto, Execução e Desempenho de Fundações e Estruturas, Mestrando em Sustentabilidade em Recursos Hidricos, Docente nos Cursos de Arquitetura e Urbanismo, Engenharia Civil, Agronomia e Engenharia Ambiental.

\section{LORENA LOPES GONÇALVES}


Graduanda em Engenharia Civil pelo Centro Universitário UNA Campus Betim - previsão de formatura para 1ำ semestre de 2021. Cursos: Técnico em Segurança do Trabalho pela Rede de Ensino Genoma (Betim/MG) - 2013 Inglês Básico - Wizard by Pearson (Betim/MG) - 2019 Revit Intermediário - Estúdio BIM. 2020. Experiencia profissional SV Empreeendimentos Imobiliários Estagiária de Engenharia Civil desde Outubro de 2020. Atividades: Acompanhamento de execução de serviços; Leitura e interpretação de Projetos; Elaboração de relatórios; Conferência de trabalhos realizados; Elaboração de diário de obra; Toshiba América do Sul Ltda Unidade Betim -Estagiária de Técnico Segurança do Trabalho. De Maio de 2015 á Maio de 2016 Atividades: Realização de Inspeções de Segurança; Análise de riscos do ambiente e atividades; treinamentos e reuniões; Organização dos documentos do setor.

\section{LUCAS BONAN GOMES}

Doutor em Engenharia de Materiais pelo Programa de Pós-Graduação em Engenharia de Minas, Metalúrgica e de Materiais - PPGE3M - Conceito 7 da Universidade Federal do Rio Grande do Sul UFRGS (2016). Mestre em Engenharia de Processos e Tecnologias pela Universidade de Caxias do Sul - UCS (2012). Tem experiência na área de Engenharia de Materiais, com ênfase em Materiais Cerâmicos, atuando principalmente nos seguintes temas: cerâmica avançada, alumina, cerâmicos refratários, refratários monolíticos, processamento de materiais cerâmicos, densificação e sinterização de materiais cerâmicos, síntese por reação em estado sólido de pós cerâmicos e Física da Matéria Condensada. Tem experiência em Técnicas Avançadas para a Caracterização de Materiais em especial a Difração de Raios X (DRX), ajuste matemático e quantificação de fases pelo Método de Rietveld. Atualmente é Pesquisador da Universidade Federal do Rio Grande do Sul - UFRGS onde é Coordenador Técnico do Laboratório de Difratometria de Raios X (LDRX) do Instituto de Geociências (IGEO) da UFRGS.

\section{LUCIANO MAJOLO}

Aluno do Curso de Bacharelado em Agroecologia, Universidade Estadual da Paraíba (UEPB), Departamento de Agroecologia e Agropecuária.

\section{LUCIDALVA RODRIGUES DE SOUZA NOGUEIRA}

Discente do Programa de Pós-Graduação em Ciências Ambientais - Curso de Doutorado pela Universidade Estadual Paulista - UNESP - Campus em Sorocaba - Período 02/03/2020 a 02/09/2024. Mestre em Ciências Ambientais - Universidade Estadual Paulista (UNESP) Campus Sorocaba/SP. Graduação em Biologia - Faculdade de Ciências e Tecnologia (FTC). Graduação em Pedagogia - Universidade do Estado da Bahia (UNEB). Especialização em Administração Escolar e Ciências Biológicas. Coordenadora Pedagógico de Ciências da Natureza - SME/CETEP/GuanambiBA. Conselheira titular do Meio Ambiente do Estado Bahia - CEPRAM; Conselheira titular - Secretaria de Agricultura e Meio Ambiente de Guanambi/Bahia.

\section{MAISA COMAR PINHOTTI AGUIAR}

Geóloga formada pela UNESP- Campus de Rio Claro (SP) com Doutorado em Geociências e Meio Ambiente pela UNESP- Campus de Rio Claro (SP). Atualmente é professora da Universidade do Estado de Minas Gerais-UEMG, unidade de João Monlevade. 


\section{MARIA LUIZA ANDRADE DE FARIAS AIRES}

Aluna do Curso de Bacharelado em Agroecologia, Universidade Estadual da Paraíba (UEPB), Departamento de Agroecologia e Agropecuária.

\section{MARIA LUIZA DE MELO VIEIRA}

Engenheira Sanitarista e Ambiental (Centro Universitário do Leste de Minas Gerais - UnilesteMG), MBA em Gestão, Perícia e Auditoria Ambiental (Faculdade Mauricio de Nassau - Natal/RN), Engenheira de Segurança do Trabalho (Universidade Potiguar, UnP Natal/RN). Desde 2017 atua na área ambiental na Prefeitura Municipal de Governador Valadares/MG, com a gestão dos resíduos sólidos urbanos, acompanhamento da produção de compostagem de resíduos de poda e enriquecidos com resíduos de horti-fruti, elaboração e execução de novos projetos; presta assistência na área de segurança e saúde do trabalho; ainda possui experiências em consultorias ambientais e de SST e gestão ambiental de empresas e empreendimentos.

\section{MARLON CAMPOS COELHO}

Engenheiro Agrônomo (Universidade Vale do Rio Doce - UNIVALE), Espec. em Gestão Integrada do Território (Inst. BioAtlântica) e Georreferenciamento e Cartografia Digital (UFRN), MBA em Gestão, Perícia e Auditoria Ambiental (Fac. Mauricio de Nassau Natal/RN). Pela profissão possui experiências em projetos nas linhas de pastejo rotacionado para gado de leite, manejo sanitário, controle leiteiro e administração rural; execução e acompanhamento em ações de fomento florestal e recuperação de áreas degradadas do Inst. Estadual de Florestas/MG; fiscalização e licenciamento ambiental e florestal; responsável técnico do Cadastro Ambiental Rural no RN, bem como gestão ambiental de empresas privadas. Desde 2017 serve o Depto. de Meio Ambiente da Prefeitura Municipal de Governador Valadares.

\section{MATEUS LOPES MOREIRA}

Graduando em Engenharia Ambiental e Energias Renováveis,UFRA- Universidade Federal Rural da Amazônia, Capanema-PA, Brasil.

\section{MATHEUS MORAIS DE SOUZA}

Graduando em Tecnologia em Gestão Ambiental pela Universidade Federal de Viçosa - Campus Florestal

\section{MAYARA DOS SANTOS PEREIRA}

Atualmente se graduando em Biomedicina pela Faculdade Integrada Einstein de Limeira. Realizou curdo técnico em mecânica na ETEC Trajano Camargo. No momento atual realiza estágio no laboratório de toxicologia do Instituto de Criminalística. Tem grande interesse na área forense. Participou como autor do artigo Biopirataria no 17o Congresso Nacional de Meio Ambiente de Poços de Caldas, realizado no período de 23 e 24 de setembro de 2020 ( $100 \%$ on-line).

\section{MIRIAM ALBARA}

Possui graduação em Engenharia Química pela Fundação Universidade Regional de Blumenau, pósgraduação Lato Sensu a nível de especialização em Engenharia da Qualidade. Atualmente cursa o Mestrado em Engenharia Têxtil na Universidade Federal de Santa Catarina. Tem experiência na área de gestão da qualidade, garantia da qualidade, gestão de processos, gerenciamento de resíduos sólidos e licenciamento ambiental. 


\section{MIRIAN DOSOLINA FUZINATTO}

O autor possui graduação em Engenharia Química pela Pontifícia Universidade Católica do Rio Grande do Sul (1988), especialização em Eng. de Processos Químicos auxiliado por computador, pela Pontifícia Universidade Católica do Rio Grande do Sul (1994) e MBA em Gestão Empresarial pela Fundação Getúlio Vargas, FGV, Brasil (2006). Possuí 25 anos de experiência na área de produção de Cimento. No segundo semestre de 2019 iniciou Mestrado Profissional em Engenharia e Ciências Ambientais, no Instituto Federal de Educação, Ciência e Tecnologia Sul-rio-grandense, Campus Pelotas, atuando na área de pesquisa de extração de sílica de casca de arroz.

\section{OZANA RODRIGUES BORITZA}

Mestre em Administração área de GESTÃO ESTRATÉGICA DAS ORGANIZAÇÕES - Faculdade de Estudos Administrativos -FEAD- Belo Horizonte - Minas Gerais (2013). Pós-graduação em Direito Civil e Direito Processual Civil - pela Faculdade de Rolim de Moura - FAROL (2010). Graduação em direito pela Universidade Federal de Rondônia UNIR (2009). Agente Penitenciário na Secretaria de Estado de Justiça - RO. de 2002 a 2013. Professora da FAROL Faculdade de Rolim de Moura de 2011 a 2013, nos Cursos de Ciências Contábeis: com as disciplinas de Direito Comercial, Instituição do Direito Público e Privado e Direito do Trabalho; Administração de Empresas: nas disciplinas de Direito Comercial, Instituição do Direito Público e Privado; Direito: na disciplina de Teoria Geral do Estado, Direito Civil Parte Geral, Direito Civil Obrigações II Contratos, Teoria Geral do Processo. Professora do Curso de Direito da Universidade Federal de Rondônia - UNIR- Campus de Cacoal, ja ministrou as disciplinas de Direito Processual Penal II, Direito Processual Penal III. É titular das diciplinas de Direito Penal I Parte Geral, Direito Penal III Parte Especial, Direito Penal IV Parte Especial.

\section{PAULA IRIGON DE IRIGON}

Pesquisadora e Professora do Instituto Federal Sul-Rio-Grandense de Ciência e Tecnologia, onde desenvolve pesquisas na área de extração de sílica a partir de resíduos industriais, tais como sucata de vidro, cinza de casca de arroz e cinza de carvão. Tese de doutorado na área de Engenharia de Materiais (PPGE3M/UFRGS), sobre a viabilidade de extração de nano sílica a partir de cinza pesada de carvão mineral.

\section{PEDRO CASSUCE BRANDÃO}

Graduando em Zootecnia pela Universidade Estadual do Norte Fluminense Darcy Ribeiro - UENF em Campos dos Goytacazes, RJ

\section{PEDRO JOSÉ SANCHES FILHO}

O autor possui graduação em Licenciatura Plena Em Química pela Universidade Tecnológica Federal do Paraná (1988), graduação em Farmácia pela Universidade Católica de Pelotas (1988), mestrado em Química pela Universidade Federal do Rio Grande do Sul (1997) e doutorado em Química pela Universidade Federal do Rio Grande do Sul/Universidade de Córdoba -Espanha (2002) e pós doutorado pela Universidade Nova de Lisboa(2007). Atualmente é professor e Pesquisador do Instituto Federal de Educação, Ciência e Tecnologia Sul-rio-grandense, líder do Grupo de Pesquisa em Contaminantes Ambientais. Tem desenvolvido projetos envolvendo análise de traços em diferentes matrizes ambientais e aproveitamento de resíduos agroindustriais através da termoconversão em produtos com maior valor agregado.

\section{RAFAEL TEIXEIRA COELHO}

Engenheiro Agrônomo pela Universidade Vale do Rio Doce - UNIVALE (Governador Valadares/MG), Espec. em Georreferenciamento de Imóveis Rurais e Levantamentos Georreferenciados pela Faculdade de Engenharia de Minas Gerais - FEAMIG (Belo Horizonte/MG), cursa Direito também pela UNIVALE. Servidor público desde 2014 da Prefeitura Municipal de Governador Valadares, atuando na profissão com atividades de plantios e revitalizações de praças; supervisão das 
atividades do viveiro municipal e acompanhamento de atividades de poda e corte de árvores na área urbana do município; acompanhamento da produção de compostagem de resíduos de poda e enriquecidos com resíduos de horti-fruti; e elaboração de estudos técnicos relativos as atividades desenvolvidas pelo setor.

\section{RAQUEL VIANA QUINELATO}

Mestranda em Ciências e Tecnologias Ambientais pela Universidade Federal do Sul da Bahia (UFSB). Pós Graduada em Gestão, Licenciamento e Auditoria Ambiental (ANHANGUERA). Engenheira Sanitária e Ambiental pelo Instituto Federal de Educação, Ciência e Tecnologia do Espírito Santo (IFBA).Tem experiência na área de monitoramento ambiental, com ênfase em monitoramento da qualidade da água.

\section{RICARDO ANTONIO FRANCISCO MACHADO}

Possui graduação e mestrado em Engenharia Química pela Universidade Federal de Santa Catarina, doutorado em Engenharia Química pela Universidade Federal do Rio de Janeiro, pós-doutoramento industrial na empresa Termotécnica Ltda e pós-doutoramento na Universidade de Bayreuth Alemanha pelo Programa CAPES de Estágio Sênior no Exterior. Atua nas áreas de Processos Industriais da Engenharia Química, em pesquisa aplicada, desenvolvimento e ensino.

\section{RICARDO CUNHA DE OLIVEIRA}

Graduando no curso de bacharelado em Biomedicina pela Universidade do Estado do Pará (UEPA). É membro do Centro Acadêmico de Biomedicina Evandro Chagas (CABEC) da Universidade do Estado do Pará, coordenador do eixo de comunicação e marketing. Tem experiência na área de Morfologia Humana, atua como ligante na liga de Anatomia Humana (LAAHP) vinculada ao instituto de ciências biológicas da universidade federal do pará (ICB - UFPA) com foco em ensino, pesquisa e extensão, assim como a criação peças anatômicas a partir da tecnologia 3D para o laboratório de Anatomia Humana (ICB). Faz estágio voluntário no Laboratório de Pesquisas em Estresse Oxidativo (LAPEO), assim como no Laboratório de Virologia (LabVir), sendo ambos do Instituto de Ciências Biológicas (ICB) da Universidade Federal do Pará (UFPA), também atuou no Instituto Médico Legal (IML) estabelecido no Centro de Perícias Científicas Renato Chaves (CPCRC). Tem interesse nas áreas de genética, bioquímica, virologia, medicina forense, microbiologia e estética.

\section{RICARDO SCOLES}

Biólogo (Universitat de Barcelona, Espanha). Doutor em Biologia (Instituto Nacional de Pesquisas da Amazônia, Brasil). Professor da Universidade Federal do Oestedo Pará, Brasil.

\section{RITA DE CÁSSIA SIQUEIRA CURTO VALLE}

Possui graduação em Engenharia de Alimentos, mestrado e doutorado em Engenharia Química pela Universidade Federal de Santa Catarina e pós doutorado na Universidad de Granada (Espanha). Atualmente é professora do Departamento de Engenharia Têxtil da Universidade Federal de Santa Catarina - Campus de Blumenau, e do programa de Pós-graduação em Engenharia Têxtil da UFSC. Tem experiência na área de Engenharia Química, Engenharia de Alimentos e Engenharia Têxtil com ênfase em processos bioquímicos e surfactantes atuando principalmente, em planejamento estatístico experimental e otimização de processos.

\section{SHIRLEYDE ALVES DOS SANTOS}

Prof. Me. da Universidade Estadual da Paraíba (UEPB), Departamento de Agroecologia e Agropecuária. 


\section{SUSAN ARAGÓN}

Bióloga (Universidad Nacional de San Antonio Abad del Cusco, Peru). Doutora em Geografia (Clark University, Estados Unidos). Pós-doutoranda do PPGRN da Universidade Federal do Oeste do Pará, Brasil.

\section{THAIS GLEICE MARTINS BRAGA}

Engenharia Ambiental pela Universidade Federal Rural da Amazônia (2014), mestrado em Ciências Ambientais pela Universidade Federal do Pará (2016) e doutorado em Doutorado em Biodiversidade e Biotecnologia da Rede BIONORTE pela Universidade Federal do Pará (2019). Atualmente é docente adjunto da Universidade Federal Rural da Amazônia. Tem experiência na área de Geociências, com ênfase em Geociências, atuando principalmente nos seguintes temas: biodiversidade, engenharia ambiental, impacto ambiental, monitoramento ambiental e territorialidade humana, Líder do grupo de pesquisa GECTAM - Grupo de pesquisa em engenharia, ciência e tecnologia da Amazônia, Pesquisadora, avaliadora de periódicos, e membro de editorial técnico - cientifico de fomento a pesquisa e inovação tecnológica.

\section{THIAGO JOSÉ PIMENTA ALVES}

Graduado em engenharia agronômica, atuou como coordenador de campo e mobilizador social em obras de Recuperação Hidroambiental na Bacia do Rio São Francisco. Atualmente exerce a função de Engenheiro Agronômo, atuando com agente de ATER no empreendimento Projeto Hidroagrícola Jequitaí I. Pós Graduação em Recursos Hídricos e Ambientais pela UFMG e Mestrando em Sustentabilidade em Recursos Hídricos pela UNINCOR.

\section{TROY PATRICK BELDINI}

Doutor em Solos e Nutrição de Plantas (Auburn University, Estados Unidos). Professor da Universidade Federal do Oeste do Pará, Brasil).

\section{VICTOR JOSÉ DOS SANTOS BALDAN}

Doutor pelo Instituto de Arquitetura e Urbanismo de São Carlos da Universidade de São Paulo (IAU/USP), na área de Arquitetura, Urbanismo e Tecnologia, e integrante do grupo de pesquisa EcoMat nessa mesma instituição. Integra também, o Núcleo de Pesquisas em Resíduos - NEPER, do Departamento de Hidráulica e Saneamento da Escola de Engenharia de São Carlos (EESC / USP). Atua nas áreas de Engenharia Civil e Arquitetura, Urbanismo e Tecnologia, pesquisando nos seguintes temas: desenvolvimento de compósitos poliméricos e seu desempenho no ambiente construído, gestão e gerenciamento de resíduos industriais e de construção e demolição (RCD), sustentabilidade na construção civil, desenvolvimento de materiais de construção a partir da utilização de RCD e levantamento de emissões de CO2 na fabricação e utilização de materiais de construção civil. É coordenador e docente do curso de Engenharia Civil das Faculdades Integradas Einstein de Limeira, desde o segundo semestre de 2017.

\section{WILTON SILVA DE SOUZA}

Formado em técnico em química, pela Escola Técnica Alto Média São Francisco (FUNAM). Atualmente graduando Biomedicina pela Faculdades Integradas Einstein de Limeira (FIEL). Participou como autor do artigo Biopirataria no 17을 Congresso Nacional de Meio Ambiente de Poços de Caldas, realizado no período de 23 e 24 de setembro de 2020 ( $100 \%$ on-line) .

\section{YURI FERNANDO DUBBERN}

Estudante de Engenharia Elétrica, cursando décimo semestre na instituição FIEL (Faculdade Integradas Einstein de Limeira). 


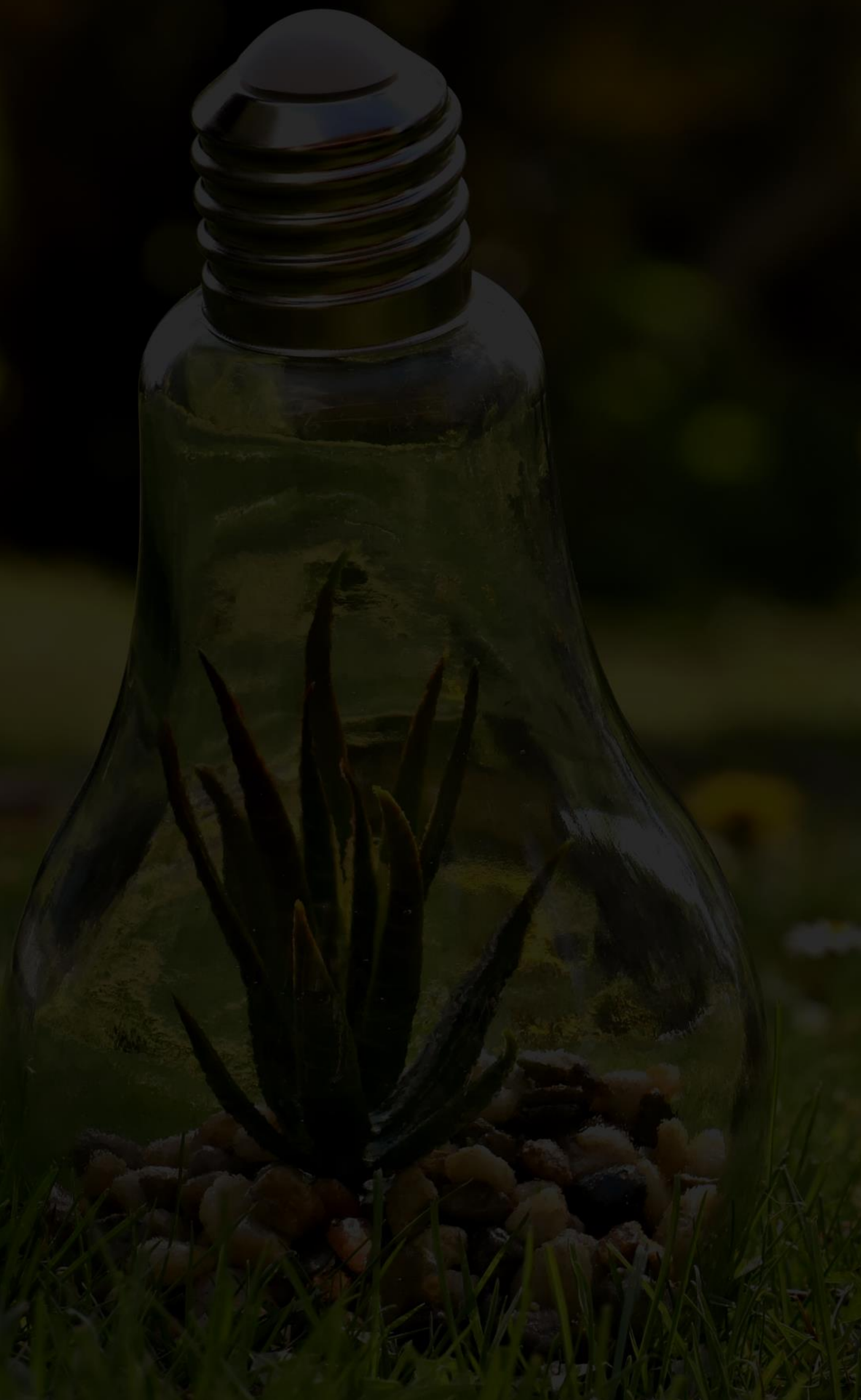

